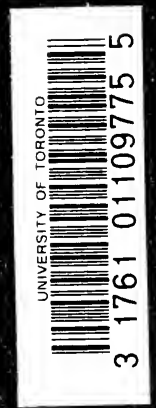
20 4054020 1.7.4.

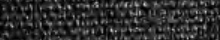
$20,7 \times 0$.

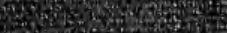

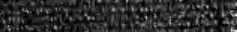
3.

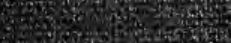
X5. 2070 .

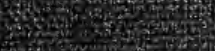
Howes

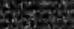

n+

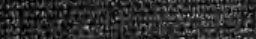
(t) +

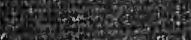

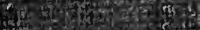
Wh

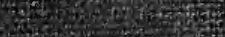
fin 20 6. (1)

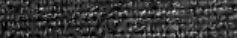
(2)

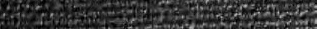
40. 6. Whit

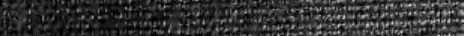

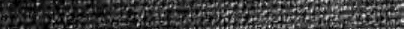

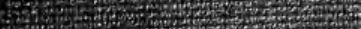

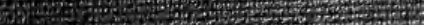

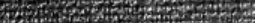
Wor.

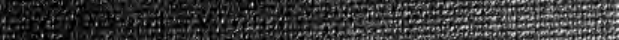

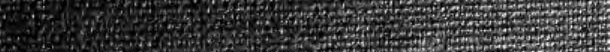

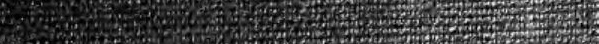
Hat

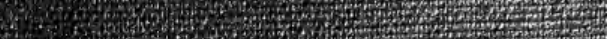

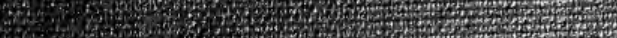
Ho

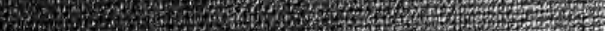

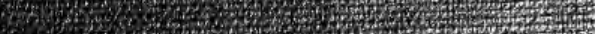
1.5. 970 (1)

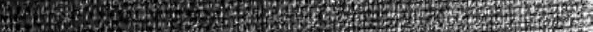

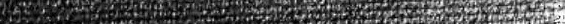







TRUBNER'S

\section{ORIENTAL SERIES}




\section{TRUBNER'S ORIENTAL SERIES}

\section{POPULAR RE-ISSUE AT A UNIFORM PRICE}

Demy 8vo, dark green cloth, gilt.

ALBERUNI: India. An Account of the Religion, Philosophy, Literature, Geography, Chronology, Astronomy, Customs, Laws, and Astrology of India, about A.D. rozo. BY DR. EDWARD C. SACHAU.

ARNOLD (Sir E.): Indian Poetry and Indian Idylls. Containing ' 1 he Indian Song of Songs,' from the Sanskrit of the Gita Govinda of Jayadeva: Tro Books from the 'Iliad of India' (Nahabharata): 'Proverbial Wisdom," trom the Shlokas of the Hitopadesa, and other Oriental Puems.

BARTH (Dr. A.): The Religions of India. Authorised Translation by REv. J. Wood.

BIGANDET (B. P.): Life or Legend of Gaudama, the Buddha of the Burmese; With Annotations, the Ways to Neibban, and Notice on the Phongyies or Burmese Mlonks.

BEAL (Prof. S.): Life of Hiuen-Tsiang. By the Shamans HWU $\mathrm{L}_{1}$ and YEN.Tsung. With a Preface containing an Account of the Works of I-T sing.

BEAL (Prof. S.): Si-Yu-Ki : Buddhist Records of the Western World. Translated from the Chinese of Hiuen-Tsiang.

BOULTING (Dr. W.): Four Pilgrims: I., Hiuen Tsiang; II., Sawult; III., Nohammed ibn abd Allah; IV., Ludovico Varthema of Bologna.

COIVELL (Prof. E. B.): Sarya-Darsana-Samgraha; or, Review of the Different Systems of Hindu Philosopby. By Madhava Acharya. Translated by Prof. E. B. Cowell, M.A., and Prof. A. E. Govgr, M.A.

DOIVSON (Prof. J.): Classical Dictionary of Hindu Mythology and Religion, Geography, History, and Llterature.

EDKINS (Dr. J.): Chinese Buddhism: A Volume of Sketches, Historical, and Critical. New and Revised Edition.

ROCKHILL (WV. W.): The Life of the Buddha and the Early Hlstory of his Order. Derived trom Tibetan works in the Bkahhgyur atnd Bstan-ngyur. Followed by notices on the early history of Tibet and Khoten.

H.IUG (Dr. M.): Essays on the Sacred Language, Writings, and Religion of the Parsls.

WEBER (Dr. A.): History of Indian Literature. Translated by Johs MANs, M.A., and THEOdore ZaChakiak. Ph.D. Fourth Edition.

O'LEARY' (De Lacy): Arabic Thought and its Place in History.

Other Volumes to follow.

LONDON

KEGAN PAUL, TRENCH, TRUBNER \& CO., LtD. 
04535

\title{
A SHORT HISTORY OF THE FATIMID KHALIFATE
}

\author{
BY \\ DE LACY O'LEARY, D.D.
}

Lecturer in Aramaic and Syriac, Bristol University Author of "Arabic Thought and its Place in History"

$$
\frac{180514}{15 \cdot 5 \cdot 23}
$$

LONDON :

KEGAN PAUL, TRENCH, TRUBNER \& CO., LTD.

NEW YORK: E. P. DUTTON \& CO. 
Printed in Great Britain by

John Roberts Press Limited, London. 


\section{INTRODUCTORY NOTE}

THE following pages present a brief outline of the history of the Fatimid Khalifs who were ruling in Egypt at the time of the First and Second Crusades. Too often the student of European history gleans his knowledge of the oriental powers with which the West was brought into contact by the Crusades from western Christian writers, who do not fairly or truly describe those powers, and do not set forth clearly the strong and weak points which are so important in interpreting the actual forces with which the Crusaders were brought into contact. These pages are drawn from the Arabic and Persian historians so as to present a picture which, though inaccurate in some points, nevertheless shows the other side not perceived by the historians who wrote the narrative of the Crusades from a western standpoint. Directly, therefore, they supplement the western history, but are still more important in their indirect bearing as an effort has been made to show the rise and development of the Fatimid Khalifate and sect as a rival to the orthodox Abbasid Khalifate of Baghdad, which is most essential to the right understanding of the world into which the Crusaders penetrated, whilst at the same time it shows a curious and important phase of Muslim tendencies which are not without a bearing on the later history of Islam. The present essay does not claim to be an original study in a field hitherto unexplored, but simply aims at bringing together in an accessible form material which will be of service to the student of mediaeval western history and to those who are interested in the development of Islam, and to do so with such comments as will enable it to be co-ordinated with contemporary European history. 



\section{CONTENTS}

CHAP.

PAGE

I The Shi'ites or Schismatics of IsLaM I

II The Isma'ilian Sect • . . . I 2

III The QARmatians . . . . . . 39

IV The Establishment of the Fatimids in North Africa . . . . $55^{\mathrm{I}}$

V The Fatimid Khalifs of Kairawan * 74

VI The Second Fatimid Khalif, Al-QA'im 88

VII The Third Fatimid Khalif, AlMansur .

Vili The Fourth Fatimid Kualif, AlMO`IZZ . . . . . . . $\quad .93<$

iX The Fifth Fatimid Khalif, Al-'Aziz II5

$\mathrm{X}$ The Sixth Fatimid Khalif, Al-Hakm 123 -

Xi The Seventh Fatinid Khalif, Az-

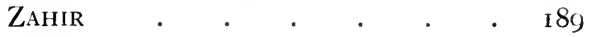

XII The Eighth Fatinid Khalif, Al-

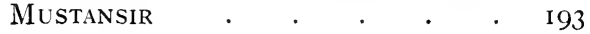

XiII The Ninth Fatimid Khalif, AlMustali . . . . . . . 211

XIV The Tenth Fatimid Khalif. Al-Amir 2 I 8 XV The Eleventh Fatimid Khalif, AlHAFIZ • . . . . . 222

XVi The Twelfth Fatimid Khalif, Az- 
VIII.

CONTENTS

XViI The Thirteenth Fatimid Kalif, Al$\mathrm{FA}^{\prime} \mathrm{IZ}$

233

XVIII The Fatimid Khalifate in its Recation to General History • • 246

xix The Later History of the Isma'ilian SECT

BIBLIOGRAPHY

INDEX

257

262

266 


\section{THE SHI'ITES OR SCHISMATICS OF ISLAM}

ISLAM appears first on the page of history as a purely Arab religion: indeed it is perfectly clear that the Prophet Mohammed, whilst intending it to be the one and only religion of the whole Arab race, did not contemplate its extension to foreign communities. "Throughout the land there shall be no second creed" was the Prophet's message from his death-bed, and this was the guiding principle in the policy of the early Khalifs. The Prophet died in A.H I I, and within the next ten years the Arabs, united under the leadership of his successors, extended their rule over Egypt, Syria, Mesopotamia, and Persia. To a large extent it was merely an accident that this rapid expansion of Arab rule was associated with the rise of Islam. The expanding movement had already commenced before the Prophet's ministry, and was due to purely secular causes to the age long tendency of the Arabs, - as of every race at a similar stage of economic and social development,- to over-spread and plunder the cultured territories in their vicinity. The Arabs were nomadic dwellers in a comparatively unproductive area, and had been gradually pressed back into that area by the development of settled communities of cultivators in the better irrigated land upon its borders. These settled communities evolved an intensive agriculture, and thus achieved great wealth and an advanced state of civilization which was a perpetual temptation to the ruder nomads who, able to move over great distances with considerable rapidity, were always inclined to make plundering incursions into the territories of the prosperous agricultural and city states near at hand. The only restraint on these incursions was the military power of the settled communities which always had as 
its first task the raising of a barrier against the wild men of the desert: whenever the dyke gave way, the flood poured out. In the seventh century A.D. the restraining powers were the Roman Empire and the Kingdom of Persia, and both of these, almost simultaneously, showed a sudden military collapse from which, in the natural course of events they would, no doubt, have recovered after a short interval; but the Arabs poured in at this moment of weakness, just as the Teutonic and other groups of central Europe had broken through the barriers of the western half of the Rornan Empire; and at that moment, in the course of their incursion, they received a new coherence by the rise of the religion of Islam and, by the racial unity thus artificially produced, became more formidable.

In their outspread over Egypt and Vestern Asia the Arabs adopted the policy, partly deduced from the Qur'an and partly based on the tradition of the first Khalif's conduct in Arabia, of uncompromising warfare against all " polytheists," - the creed of Islam was a pure unitarianism, and could contemplate no toleration of polytheism,- - but of accommodation with those possessed of the divine revelation, even in the imperfect and corrupt form known to Christians and Jews. These "People of the Book" were not pressed to embrace Islam, but might remain as tribute-paying subjects of the Muslim rulers, with their own rights very fully secured. In all the conquered lands the progress of the Muslim religion was very gradual, and in all of them Christian and Jewish communities have maintained an independent continuous existence to the present day. Yet for all this there were very many conversions to the religion of the ruling race, and these were so numerous that within the first century of the Hijra the Arabs themselves were in a numerical minority in the Church of Islam. The alien converts, socially and intellectually developed in the culture of the Hellenistic world or of semi-Hellenistic Persia, were very far in advance of the ruling Arabs who were little better than half savages at the commencement of their career of conquest : and the unexpected inclusion of this more cultured element acted as a leaven in the Islamic community, and forced it to a rapid and somewhat violent evolution. It is wonderful that Islam had 
sufficient vigour and elasticity to be able to absorb such fresh elements and phases of thought, but that elasticity had its limits, and at a very early date sects began to form whose members the orthodox felt themselves unable to recognise as fellow Muslims.

These early sects which were generally regarded as heretical were, in most cases, reproductions of older preIslamic Persian and Mesopotamian religious systems, with a thin veneer of Muslim doctrine, and, in the second century of the Hijra, when they became most prominent, they were strongly tinctured with Hellenistic philosophical speculations which had already exercised a potent influence in Mesopotamia and Persia. In theory these sects were "legitimist" in their adherence to the principle of hereditary descent. Orthodox Islam accepted as a constitutional principle the leadership of an elected khalif or " successor," a natural development of the tribal chieftainship familiar to the preIslamic Arabs. Amongst them the chief was elected in a tribal council, in which great weight was given to the tried warriors and aged men of experience, but in which all had a voice, and choice was made on what we should describe as democratic lines, and this remained the practice in the earlier age of Islam. Such a constitutional theory was no great novelty to those who had lived under the Roman Empire, but was entirely repugnant to those educated in Persian ideas, and who had learned to regard the kingship as hereditary in the sense that the semi-divine kingly soul passed by transmigration at the death of one sovereign to the body of his divinely appointed successor. This had been the Persian belief with regard to the Sasanid kings, and the Persians fully accepted Yazdegird, the last of these, as a re-incarnation of the princes of the semi-mythical Kayani dynasty to which they attributed their racial origin and their culture. Yazdegird died in A.H. 31 (=A.D. 652), and his death terminated the male line of the Persian royal family, but it was generally believed that his daughter, Shahr-banu, was married to Husayn, the son of the fourth Khalif 'Ali, so that in his descendants by this Persian princess the claims of Islam and of the ancient Persian deified kings were combined. Historically the evidence for this marriage 
seems to be questionable, but it is commonly accepted as an article of faith by the Persian Shi'ites.

At a quite early date the house of 'Ali began to receive the devoted adherence of the Persian converts. That 'Ali himself had been prominent as a champion of the rights of alien converts to equality in the brotherhood of Islam, and still more his harsh treatment by Mu'awiya, the founder of the 'Umayyad dynasty, caused his name to serve as a rallying point for all those who were disaffected towards the offiical Khalifate. It is now the general Shi'ite belief that 'Ali, the cousin and son-in-law of the Prophet, was his chief companion and chosen successor, the three preceding Khalifs being no more than usurpers who had kept him out of his just rights and whose wrong doing he had borne with exemplary patience. 'Ali himself does not seem to have taken so pronounced a view, but he certainly regarded himself as injured by his exclusion from the Khalifate. It is not true to say with Muir (Caliphate, p. 30I), that the idea of a divine Imamate or "leadership " was entirely the invention of later times because, as early as A.H. 32, in the reign of ' $U$ 'thman, the Jewish convert 'Abdu b. Saba of Yemen,-a district which had been conquered by the Persian king Nushirwan, and settled by Persians for nearly a century before the coming of Islam, and so thoroughly impregnated with Persian ideas, - preached the divine right of 'Ali. This view he maintained afterwards when 'Ali was Khalif, in spite of 'Ali's own disapproval, and at 'Ali's murder in A.H. 4O, he reiterated it in a more pronounced form : the martyred Khalif's soul, he said, was in the clouds, his voice was heard in the thunder, his presence was revealed in the lightning: in due course he would cescend to eartin again, and meanwhile his spirit, a divine emanation, was passed on by re-birth to the 1 mams his successors.

Certainly the tragedy of Kerbela, which centred in the pathetic sufferings and death of 'Ali's son, Husayn, as he was on his way to claim the Khalifate, produced a tremendous wave of pro- Alid feeling: indeed a popular martyr was the one thing needed to raise devotion to the house of 'Ali to the level of an emotional religion, though many, no doubt, supported the 'Alid claims simply because they formed the most convenient 
pretext for opposing the official Khalifate, and yet remaining outwardly within the fold of Islam.

After the death of Husayn there were three different lines of 'Alids which competed for the allegiance of the legitimist faction, those descended from (i.) Hasan, and (ii.) Husayn, the two sons of 'Ali by his wife Fatima, the daughter of the Prophet, and both therefore representing the next of kin to the Prophet who left no son, and (iii.) the house of Muhammad, the son of 'Ali, by another wife known as the Hanifite. Of these three we may disregard the descendants of (i.) Hasan, who ultimately migrated to Maghrab (Morocco), and became the progenitors of the Idrisid dynasty and of the Sharifs of Morocco: they formed a very moderate branch of the Shi'ite faction, adopted many practices of the orthodox or Sunni party, and had no part in the peculiarly Persian developments of the Asiatic Shi'ites. The first 'Alid faction to become prominent was (iii.) the partisans of Muhammad, the son of the Hanifite, who were formed into a society by Kaysan, a freedman of 'Ali, for the purpose of avenging Hasan and Husayn. They recognised a succession of four Imams or valid commanders, 'Ali, Hasan, Husayn, and Muhammad, the son of the Hanifite, and maintained that, at Husayn's death, Muhammad became de jure the Khalif and the divinely appointed head of the Church of Islam. Muhammad himself entirely disowned these partisans, but that was a detail to which they paid no attention. At Muhammad's death in A.H. 8I this party, "the Kaysanites" as they were called, recognised his son Abu Hashim as the fifth Imam until A.H. 98, when he died childless after bequeathing his claims to Muhammad b. 'Ali b. 'Abdullah (d. A.H. I26), who was not of the house of 'Ali at all, and who became the founder of the 'Abbasid dynasty which obtained the Khalifate in A.H. I32. It was under Abu Hashim that the party, now changed in name from Kaysanites to Hashimites, became an admirably organised conspiracy which contributed more than anything else to the overthrow of the "Umayyad Khalifs: Throughout the Muslim dominions there was deep and everincreasing dissatisfaction with the 'Umayyads, who represented an arrogant parvenu Arab aristocracy, ruling over races who enjoyed an older and richer 
culture, and were by no means effete. The Hashimites seized. hold of this discontent and sent out their missionaries ( $d a^{\prime} i$, plur. $\left.d u^{\prime} a t\right)$ in all directions disguised as merchants and pilgrims who relied upon private conversations and informal intercourse rather than public preaching, and thus began that unostentatious but effective propaganda, which has ever since been the chief missionary method of Islam. Hashimite teaching centered in the doctrines of tawakkuf or the theory of a divinely appointed Imam, who alone was the rightful Commander of the faithful and their authoritative teacher, of hulul or the incarnation of the Divine Spirit in the Imam, and of tenasukhu l-Arwah or the transmigration of that Spirit from each Imam to his valid successor, doctrines alien to Islam proper. With the death of the Abu Hashim this party passed over to the service of the 'Abbasids to whom it was a source of great strength, and at their accession to the Khalifate it ceased to exist as a sect.

The most important sect, or group of sects, of the Shitites was (ii.) the faction which recognised Husayn as the third Imam, and his son, 'Ali Zayn al-Abidin (d. 94 A.H.) as his successor, the son of the Imam and of the royal princess of Persia. But at al-Abidin's death this party split into two, some following his son Zayd (d. 121), others his son Muhammad a1-Bakir (d. II3). The former or Zaydite party established itself for a considerable period in North Persia, and still maintains itself in South Arabia. Zayd himself was the friend and pupil of the Mu'tazilite or rationalist leader Wasil ibn 'Ata, and the Zaydites have generally been regarded as more or less free thinkers. The majority of the Shi'ites, however, recognised Muhammad al-Bakir as the fifth Imam, and after his death Ja'far as-Sadiq (d. I4S) as the sixth, though here again there was a schism, some regarding Abu Mansur, another son of Muhammad al-Bakir, as the sixth Imam. Abu Mansur seems to have been one of the first 'Alids to endorse the divine rights claimed for them by their followers, and did so in an extreme form, asserting that he had ascended to heaven and obtained supernatural illumination. At this time all the extremer Shi'ites regarded the Imam as an incarnation of the Divine Spirit passed on from 'Ali, and many believed 
that 'Ali was the true prophet of God whose office had been fraudulently intercepted by Muhammad.

The Mansuris, however, were a minor sect, the majority of the Shi'ites followed Ja'far who was Imam at the time of the 'Abbasid revolution. He was one of those who were deeply influenced by the traditions of Hellenistic philosophy and science, and was the author of works on chemistry, augury, and omens: he is usually credited with being the founder, or at least the chief exponent, of what are known as batinite views, that is to say, the allegorical interpretation of the Qur'an as having an esoteric meaning, which can only be learned from the Imam who is illuminated by divine wisdom, and who alone is able to reveal its true sense. The inner meaning thus revealed was usually a more or less imperfect reproduction of Aristotelian doctrine as it had been handed down by the Syriac writers. Like his brother, Abu Mansur Ja'far fully endorsed the doctrine of a divine Imamate and the transmigration of the Divine Spirit, then tabernacled in himself, and it seems probable that Van Vloten (Recherches sur la domination arabe, I894, pp. 44-45) is right in suggesting that the general promulgation of these beliefs amongst the Shi'ites was largely due to the labours of the Hashimite missionaries.

The contemporary establishment of the 'Abbasids made a far-reaching change in the conditions of Islam. The Arabs began to take a secondary place, and Persian influences became predominant. In 135 the noble Persian family of the Barmecides began to furnish wasirs or Prime Ministers to the Khalifate, and controlled its policy for a period of fifty-four years. Nearly all important offices were given to Persians, and a distinct anti-Arab party was formed, known as the Shu'ubiyya, which produced a prolific controversial literature which expressed the hatred stored up under generations of 'Umayyad misrule: the Arab was held up to derision, his pretensions to aristocratic descent were contrasted with the much more ancient genealogies of the Persian nobles, and he was portrayed as little better than an illiterate savage. In literature, in science, in Muslim jurisprudence and theology, and even in the scientific treatment of Arabic grammar, the Persians altogether surpassed the Arabs, so that we must be 
careful not to talk of Arab philosophy, Arab science, etc., in the history of Muslim civilization, but always of Arabic philosophy, etc., remembering that it was not the science and philosophy of the Arabs, but that of the Arabic speaking people, amongst whom only a small minority were actually of Arab race: and this applies to the "golden age" of Arabic literature (A.H. $13^{2-232}$ ). On the other hand it must be remembered that, indirectly and unintentionally, the 'Umayyads had helped towards this result. It was under their rule that the Arabic language had been introduced into the public administration, and in due course replaced Greek and Persian in all public business, so that it became the common speech of all Mestern Asia, or at least a common medium of intercourse between those who used various languages in their private life, and thus the brilliant intellectual and literary renascence was rendered possible by a wide exchange of thought.

IVe may rightly refer to this period as a renascence, for it meant quickening into new and other life the embers of the later Hellenistic culture, and especially of the Aristotelian philosophy and medical and natural science, which had never quite died away in IVestern Asia, but had been checked by its passage into Syriacspeaking and Persian-speaking communities, amongst whom the language in which the original authorities were written was only imperfectly known. Thus Hellenism suffered a phase of provincialism, which came to an end when Arabic appeared as a more or less cosmopolitan language, and thought began to be exchanged by different races and social groups. Lnder the early 'Ibbasids, and especially under the Khalif al-Ma'mum (A.H. I $98-2$ I8), there was a vast amount of translation from Greek into Arabic until the greater part of Aristotle, of the neo-Platonic commentators on Aristotle, of Galen, some parts of Plato, and other material, were freely accessible to the Muslim world: whilst at the same time translations were made from Indian writers on mathematics, medicine, and astronomy, some directly from the Sanskrit, and others from old Persian versions.

As a result the philosophical speculations of the Greeks began to act as a solvent upon Islamic theology, and from this doctrinal discussions and con- 
troversies arose which, on the one side, produced a series of rationalistic heresies, and on the other side laid the foundations of an orthodox Muslim scholasticism. Long before this Hellenistic influences had permeated Persia and Mesopotamia, and these now revived and resulted in a philosophical presentation of religion which, under the veil of allegorical explanations of the Qur'an, was really undermining orthodox doctrine, and heading towards either pantheism or simple agnosticism. With these tendencies the proPersian party was particularly associated. The Khalifs who, in spite of Arab birth, were most devoted tc Persian ideas, largely because the Persians were subtle courtiers and were the champions of absolutism, were amongst those most ardent in promoting the study of Greek philosophy; and the Imams, such as Ja'far and his brother Zayd, were even more devotedly attached to this type of philosophical speculation which was acting as a powerful solvent on the traditional beliefs of orthodox Islam.

At Ja'far's death another schism took place, indeed the perpetual sub-division into new sects has always been a salient characteristic of the Shi'iva. Ja'far had nominated his son Isma'il as his successor, but afterwards disinherited him because he had been found in a state of intoxication and chose as heir his second son, Musa al-Cazam. There were some, however, who still adhered to Isma'il, and refused to admit that his father had power to transfer the divinely ordained succession at will; they asserted indeed that the son's drunkenness was itself a sign of his superior illumination as showing that he knew that the ritual laws of the Qur'an were not to be taken literally, but had an esoteric meaning which did not appear on the surface. Musa, the seventh Imam as generally reckoned, and his son, 'Ali ar-Rida (p. 202), the "two patient ones," suffered harsh treatment at the hands of the contemporary Abbasid rulers; they were brought from Madina by Harun ar-Rashid so as to be under the observation of the court, and in 148 Musa was poisoned by the wazir Ibn Khalid. His son 'Ali married the daughter of the Khalif Ma'mun, and was intended to be the heir to the throne. But Ma'mun very nearly provoked civil war by his strong Shi'ite sympathies, and when he per- 
ceived how dangerous a storm the projected accession of 'Ali was beginning to arouse, he extricated himself from the difficulty by procuring the Imam's death. 'Ali al-Qazim was usually reckoned as the eighth Imam, the ninth was Muhammad al-Jawad (d. 220), the tenth 'Ali al-Hadi (d. 254), and the eleventh al-Hasan (d. 260), these two latter being buried at Samarra, which replaced Baghdad as the 'Abbasid capital from A.H. 222 to 279. The town afterwards fell into decay, but has been colonised by Shi'ites, and is one of the places of Shi'ite pilgrimage. The twelfth Imam was Muhammad alMuntazir, who in A.H. 260 " disappeared." The mosque at Samarra is said to cover an underground vault into which he went and was no more seen. The " twelvers," or Ithna "ashariya, who to-day form the main body of the Shi'ites, and whose belief is the official religion of modern Persia, suppose that he is still living, and the place where he is to re-appear when he emerges from concealment is one of the sacred spots visted by the Shi'ites.

But, as we have already noted, some of the Shi'ites did not accept Ja'far's transference of the Imamate from his son Ism'il to his second son Musa, but recognised Isma'il still as heir. Isma'il died in I 45 whilst his father was still alive, leaving a son named Muhammad. Although Isma'il's body was publicly shown before its burial at al-Baki", many persisted in believing that he was not dead, and asserted that he had been seen in Basra after his supposed funeral; others admitted his death, but believed that his Imamate had passed to his son Muhammad; others again believed that his soul had migrated to Muhammad, so that they were in reality one person. These adherents of Isma'il, or of his son Muhammad, or of Isma'il-Muhammad, formed the sect known as the Isma'ilians or the Sab'iya, i.e., " seveners," accepting the six Imams to Ja'far as-Sadiq, and adding his son or grandson as the seventh and last.

These "seveners" seem to have been a comparatively minor sect of the extremer Shi'ites. Some members of the sect are still to be found in the neighbourhood of Bombay and Surat. But, about $25^{\circ}$ this comparatively obscure sect was taken in hand and organised by a singularly able leader, and became for a time one of the most powerful forces in Islam. 


\section{GENEALOGY OF THE FAMILY OF 'ALI}

(I) 'Ali d. 4 I.

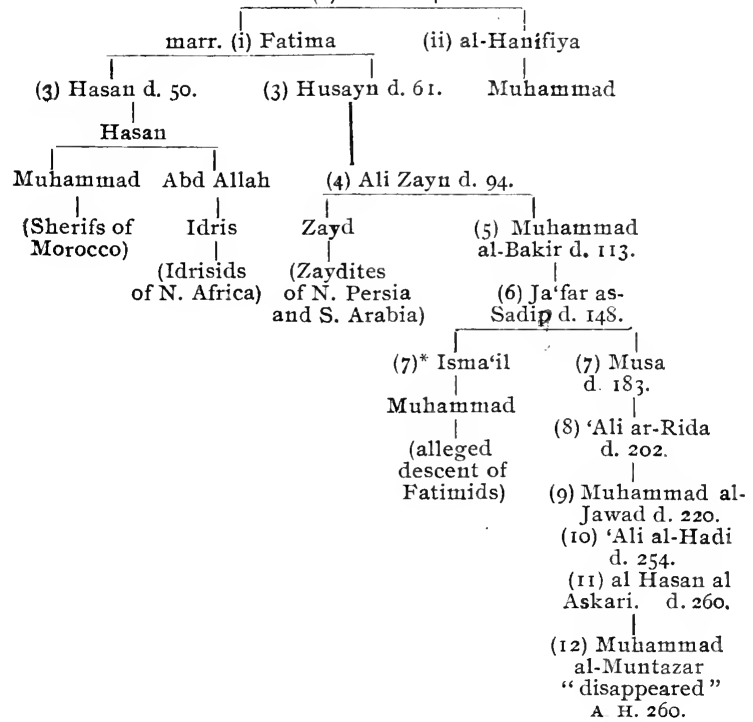




\section{THE ISMA'ILIAN SECT}

From the beginning the neo-Isma'ilian sect showed all the characteristics of the ultra Shi'ite bodies : it accepted the alim l-batin, or the principle of allegorical interpretation which is especially associated with Ja'far asSadiq, the doctrine of incarnation, and of the transmigration of the Imam's soul. But underneath all this, borrowed from current Shi'ite ideas, it had a strong element of agnosticism, a heritage of the philosophical ideas borrowed from Greek scientists, and developed in certain directions by the Mu'tazilites. As organised by its leader, whose name was Abdullah b. Maymun, it was arranged in seven grades to which members were admitted by successive initiations, and which diverged more and more from orthodox Islam until its final and highest stages were simply agnostic. According to Stanley Lane-Poole " in its inner essence Shi'ism, the religion of the Fatimids is not Mohammedanism at all. It merely took advantage of an old schism in Islam to graft upon it a totally new and largely political movement" (Lane-Poole: Story of Cairo, Lond., 1906, p. II3). In this passage "Shi"ism" is taken as denoting the sect of the " Seveners," and the "political movement" is simply disaffection towards the Khalifate. Similarly Prof. Nicholson considers that "Filled with a fierce contempt of the Arabs and with a free-thinker's contempt for Islam, Abdullah b. Maymun conceived the idea of a vast secret society which should be all things to all men, and which, by playing on the strongest passions and tempting the inmost weaknesses of human nature, should unite malcontents of every description in a conspiracy to overthrow the existing régime" (Nicholson: Literary History of the Arabs, pp. 271-272). 
Undoubtedly the ideas involved in the Isma'ilian doctrines were totally subversive of the teachings of Islam, but so were those of the " philosophers," and in exactly the same way. The views of Ibn Tufayl (d. 531 A.H.) and of Ibn Rushd (Averroes, d. 595 A.H.) were purely Aristotelian in basis, and on this foundation was built up an agnostic-pantheistic superstructure. Ibn Tufayl particularly makes it quite clear that his teaching is not consistent with the Qur'an which he treats as setting forth a system of doctrines and ritual precepts suitable for the unlearned who ought not to be disturbed in their simple faith, but quite inadequate for the satisfaction of the more intelligent: the mysteries of the universe, revealed through Aristotle and his followers, furnish a sounder religion, but it is expedient that this be reserved for the enlightened and not divulged to the iliterate who are unable to appreciate or understand its bearing. Such teaching is subversive of orthodox Islam, and consciously so: in the case of 'Abdullah it may, perhaps, be described as a conspiracy against religion. In one sense it was the final product of the rationalism of the Mu'tazilites.

Admittedly the Isma'iliya worked as a political conspiracy against the 'Abbasids, but this was true of every Shi'ite sect : the 'Abbasids had used the Shi'ites in seating themselves on the throne, and then discarded them. Still it seems that we have no reason to question the perfect sincerity of the Isma'ilians in their agnostic principles: those principles were the product of the solvent influence of Greek philosophy upon the religion of Islam: Islamic thought was too simple and primitive to be able to adapt itself to that philosophy in its entirety, hence some such position as that of Ibn Tufayl, or of Ibn Rushd, or of the Isma'ilians, was inevitable. It was equally a necessary result of the time and circumstances that these rationalists tended towards the Shi'ites. In spite of weird superstitions, especially ، current in Khurasan, the Shi ites represent the Muslim element most kindly disposed towards freedom of thought. This seems a bold statement to those familiar with Shi'ites of the present day, but it must be noted that the Shi'ites whom the European most frequently meets are either the devotees who have settled in places like Samarra, or those who seem to be more exclusive 
than the orthodox Muslims, chiefly because they have as yet had much less intercourse with foreigners. In 2-3rd cent. Islam it was the Shi'ite princes who invariably did their best to foster philosophical and scientific research, whilst, after A.H. 232, the orthodox party, as it gets in the ascendent, becomes distinctly reactionary, and tends to repressive persecution.

The most difficult task for us is to appreciate the strong appeal which the doctrines of incarnation and transmigration made to the Persian and Mesopotamian mind. Both these doctrines had figured prominently in pre-Islamic religions in Western Asia; and both recur in most religious movements from the coming of Islam to the present day in that particular area. IVe may note a few instances to illustrate this, and show incidentally the strong attraction these doctrines had for the Persian mind.

Abu Muslim was the general who more than any other helped to seat the 'Abbasids on the throne, and suffered death at the hands of the first 'Abbasid Khalif, who was jealous, - with good cause, it would appear,of his excessive power. But Abu Muslim had exercised an extraordinary influence over men during life, and was treated as a quasi-divine hero after death, his admirers regarding him as not really dead but as having passed into " concealment," some other having been miraculously substituted for him at the moment of execution. This resembles the theory which the preIslamic Persian teacher Mani held as to Christ. Mani fully accepted Christ as a religious teacher, side by side with Zoroaster and Buddha, but he could not admit the reality of his death, for a material body capable of death was in his view unworthy of one purely good. He supposed, therefore, that at the crucifixion Simon of Cyrene was at the last moment substituted for Christ, and this Persian idea has actually obtained a place in the Qur'an (cf. Sura 4, i 56 ).

Not long after Abu Muslim we hear of a pseudoprophet named Bih-afaridh, a Zoroastrian who had travelled in the far East, and afterwards accepted Islam at the hands of two du'at who were preaching the cult of Abu Muslim. Very little is known of his teaching, but he certainly maintained the doctrine that the Imam is an incarnation of the Deity, and seems to have 
attached a particularly sacred signification to the numeral seven. This superstitious reverence for particular numbers was a common feature in the pre-Islamic religions of Mesopotamia, and we shall meet it again in the doctrines of the Isma'ilians.

Another sect, of similarly pre-Islamic origin, was that known as the Rawandiyya from its origin at Rawand near Isfahan. Its members were king-worshippers in the old Persian sense, and a body of them travelled to Hashimiyya, where the Khalifs then had their residence, and tried to acclaim the Khalif alMansur as a god. He not only rejected the proffered adoration, but cast the leaders into prison. This was followed by an attempt to attack the palace, the Rawandis considering that, as the prince had disclaimed deity, he could be no valid ruler. For some centuries the sect, strongly disaffected towards the Khalifate, lingered on in Persia and had many sympathisers.

Under the next Khalif al-Mahdi, came the still more serious rebellion of al-Muqanna", the "veiled prophet of Khurasan," who asserted his own deity. He was killed in A.H. 169, but his followers, as usual, believed that he had not really suffered in person, but had passed into concealment and would in due course return again : they continued to form a distinct sect for some three hundred years.

Another pseudo-prophet of the same type was Babak al-Khurrami, who was executed in A.H. 222 or 223. He also declared himself to be an incarnation of the Divine Spirit, and asserted that the soul within him had already dwelt in his master Jawidan.

We might continue to extend the series very considerably by enumerating the various prophets and sects which reproduce these same general characteristics. The latest example occurs in the Babi movement, which still flourishes and has many converts in this country and in America. The first teacher of the Babists, Mirza 'Ali Muhammad (A.D. I820-I 85I) claimed only to be a Mahdi or fore-runner of One who was to come, but his successor, Mirza Husayn 'Ali, declared himself to be the expected One, the incarnation of the Divine Spirit, which is an emanation of the Deity and is fairly equivalent to the Reason, Word, or Spirit of the Plotinian philosophy. In later times this doctrine 
has rather fallen into the background, perhaps as the result of western influences, but the earlier phase shows a repetition of the traditional Persian position. All these sects show common matter in the doctrines of incarnation, of transmigration, and of an esoteric teaching to be revealed only to the elect. Such were the extremer Shi'ite sects of mediaeval times, and such are their descendants of modern times. Even in Persia to-day, side by side with the more orthodox "Twelvers" of the state church and off-shoots such as the Babists, the latest of a long series of mystical developments from the Shi'ite stock, are the "Ali Allahis who believe in the deity of the Imam 'Ali, and combine with this belief many elements from the ancient Zoroastrian religion, a survival of the older mediaeval Shi'ism which caused so much trouble to the Khalifate of Baghdad.

In the teaching of most of the Shi'ites it is believed that some deceased Imam was an incarnation of deity, and it is he who, not really dead as men suppose, has passed into concealment, to return again in the fulness of time, when this evil age in which the true Khalifate no longer exists has passed away. Neanwhile there is no valid Khalif or Imam upon earth, but only some Shah or ling who acts as vicegerent of the hidden Imam until his return.

This digression serves to show us how strongly Persian thought always has inclined towards the idea of a divine incarnation in the honoured religious teacher, and towards that of transmigration of the soul from one such teacher to his successor. In the 3 rd century A.H. probably no sect which did not hold such theories could have obtained a favourable hearing amongst the Persians who found Islam of the Arab type unsatisfying, and every radical religious movement was necessarily compelled to assume at least the externals of Shi'ism.

The Shi'ite party organised by 'Abdullah is known by various names. It is called Isma'ilian as representing the party adhering to Isma'il, the son of Ja'far as-Sadiq, and his son Muhammad, as against those who continued the succession of the Imamate through Musa; but the name is not strictly accurate as it seems that there was an Isma'ilian sect proper existing before 
'Abdullah, and that his re-organisation was so drastic that we may regard the continuity as being severed; and it seems certain that some part of the earlier sect continued to exist independent of his reforms. It was, no doubt, its attachment to a deceased or " hidden", Imam which made it a more promising field for the advocates of a speculative philosophy than any sect whose Imam was living and might dissociate himself from the doctrines held. It was also called the Sab'iya or "Seveners" because it accepted seven Imams, and also because it attached a sacred significance to the numeral seven; there were seven prophets, seven Imams, seven Mahdis, seven grades of initiation (afterwards changed to nine), etc. In many respects $S a b^{6} i y a$ is the most accurate name, but it is open to the same objection as Isma'ilian. More commonly its members are called Fatimites as recognising Fatimid Imams who claimed descent from 'Ali and Fatima: but this, although convenient because of its frequent use amongst mediaeval Arabic writers, is peculiarly inaccurate. The Ithna 'ashariya or sect of "Twelvers" was equally Fatimite, and so were the Zaydites, indeed these last were the true Fatimites as holding that any person descended from 'Ali and Fatima might be a valid Imam: but common usage allows the use of "Fatimites" for the sect organised by "Abdullah. Another name is Batinites or advocates of an allegorical interpretation, but this also applies to other Shi'ite groups. Sometimes they are called Qarmatians, but this name is only applicable to one branch of the sect which originated in the district of Sawad between Basra and Kufa, and should be reserved for that branch which at a later period became alienated from the main Isma'ilian body.

The new sect carried out its propaganda by means of missionaries $\left(d a^{\prime} i\right)$ on the lines developed by the Hashimites. In this, as in most of its external features, it reproduces the characteristics usual amongst the mediaeval Shi'ites.

The organiser of the sect or masonic fraternity was 'Abdullah, who is stated to have been the son of one Maymun. Sometimes "Abdullah is surnamed alZaddah (" the oculist"), as is done by Abu l-Feda, but more often this surname is given to his father Maymun. Maqrizi, referring to the Fatimids, says, "this family" 
was traced to al-Husayn, the son of 'Ali ibn Abi Talib, but men are divided in the matter between two opinions: some treat it as true, but others deny that they are descendants of the Prophet and treat them as pretenders descended from Daysan the Dualist, who has given his name to the Dualists, and (say) that Daysan had a son whose name was Maymun al-Qaddah, and that he had a sect of extreme views. And Maymun had a son 'Abdullah, and 'Abdullah was learned in all the canon law and customs and sects " (Maqrizi, i. 348).

The reference to "Daysan the Dualist" is pure fable. This Daysan appears frequently in Arabic history as the legendary founder of the Zindiqs, a name given to the followers of the pre-Islamic cults of Mesopotamia and Persia, who found it convenient to make external profession of Islam. Thus Mas'udi (Murui adh-Dhahab, viii. 293) says that " many heresies arose after the publication of the books of Mani, Ibn Daysan, and Marcion, translated from Persian and Pahlawi by "Abdullah ibn al-Muqaffa' and others." Ibn alMuqaffa' was a converted Zoroastrian who took a leading part in translating Persian and Syrian works into Arabic under the first two 'Abbasids, and was generally regarded as privately adhering to his earlier religious views.

It will be noted that Zindiqism is mentioned as propagated by Ibn al-Muqaffa', and is traced to Ibn Daysan amongst others, and this is precisely the same as the one whom Maqrizi names as the reputed progenitor of Maymun. Evidently the charge which lay at the bottom of this latter statement originally meant that Maymun was a Zindiq, and so could be described as a follower of Ibn Daysan, not that he actually was Ibn Daysan's son, which would be an absurd anachronism. For the name Ibn Daysan refers to a perfectly genuine historical person: the Ibn Daysan of the Arabic writers was the Bar Daisan of Syriac literature, a convert from paganism to Christianity who died about A.D. 222, and whose followers formed an important sect at Edessa for several centuries, thought in Muslim times he appears as a semi-legendary character. IVe possess a work probably written by one of his pupils called "A treatise on Fate" in the Christian writers, from which two lengthy extracts appear in Eusebius: 
Praep. Evangel. vi. 9, one of which is cited also in Clementine Recognitions ix., but is headed "Book of the Laws of Countries" in the Syriac text discovered by Cureton, and published by him in 1855 . Various references are made to Bar Daisan in Euschius, Epiphanius, and other Church Fathers, as well as in the dialogues ascribed to Adamantius, but our best information as to his teaching is to be obtained from Moses bar Kepha (Patrol. Syr., I., ii. 513-5), whose summary is fully endorsed by the controversial essays of St. Ephriam, who settled at Edessa in 363 when the Bardaisanites were a real force there. Bar Daisan's doctrine, which is a kind of Christianized Zoroastrianism, is described by Prof. Burkitt in his introduction to Mitchell's edition of St. Ephraim's Prose Refutations.

Marcion represents an earlier and more definitely Christian system which at one time had a very wide extension, and probably was the medium through which Bar Daisan learned Christianity. It was a kind of dualistic system with two powers, the Good God and the Evil One. The Evil One was the creator whom the Jews worshipped as God, and the Good God sent his Son on earth to save men from this delusion: as in Zoroastrianism the two rival powers maintain an unceasing strife until the day of judgment when the good God will be finally victorious. From St. Ephraim we learn that the Marcionites long retained their hold in Northern Mesopotamia side by side with the Bardaisanites.

Mani shows very much these same views in a Zoroastrian setting, but with a strong element of Marcionite Christianity. Mani's work came some twenty years later than Bar Daisan, and he, in his early days, had been a disciple of the Mandeans, the Gnostic sect which Justin Martyr calls "the baptists",

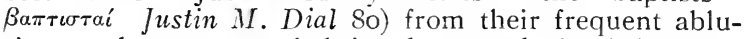
tions, who were settled in the marsh land between Basra and Wasit on the lower Euphrates. All three, Bar Daisan, Marcion, and Mani, draw largely from the same source the eclectic mixture of old Babylonian religion, of Zoroastrianism, Buddhism, and Christianity, which developed in the lower Euphrates valley, though Marcion claimed to be, and no doubt believed 
himself, an orthodox member of the Catholic Church. whilst. Mani was no less confident in regarding himself as a Zoroastrian. The whole of the different religious ideas of the Euphrates valley were welded together by an element of Greek philosophy of the neo-Pythagorean type, which seems to have filtered in through the Jews who were settled there in force, and had shared in the common life of the Hellenistic world at the time when the neo-Pythagorean school was taking form, and showing marked sympathy towards the various forms of Eastern religious speculation. All this kind of eclectic speculation, half religious and half philosophical, lived on, and was still alive in the third cent. of the Hijra; indeed, it had spread and formed a new centre at Harran, quite distinct in its character, but obviously drawing from the same sources, and, moreover, it quickened into new life when the speculations of the neo-Platonic school were introduced through a Syriac medium. Traditionally all this type of thought prevalent in Mesopotamia was connected with the names of Marcion, Mani, and Bar Daisan, though probably very few Muslims had any clear idea of the respective parts these three characters had played, but simply cited them as heresiarchs of exceptional notoriety.

But Maymun was without doubt a real character. Abu 1-Feda refers to him as a native of Qaraj or Ispahan, who professed to be a Shi'ite, but was really a Zindiq, i.e., a follower of the heresies of Marcion, Bar Daisan, and Mani, or else a materialist (Abu l-Feda, Annales Moslem., ii. 3II). Lsed in this sense "materialist" means an Aristotelian, i.e., one who believed in the eternity of matter and so did not accept the Qur'anic teaching of creation $e x$ nihilo. Ibn Khaldun states that Maymun migrated to Jerusalem with a number of his disciples and became well known as a magician, fortune teller, astrologist, and alchemist (cf. Quatremère: Journ. Asiatique, Iug., i 836). The Fatimid advocates, as represented by the Druze writers, fully admit the descent of the Fatimids from Maymun, but claim that he was of the family of "Ali (cf. De Sacy : Chrestom, ii., note 3 on page 95), which seems as though Maymun's position as an ancestor of Abdullah's family was beyond question.

In the passage already quoted Maqrizi describes 
'Abdullah as " learned in all the canon law and customs and sects," so that it seems that he, the fortune teller's son, was credited with being the original teacher and founder of the sect. Perhaps Maymun himself was the founder of a minor off-shoot of the Isma'ilian body,we hear of followers who went with him to Jerusalem,and 'Abdullah succeeded him as head of this group but, himself a student of philosophy like so many other Shi'ites, and participating in rationalistic opinions, used his position to form a kind of free-masonry, in which he developed more fully the principles already indicated by Ja'far as-Sadiq, and so made the Aristotelian and neo-Platonic teaching somewhat modified in a Persian guise, the " hidden meaning " of the Qur'an. Probably he too was responsible for the efficient organizing of the sect, although its missionary propaganda was, as has been noted, reproduced from that of the Hashimites. He is said to have been the author of a book called al-Mizan, "the balance" (Abulfeda : Ann. Mus., ii. 310). According to Nuwairi, who used the history of Abu l'Hasan b. 'Ali Akhu-Muhsin, himself a descendant of Isma'il b. Ja'far and a contemporary of the chief activity of the Isma'ilian sect, 'Abdullah assumed Shi'ite views, not because he wanted to get men to recognise the Imamate of Isma'il or his son Muhammad, but simply as a device to attract adherents : such was Akhu-Muhsin's view, no doubt a prejudiced one, but of some weight as undoubtedly the judgment of many contemporaries. It is, however, quite as probable that the "Alid theories were derived from the existing sect of which Maymun had been head, and were left unaltered by his son when he took it in hand.

In order to make proselytes, 'Abdullah's missionaries used to propose obscure questions about the Qur'an and the doctrines of traditional Islam, with the object of showing that as generally held these doctrines were contrary to reason, and so required an explanation. The revelation of Islam, they said, was difficult, and hence there was much diversity of opinion and many sects and schools of thought, all of which caused an infinite amount of disedification and much trouble. The reason of these diverse opinions is that each man follows his own private judgment and forms his own conjec- 
tures, with the result that many end in utter unbelief. But God would not give a revelation full of such obscurity and ambiguity as the only guidance for men. It must be that there is some available guidance, some authoritative teacher who can explain the doctrine so that it may be both clear and certain, and such an infallible teacher implies an Imam. The $d a^{\prime} i$ then gave illustrations of the obscurities and difficulties which men are not able to understand by the light of their own reason. The pilgrims at Mecca throw stones and run between the two hills, Safa and Merwa,- - what is the purpose and meaning of this? Why is it that a woman who has omitted a fast and prayer because prevented by reasons of personal impurity is required to fast afterwards to make up for her omission, but is not required to make up for the omitted prayer? Why did God take six days to create the world when he could quite well have created it in an hour? What does the Qur'an mean when he refers in a figurative manner to the "way" ? What is the meaning of the reference to the two angels who write and take note?-why cannot we see them? What really are the torments of hell? What mean the words " and over them on that day eight shall bear up the throne of thy Lord "? (Qur., 69, I7). What is Iblis?-Who are Yajuj and Majuj (Qur., i8, 93), and Harut and Marut (Qur., 2, 96)? Why have there been created seven heavens, and seven earths, and why are there seven verses in the Fatha? and many similar questions all designed to show that the Qur'an is full of references to things which are not explained and need explaining, but to which the orthodox teachers are unable to give an explanation. All these are the conventional arguments which are commonly employed to prove that revelation is incomplete without an authorised teacher.

They then continued to ask other questions which throw a curious light on the kind of problems which interested the Muslims of the day, or which could be thought as deserving of attention. Why have men ten fingers and ten toes?-why are four fingers on each hand divided into three phalanges, whilst the thumbs have only two each?-why has the face seven openings? -why are there twelve dorsal vertebrae and seven cervical vertebrae? etc., constantly suggesting some 
mystic meaning as lying under particular numbers. They cited " on earth are signs of men of firm belief, and also in your own selves; will ye not them consider them? (Qur., 5I, 20-2I): " God setteth forth these similitudes to men that haply they may reflect" (Qur., 14,30 ), and "we will shew them our signs in (different) countries and among themselves, until it become plain to them that it is the truth."

These suggestions produced doubt in the minds of many hearers, and gave the impression that the missionary had thought more deeply on the problems of religion than the ordinary teachers; and so the hearers were induced to ask the $d a^{6} i$ to instruct them and reveal the answers to some of the problems he proposed. Forthwith he would begin a discourse dealing with some of these questions, and then suddenly check himself : the religion of God is too precious to be disclosed to those who are not worthy and who may, perhaps, treat it with contempt: God has always required a pledge of those to whom he has disclosed his mysteries. Thus we read, "And remember that we have entered into covenant with the prophets and with thee, and with Noah, and Abraham, and Moses, and Jesus the son of Mary ; and we formed with them a strict covenant" (Qur., 33, 7), and again " some there were among the faithful who made good what they had promised to God" (id., 23),- "O believers, be faithful to your engagements "(Qur., 5, I),- " "be faithful in the covenant of God when ye have covenanted, and break not your oaths after ye have pledged them: for now ye have made God to stand surety for you "'(Qur., r6, 93), and many similar passages. "So now," the $d a^{6} i$ said, " pledge yourself, putting your right hand in mine, and promise me with the most inviolable oaths and assurances that you will not betray our secret, that you will assist no-one against us, that you are laying no snare for us, that you will use the truth only in speaking with us, and that you will not join any of our enemies against us." By this means they discovered how far the would-be proselyte was ready to be submissive and obedient, and accustomed him to act in absolute conformity with his superiors. If the proselyte readily took this pledge, the missionary next said, "Give us now an offering from your goods and first fruits which 
shall be a preliminary to the disclosure which we are about to make to you of our doctrine, and a pledge which you will give for it." By this they tested how far the proselyte was prepared to make sacrifices to join the sect, and how far he could be trusted to be a loyal and devoted member. Thus the proselyte was admitted to the First Grade which consisted of those who accepted the principle that the Qur'an has both an external literal sense and an inner esoteric meaning which needs the help of an interpreter. The inner meaning was termed batin, or iman, " faith," as distinguished from the external islam, and this distinction was justified by the words of Qur. 40, 14. "The Arabs of the desert say, 'we believe.' Say : 'Ye believe not, but rather say, "we profess Islam'; for the faith has not yet found its way into your hearts."

The Second Grade. When the disciple had fully adopted the ideas taught in the first grade, and was convinced that men have fallen into error by accepting the traditional teachings of Islam, the $d a^{i} i$ used the ordinary arguments to persuade them that there was need of an authoritative teacher, and without such a teacher men are unable to please God or obey $\mathrm{His}$ laws. Great stress was laid upon the unreliability of private judgment and the need of guidance and authoritative teaching.

Third Grade. The da' $i$ next proceeds to point who can be accepted as the desired teacher and infallible guide, the Imam of Islam. There have been seven such Imams, as worthy of reverence by their religious characters as by their number, for the most important things in the universe, such as the planets, the heavens (Qur. 2, 29; 67, 3), the earths (id. 65, 12, of Bukhari Sahih 59, 2) are invariably in sevens. He then enumerates the seven Imams, the first six being "Ali to Ja'far as-Sadiq, the seventh al-Ka'im, " the chief," whom some understand to be Ja'far's son Isma'il, others his grandson Muhammad, whilst others again regard these two as but one. He next endeavoured to show that the other Shi'ites, who regard Musa as the seventh Imam, cannot be correct as they do not limit the Imams to the sacred number seven, but continue until twelve are reckoned in all. He then was accustomed to speak against the character of Musa, the son 
of Ja'far, asserting that Isma'il had deep knowledge of secret things, whilst Musa possessed no such supernatural enlightenment : he told anecdotes which placed Musa in an unfavourable light, and even attributed to him grave sins, so that it was impossible to regard him as the true Imam. Moreover it was agreed that, since Husayn, the Imamate can only be passed by direct succession, so it is not possible that it could be taken from one and given to his brother. The Isma'ilians alone have inherited the accurate knowledge of secret mysteries bequeathed by Ja'far as-Sadiq to his son Isma'il.

Fourth Grade. In this grade instruction was given in the history of God's revelation. The age of the world is divided into seven stages, each under the guidance of a prophet whose teaching surpassed that of his predecessors and abrogated it. Between each pair there were but "silent" guides who did not add to nor alter the revelation of the prophet who inaugurated that age. Each of these seven prophets had a coajutor who was his authorised exponent to mankind at large. These seven prophets and coadjutors were-

(i.) Adam, with coadjutor Seth.

(ii.) Noah, with coadjutor Shem.

(iii.) Abraham, with coadjutor Isma'il.

(iv.) Moses, with coadjutor, at first Aaron, then Joshua.

(v.) Jesus, with coadjutor Simon Sifa (Cephas).

(vi.) Muhammad, with coadjutor 'Ali.

(vii.) al-Ka'im, with coadjutor 'Abdullah.

Thus the seventh prophet al-Ka'im, i.e., Isma'il or his son Muhammad, has abrogated the teaching of the Prophet Muhammad, and has given a new revelation. At this point, therefore, the convert was entirely separated from orthodox Islam which accepts Muhammad as the "seal of the prophets," that is to say, the final completer of revelation, and was taught to regard his religion as obsolete.

Fifth Grade. In this grade it was taught that the traditional practices of the religion of Islam were merely temporary, a concession to the uninstructed multitude who could not yet understand the spiritual principles of iman: they were useful as an educative 
influence with the ignorant, but the Qur'anic precepts on which some of them were based had an esoteric meaning quite other than their literal form, whilst the traditional rules which had added so much detail to the laws of the Qur'an were baseless and negligible. The disciple was taught to replace the external precepts of Islam by inner convictions. If he was a Persian he was reproached with the servile submission which the Persians had rendered to an Arab Khalif : if he were an Arab he was instructed that the privileges of the Arabs have now been transferred to the Persians. In addition to this he was taught certain principles of geometry and the properties of numbers, all applied in a mystical manner to the claims of the Imamate. He was further informed that each prophet had twelve hujjaj corresponding to the twelve signs of the zodiac, to the twelve months of the year, to the twelve tribes of Israel, and to the twelve nugaba' whom Muhammad chose from the ansar or " helpers" at Madina. These numerals "seven" and "twelve", which have been shown to possess sacred meanings, were now cited to explain why men have twelve dorsal vertebrae, seven cervical vertebrae, etc. It is as well to note that when these teachings were first put forth the other Shi'ies who followed Musa and his successors had not yet made up the number of twelve Imams.

Sixth Grade. The missionary did not admit the postulant to this grade until he was perfectly assured as to his discretion and secrecy. In it the teaching that the ritual precepts of Islam as generally understood, were abrogated, was carried to its logical conclusion, and the convert was instructed to abandon the observance of prayer, fasting, pilgrimage, and all the other external practices of religion; or at least to observe them only in so far as they served as a bond of social usage or as expedient as a concession to their uninstructed companions. At the same time the teacher professed the utmost veneration for the men who had established these practices, and for the wisdom which had led them to do so. The $d a^{6} i$ then described to his pupil the doctrines of Plato, Aristotle, Pythagoras, and other philosophers, and exhorted them not to follow the traditions of religion which have been passed down as mere hear-say, but to test them by the 
methods of philosophy and to accept only those things which are endorsed by reason. Changing his former attitude, he then began to criticize the Imams unfavourably, and to contrast them with the philosophers to their disadvantage.

Seventh Grade. Some of the missionaries were not themselves instructed in the doctrines of the highest grades, and only a select number were able to initiate converts into this seventh stage. This serves as the probable explanation of some events in the history of the sect which appear strange at first sight such, for example, as the estrangement of the most faithful and successful missionary Abu 'Abdullah who, no doubt, revolted when he found the difference between the actual beliefs of the Mahdi 'Ubayd allah, and the doctrine which he himself had learned and taught. In initiating a disciple into this highest grade the $d a^{6} i$ first pointed out that there are in this world always correlatives, of which one is the cause, the other the result, as giver and recipient, teacher and taught, etc. Thus the Qur'an tells us of God that "when he decreeth a thing he only saith "be" and it "is" (Qur., 3, 42), in which God, the First Cause, is the greater, the thing created only derives its being from him : and again, "all things have we created after a fixed decree" (Qur., 54, 49), and again, " he who is God in the heavens is God in earth also " (Qur., 43, 84). Hence, following a teaching of the philosophers, it is clear that from a Being who is only One, only one thing can proceed: but the world contains many things, so it cannot be the work of the One, but needs at least two Beings. Moreover, creation is not the bringing into being that which did not previously exist, but only the arrangement and disposing of things. At bottom this was intended to be a statement of the Aristotelian doctrine of the eternity of matter, and shows striking resemblances with the speculations of the Mu'tazilites. Thus Abu Hudhayl (d. circ. 226) held that before the creation of the world existed, but in a state of perfect quiescence; creation was the introduction of change and movement, and this theory, in one modification or another, recurs in all the speculations of the later Mu'tazilites. Very similar is the teaching of al-Farabi (d. 339), who was himself a 
member of the Isma'ilian sect, and held that the world proceeded from God in an instant of the immeasurable eternity which preceded time, but remained at rest until at creation God introduced movement and so produced time and change.

Such was the teaching of the seven grades which formed the original constitution of the sect. Later on two higher grades were added which, for the sake of completeness, we may consider here although they were no part of the original scheme.

Eighth Grade. In this the disciple learned that there are two Principles, the original and primary Cause, without name or attribute, the pre-existent (as sabiq) who seems to be very much the same as "the first God " of Plotinus, and a Second proceeding from this First Cause, due to a thought in the pre-existent, i.e., as an emanation, just as the spoken word proceeds from the thought in the mind of the speaker. Of the pre-existent nothing can be stated but what is negative. The " Second " seems to be very similar to the Reason or Active Intelligence as defined by the philosophers on the basis of Alexander of Aphrodisias' explanation of the teaching in Aristotle de Anima; not, as in the Zoroastrian system, a rival power, but an emanation which is an intermediary between the unknowable God and man. The true prophet, the $d a^{\prime} i$ declared, is shown, not by working miracles which impress the vulgar, but by the establishment of political institutions which equip a stable and well disposed government, and bv the teaching of spiritual doctrines which give an explanation of the phenomena of nature. Then, as Nuwairi and Maqrizi state, the Qur'an, the resurrection, the end of the world, the last judgment, and such like doctrines of Islam are explained away as having allegorical meanings: according to the batinite doctrine, all these things signify only the revolutions of the planets and of the universe in regular rotation, or the production and destruction of things according to the arrangement and combination of elements, as explained in the teachings of the philosophers.

Ninth Grade. In this grade the disciple was taught the doctrines of the philosophers and what they have stated about the heavens, the stars, the soul, the intelligence, and other like things: in all he was made 
grades which were a later addition were more definitely based on the teachings of the Greek philosophers which had been popularised in the Muslim world. At the same time the disciple learned that Abraham, Moses, and the other prophets were only founders of lecal and social systems; they had received their learning from Plato, and the other philosophers who consequently are more important than the prophets commonly revered. He was especially taught to abhor the Arabs because they had been responsible for slaying Husayn, for which crime they were deprived of all rights to the Khalifate and Imamate, which were transferred to the Persians.

Maqrizi says that the members of 'Abdullah sect who attained to the highest grade became mu'attil and ibahi (Maq. i. 348). Strictly speaking the former term denotes one who denies that the universe has a creator, and therefore implies that the initiated held the doctrine common to most of the Arabic " philosophers " of the eternity of matter. This teaching was one of the leading charges brought by the orthodox Muslims against Aristotle. The second term seems to mean "one who admits as (or makes) allowable," and implies what would be described as antinomianism. Maqrizi continues that the initiated " did not any longer recognize any moral law, nor expect either punishment or future reward" (id.). The historian Nuwayri gives the same account of the Qarmatian branch of the Isma'ilian sect. Such antinomianism is not at all unknown amongst Muslim devotees: thus Maqrizi (ii. 432) in another passage refers to the Qalandariya darwishes as a type of Sufis who disregard fasting and prayer, and have no reluctance to use any form of self-indulgence, saying that it is sufficient that their hearts are at peace with God. These darwishes were of Persian origin and appeared in Syria in the 7th cent. A.H., but their order had its beginning in the 5 th cent. Antinomian ideas appear with the later Murji'ites of the 2 nd cent., and are represented in the doctrines of Jahm b. Safwan, who was put to death about I3I, and was, characteristically enough, a Persian convert in rebellion against the Arab Khalif. Amongst these Murjicites we find the doctrine of to assume the system of those who believed in the 
eternity of matter. Thus it will be seen the two highest taqiya or " concealment," which afterwards became common amongst the Shi'ites, the doctrine, namely, that profession of faith means only the confession of the soul to God, it being allowable that the true believer outwardly conforms to any religion.

Nuwayri also gives the form of contract proposed to a convert at the time of his initiation. This appears in two parts, to each of which the convert gives assent. They may be summarised thus :

(I) A promise before God, and before his Apostle, his prophets, angels, and envoys, to inviolable secrecy as to all the convert knows about the missionary, about the representative of the Imam in the district where he lives, as well as regarding all other members of the sect. A pledge to accept all the orthodox teachings of Islam, and to observe all its rites, both matters which, as we have seen, were required of the lower grades and disregarded by the higher ones.

(2) A pledge to loyalty towards the missionaries and the Imam, and the invocation of the curse of Iblis if this pledge is broken. "If you have any reservation, in will or thought, this oath nevertheless has full binding force upon you, and God will take no satisfaction other than the complete fulfilment of all it contains and of the agreements made between you and me."

This oath, it will be observed, is intended for those initiated into the first grade, and so conforms to the idea of orthodox Islam, though including the Shi'ite doctrine of an Imam, but covers all that is to be taught later with a veil of secrecy. The plan was to adapt the earlier teaching to the beliefs and capacity of the proselytes, and this method is further illustrated by the kitab as-siyasa or " book of policy," a manual for the guidance of the $d u^{\prime}$ at, which Nuwayri describes on the authority of Abu 1-Hasan.

According to this the teacher is told to emphasize his zeal for Shi'ite theories if he has to deal with a Shi'ite, to express sympathy with ' $\mathrm{Ali}$ and his two sons, and repugnance towards the Arabs who put them to death. If he has to deal with a Sabian, emphasis was laid on the reverence paid to the numeral seven. If his conversation was with a Zoroastrian, his principles are at 
the basis very similar to those of the Isma'ilians, and with him the $d a^{6} i$ may commence at the fourth grade. If his business is with a Jew, he should explain that the Mahdi Muhammad b. Isma'il is the Messiah expected by the Jews and speak much against the Muslims and Christians, especially about their erroneous beliefs as to the unique birth of Christ, making it plain that Joseph the carpenter was undoubtedly his father. With Christians, on the contrary, it is advised to speak ill of the Muslims and Jews, explaining that the Isma'ilians recognise the Christian creed, but giving it an allegorical interpretation, and showing that the Paraclete is yet to come, and is the true Imam to whom they are invited to come. In dealing with dualists or Manichaeans the $d a^{\prime} i$ may begin at the sixth grade of initiation, or if the convert seems worthy of confidence, the whole doctrine may be revealed at once. With one of the "philosophers" who, in true Muslim fashion, are treated as a distinct sect, emphasis is to be laid on the fact that the essential points of the Isma'ilian faith are based on the teachings of philosophy, and the sect agrees with them in everything concerning the prophets and the eternity of the world; but some of the philosophers differ from the Isma'ilians in admitting a Being who rules the world, though confessing that he is unknown. With "dualists," i.e., Muslims of the sect so called (cf. De Sacy: Druses, p. 1xviii., note 3 ), victory is sure; it is only necessary to dwell on the doctrine of the pre-existing and the second. With orthodox Sunnis the missionary is to speak with respect of the early Khalifs, avoid eulogies upon 'Ali and his sons, even mentioning some things about them which call for disapproval: great pains should be taken to secure Sunni adherents as they form most useful defenders. When dealing with a Shi'ite who accepts Musa, the son of Ja'far, and his descendants, great care is necessary : the $d a^{6} i$ should dwell on the moral laws of Islam, but explain the sacred associations of the number seven. With some it is impossible to venture further and show that the religion of Muhammad is now abrogated, with others it is possible even to show that the ritual laws of the Qur'an are obsolete, with a few he may proceed to admit that the Ka'im is really dead, that he comes 
back to the world only in a spiritual manner, and explain allegorically the doctrine of the resurrection of the dead. Each is to be dealt with according to his beliefs, and care must be taken not to offend his religious prejudices. The $d a^{\prime} i$ is advised to study the history of ancient legislators, their adventures, systems and sects, so as to have a fund of illustration which will arrest the attention of their pupils.

Such was the system formed by 'Abdullah, probably somewhere before A.H. 250, and by him grafted on the already existing sect of Shi'ites, which upheld the claims of Isma'il, the son of Ja'far. In the reign of Ma'mun (A.H. I98-2I8) 'Abdullah had joined the revolt of Ishaq b. Ibrahim at Karkh and Ispahan, and formed a close friendship with the weaithy Muhammad b. Husayn b. Jihan-Bakhtar ad-Didan, a Persian prominent for his intense hatred of the Arabs, and it was he who first supplied 'Abdullah with funds to begin his propaganda (cf. Quatremère in Journ. Asiat., Aug., I836). It is not easy to form any clear scheme of the chronology of the sect in its early days, nor to follow the details of its history: conspiracies and secret societies do not leave much in the way of documentary evidence of their first formation. That 'Abdullah was associated with a rebellion in the reign of Ma'mun is hardly likely; it seems rather that Muhammad b. Husayn ad-Didan (Dandan, or Zaydan) was so associated, and he afterwards befriended 'Abdullah. This Muhammad was secretary to Ahmad ibn 'Abdu 1-'Aziz ibn Abi Dolaf, who became prince of Karaj in A.H. 265. No doubt 'Abdullah was a younger contemporary, assisted by the old anti-Arab agitator. Certainly 'Abdullah was established at Basra, whither he had removed from Persia, before $26 \mathrm{I}$ (Fihrist, I 87 ), lodging there with the family of 'Agil ibn Abi Talib. Thence he went to Syria, presumably finding suspicion aroused at Basra, and made his headquarters at Salamiva in the territory of Emessa (Maq. i., 348-9: ii., II), and from there sent out missionaries who preached the claims of Muhammad $b$. Isma'il $b$. Ja"far as the "concealed" Imam, and of "Abdullah himself as the Mahdi or " guide," who was to prepare men for the Imam's return to earth (Maq. i., 348). At Salamiya he had a son named Ahmad, and when he died Ahmad succeeded him as head of the sect. 
Ahmad, like his father, sent out missionaries, and one of these was instrumental in founding the important brach known as the Qarmatians, a branch so important and prominent that some, e.g., Jamal ad-Din, have regarded the Isma'ilians as their offshoot. The fact seems to be that there were at first members of one body, then circumstances gave the Qarmatians a political opening in Syria and 'Iraq, and, in a position of independence, they developed their doctrines more openly than the rest of the sect and, being drawn from the peasant class, these assumed a grosser form : whilst the other or parent community found a career in Africa but, as they became there a ruling minority with a subject majority of orthodox type, they were induced to observe some semblance of orthodoxy.

'Abdullah was succeeded as head of the Isma'ilian sect by his son Ahmad. According to the Fihrist he was succeeded first by his son Muhammad, then by a second son Ahmad, the latter being also described as the son of Muhammad, and so grandson of 'Abdullah (Fihrist, p. 137). This Ahmad may be the one who was at Basra for some time, then at Kufa, whence in 266 or thereabouts he sent missionaries to Yemen; possibly he was the Ahmad al-Qaiyal who wrote a book on the Imamate, which was refuted by Razi (d. 320).

After Ahmad came his son Husayn, who died not long afterwards, leaving a son named Sa'id, who subsequently took the name of 'Ubayd Allah, and was the Mahdi who established the Fatimid State in North Africa, dying in A.H. 323 (=A.D. 934). That he was originally called Sa'id is generally admitted, but he appears variously as Sa'id son of Husayn son of Almad, and Sa'id son of Ahmad, and Sa'id son of Abu Shalaghlagh. The explanation given for these different names is that Ahmad had two sons, of whom the elder, Husayn, died whilst Sa'id was still young, and the son was adopted by his uncle Muhammad, the second son of Ahmad, who was also known as Abu Shalaghlagh.

There is a story that Sa'id or "Ubayd Allah was the son of an obscure Jewish smith, whose widow was married to Husayn, son of Ahmad, and that he was adopted by his step-father. This is one of the three forms of what we may call the " Jewish legend," the 
attempt to trace the Fatimid dynasty to a Jewish source. These three attempts are: (i.) that Maymun b. Daysan the oculist was a Jew; (ii.) that 'Ubayd Allah was really the son of a Jewish smith; and (iii.) that he was killed in prison at Sijilmassa, and afterwards personated by a Jewish slave. Probably the "Jewish legend " was associated with the fact that the renegade Jew, Ibn Killis, was the one who encouraged the Fatimids to invade Egypt and did most to organise their government there, and with the undoubted favouritism which the early Fatimids showed the Jews.

A new development in the teaching of the sect took place under Husayn, or possibly commenced under his father Ahmad. "Abdullah had been content to describe himself as the "Mahdi" or guide, who was to lead men to the Imam, who was Isma'il, or his son Nuhammad; he made no claim to be himself a descendant of the Imam. Probably it was a later theory that the Imam was "concealed" only in the sense that he had to hide himself from the "Abbasid Khalif. Later still, when a Fatimid Khalif was actually ruling in Cairo, the claim to descent from 'Ali through 'Abdullah and his family became a matter of heated controversy.

Historians differ very much as to how far the Fatimids succeeded in proving their 'Alid descent, and contemporary opinion was quite as varied. Abu 1-Hasan Muhammad Masawi, commonly known as Radi, born at Baghdad in 359 and dying in 406, was himself an undoubted descendant of Husayn the son of 'Ali, and was official keeper of the records of 'Alid genealogy. As Abu 1-Feda notes (Ann. Mosl., ii. 309) he, in one of his poems, fully admits the legitimate descent of the Fatimids of Egypt from 'Ali, and the actual passage is extant (cf. Diwan of Radi, Beirût, p. 972): but in 402 this same Radi joined with other 'Alids and certain canonists in a proclamation denouncing the Fatimids and declaring their claimed genealogy as baseless. It is natural to suppose that in this he was actuated by fear or complaisance, and this difficulty meets us throughout; the whole question was so much a matter of current political controversy that it was practically impossible to get anything like an unbiassed opinion. Maqrizi, the leading Egyptian 
authority of a later age, was strongly pro-Fatimid, but he claims the noble rank of sayyid on the ground of descent from 'Ali through the Fatimids, and so is prejudiced in their favour. $\mathrm{He}$ argues that the "Alid descent of the Fatimids was never attacked by the acknowledged 'Alids who then existed in considerable numbers (Maq. i., 349), an argument which is far from being true.

Elsewhere Maqrizi defends the Fatimid claims by saying that the "Alids were always suspected by the "Abbasid Khalifs, and so "they had no resort but to conceal themselves and were scarcely known, so that Muhammad b. Isma'il, the Imam ancestor of 'Ubayd Allah, was called the "concealed'" (Maq. i., 349). But this tells the other way: it admits that the 'Alid genealogy was not well known : and the mere fact that 'Abdullah was sought for by the Khalif simply shows that his pretensions were known to be dangerous, as a Mahdi with a body of followers would necessarily be, and is no proof of the validity of the descent afterwards claimed by 'Abdullah's descendants. The obscurity of the 'Alid genealogy afterwards favoured the Fatimid claims, but it does not seem that that claim was part of their original programme. The first idea was to support the claims of the vanished Imam, claims selected in all probability because of the convenient fact that he had vanished, and to represent 'Abdullah and his descendants simply as Mahdis, viceroys to guide and direct the people of Islam until the day came for the concealed Imam to be revealed again.

After the Fatimid claims had been laid before the world the 'Abbasids brought forward many calumnies (Maq. i., 349). The strongly anti-Fatimid Ibn Khallikan relates a story that when the first Fatimid Khalif to enter Egypt, al-Mo'izz, came to Cairo, the jurist, Abu Muhammad ibn Tabataba, came to meet him', supported by a number of undoubted members of 'Ali's family, and asked to see his credentials. Al-Mo'izz then drew his sword and cried, "Here is my pedigree": and scattering gold amongst the bystanders added, "And this is my proof." The story is an improbable legend, and even Ibn Khallikan rejects it on the ground that when al-Mo'izz entered 
Cairo, Abu Muhammad the jurist (d. 348) had been many years in his grave (Ibn Khall. iii., 366).

The weakest part of the Fatimid claim, as we have remarked, lies in the great diversity of forms the claim takes in different writers. When 'Ubayd Allah or Sa'id, 'Abdullah's great-grandson, established himself in Africa, the genealogy began to call for serious attention, and came to be examined, not by uncritical members of the sect, but by all the historians and genealogists of the Muslim world. It then appeared in no less than nine divergent forms.

(I) Traced through Ja'far as-Sadiq the sixth Imam, then through his son Isma'il, his son Muhammad "the concealed," then Ja'far al-Musaddiq-Muhammad alHabib-and then Ubayd Allah. Thus Maqrizi and Ibn Khaldun. According to this Abdullah and Ahmad do not appear in the descent at all.

(2) Traced through Ja'far to Muhammad " the concealed " as in the preceding, then "Abdullah ar-Rida (the accepted of God), - Ahmad al- Wafi (the perfect,al-Husayn at-Taki (the pious, - and Ubayd Allah the Mahdi. This appears in Ibn Khallikan and Ibn Khaldun, and seems to have been more or less the official version. According to this "Abdullah, the father of Ahmad, was the son of Mohammad "the concealed," not of Maymun. Similarly the proFatimid author of the Dastur al-Munajiimin (MSS. of M. Schefer, cited by de Goeje Qarmates, pp. 8-9), who says that Muhammad b. Isma'il took refuge in India; he had six sons, Ja'far, Isma'il, Ahmad, Husayn, 'Ali, and 'Abdu r-Rahman, but does not mention "Abdullah nor say which of these sons was the Imam: he then refers to the three "mysterious ones" as succeeding" Muhammad. Tabari (iii., 2218, 12) says that Muhammad b. Isma'il had no son nanied "Ibdullah.

(3) Is before, but Maymun as son of Nuhammad "the concealed," then "Abdullah-MuhammadUbayd Allah; thus in Abu 1-Feda. Maymun is made the son of the seventh Imam (which is impossible), and the Mahdi is represented as 'Abdullah's grandson (see below).

(4) Isma'il, son of Ja'far,-Muhammad " the concealed," - Isma'il, - Ahmad, - Lbayd Allah. This also occurs in Abu 1-Feda, and in Ubayd Allah's 
"Genealogy of the "Alids" (MS. Leiden, 686-cited by de Goeje, Qarmates, p. 9) Muhammad had three sons, Isma'il II, Ja'far, and Yahya; Isma'il had a son named 'Ahmad, who dwelt in the Maghrab.

(5) Isma'il-Muhammad " the concealed,"'-Isma'il II, - Muhammad, - Ahmad, - Abdullah, - Muhammad,-Husayn,-Ahmad or 'Abdullah,-Ubayd Allah the Mahdi. This is the genealogy given in the sacred books of the Druses, and rests on the theory, that there must have been seven "concealed Imams" intervening between Ja'far as-Sadiq and the Mahdi. It is merely an instance of the mystic value attached to the sacred numeral. Like (3) it gives Muhammad for Ahmad which is a permissible variant.

(6) The five preceding genealogies are distinctively Isma'ilian in character, but there are others which show adaptations of the "Twelvers" accounts, and these cannot be much more than later attempts to connect the Fatimid line with that recognised by the other Shi'ites. First we have the idea that the descent from Ja'far as-Sadiq was through Musa, not Isma'il, then following the next three Imams 'Ali ar-RidaMuhammad al-Jawad-'Ali al-Hadi (see above)-a'Hasan al-Askari-Ubayd Allah the Mahdi. According to this the Fatimite Mahdi in Africa was the son of the eleventh Imam of the "Twelvers," and thus replaced Muhammad al-Muntazar.

(7) The same line as the preceding, but admitting Muhammad al-Muntazar as twelfth Imam who "disappeared" in 260 , and asserting that "Ubayd Allah who appeared in North Africa was this same Muhammad emerging from concealment, after an interval of 29 vears.

(8) The same line as far as 'Ali al-Hadi, then Husayn, presumably a brother of Hasan al-Askari, and Ubayd Allah as son of this Husayn. This is given by Ibn Khallikan on the authority of a reference in Ibn al-Athir. All these three last genealogies must be dismissed as later suggestions since it is clear that the Isma'ilian sect rejected the Imams of the "Twelvers" after Ja'far as-Sadiq : but it may be that Ahmad's first claim was simply to be an 'Alid, and not necessarily the son of the house of Isma'il. 
(9) Finally we have another theory, mentioned by Ibn Khallikan, that the Mahdi was descended from Hasan, a brother of Ja'far as-Sadiq, and so an Alid but not an Imam, and from this Hasan came 'Abdullah, 'Ahmad, Hasan, and then 'Ali or Ubayd Allah the Mahdi. Back to 'Abdullah this was the generally asserted genealogy of the Mahdi's family, but Hasan, the brother of Ja'far, replaces Maymun.

The chief point is that there were so many alternative forms of the genealogy, and close scrutiny shows very weak points in every one of them. To the fully initiated this was a very small matter, as no importance was attached to the claim to the Imamate or to the descent from 'Ali at all. No doubt all these pedigrees served their purpose in dealing with the different types of proselytes, and their very diversity tends to prove that they were actually accepted and circulated in a sect which adapted its teachings to suit the opinions of the different classes with which it came into contact. It was not until the Fatimids became a political power that any need was felt to bring these various genealogies into any kind of agreement, and then, no doubt, the variant forms circulated by the different missionaries were a source of embarrassment. 


\section{III}

\section{THE QARMATIANS}

IVE turn now to the formation of the important branch of the Isma'ilian sect known as the Qarmatians, which is particularly interesting as we have detailed accounts of its formation which show how the propaganda worked, and illustrate the ease with which an armed group could set up an independent robber state in this period of the decay of the Khalifate. Of the history of their founding there are two leading narratives slightly divergent in details, - which De Goeje (pp. I3I7) calls A. and B. A. given by De Sacy (Druses. pp. clxvi., etc.) is that of Nuwayri, who drew his information from Akhu Muhsin, who obtained it from Ibn Razzam, and the substance, drawn from the same sources, appears in the Fihrist. B. (in De Sacy clxxi., etc.) is really the account given by Tabari, and is based on the description given by a person who had been present at the examination of Zaqruyah the Qarmatian by Muhammad b. Dawud b. al-Jarrah. The A. account is as follows.

One of Ahmad's missionaries named Husayn Ahwazi was sent to labour in the district of Kufa known as the Sawad. As he was travelling he met a man named Hamdan b. Ashhath al-Qarmati, who was leading an ox with forage on its back. Husayn asked him the way to a place named Kass-Nahram, and Hamdan replied that he was going there himself. Then Husayn asked him where was a place named Dawr, and Hamdan told him that was his home. So they went on together. Then Hamdan says: "You seem to have come a long way and to be very tired : get on this ox of mine." But Husayn declined, saying that he had not been told to do so. Hamdan remarked: "You speak as though you acted according to the 
orders which some one had given you." Husayn admitted that this was so. "And who," Hamdan asked, "it is then from whom you receive these orders and prohibitions?" IHusayn replied: "It is my master and yours, the master of this world and of the world to come.", After some reflection Hamdan said: " There is only God most High who is master of all things." “'True," replied Husayn, “'but God entrusts control to whom he pleases." Hamdan then asked, " Ithat do you intend to do in the village to which you have asked to be directed?" " I am going," said Husayn, "to bring to many people who dwell there a knowledge of the secrets of God. I have received orders to water the village, to enrich the inhabitants, to deliver them, and to put them in possession of their masters' goods."' Then he began to persuade Hamdan to embrace his teaching. Hamdan said: "I beseech you in the name of God to reveal to me what you possess of this wisdom : deliver it to me, and God will deliver you." " That," said Husayn, " is a thing I cannot do, unless I previously get from you an undertaking and bind you in the name of God by a promise as an oath like that which God has always exacted from his prophets and apostles. After that I shall be able to tell you things which will be useful to you." Hamdan continued to urge, and at last Husayn gave way, and as they sat by the roadside Husayn administered the oath to him and asked his name. Hamdan replied that he was commonly known as the Qamat, and invited Husayn to take up his abode with him. So Husayn went to his house and gained many converts from Hamdan's kinsmen and neighbours. There he stayed for some time, arousing in his host and others the strongest admiration of the ascetic and pious life he led, fasting by day, and watching by night. He worked as a tailor, and it was generally felt that the garments which had passed through his hands were consecrated. When the date harvest came a learned and wealthy citizen of Kufa named Abu 'Abdullah Muhammad b. 'Umar b. Shabab Adawi, hearing good reports of him, made him guardian of his date garden, and found him scrupulous in his attention and honesty. Husayn revealed his doctrines to this employer, but he saw through the piety which had 
impressed the villagers and understood that he was a conspirator. Before his death Husayn appointed Hamdan as $d a^{\prime} i$ in his place. This is an outline of the narrative of the origin of the Qarmatians, so called as the followers of Hamdan the Qarmat, according to the Sherif Abu 1-Hasan as reported in the history of Nuwayri.

Gregory Bar Hebraeus gives a different account which appears also in Bibars Mansuri and in another part of Nuwayri who cites the authority of Ibn Athir, and this is the second account which de Goeje calls B. According to it a Persian of Khuzistan established himself in the Nahrayn or district between the rivers, near Hufa, and soon drew attention by the asceticism and piety of his life. When anyone went and sat by him he used to discourse about religion and try to induce his hearers to renounce the world; he taught that it was a matter of obligation to pray fifty times a day, and that it was his office to guide men to the true Imam whose abode he knew. Some merchants purchased the produce of the garden in which this recluse had taken up his abode, and enquired for a trustworthy watchman to look after their property. The gardener introduced the recluse to them, and they gave him charge of the produce. When they came to take away their dates they paid the watchman, and he, on his part, paid the gardener for the dates supplied to him, deducting a rebate for the stones. The merchants saw this reckoning going on, and supposed that he had been selling some of their dates, so they struck him, saying, "Is it not enough that you have eaten our dates?-is it for you also to sell the stones?" The gardener then spoke up and told them the facts, and when they perceived their error they made their apologies and conceived a very high opinion of his rectitude and probity. Some time later he fell ill, and the gardener sent for a certain villager commonly known as Qaramita, a word which in the Nabataean language means a man with red eyes. This villager's real name is not given, but Tabari adds that Muhammad b. Dawud b. al-Jarrah said to someone that he was called Hamdan. He was an owner of oxen which were used to carry the produce of Sawad to the city of Kufa. He took the sick man to his house and there the devotee 
stayed until he was quite well, and whilst there taught the Qaramita the doctrines of the sect to which he belonged, and also instructed the villagers. From amongst his converts he chose twelve nakibs, in imitation of Moses and Jesus, and sent them out as missionaries. He required his followers to pray fifty times a day, and as a result the work of the villagers fell into arrears. A certain Haysam who possessed property in the village perceived this and made enquiry as to the reason; this led him into contact with the devotee who was induced to reveal to him his peculiar doctrines. Haysam perceived their subversive character and took him to Kufa where he locked him up in his house, but a female servant who was moved by the captive's apparent piety stole the key and set him free. In the morning the room was found empty, and this was reported as a miracle. Soon afterwards the devotee re-appeared to the villagers and told them that he had been set free by angels, and then he escaped to Syria. After his departure the Qaramata continued to preach and expand the doctrines which he had learned, and in this was assisted by the other nakibs. According to Ibn Athir, cited by Nuwayri, this Qaramat or Hamdan was a man who "affected a religious life, detached from the world and mortified," and "when anyone joined his sect Hamdan took a piece of gold from him, saying that it was for the Imam. From them (i.e., his followers) he chose twelve nakibs whom he charged to call men to his religion, saying that they were the apostles of Isa b. Maryam.'

The A. text refers to Husayn's death, the B. text says that he went to Syria. Tabari speaks of the devotee as coming from Khuzistan, but Akhu Muhsin says that he was sent by Ahmad from Salamiya. De Goeje (p. I8) suggests that he may have been Ahmad's son Husayn. According to the Kitab al-Oyun (MS. Berlin, 69-cited by de Goeje) Sa'id, the son of Husayn, the son of Ahmad, the son of Abdullah, was born at Salamiya in 259 or 260 . But evidently there is some error here. Husayn was the grandson, not the son, of Abdullah, and the head of the sect did not leave Askar Mokram before 266: probably not until after 
the repression of the slave rebellion in 270 . No open revolt of the Qarmatians took place until 286.

In his Chronicle Bar Hebraeus applies to the sect of the Nusayri all that he says about the Qarmatians, and so the books of the Druses in their references to the Nusayri prove that they hold very much the same doctrines as the Isma'ilians. It is supposed that the Nusayri sect is a survival of an ancient pagan conlmunity (cf. René Dussand: Hist. et religion des Nosairis, Paris, 190o). This fits in with the advice given to the missionaries that Manichaean converts may be admitted to a higher grade without hesitation.

After this rather confused account of the foundation of the sect of Qarmatians we find ourselves on surer ground. It is clear that Hamdan surnamed the Qarmati was the convert chosen to act as head of the branch founded near Kufa, and he seems to have been diligent in sending out missionaries throughout the whole district of Sawad, where success was easy as the oppressed Nabataean villagers were still groaning under the tyranny of the Arab colonists of the two camp-cities, Kufa and Basra. Not only were the peasants won over in large numbers, but many of the dissatisfied Arab tribes were also gained : these, it will be understood, were those tribes which had had no share in the wealth acquired by the Khalif and his followers. At first Hamdan required each proselyte to pay a piece of silver, corresponding to the fitr or legal alms which Muslims are expected to pay at the end of Ramadan. Then he exacted a piece of gold from each person on attaining the age of reason, a tribute which he called hijra or "flight," perhaps because intended for the maintenance of a place of refuge called the "house of flight." Later again he demanded seven pieces of gold which he termed bulgha or "livelihood." He prepared a choice banquet, and gave a small portion to each of those who gave him the seven pieces of gold, saying that it was the food of the dwellers in paradise sent down to the Imam. He next levied a fifth of all their possessions, basing his claim on the words of the Qur'an, "And know ye, that when ye have taken any booty, a fifth part belongeth to God and to His Apostle" (Qur. 8, 42). Next he required them to deposit all their goods in a 
common fund, a reminiscence of the communism taught in pre-Islamic times by the Persian prophet Mazdak, and justified this by the passages, "Remember God's goodness towards you, how that when ye were enemies, He united your hearts, and by His favour ye became brethren" (Qur. 3, 98), and "Hadst thou spent all the riches of the earth, thou couldst not have united their hearts; but God hath united them, for $\mathrm{He}$ is Mighty, Wise" (Qur. 8, 64). He told them that they had no need of money because everything on earth belonged to them, but he exhorted them to procure arms. All this took place in the year 276 .

The $d a^{\prime} i$ chose in each village a man worthy of confidence, and in his charge they placed the property of the inhabitants. By this means clothes were provided for those who were without, and all had their needs supplied so that there was no more poverty. All worked diligently, for rank was made to depend on a man's utility to the community; no one possessed any private property save sword and arms. Then it is said the $d a^{\prime} i$ assembled men and women together on a certain night, and encouraged them to indulge in promiscuous intercourse. After this, assured of their absolute obedience, he began to teach them the more secret doctrines of the sect, and so deprived them of all belief in religion, and discouraged the observance of external rites such as prayer, fasting, and the like. This was the distinctive mark of the Qarmatian branch: the initiated were no longer a small minority living in the midst of their fellow sectarians who still adhered to the external forms of Islam, but amongst the Qarmatians all were initiated to the fullest extent in all the teachings of the sect. Before long they began to steal and to commit murders, so that they produced a reign of terror in the vicinity. Then the da'is felt that the time was ripe for open revolt, and selected a village in the Sawad called Mahimabad, near the river Euphrates, and within the royal domain as their rallying place or " house of flight" : thither they carried large stones, and in a short time surrounded it with a strong wall and erected a building in the midst, in which a great many persons could be assembled and where goods could be stored. This took place in 277 . At this time the Khalifate was weak, and this 
favoured the lawless movements of the villagers who now came to be known as Qarmatians from their leader. Their head, Hamdan the Qarmati, meanwhile kept up constant correspondence with the leaders of the sect at Salamiya. After the death of Ahmad his son and successor wrote a letter to Hamdan, but he was not satisfied with its contents: he observed that this letter differed considerably in expression from those which he had previously received, and contained matters which did not seem to agree with the teaching he had received, so he concluded that the responsible heads had changed their policy. To make sure he sent a trusty follower named Abdan to Salamiya to find out how matters stood. Abdan arrived there, learned about the death of Ahmad and the succession of his son Husayn, and had an interview with this latter. In that interview he asked who was the Imam to whom they owed obedience, and Husarn replied by the counter question, " Who then is the Imam?" Abdan replied, "It is Muhammad the son of Isma'il the ron of Ja'far, the master of the world, to whose obedience your father called men, and whose huija he was.' Husayn showed some annoyance at this reply, and said: "Muhammad the son of Isma'il has no rights in all this; there has never been any other Imam than my father who was descended from Maymun b. Daysan, and to-day I take his place." By this reply Abdan discovered the real nature of the sect, or at least its present policy. He then returned to the Qarmati and told him what he had discovered, and by his orders all the $d u^{\prime}$ at were called together and informed of what Abdan had discovered and advised to stop their propaganda. As a result the preaching came to an end in the districts about Kufa, but they were not able to check it in remoter parts, and they ceased all correspondence with the leaders at Salamiya.

Then one of the sons of Ahmad who had been on a visit to Talakan tried to see the Qarmati on his return journey, but was unable to find him. He therefore called on Abdan and reproached him for ceasing to correspond with Salamiya. Abdan replied that he had left off preaching and desired to sever his connection with the sect as he had discovered that they were not really loyal to the house of 'Ali, but were supporting 
an Imam of the family of Maymun : he only asked God's pardon for what he had previously done in error. When the visitor saw that he had nothing to hope from Abdan, he turned to another $d a^{6} i$ named Zaqruya $b$. Mahruya and discussed with him Abdan's attitude. Zaqruya received him well, and it was agreed that he should be established as chief $d a^{6} i$ in the district and, in return would resume the former relations with Salamiya. To this Zaqruya assented, but objected that, so long as Abdan was alive all efforts would be fruitless, as all revered him as a leader. They agreed therefore to get rid of Abdan. For this end Zaqruya collected a number of his neighbours, informed them that the hujja or earthly representative of the Imam was dead, and that his son was now occupying his place. The people expressed the greatest respect towards the new hujja, and declared their readiness to carry out his commands. He told them that they were to kill Abdan as he had proved to be a rebel and apostate. Next night Abdan was killed. When, however, it came to be known that it was Zaqruya who had brought about his death the Qarmates were indignant, and Zaqruya had to flee for his life and hide himself, and advised the representative from Salamiya who seems to have remained with him, to leave the neighbourhood. This took place in 286 .

During the rest of that year, and the year following, the Qarmatians were busy hunting for Zaqruya who was compelled to move from place to place, and finally retired to a subterranean retreat. When he went into the village near his hiding place a woman who lived in the house used to make bread on the stone which covered the entrance to the concealed cave so as to disarm suspicion.

In 288 the search seemed to be relaxed, and then Zaqruya sent his son Hasan to Syria with a companion named Hasan b. Ahmad, and told them to preach to the Arabs of the $\mathrm{B}$. Kalb tribe, inviting them to recognise Muhammad b. Isma'il as the Imam. These two envoys obtained many followers. The envoy who had made plans with Zaqruya had meanwhile gone back to Talakan, and now, annoyed at Zaqruya's silence, went to the Sawad and discovered his place of concealment. IVhen Zaqruya told him of the success of his mission 
to the Arabs he was delighted and determined to join the envoys himself. Zaqruya approved this plan and sent with him his nephew Isa b. Mahwayh, surnamed Mudatthar, and another young man surnamed Mutawwak, at the same time writing a letter to his son bidding him render obedience to the leader of these new comers whom he termed Sahib al-Nakat. When they reached the $\mathrm{B}$. Kalb they were welcomed and received with every profession of loyalty, and the tribe prepared for war. This took place in 289. The resulting conflict with the authorities was, however, unsuccessful: the sectaries were not able to repeat their brigandage which the weakness of the central authority had been unable to prevent about the Sawad, and the leader, the kinsman of the Mahdi at Salamiya, was killed, and the Arabs scattered.

Nuwayri says that this leader had struck money, both gold and silver, and that the coins were inscribed on one side: "Say, the truth has come and falsehood has disappeared " (Qur. I7, 83): and on the other : "There is no God but God; Say, "for this I ask no wage of you, save the love of my kindred' ', (Qur. 42, 22).

After this leader's death Hasan, son of Zaqruya, took command of the Qarmatians and assumed the name of Ahmad. The general Muhammad b. Sulayman had a great victory over him and, as he was unable to reconstruct his forces, he left for Baghdad where, he said, he had many. followers, and put his son Kasam in charge as his deputy, promising to write to him. This was, however, only a pretext as he intended to seek safety in flight, but was caught by Mudatthar and Mutawwak and put to death.

This check caused the Arabs to keep quiet for some time. Then they received a letter from Zaqruya saying that he had heard of the death of Hasan and Isa by revelation, and that after their death the Imam was going to be revealed and would triumph with his followers. Kasam was now getting anxious, and thought it well to visit his grandfather Zaqruya in the Sawad; but Zaqruya disapproved the course of events and rebuked him severely, sending another disciple, an ex-schoolmaster named Muhammad b. Abdullah, to replace him. At first this new commander met with success, then came reverse and he was killed. At this 
news Zaqruya sent back Kasam to collect the remnants of the party which he did and brought them to adDerna, a village in the Sawad. Here they were joined by Zaqruya, who was hailed by the Arabs as their wali, and all the Qarmatians in the Sawad came out to join them. The rising in the Sawad was a mere jacquerie of Nabataean peasants, and the Qarmatian movement proper never rose much above this level. At the head of his men Zaqruya attacked the caravan of pilgrims on their way to Mecca in 294, plundered it, and slew twenty thousand pilgrims. The Khalif then sent out forces to put down these troublesome brigands, the Qarmatians were severely punished, Zaqruya was taken prisoner and sent in chains to the Khalif, but died of his wounds on the way (Abu l-Feda: Ann. Mosl., ii. 299).

In 295 a man named Abu Khatam founded a new sect of Qarmatians in the Sawad, and these were known as the Buraniyya after Burani, who was the most active $d a^{\prime} i$ in organising them. Abu Khatam forbade his followers to use garlic, leeks, or radishes, and prohibited the shedding of any animal's blood; he made them abandon all the religious observances of Islam, and instituted rites of an entirely new character. We shall find these prohibitions of particular vegetables in the ordinances of the Fatimid Khalif Hakim later on, but there justified by certain Shi'ite theories. At the end of the year Abu Khatam drops out of sight entirely. The movement is of interest only in showing the tendency of the Isma'ilians to form new schisms.

Another off-shoot of the Oarmatians established itself in the Bahrayn, the land between the Tigris and Euphrates. In 28I Yahya, a son of the Mahdi, whom de Sacy supposes to have been the same individual who advised Zaqruya and who was killed near Damascus in 289 , the one of whom we have already heard as the Sahib an-Nakat, although no mention of his real name is given in any account of Zaqruya's rising, came to al-katif and lodged in the house of a Shi'ite called 'Mli b. Ma'li b. Hamdan. He told his host that he had been sent by the Mahdi to invite the Shi'ites to recognise him, the representative of Isma'il. as the Imam, and to announce that the public appearance of the "concealed one" was near at hand. "Ali 
gathered together the Shi'ites of the locality, and showed them the letter which Yahya had given him to be read to them : they promised obedience and declared themselves ready to take up arms as soon as the Mahdi's representative appeared amongst them. Very soon all the villagers of the Bahrayn were induced to join in these undertakings. Yahya then went away and returned with a letter, which he stated that he had obtained from the Mahdi authorising him to act as their leader, and calling on them to pay him six pieces of gold and two-thirds for each man. This they did, and then Yahya brought a new letter bidding them give him a fifth of all their goods, and this they did also.

Ibn al-Athir says that Yahya went to the house of Abu Sa'id al-Jannabi, one of these Shi'ites, and that his host gave him food, and then told his wife to go in to Yahya and not refuse him her favours. News of this, however, came to the governor of the town, and he had Yahya beaten and his hair and beard shorn off as a punishment for the scandal caused. After this Abu Sa'id fled to his native town of Jannaba, and Yahya went out to the Arab tribes of Kalab, Oqayl, and Haras, who rallied round him, so that he found himself at the head of a considerable force in 286 . It will be noted that the desert tribes, even though the most purely Arab, were always ready to join revolutionary movements, anti-Arab as well as other; in fact they were simply marauders, and fell in with any plans which offered promise of a period of successful brigandage, irrespective of any political or religious movements involved.

Nuwayri supposes either that Abu Sa'id had previously learned Qarmatian ideas in the Sawad, or had been initiated by Hamdan and appointed $d a^{\prime} i$ for the district of al-Katif. Most of his followers were drawn from the lowest classes, butchers, porters, and such like. The Sharif Abu 1-Hasan says that Abu Sa'id regarded the $d a^{\prime} i$ Zaqruya as a rival and felt a jealousy towards him, so that, having contrived to get Zaqruya into a house belonging to him, he starved him to death.

When he had gathered a considerable following $\mathrm{Abu}$ Sa'id established himself at the town of al-'Ahsa, besieged Hajar, the capital of the Bahrayn, for a matter of two years, during which his followers were 
considerably increased, and finally captured the town by cutting off its water supply. Some of the inhabitants escaped to the islands in the river near by, others embraced Abu Sa'id's doctrines, whilst others were put to death. The town was pillaged and ruined, and thus al-'Ahsa afterwards replaced it as the capital of the Bahrayn. According to Ibn Khillikan Abu Sa'id first appeared as kabir or "great man" of the Qarmatians in 286 . In 287 they made an attempt on Basra, and though they defeated the forces sent by the Khalif to repel them, they were unable to take the city (Ibn Khall., i. 427).

Abu Sa id then attempted to get possession of Oman, but was obliged to abandon this scheme. He was slain in 301 with several other Qarmatian leaders, and was succeeded by his son Abu l-Kasam Sa'id, who held the leadership until his second son Abu Tahar, who had been designated successor, was old enough to take up the task, which happened in 305. The Qarmatian risings which take a position of considerable prominence in later history all took place under the successors of $\mathrm{Abu} \mathrm{Sa}^{\prime}$ id, who may be regarded as the founder of the Qarmatians as a revolutionary force, although there had been an earlier beginning of the sect as an off-shoot of the Isma'ilians under Hamdan and his missionaries.

According to Ibn Khillikan Abu Sa'id entered Syria in 289 , and in 291 he was slain in his bath by one of his eunuchs. He left six sons. It was Abu Tahar who marched on Basra in 311 , occupied it without serious resistance, and plundered the city. But to these doings of the Qarmatians we shall return later. 


\section{IV}

\section{ESTABLISHMENT OF THE FATIMIDS IN NORTH AFRICA}

THE political career of the Fatimids centres in North Africa and Egypt, and commences with the activity of Ibn Hawshab, who himself never visited those parts. This man, whom Maqrizi calls Abu 1-Kasam Hasan b. Farash b. Hawshab, and Abu 1-Fera and Bibars Mansuri, refer to as Rustam b. Husayn b. Hawshab b. Zadam an-Najjar (" the carpenter "), was a follower of Ahmad whom we have seen as succeeding his father 'Abdullah, and accompanied him on a pilgrimage to the sacred sites of the Shi'ites, the tombs of Hasan and Husayn and of several of the later Imams, all in the neighbourhood of Kufa and Samarra,- 'Ali's own tomb is not known for certain, but is commonly believed to be at Najaf, near Kufa. Whilst there they noticed a wealthy Shi'ite of Yemen named Muhammad himself remarked by his tears and display of grief (Maqrizi i. 349). According to this Yemenite's own account he had just read the Sura of "The Grotto" (Qur. I8), when he noticed an old man with a young companion close at hand. The old man sat down, his companion sat near, but kept on observing Muhammad, until at last he left the old man and drew near him. Muhammad asked him who he was; he gave his name as Husayn, and hearing this sacred name Muhammad could not restrain his tears. The old man observed this very attentively, and bids the young man ask him to join them. When Muhammad did so he asked who and what he was. The man replied that he was a Shi'ite, and gave his name as Hasan b. Faraj b. Hawshab. The old man said that he knew his father, and that he was a "Twelver." Did the son hold the same views? Hasnn replied that he always had held 
them, but that of late he had felt much discouragement (cf. extract in Qatremére, Journal asiatique, for Aug., 1836). From this a conversation commenced, and as a result Hasan was converted to acceptance of the Isma'ilian creed. Further, Ahmad drew the conclusion that Yemen would offer a promising field for Shi'ite propaganda, and decided to send Ibn Hawshab to act as dai in Yemen, and about A.H. 270 (=A.D. 883) he appears there as settled in the district of the B. Musa tribe at Sana (Maq. i. 349). At first he claimed to be simply a merchant, but his neighbours soon penetrated his disguise and urged him to act openly as a Shi'ite missionary who, they assured him, would be in every way welcome (Bibars Mansuri). Thus encouraged he declared himself a Shi'ite agent, and soon gathered a considerable band of followers drawn, not only from the immediate vicinity, but also from the Qarmatians of Mesopotamia. As soon as they were strong enough Ibn Hawshab's companions took up arms and began raids upon neighbours who had not accepted the Shi'ite creed and met with much success in obtaining plunder.

From the earliest period of Muslim history North Africa has been the favourite field of exploitation of every sect and political party which found itself in opposition to the official Khalifate, and there has always been very close intercourse between that area and South Arabia; indeed, there are even common peculiarities of dialect between the two. Thus we find that as soon as the new Isma'ilian sect was established in Yemen, Ibn Hawshab sent two missionaries, Hulwani and Abu Sufyan (Maq. ii. Io) to preach in the province of Ifrikiya, the modern Tripoli and Tunis, where their work seems to have lain particularly amongst the aboriginal Berber population, for the Berbers were always more disposed to any heresy or rebellion which would give them a good pretext for making war against the ruling Arabs. Nothing is known of the subsequent history of these two missionaries save that after a brief career during which they seem to have made a deep impression, especially on the Katama tribe, they died. This Katama tribe lived in the broken territory north-west of the town of Constantine, in what would now be north-east Algeria. 
As we shall have to refer more than once to the geography of North Africa it will be convenient here to make a brief statement of its political divisions and condition in the fourth century A.H. By North Africa we understand the whole territory lying between the land of Egypt on the east and the Atlantic on the west, bounded by the Mediterranean on the north and by the great desert on the south. Previous to the Arab invasion this land was inhabited by the Berbers or Libyans, the same who, under the name of Lebu, had constantly threatened Egypt in the days of the Pharaohs. As a race these Berbers seem to have progressed little since neo-lithic times, and were still in the condition of nomadic tribes like the Arabs of the pre-Islamic period. Their language was not Semitic, but it has many very marked Semitic affinities and, although language transmission is often quite distinct from racial descent, it seems quite probable that in this case the race bore a parallel relation to the Arab stock. This would be best explained by the supposition that both were derived from a neo-lithic race, which at one time spread along the whole of the southern coast of the Mediterranean and across into Western Asia, but that some cause, perhaps the early development of civilization in the Nile valley, had cut off the eastern wing from the rest, and this segregated portion developed the distinctive characteristics which we term Semitic.

Along the coast there had been a series of colonies, Greek, Punic, Roman, and Visigothic, but these left no permanent mark on the Berber population, language, or culture. Although at the time of the Arab invasion the country was theoretically under the rule of Byzantium', and the invaders had to meet the resistance of a Greek army, the early defeat of the Greeks brought an immediate end to Greek influence in the country, and left the Arabs face to face with the Berber tribes.

The Arab invasion of North Africa followed immediately after the conquest of Egypt, but the internal disputes of the Muslim community prevented this invasion from resulting in a regular conquest, much less in settlement. It was not until the second invasion took place in A.H. $45(=$ A.D. 665) that we can 
regard the Arabs as really beginning the conquest of the country and its settlement. For centuries afterwards the Arab hold was precarious in the extreme, and many Berber states were founded from time to time, some of which had an existence of several centuries. As a rule there was a pronounced racial antipathy between Arab and Berber, but this was mild compared with the tribal feuds between different Berber groups, and Arab rule was only possible by temporary alliance with one or other of the quarrelling factions. Strangely enough the religion of Islam spread rapidly amongst the Berbers, but it took a peculiar development which shows the survival of many pre-Islamic religious ideas and observances. The worship of saints and the reverence paid to their tombs is a corruption of Islam which appears in most lands, but in the West it takes an extreme form, although there are tribes which reject it altogether. Similar worship, often in a revolting form, is paid to living saints or murabits (marabouts), who are allowed to indulge every passion, and to disregard the ordinary rules of morality: very often these reputed saints are no more than insane persons, for the Berbers, like many other primitive people, regard insanity as a form of divine inspiration. Such saints, even those living to-day, are credited with miraculous powers, and especially with the power of surpassing the limitations of time and place, and so to pass from one place to another in an instant of time, and to be in two places at once.

These ideas, of course, are no legitimate development of Islam, to which they are plainly repugnant, but represent the survival of older pagan beliefs which Islam has not been able to eradicate. At the same time, as we have noted, there are tribes which are completely free from these ideas, and there is, especially in the towns, an element which is strictly orthodox in its rejection of alien superstitions, and there have been many learned theologians and jurists of the Berber race, for the most part of a reactionary and conservative school of thought. The conquest of Spain was carried out by Muslims, amongst whom the Berbers were in the numerical majority, and the Berber element always predominated in Spain, where some of the most 
brilliant philosophy, literature, and art of the Islamic world was produced.

North Africa was always the home of the lost causes of Islam. Whenever the Khalifs of Baghdad tried to exterminate some obnoxious sect or dynasty, the last survivors took refuge in the remoter parts of the West, and there managed to hold their own, so that even now those parts show the strangest survivals of otherwise forgotten movements. But North Africa always gave its readiest welcome to those sects which show a strongly puritan character: though anyone in revolt against the Khalif or other recognized authority could count on a welcome in North Africa for that very fact.

In race, language, and religious ideas the Berbers of the North are one with the Berber tribes of the great desert which spreads to the watershed of the Benwe and connects, by regular trade routes following the ridges which traverse North Africa from north-west to south-east, with the Horn of Africa. But these desert dwellers of the south do not enter into the subject of our present enquiry.

The Arab conquerors settled along North Africa and down to the desert edge in sporadic groups, their tribes as a rule occupying the lower ground, whilst the older population maintained itself in the mountainous districts. But this does not mean that the Berbers were held at bay as a subject people: the Katama, for instance, possessed some of the best territory in North Africa, and were practically independent of the Khalif. During the invasion of 45 the city of Kairawan was founded some distance south of Tunis. The site was badly chosen, and it is now little more than a decayed village, but for some centuries it served as the political capital of Ifrikiya, the province which lay next to Egypt and embraced the modern states of Tripoli, Tunis, and the eastern part of Algeria to the meridian of Bougie. West of this lay Maghrab or "the western land" which was divided into two districts, Central Maghrab, extending from the borders of If rikiya across the greater part of Algeria and the eastern third of Morocco, and Farther Maghrab, which was the land beyond to the Atlantic coast.

The Berber tribes were spread over all these provinces. In the eastern part of Ifrikiya the chief were 
the tribes of Hwara, Luata, Nefusa, and Zuagha: in Central Ifrikiya the Warghu and Nefzawa: in western Ifrikiya the Nefzawa, Katama, Awraba, and a number of smaller tribes to the south: the chief tribes of Central Maghrab were the Zuawa (or Zouaves), Magbrawa, and B. Msab: and in Farther Maghrab the B. Wanudin, Ghomara (in the $\mathrm{R}$ if of Morocco), the Miknasa, etc. No satisfactory result has ever been attained by those who have tried to identify the ancient Numidians, Mauritanians, and Gaetuli with existing tribes; evidently, as in Arabia, there have been new groupings and new formations, which forbid the tracing back of the mediaeval tribal divisions to ancient times; perhaps it was Islam which finally rendered permanent the divisions as they existed in the first century of the Hijra. Amongst these Berber tribes were spread the tribes of Arab invaders and settlers which, even in the Ioth century A.D. extended in scattered groups from the borders of Egypt to the Atlantic. For the most part each race preserved its own language, the Arabic dialects being distinguished by archaic forms, and a phonology somewhat modified by Berber influences; but there are several instances of Berber tribes which have adopted Arabic, and some of Arabs and mixed groups which have adopted the Berber language. For the most part the Arabs have had no reluctance to mingle with the Berbers, but the attitude of the Berbers varies, and some groups rigidly exclude intermarriage between themselves and the Arabs or any others.

The Kharijites, the oldest and most turbulent dissenting sect of Islam, the reactionaries who opposed the modification of Muslim customs under Hellenistic influence, had appeared in Maghrab early in the 2nd century of the Hijra after their suppression in Asia, and were still a living force there in the fourth century, when their very name was almost forgotten elsewhere. A small group of the less extreme branch of that sect, the Ibadites, still survives in strict isolation in South Algeria. The Idrisids, a dynasty descended from the house of Hasan the son of "Ali, founded by Idris who escaped from the attempted extermination of his kinsmen at Madina in 169 , ruled an independent state in Farther Maghrab in the fourth century. The 
Umayyads dethroned by the 'Abbasids in 132, had a representative who escaped to North Africa, and then crossed to Spain where they founded a Khalifate at Cordova which, in the fourth century, had become a great and flourishing power. Indeed the Maghrab was too remote from the Khalifs of Baghdad ever to be under effective control: one after another punitive expeditions marched across North Africa, the disaffected were defeated, the remnant took refuge in the hills, and in the course of a few years or even months the former condition returned again. Obviously those western lands offered a promising field to the agitator, whether political rebel or sectarian leader, and Ibn Hawshab's missionaries had evidently struck a promising vein in the Berber tribe of Katama.

Amongst those who attached themselves to Ibn Hawshab in Yemen was a certain Abu 'Abdullah Hasan (or Husayn) b. Ahmad b. Muhammad b. Zakariya, afterwards surnamed ash-Shi'i, a native of Sana and a zealous Shi'ite who had been inspector of weights and measures in one of the districts attached to Baghdad. He was a man not only of superior education and intelligence, but astute and with as good knowledge of how to deal with men. Before long he became one of Ibn Hawshab's most trusty companions and, when the news came of the death of the two missionaries who had been sent to Africa, Ibn Hawshab determined to send him as $d a^{6} i$, and provided him with the funds necessary for his enterprise. Later on we find him in Africa assisted by his brother, but we are without information as to whether this brother was sent to join him later or set out with him (Maqrizi ii. I , Ibn Khallikan i. 465).

Abu 'Abdullah's first step was to go to Mecca and to find out where the Katama pilgrims were lodged. As soon as he discovered this he engaged a lodging near by and sat as close to them as he could, listening to their conversation. Before long they began to talk about the prerogatives of the house of 'Ali, a subject on which they had been instructed by the two missionaries who had already visited their country, and Abu 'Abdullah joined in their conversation. When he stood up to go away they begged to be allowed to visit him, and to this he assented. They were delighted with 
his learning and began to frequent his society, and one day they asked him where he intended to go when he had finished his pilgrimage to Mecca. He replied that it was his intention to go to Egypt, so they begged him to join them as they would have to pass through Egypt on their homeward journey. They set out together, and the good opinion they had formed of him was greatly increased as they observed his piety, his regularity in the exercises of religion, and his ascetic character. During all this time he mentioned no word of his real intentions, but constantly directed the conversation to the subject of the land of Katama, and asked many questions about the neighbouring tribes and their relation with the governor of Ifrikiya. On this last subject the Katamites explained that they did not regard the governor as having any authority over them, his residence was ten days' journey from their country, and his control was nil. He further enquired if they were accustomed to bear arms, and they replied that this was their usual occupation.

When they reached Egypt Abu 'Abdullah said farewell to the Katama tribesmen but, as they expressed deep regret at the idea of leaving him, they asked what business he had to attend to in Egypt. He replied that he had no business there but simply intended to become a teacher. "If that is all," they said, " our country will offer you a better field, and you will find more who are disposed to become your pupils, for we know your worth." So as they pressed him warmly, he consented to continue in their company, and went on until they met some of their fellow tribesmen who came out to meet them. All these had come under the influence of the two former missionaries and were devoted Shi'ites and, when they heard the account given by the returning pilgrims, they welcomed $\mathrm{Abu}$ 'Abdullah with every demonstration of respect.

At length, about the middle of Rabi" I. 288 (Feb., 900 A.D.) they reached home, and every one of his companions pressed the missionary to be his guest. He declined all these offers of hospitality and asked them to inform him where was the valley of al-Khiyar (the righteous men). This enquiry greatly astonished them as no one could remember that such a name had ever been mentioned in his presence: they admitted, 
however, that there was such a place and described its situation, and he then told them that he would take up his abode there and visit each of them from time to time. He then set out with some guides to Mount Inkijan where the valley is situated, and when they arrived there he told his companions, "Here is the 'Valley of the righteous men' and it is on your account that it is thus named, for one reads in the traditions that 'the Mahdi will be obliged to make his migration, and will be helped in his flight by the Righteous Men who will be on earth at that time, and by a nation whose name is derived from kitman'; it is because you will rise up in this valley which has been named "The valley of the Righteous Men,", (Maq. ii. II). The derivation of the Berber name Katama from the Arabic kitman "secret" was, of course, no more than a play upon words.

Very soon the dwellers in the vicinity began to spread Abu 'Abdullah's reputation, men came from all parts to visit him, and he comletely swayed a large body of Berber tribesmen amongst whom the Katama tribe was most prominent. $\mathrm{He}$ made, however, no further mention of the Mahdi, and did not seem to interest himself in the subject. But he connected his work with that of the two former missionaries and said : "I am the man entrusted with the sowing of whom Abu Safyan and Hulwani spoke to you," and this increased their attachment towards him and his importance in their eyes (Maq. id. 37). Some, however, regarded him with disfavour, for evidently there were Berber tribes which had not adopted Shi'ite doctrines: but the Katama tribe under its chieftain Hasan b. Harun supported him, and took up arms against those who tried to interfere with his work. This inter-tribal dispute was the beginning of a long conflict, which ultimately made the Shi'ites dominant in North Africa. Supported by the Katama and a number of Kabyle tribes Hasan attacked and catured the town of Tarrut, and then advanced against Meila.

Already reports of the religious teacher of Mount Ankijan had spread through the province of Ifrikiya, and had reached Ibrahim b. Ahmad the Aghlabi Emir. These Aghlabids were hereditary governors of Ifrikiya established at Kairawan about 184 by the 'Abbasid 
Khalifs, to whom they paid tribute and were subject. Desirous of obtaining more accurate information Ibrahim had sent to the governor of Meila to make enquiry about $\mathrm{Abu}$ 'Abdullah and his doings, but the governor had sent back to Kairawan a somewhat contemptuous account of him, in which he was described as a religious fanatic, a devotee revered as a saint by the ignorant people, and so the political possibilities of his activity were overlooked.

The taking of Tarrut and the advance on Meila, which city, after a brief resistance, was betrayed by some of its inhabitants, made a change in this attitude. Ibrahim sent an army under his brother Ahwal against Abu 'Abdullah and his followers, and defeated them, after which Ahwal returned home fully convinced that the rising had been finally disposed of. From this defeat $\mathrm{Abu}$ "Abdullah retired to Mount Ankijan where he established a " house of flight," and there he gathered his partisans around him. As soon as he heard of Ahwal's retirement he began a series of forays, pillaging the surrounding districts and annoying those who did not join the Shi'ite sect. At this Ahwal made a new expedition, but this time he suffered a repulse, not severe enough to force him to retreat, but compelling him to be satisfied with a defensive police duty in the neighbourhood which was, however, effectual in checking the Shi'ite raids. But this did not last long. In 291 (=A.D. 903) Ibrahim the Aghlabi died, and the governorship passed to his son Ziadat Allah, a man indolent ind entirely devoted to pleasure, who recalled his brother Ahwal from his military duties.

This, of course, opened new opportunities for Abu 'Abdullah, and very soon his followers were ranging at will through the whole province of Ifrikiya, and he boldly declared that the Mahdi was now near at hand and would soon appear in Africa, and would prove his sacred mission by working miracles (Maq. ii. II). Common report affirmed that Abu 'Abdullah himself had done many wonders, even making the sun rise in the west, restoring the dead to life, and other marvels. Not only had he now a very large following amongst the Berber tribesmen, but many of the officers serving under Ziadat Allah were well disposed towards the 
Shi'ite claims, and were secretly in correspondence with Abu 'Abdullah.

At this juncture, in $29 \mathrm{I}$, the Shi'ites were practically supreme in all the country west of the suburbs of Kairawan, and now $\mathrm{Abu}$ 'Abdullah sent messengers over to the Mahdi inviting him to cross into Africa. Isma'il had just died at Salamiya, and shortly before his death advised his son $\mathrm{Sa}^{\text {'id }}$ to migrate to a distant land. As soon as his father died Sa'id and his son Abu 1-Kasam Nizar set out from Salamiya intending to go to Yemen, but hearing of the success in North Africa changed their course in that direction, probably meeting the messengers from Abu 'Abdullah on the way (cf. Ibn Khaldun ii. 5I5-5I6). The journey was beset with great perils, especially in the passing through Egypt. At that time the governor of Egypt was Abu Musa Isa b. Muhammad Nushari, who had been appointed after the death of Ibn Tulun in 292, and held office until the government was usurped by Khalanj in 293-4, after which the Khalif al-Muqtadi restored him to office which he held until his death in 297. Sa'id, or Ubayd Allah as he now preferred to call himself, arrived during this latter period of office, and the governor had grounds of suspicion about him without very clear information. The refugees left Misr, the old capital lying to the south of the present Cairo, but the governor followed and overtook them. He attempted no violence, but joined their company and induced them to rest with him in a garden, his guard meanwhile surrounding the place. I'e tried every means to win their confidence, and so to find out who they were and what was the object of their journey : he tried to coax 'Ubayd Allah to join him in taking refreshment, but 'Ubayd Allah declined on the pretext that he was then observing a fast: then he tried to get information by judicious questions, but in vain. At length he allowed 'Ubayd Allah to go on his way. He offered the travellers an escort, but this was politely declined. Then the governor assembled his men to return home, but many of them showed their discontent that the travellers had been allowed to escape, and on second thoughts the governor himself regretted that he had not detained them for furher enquiry, and sent a body of men after them, but they had made good 
use of their start, and it proved impossible to overtake them: Some said that the governor had been bribed by 'Ubayd Allah, and this seems to be likely enough.

After this escape 'Ubayd Allah, his son, and Abu 1-'Abbas, the brother of Abu 'Abdullah, went on to Tripoli. The next town on their way would be Kairawan, and 'Ubayd Allah was distinctly anxious about venturing there, so he sent forward Abu 1-'Abbas to obtain information. Now it appears that Ziadat Allah had much clearer grounds of suspicion than the Egyptian governor, and Abu 1-'Abbas was not able to escape suspicion, and was taken prisoner. Ziadat Allah does not seem to have been so much interested in the prisoner himself, but made every endeavour to find out some details about the companions with whom he was travelling. Abu 1-'Abbas denied that he had travelled with any companions, or that he had any knowledge of a fugitive from Syria: he asserted that he was simply a merchant passing through If rikiya on his own business. But Ziadat Allah's suspicions were not allayed: Abu 1-'Abbas was detained in custody, and a messenger was sent to Tripoli to secure the arrest of the other travellers. The messenger, however, returned with the reply that 'Ubayd Allah had already left the city before the order for his arrest had arrived. Again the suggestion is made that the governor of Tripoli had been won over by bribes. It is supposed that 'Ubayd Allah had been able to take with him a great part of his considerable wealth, and that it was easy for him to corrupt the provincial governors. Certainly he had information of what had befallen Abu 1-'Abbas in Kairawan. At first he retired to Kastilia, but when he made sure that there was no possibility of Abu 1-'Abbas getting free and joining him there, he went on to Sijilmassa (Maq. ii. I I).

At the time of his arrival in this town the ruling prince, al-Yasa b. Midrar, had no grounds of suspicion, and received the travellers very kindly. 'Ubayd Allah made him valuable presents, and they soon became intimate. One day, however, as they were sitting together, a letter from Ziadat Allah was put into al-Yasa's hand, and in it the Aghlabi related the suspicions he had formed about "Ubayd Allah. The governor immediately ordered the arrest of 'Ubavd 
Allah and his son, questioned them closely about their relations with Abu l-'Abbas, and the suggestion that they were in some way associated with $\mathrm{Abu}$ 'Abdullah, but 'Ubayd Allah denied any knowledge of either of these. The father and son were then separated and confined in separate quarters, and the son, Abu 1-Kasam, was examined apart, but no information of any sort could be obtained from him.

Meanwhile, since the departure of the messengers from Abu 'Abdullah to 'Ubayd Allah, the former had continued his career of conquest. Meila, Satif, and other towns immediately near the Katama territory were taken, and the governor at Kairawan was no longer able to disguise from himself that the Shi'ite revolt was threatening the very basis of Arab authority in Ifrikiya. Under these circumstances Ziadat Allah assembled a council of canonists to advise him about the Shi'ite claims. The meeting took place in the house of the prince's chief adviser, Abdullah b. Essaig, and, after considering the religious character of Abu 'Abdullah movement, and especially the report that "he cursed the Companions," i.e., that he was a Shi'ite who cursed the first three Khalifs as usurpers who had excluded 'Ali from his rights, regardless of the fact that they had been the companions of the Prophet, they decided that Abu 'Abdullah and his followers must be publicly denounced as heretics. Fortified with this decision which was necessary to stop the tendency of his own people to favour the Shi'ites, the Aghlabid assembled an army of 40,000 men whom he placed under a kinsman named Ibrahim b. Habashi b. 'Umar at-Tamimi, and sent them against the Katama Ibrahim took up his quarters at Konstantina 1-Hawa, on the western edge of the Katama country, and there he stayed six months without actually attacking the Shi'ites, but serving as a check upon their movements. As soon as he appeared Abu 'Abdullah retired to his usual retreat, "the house of flight," and no further advance was made on either side. As Ahwal had already proved, this kind of patrol work was the most effective. But Ibrahim desired a decisive punishment of the revolted tribes, and rashly resolved to move out and attack Kerma, one of the cities occupied by the Shi'ites. On the way Abu 'Abdullah met and defeated 
him, and he had to flee with the remnants of his army to Kairawan.

Matters were now becoming extremely serious, and Ziadat assembled a new force which he entrusted to Harun b. Tabni. Harun marched upon Daralmoluk and took it, but immediately afterwards Abu 'Abdullah arrived with his main band, and a general engagement ensued, in which Harun was killed and his forces completely routed. After this victory Abu 'Abdullah marched upon Banjas, which capitulated, and then was in a position to threaten Kairawan itself. We have now reached the year 295, and at this point Ziadat Allah raised a third army and took command himself. He advanced to Elaris, but there his courtiers began to remonstrate with him : if any disaster took place and he were involved it would mean the downfall of the Aghlabid dynasty, a result which would not necessarily proceed from the defeat of a subordinate general. Persuaded by his entourage Ziadat Allah appointed his kinsman Ibrahim as commander-in-chief, and himself retired to Raqada to the south-west of Kairawan, and gave himself over entirely to a life of pleasure.

Meanwhile Abu 'Abdullah was extending his authority over the whole country. He was invited to Bagaya which he occupied, then took by force the small towns of Majana, Sash, and Maskanaya. His politic clemency at Bagaya produced a good impression, and did much to assist him in gaining over other towns. His success caused great alarm to Ziadat Allah, and he consulted 'Abdullah b. Essaig, who advised him to retire to Egypt and leave a general in charge of the army, but Ibrahim persuaded him to abandon this idea. Soon afterwards Abu 'Abdullah advanced to Merida, where were many refugees from the towns already taken. The inhabitants asked for terms, and $\mathrm{Abu}$ 'Abdullah's lieutenants agreed, the leader himself being absent. When the envoys from the citizens returned and the gates were opened to admit them, the attackiny army made a sudden rush, forced their way in, and pillaged the city.

Abu 'Abdullah now resolved to attack Raqada where Ziadat Allah was established. As he marched towards that town Ibrahim tried to intercept him, and for this purpose left al-Arbes where he was encamped, and 
occupied Derdemin, which lay near the route which $\mathrm{Abu}$ 'Abdullah would have to take. On his way the Shi'ites sent a detachment to take Derdemin, without apparently being aware that this was now Ibrahim's headquarters. The detachment was repulsed and put to flight. Abu 'Abdullah was unable to understand why the detachment did not return, and went after them with reinforcements to find out. On the way they met their comrades in full flight from Derdemin, but at (with the help of the new-comers inflicted a severe defeat their arrival the fugitives stopped, turned back, and on Ibrahim. This was followed by the submission of Qafra and Qastilia, the latter place being a general depot for Ziadat Allah's munitions, provisions, and money, all of which fell into the Shi'ites' hands. For the moment, however, Abu 'Abdullah refrained from further advance: he settled at Bagaya and established his headquarters there, and then retired for a time on his own account to Mount Ankijan.

Ibrahim then decided to take the offensive and laid seige to Bagaya, news of which quickly brought Abı 'Abdullah back from his retirement, bringing 12,000 newly enrolled tribesmen with him. But Bagaya was offering such a sturdy resistance to Ibrahim that the besieger was both astonished and discouraged, and, hearing of Abu 'Abdullah's approach, retired again to al-Arbes.

In the spring of the following year, A.H. 296, the two armies of Ziadat Allah and Abu 'Abdullah both took the field. The historians state that the former numbered 200,000 men, the latter many more. It must, of course, be remembered that figures of this sort by oriental writers are hardly deserving of the least attention. An engagement took place with results unfavourable to Ibrahim, who forthwith retired to Kairawan, the strongest military stronghold in Africa. As a consequence of this Abu 'Abdullah was enabled to enter al-Arbes, and a great massacre of the inhabitants took place, some 3,000 it is said being killed in the principal mosque. The following morning $\mathrm{Abu}$ 'Abdullah retired to Bagaya. Next day the news reached Ziadat Allah. For some time 'Abdullah b. Essaig endeavoured to conceal it from the citizens, but 
when he offered 20 dinars to each volunteer willing to serve in the cavalry, and to dinars to each recruit for the infantry, the citizens perceived that the state was reduced to the last extremities and a panic ensued, many of the nobles and their dependents leaving for Raqada. Ziadat Allah himself packed up his valuables, and with the favourite ladies of his harim set out for Egypt. 'Abdullah b. Essaig was put in charge of the prince's goods, and these were loaded on thirty camels, but unfortunately they missed their way as they started in the dark, and arrived at Susa where the governor impounded them, and they finally fell a prey to $\mathrm{Abu}$ 'Abdullah. 'Abdullah b. Essaig himself tried to escape by sea, but a storm drove his ship ashore at Tripoli just as Ziadat Allah, angry at missing his goods, was stopping there. The unfortunate minister was brought before the prince as a deserter, but made so good a defence that Ziadat Allah decided to pardon him; the courtiers, however, intervened, and he was beheaded.

After reaching Egypt, Ziadat Allah passed on to Rakka and sent forward messengers to the Khalif asking permission to present himself at Baghdad. A reply came forbidding him to attend at court and ordering him to await further instructions at Rakka. He stayed there a whole year which he spent in pleasure, and then received instructions to return to Africa, the governor of Egypt being directed to prepare supplies to equip him for an expedition against the Shi'ites. In accordance with these orders he travelled back to Egypt, where the governor told him to wait for the supplies at Dhatu 1-Hammam. He waited there a long time in vain, and then, as he was now in broken health he started out for Palestine, but was taken worse on the way and died at Ramla. With him the Aghlabid dynasty of hereditary governors of Ifrikifa, under the 'Abbasid Khalifate, came to an end.

When Abu 'Abdullah heard of the Emir's flight he went at once to Wady an-Namal, and sent forward I, ooo men under Arunaba b. Yusus and Hasan b. Jarir to Raqada. The news soon reached Kairawan, and a deputation was sent out to congratulate the Shi'ites. These emissaries thought to ingratiate themselves by making contemptuous and hostile reflections upon the 
late ruler, but $\mathrm{Abu}$ 'Abdullah rebuked them, stating that Ziadat Allah had lacked neither courage nor intelligence, but that defeat had overtaken him because it was the will of God. His gracious reception of the envoys from Kairawan caused great annoyance to the Katama tribesmen, to whom he had made a promise that they would be allowed to plunder the city.

In Rajab I. $296 \mathrm{Abu}$ 'Abdullah, at the head of 300,000 men, entered Raqada to find the town entirely deserted by its inhabitants. He established himself in one of the empty mansions, and the leaders of the Katama occupied others (Maq. ii. I I). He then sent to Tripoli to fetch his brother Abu 1-'Abbas and Abu Ja'far, as well as 'Ubayd Allah's mother, who had apparently accompanied her son, though we hear no more about her. Abu 'Abdullah was a fervent Shi'ite and established a strict puritan rule in Kairawan, death being the penalty for drinking wine or bringing it into the city. The Shi'ite formula was used in the call to prayer, which implied the addition of the words " come to the excellent work" to the orthodox call, and the names of 'Ali, Fatima, Hasan, and Husayn were inserted in the Khutba or public prayer at the Friday service. As in modern Persia the supreme authority was attributed to the concealed Imam, and the civil government based its rights on the claim to act as his deputy until the day of his revealing. In Kairawan the proper deputy would naturally be the Mahdi 'Ubayd Allah, but no public announcement was made of this as yet. The Khatibs of Kairawan and Raqada were ordered to omit the name of the 'Abbasid Khalif from the khutba, but no other ruler's name was inserted in its place. A new coinage was prepared, and this similarly bore no prince's name; simply it had the inscription on one side, "I have borne my witnes's to God," and on the other "May the enemies of God be scattered."

During these events 'Ubayd Allah remained still imprisoned at Sijalmasa, but now the time had arrived for his supporters to rescue him. Abu 'Abdullah's two brothers, Abu 1-'Abbas and Abu Zaki, who had hitherto taken no very prominent position, were left as deputies at Raqada, and Abu 'Abdullah with a large body of followers marched towards Sijalmasa. The 
object most desired was of course the liberation of 'Ubayd Allah, and the danger was that the governor might put him and his son to death before the Shi'ites could rescue them. It was necessary, therefore, to avoid irritating al-Yasa the governor. Abu 'Abdullah halted his army at some distance from the city, and sent forward envoys bearing a letter in which he assured al-Yasa that he desired no conflict, but only asked that 'Ubayd Allah and his son might be set free. Al-Yasa only threw the letter on the ground and had the envoys put to death. A second letter produced a similar result, and then $\mathrm{Abu}$ 'Abdullah advanced and camped his men before the city, intending to make an attack on the following day. During the night al-Yasa escaped with all his portable goods and relatives. Next morning the inhabitants sent out and informed Abu 'Abdullah, who went at once to the prison whence he liberated 'Ubayd Allah and his son. Leading the Mahdi out he showed him to the people, saying: "This is the Mahdi to whose obedience I invited men." He then set him and his son on horses and paraded them through the streets, crying, " This is your lord," frequently interrupting his cry with tears of joy. He conducted them to a tent which had been made ready for them, and sent a body of men in pursuit of al-Yasa (Maq. ii. II-I2). The fugitive governor was overtaken, brought back, and executed.

Ibn Khallikan gives another account of the taking of Sijalmasa, in which it is related that, before leaving the city al-Yasa executed 'Ubayd Allah, and when Abu 'Abdullah entered his cell he found only the dead body and a faithful Jewish slave. Knowing that the absence of the Mahdi would be fatal to the whole Shi'ite scheme, he seized the slave, compelled him to silent acquiescence, and leading him out declared, "This is the Mahdi" (Ibn Khall. ii. 78). This is another form of the "Jewish legend," to which we have already. referred (cf. 47 , above).

For forty days ' $U$ bayd Allah remained at Sijalmasa, and then, towards the end of Rabi' II. 297 he was conducted by Abu 'Abdullah to Raqada. Here he assumed the title of "al-Mahdi, Commander of the Faithful," and on the following Friday was prayed for under that title in the mosques of Raqada and 
Kairawan. On the same day the Sherif and the $d u^{\prime} a t$ held a public meeting, at which they tried to persuade the people of Raqada to become professed members of the Isma'ilian sect. In this, however, they were only partially successful, although lavish rewards were offered to those who joined, and many of those who definitely refused were imprisoned, some even put to death. In fact we are now in quite different surroundings : the Mahdi was a successful adventurer, and had every prospect of establishing a principality quite as stable, and more independent than that of the Aghlabids : the religious pretensions of the Shi'ite party were only an embarrassment. From this time forward the Isma'ilian sectaries form a privileged class, on the whole disliked and despised by the people generally, who were quite ready to submit to the Mahdi's government, though deriding its spiritual claims; and the tendency is for the ruler rather to disembarrass himself of the sectaries.

Ziadat Allah's harim was then presented to the Mahdi who, after selecting such women as met withi his approval for himself and his son, distributed the remainder amongst the chief men of the Katama.

As soon as 'Ubayd Allah had entered Raqada the citizens had waited on him to obtain the renewal of the amnesty accorded by $\mathrm{Abu}$ 'Abdullah. He replied to them, "Your lives and your children are safe." Thev asked him if he would give them a similar assurance as to their property, but this he refused. This caused great anxiety amongst the citizens, who gathered that their property was regarded as at the disposal of the Shi'ites. At first 'Ubayd Allah showed a much more violent Shi'ism than Abu 'Abdullah, although we seem justified in supposing that he was merely an adventurer who was entirely without religious convictions, whilst $\mathrm{Abu}$ 'Abdullah seems to have been a devout Shi'ite: but this is by no means the only instance in history where religious persecution was carried out most severely by unbelievers. He caused the "Companions," i.e., the three Khalifs preceding 'Ali, to be reviled openly, just as 'Ali himself had formerly been cursed publicly every Friday in the mosque of Damascus; and he strictly prohibited the canonists from teaching or using any system of juris- 
prudence other than that attributed to Ja'far as-Sadiq.

Year 298 (=A.D. 9ro). Abu 'Abdullah had proved himself a loyal and efficient helper, and had done more than any other to establish the Mahdi in Africa. It seems that he was a sincere Shi'ite, and acted throughout in perfect good faith and in attachment ito the Mahdi with whom he had corresponded, but probably had never seen before he entered the prison at Sijilmasa. In 298 these feelings changed. One account is that $\mathrm{Abu}$ 'Abdullah and the chiefs of the Katama began to feel doubts about the Mahdi's claim because he proved unable to work any miracles, and ability to perform miracles had always been assumed as one of the evidences of a Mahdi's claims. Working miracles always has been and still is the primary essential of a murabit (marabout) in North Africa, and there need be no reason to doubt that the non-fulfilment of the probably extravagant Berber expectations must have caused serious disappointment amongst the Katama. Then again, the Berbers, like the Arabs, are naturally fickle and insubordinate; in the ordinary course of things they would be sure to murmur before long against any ruler, especially against one near at hand. Did Abu 'Abdullah share their feelings? or did he excite them for his own ends? Ibn Khillikan states that when the Mahdi was firmly established at Kairawan, Abu 1-'Abbas reproached his brother that "You were master of the country and uncontrolled arbiter of its affairs, yet you have delivered it over to another and consent to remain in the position of an inferior," and at this $\mathrm{Abu}$ 'Abdullah began to regret that he had handed everything over to the Mahdi and commenced plotting against him (Ibn Khill. i. 465). But it must be remembered that Ibn Khillikan shows a very marked anti-Fatimid bias. It seems more likely that both Abu 'Abdullah and the Berbers were really disappointed to find the Mahdi an ordinary mortal. The matter was debated in the presence of the chief sheikh of the Katama, and Abu 'Abdullah expressed his doubts, saying: "His actions are not like those of the Mahdi to whom I used to try to win you : I am afraid I have been mistaken in him, and have suffered a delusion similar to that of Ibrahim al-Khalit when the night closed over him and he saw a star and said, 'This 
is my lord' (Qur. vi. 76). It is therefore incumbent on me and you to examine him, and to make him show those proofs which are known to the genealogists as those to be found in the Imam" (Arib b. Sa'id, Nicholson, pp. I20-I2I). As a result the Sheikh of the Katama waited upon 'Ubayd Allah and asked for the performance of a miracle as a proof of his claim to be the Mahdi. The reply was the immediate execution of the Sheikh. This gave serious alarm to Abu 'Abdullah and his brothers, who held a meeting by night in the house of the youngest brother Abu Zaki. This night meeting may have been merely a conference to discuss changed conditions, or it may have been in the nature of a conspiracy. Such meetings continued for some time, and very probably treasonable plans were suggested, even if not seriously adopted: at any rate suspicion was aroused, the brothers were watched, and full information of their proceedings was carried to the Mahdi. One morning Abu 'Abdullah appeared at court with his garment turned inside out, the Mahdi took no notice. Next day the same thing happened, and so on the third. On the last of these occasions the Mahdi asked him why he wore his garment so. He replied that it was an oversight; he had not noticed that it was turned the wrong way. The Mahdi continued, "Did you not pass the night at the house of Abu Zakir?" - - he replied, "Yes,"_-"Why did you do so?"-Abu 'Abdullah answered that he did so because he was afraid. The Mahdi remarked that one only feared when there was cause to believe that there was an enemy. He then showed that he was fully aware of the meetings, that he knew the names of those present, and the subject of their conversation. As a punishment he declared that the three brothers should be expelled from Kairawan, and that Abu Zaki, who seems to have been the moving spirit, should be sent to Tripoli as governor. There had been a revolt of the Hawarite tribe in Tripoli, and so it seemed that $\mathrm{Abu}$ Zakir was to be sent on military service as a punishment, replacing the governor who was his uncle. At Kairawan this seemed a just and proper measure, for conspiracy could hardly be passed over, but the penalty involved no disgrace or apparent severity. So $\mathrm{Abu}$ Zaki set out for Tripoli bearing a letter to the governor. 
But unknown to him the letter contained orders for his instant execution. As soon as the governor read the letter he sent for Abu Zaki and showed it to him; the nephew admitted that it was the will of God and submitted to be beheades. News of this was sent by carrier pigeon to the Mahdi, who perceived that it was now time to get rid of the other two brothers before they took the alarm. He invited them to a repast, but sends two officers, Garwaih al-Mulusi and Ja'bar al-Mili, to conceal themselves behind the castle of as-Sachu and way-lay them as they passed. They did so and killed them with pikes. The bodies laid uncared for at the brink of a cistern until after the following noon, then the Mahdi orders them to be taken up and given a public funeral at which he himself officiated. In explanation of his action the Mahdi wrote a letter to the Shi'ites of Asia in which he said: "Ye know the position in which Abu 'Abdullah and Abu 'Abbas stood with regard to Islam; but Satan hath caused them to stumble, and they have been punished with the sword. Farewell"' (Arib b. Sa'id, Nicholson, p. I28).

But the murder of $\mathrm{Abu}$ 'Abdullah was not taken easily by all the Katama tribe, and a riot followed the funeral. At this the Mahdi showed the personal courage which, equally with a total absence of scruple or gratitude, became characteristic of his dynasty. Mounting his horse he rode out into the streets, and declared that now justice was satisfied, and that no further enquiry would be made or punishments inflicted. He was so far successful that the people dispersed quietly.

IVe may take the murder of Abu 'Abdullah as marking the establishment of the Khalifate at Kairawan. Hitherto it had been more or less surrounded with a religious atmosphere; it had been essentially connected with a particular religious sect. Now, with the death of $\mathrm{Abu}$ 'Abdullah it is established frankly as a secular power, although the religious claims are still maintained in the background. The Shi'ite position, however, now appears rather as political than sectarian. The orthodox Khalif was ruling at Baghdad, but the Mahdi's followers regarded him simply as a usurper. The same view was taken by the Umayyad rulers in Spain, although at this time they had not yet ventured 
to assume the title of Khalif. Amongst the Shi'ites proper the Khalif exists only as the "concealed" Imam, and the visible ruler on earth is merely his viceroy : but the Mahdi claimed to be not only Mahdi, but the heir of the Imams, and thus assumed the Khalifate as the legitimate heir of 'Ali. 


\section{V \\ THE FATIMID KHALIFS OF KAIRAWAN}

LED by religious enthusiasms, the Berber tribes had succeeded in sweeping away the Arab government of the province of Ifrikiya. To a very large extent, however, this was as much a racial and anti-Arab movement of the Berbers as a religious one : of course, very much the same has been true of every Mahdist movement in Africa. The history of Islam is full of similar revolts, for the most part either with a religious motive, or at least a religious pretext. Now the destructive work was finished and the Mahdi settled at Kairawan, having damped or perhaps quenched the religious fervour of his followers by the execution of $\mathrm{Abu}$ "Abdullah and the implied shelving of the miraculous powers which his earlier followers had associated with him, was faced with the task of constructing an orderly and stable principality out of what must be confessed to have been rather unpromising materials. More than once the Semitic and Berber tribes have shewn themselves quite capable of nation-building, and their work has not always been short-lived. The religious motive was effective in arousing the enthusiasm of fighting men, the task of framing political institutions demanded different qualities. At this time, no doubt, we must regard the Mahdi as primarily a political adventurer: that he had any serious regard for Shi'ite principles is incredible; that he was the missionary of an enlightened philosophy which would deliver men from the fetters of religion,- - a position which may have been true of his ancestor 'Abdullah,-is extremely improbable in his case. Unexpected circumstances had given him an exceptional opportunity as the founder of a dynasty, and we have now to see how he used this opportunity. 
Towards religion the Mahdi's attitude had been at first one of rabid Shi'ism, though he, as one of the fully initiated, could not have been sincere : no doubt he was acting up to what he expected to be the feelings of his subjects so far as he had observed the Katama and the immediate followers of Abu 'Abdullah : closer acquaintance with the people of Kairawan showed him that he had been mistaken, the people generally were quite ready for a Mahdi, or any-one else, who could establish and maintain an orderly government, but as Muslims they were orthodox by a large majority, and by no means willing to accept the rather fantastic theories of incarnation and transmigration which appealed to the Persian mind. As soon as this was made clear the Mahdi formulated a definite policy in religion, enforcing strictly all the outward observances of Islam, rigidly punctilious in the prohibition of forbidden food and drink, and punishing severely those of the Isma'ilian sect, who tried to practice the freedom of the higher grades of the initiated. It was no doubt possible for the initiate to disregard the rites of religion in their private life, but any external neglect, likely to cause scandal amongst the populace at large, was treated as a criminal offence: there was none of the open lawlessness of the Qarmatians tolerated in Ifrikiya : the inner grades of the sect were distinguished from other Muslims only by their reverence for the family of 'Ali, whom all revered to some extent, by their repudiation of the first three Khalifs, which was offensive to the orthodox but not intolerable, and by a few minor differences in the ritual of prayer, and in the treatment of the problems of the canon law.

The most difficult problem demanding the new ruler's immediate attention lay in the lands to the west, for the Mahdi claimed to control all the territory to the Atlantic, over which the Aghlabid princes had pretended to rule. The first difficult task came in the revolt of Tiharet.

For long past the Berber lands of North Africa had afforded a refuge for every persecuted sect and dynasty of Islam. The earliest sect, the Kharijites, the wild men of the desert who adhered to the oldest form of purely Arab Islam, had entered Africa after they had been hurited down and slaughtered in Asia by the 
Umayyad Khalifs. In the days of the Mahdi they still held their own in the district of Tiharet in the mountainous country of Central Maghrab. They threw off all allegiance to the ruler at Kairawan and invited Muhammad b. Khazar to be their Emir. The Mahdi sent the Katami Aruba b. Yusuf against them : after three days seige the city was taken, plundered, and some 8,000 of the inhabitants slain.

The Umayyads who had put down the Kharijites in Asia had been compelled by the course of events to seek a refuge in Africa for themselves, and thence had passed over to Spain which was regarded as the remotest of the western parts. At this time they were ruling at Cordova (they did not assume the title of Khalif until A.H. 3I 7), and held also some possessions in Africa about Oran. The same Karmati leader who had taken Tiharet was able to seize Oran.

The Idrisid dynasty, descendants of 'Ali by Hasan, expelled from Madina in 169 , had founded a state in the remoter part of Morocco where they were still ruling. This state also was attacked by Aruba and reduced, so that all the western lands to the Atlantic coast was brought under the control of the Mahdi (Ibn Khald. i. 244-5, 267-8, etc.).

This course of consolidation of the most loosely held part of the Muslim world speaks well for the organising ability of the general Aruba, and established the Mahdi's authority upon a sound foundation. It was, however, disturbed by domestic difficulties in the capital. Kairawan was an Arab colony, but under the Mahdi the Berbers were in the ascendant, and racial disputes were inevitble. One day a Katama tribesman treated a city merchant with insolence; a riot ensued, and some 1 , ooo of the Katama were slain. After this had been repressed the governor rode through the city and ordered the dead bodies of the Berbers to be removed. The workmen who carried out this order threw the bodies into the channel which served as the city sewer. At this the Katama tribesmen removed from the city in indignation, and declared that they would no longer submit to the Mahdi's rule, and chose a vouth named Kadu as their emir. Very soon this rebel was in possession of the whole province of $\mathrm{Zab}$, and the Mahdi sent several generals against him 
without result. Some of these generals, indeed, deserted to the enemy, for the Berbers were the main fighting force in Africa, and there was a general indignation amongst them at the way in which the Katama rebels in Kairawan had been treated, and there were many followers of Abu 'Abdullah still who threw in their lot with the revolted Berbers. At length 'Ubayd Allah sent his son Abu 1-Qasim, and he, with some difficulty, managed to reduce the tribesmen.

In 300 the colony of Tripoli revolted. There, as in Kairawan, there had been riots between the Berbers and Arabs. When Abu 1-Qasim returned from punishing the tribes he advanced to attack Tripoli, whilst the Mahdi at the same time sent a fleet against it, and after some delay it was reduced. Then Sicily revolted, and this proved to be a permanent loss to the Fatimid Khalifs. At first the Sicilians invited Ahmad, a son of Ziadat Allah, the former emir of Kairawan, to take charge. He refused, but after some time, as the invitation was repeated, he consented to be recognised as emir of Sicily. As soon as he was established he sent a letter to the Khalif of Baghdad professing loyalty and asking to be confirmed as emir by the Khalif. Thus Sicily broke away from the Fatimid dominions and became once more a part of the empire of the 'Abbasid Khalif.

In 301 the Mahdi founded a new city on the coast near Kairawan, and gave to it the name of al-Mahadiva. The site was very badly chosen, and the place afterwards decayed completely, although it served as the Fatimid capital for some generations. At the same time he commenced building a fleet, by the help of which he hoped to make an attack upon Egypt in due course; no doubt he was by this time convinced that his kingdom in North Africa was not likely to be a stable one, just as it had been held precariously by the Arab rulers who preceded him: in fact it was an unsettled and savage country, which could be under control only so long as under actual military occupation. Probably, also, he hoped that the prospect of conquering Egypt would attach the Berbers to him more successfully. The weak point in these plans was that the building and manning of a fleet depended almost entirely on what Greek help he could hire. Soon 
afterwards he sent his general Khubasa eastwards and extended his authority, somewhat precariously, to Barqa. In the summer of 302 he made his first attempt against Egypt, sending forces by land under his son Abu 1-Qasim, and Khubasa against Alexandria. The inhabitants of that city were obliged to take refuge in the ships in the harbour, whilst the invaders plundered their houses. The invading army then passed southwards to the Fayyum, but here they were met by an Egyptian army strongly reinforced from Baghdad, and compelled to retire. The effort, however, had brought the invasion of Egypt within the sphere of practical politics, and the plunder of Alexandria raised much enthusiasm amongst the Mahdi's followers. At that time the 'Abbasid Khalifate was in its decline: in Baghdad the government was in the hands of the military guard, the commander of that guard was the real ruler, the Khalif being no more than a figure head liable to be deposed and replaced at the will of the soldiery. The provinces were semi-independent, in most cases ruled by hereditary emirs who paid no more than a formal tribute of respect to the Khalif; indeed, in many cases it meant simply that his name was mentioned in the Friday prayer. Of all the provinces Egypt was, perhaps, the worst administered, and the ripest for falling away from the 'Abbasid dominions. It was on the verge of disintegration by natural decay, whilst the Fatimid state which coveted it, though outwardly strong and efficient, had already showed that it had the seeds of internal weakness in the tribal jealousies of Berbers and Arabs.

In 307 the Mahdi's armies made another attempt on Egypt, this time supported by a fleet of 85 ships, which passed along the coast from al-Mahadiva and anchored in the harbour of Alexandria. The Khalif's officers at Baghdad could only get together 25 ships which were assembled at Tarsus and sailed over to Alexandria. But those twenty-five ships were manned by experienced Greek mariners, and inflicted a decisive defeat on the Mahdi's fleet.

As Egypt now enters very directly into the affairs of the Fatimids, it will be necessary to consider its condition. For the last four years it had been governed by the Emir Dhuka ar-Rumi, i.e., Ducas the Roman 
(or Greek). Before the defeat of the Mahdi's fleet Dhuka resolved to check the invaders who had followed their former route to the Fayyum, and were laying waste and plundering at will. He had great difficulty in inducing the Egyptian army to move at all, but at last marched out to Giza and encamped on the same side of the Nile as the Mahdi's army. Soon afterwards he died, and the governorship was taken over by Tekin al-Khassa, who had been governor before from 298 to 303 and had been associated with the former victory over the Shi'ites. Immensely popular with the soldiery, his resumption of office made an immediate change, and he was able to take the offensive and inflict a serious check upon the invaders, about the same time as the naval victory at Alexandria. Although the Fayyum was cleared the Fatimid forces were still in control in Upper Egypt, whither their cavalry had pressed on whilst others stayed in the Fayyum. There the extreme narrowness of the Nile valley and the exposed condition of the Bahariya and the other oases always meant a minimum of defence, and the invaders were able to hold their own until the next year. That meant that the whole area was infested by bands of light cavalry, rapidly moving Bedwin, both Berber and Arab, always able to retreat at will into the neighbouring desert and very difficult to be restrained by any ordinary military force. In our own dealings with the Sanusi in 1916 we had experience of such difficulty. The only possible solution is a system of organised military patrol, which takes some little time to dispose efficiently. That Egypt was cleared after a few months' interval shows that Tekin had considerable ability in handling the military task with which he was confronted.

These attacks of the Shi'ites revealed another weakness in Egypt. There was strong reason to suspect that they had many sympathisers there. There was an active branch of the Isma'ilian propaganda at work in the country, and all who were initiated in the sect were of necessity spies and helpers of the invaders. Two at least of the leading officials, the Qadi and the Treasurer were in correspondence with the Mahdi and in his employ: this does not mean that they were converts to the Shi'ite sect, but simply that they were disloyal to 
their own service as the result of personal jealousies and rivalries, the perennial bane of all oriental governments. It was only the support of the army which maintained Tekin, and even so he was not in a position to attack his rivals in the government. When he had been successful in clearing the country of the Mahdi's forces, he had his reward in dismissal from the governorship in which he was succeeded by Muhammad b. Hamal, but three days later he was restored, to be deposed again soon afterwards as the result of more palace intrigues. The two following governors, Hilal b. Badr and Ahmad b. Kayghalagh, held office, the first for two years, the other for one, and then in 312 Takin was restored and remained governor until his death in $32 \mathrm{I}$. Conditions indeed were such that only a military leader with the support of the army could exercise any effective control in the country. The reinforcements sent from Baghdad in 302 had done more harm than the Shi'ite invaders; they had totally demoralised the native soldiery, and the army was now no more than a large troop of brigands who lived on the plunder of the country. At his appointment in $3 \mathrm{I}_{2}$ Takin established the army in camps around his own palace as well as in quarters in the building itself, and, more by the force of his own personality than anything else, managed to keep them fairly in hand until his death. It was no small feat, for he was utterly unable to provide them with their pay, which was many years in arrear. At his death the governorship was assumed by his son Muhammad, but he had not his father's power or popularity, and was soon mobbed and driven out by the discontented soldiers clamouring for their pay. The Treasurer Madara'i, who was in the Mahdi's employ and largely responsible for the disorder in the finances, was obliged to hide himself. Several ambitious officers assumed the title of Governor and tried the expedient of raising funds by brigandage organised on a larger scale than usual, and the country had relief only in the fact that these were soon occupied in war against one another. It is not difficult to understand that the eves of many Egyptians were turned longingly towards Kairawan, where the Mahdi, in an efficient though somewhat brutal manner, was administering a firm and well ordered state, maintaining civil law and 
peace. This is the easier to appreciate when we remember that Isma'ilian missionaries were busy in Egypt, and the orderly government at Kairawan would naturally form one of their arguments.

At this juncture, when Egypt was plunged in anarchy, the Khalif at Baghdad intervened and appointed as governor Muhammad b. Tughj the Ikhshid, son of the Emir of Syria, who had himself been governor of Damascus since 318. As his name denotes, this new governor was of Turkish birth. For some time now the Khalifs, seriously alarmed at the growing independence of the various dynasties of hereditary governors, especially in Persia and the neighbouring lands, had been introducing Turkish mercenaries, reckless of the inevitable consequences.

The conditions of the Khalifate at this time show a close parallel with those prevailing in Europe under the later Karlings, when "the governor,-count, abbot, or bishop-tightened his grasp, turned a delegated into an independent, a personal into a territorial authority, and hardly owned a distant and feeble suzerain", (Bryce: Holy Rom. Empire, p. 79). So each governor appointed by the Khalif became the founder of an independent dynasty, barely conceding the mention of the suzerain's name in the khutba and on the coinage. Such were the Tahirids who ruled in Khurasan from 205 to 259, the Saffarids in Persia from 254 to 290, the Samanids in Transoxiana and Persia from 288 to about 40o, the Hamdanids who established themselves at Mosul in 292, at Aleppo in 333, and ruled there until 394, and the Aghlabids whom we have seen in Kairawan.

The Ikhshids claimed to be descended from the ancient kings of Ferghana on the Jaxartes, a district inhabited by fighting races, from whom the Khalif alMu'tasim (2r8-227) drew many mercenaries. The first of the Ikhshids to serve the Khalifs was a mercenary named Juff, and he continued in the Khalif's employ until his death in 247. One of his sons named Tughj was in the service of Lu'lu, who acted as squire to Ibn Tulun in Egypt, and, when his master died, in that of Ishaq b. Kundaj, and afterwards in that of Ibn Tulun's son, Abu 1-Jaysh Khumasawaih, who regarded him with great favour and formed a very high opinion of 
his military abilities, in consequence of which he procured for him the governorship of Damascus and Tiberias. At his patron's death Tughj offered himself to the Khalif al-Muktafi, who considered this an act of marked loyalty, and was greatly pleased with him, and made him one of his confidential officers. These favours provoked the jealousy of the wazir al-'Abbas, and he succeeded in getting Tughj cast into prison where he died. He left two sons, Muhammad and 'Abdullah, who burned to avenge their father's death, and their resentment was gratified when they saw al-'Abbas executed by the Hamdanid al-Husayn.

After this the elder son, Muhammad, went to Syria and joined himself to Takin, who was governor of Syria as well as of Egypt. In this service he prospered and was made governor of Amman. Then in 316 he was appointed to Ramla, in $3 \mathrm{I} 8$ he was transferred to Damascus, which led the way to his appointment as Emir of Egypt. This last charge was given him in $32 \mathrm{I}$, but the state of Syria did not allow his immediate departure, and Egypt was left for a while in the hands of Ahmad b. Kayghalagh, who returned to office temporarily. By 324 Syria had been reduced to order, and Muhammad the Ikhshid went over to Egypt to assume his governorship in person, leaving his brother 'Abdullah in Syria.

There were some in Egypt who did not like the prospect of this new governor, and amongst these was the Treasurer Madara'i, who induced the acting governor, Ibn Kayghalagh, to take up arms to resist his entry. The Egyptian army marched to the frontier and engaged the Syrians and Turks under the Ikhshid at Farama, the ancient Pelusiun, now more generally known as Tineh (Arabic $t \hat{\imath} n=$ Greek $\pi \eta \lambda$ ós " mud"), near the Egyptian end of the " short desert route," via al-Arish from Syria. The result was a complete defeat of the Egyptians, and so Muhammad the Ikhshid continued on his way to the capital Fustat " Old Cairo"') without further opposition. Meanwhile the Syrian fleet had sailed up the Nile and anchored off Giza, thus commanding the city until the Ikhshid marched up his forces and took possession. The arrival of the new governor and his army, largely Turkish in composition, established a firm and efficient 
government in Egypt again until his death in 335. At their first arrival indeed the Turkish troops began plundering the city, but they were soon called to order and then, although the new governor was severe and exacted heavy contributions, this stern rule was welcomed as it recalled the peace and prosperity of the golden days of Ibn Tulun. The resultant peace very soon opened up the way to literary activity and scholarship, and Egypt began to follow, though at a distance, the culture of 'Iraq. This literary development, as well as theological discussion and debates on jurisprudence, centered in the " Old Mosque," which was also the scene of the most important state functions.

Although the establishment of the Ikhshid rule in Egypt gives the appearance of supreme power to the Khalif at Baghdad, who seems thus able to dispose of provinces and appoint governors at discretion, his position at the time was really very precarious. The Buwayhid dynasty of governors had established itself in 'Iraq in 320 (=A.D. 932), but Baghdad itself remained under the Khalif until 334, though generally he was only a tool in the hands of the commander of the garrison. These Buwayhids claimed descent from Buwayh, a prince in the hill country of Daylam, and so ultimately from the ancient kings of Persia. They appeared as rivals of other Daylamites led by Bajukin, who was Emir al-Umara or "Supreme Prince," and had control of the government under the Khalifs arRazi and al-Muttaqi. Alarmed at the progress of the Buwayhids, Bajukin took up arms against them in 327 , but was compelled to abandon his efforts by the report of disorders in Baghdad. Soon afterwards Bajukin was killed by a band of Kurdish marauders, and the capital was left in a state of anarchy. Then Baridi became Chief Emir, but was expelled a few weeks later: then the Daylamite Kurtakin, who turned out to be a tyrant. At this the Khalif appealed to Ibn Raiq, the Emir of Syria, and he expelled Kurtakin. Not long afterwards Baridi attacked Baghdad and Ibn Raiq had to flee, taking the Khalif with him to Mosul, which was in the hands of the Hamdanids. As champions of the Khalifate the Hamdanids marched against Baghdad, took it, and ruled there for a short time, until the Turk Tuzun drove them out and made himself Emir 
al-Umara in 331. Then another revolt drove him out, and the Khalif appealed again to the Hamdanids and escaped to Mosul; but when peace was concluded between Tuzun and the Hamdanids the Khalif remained in their hands. At this time, indeed, the Khalifate was very far from showing the character of an absolute monarchy. All over the Muslim world the Sunni, or orthodox party, recognised the Khalif as the Commander of the Faithful, except of course in Spain where the Umayyads of Cordova assumed the title of Khalif in 317 . Enjoying great dignity and prestige in an office which combined many of the characteristics of the Pope and Emperor in the $11^{r}$ est, he was in fact no more than a puppet, a valuable asset in the hands of any one of the warring dynasties of Asia, but possessing no real authority. Yet his formal recognition was eagerly sought as a precious endorsement of de facto rights by Muslim rulers, and even princes in faroff India humbly begged his approval of their titles. It seems indeed as though the office of Khalif gained in spiritual influence as it lost in political authority.

Whilst in exile and in Hamdanid's hands, the Khalif appealed to the Ikhshid whom he had set over Egypt, and Muhammad visited him at Riqqa and invited him to take refuge in Egypt; but al-Muttaqi, though anxious for help to recover the external symbols of authority at Baghdad, was not willing to put himself so entirely in the Ikhshid's hands; he knew that Ikhshid and Hamdanid alike only desired to possess his person as a kind of imperial regalia, and so he preferred to entrust himself to the Turk Tuzun, who at least could establish him in the capital. He reigned in Baghdad in name only until 333, when Tuzun deposed him, put out his eyes, and enthroned al-Mustakfi in his place. But this was followed by a period of anarchy in Baghdad, until in 334 the Buwayhid prince took the city. A few months later al-Mustakfi was deposed and replaced by al-Mu'ti, whose position under the Buwayhid princes was parallel to that of the Frankish kings under the "Mayors of the Palace," with the aggravated condition that the Khalifs were spiritual pontiffs and the Buwayhids were, like the Hamdanids, Shi'ite heretics of the "Twelvers" sect. Buwayhid's rule over Baghdad lasted from' 384 to 447 , 
when the Emir was displaced by the Saljuk Turks under Tughril Beg. Throughout this period the Buwayhids were content with the title of Emir alUmara; they never assumed that of Sultan.

It has been necessary for us to turn asidel to note the position of the Khalifate at the time, for otherwise we should have some difficulty in understanding the course of events in Egypt, which now takes the foremost place in the policy of the African Shi'ites. It is often possible to ignore the contemporary history of Spain and of North Africa when following the course of events in Egypt, but Egypt forms so integral a part of the world of Islam that it is never possible to treat its history, even during the comparative isolation of the Fatimid period, without some passing note of the contemporary history of the Baghdad Khalifate.

Whilst these changes were taking place in Asia and the Ikhshid was consolidating his power in Egypt, the Mahdi continued ruling at Kairawan, and, though North Africa was one of the most turbulent and the least civilized parts of the Islamic world, his rule was stable and orderly. In 312 he added a suburb to the city which he called al-Muhammadiya, and which served as a kind of royal cantonments closed against the ordinary citizens, and used only as an official settlement of those engaged in the public administration and as the site of the various public offices. Such official suburbs were very frequent in oriental capitals, and become a regular feature of the great Muslim royal cities. The Mahdi's later years were somewhat clouded by his relations with the Qarmatians, who were still active in Asia, and who caused the whole Isma'ilian movement to be regarded with grave suspicion by the Muslim world at large.

Since $3 I I$, as we have seen, the Qarmatians had occupied Basra. In 317 they had spread down into the Hijaz, and on the 8th of the month of the pilgrimage in that year the pilgrims who had come up to Mecca were attacked by them. The Sherif of Mecca, many of his attendants, and many of the pilgrims, were killed: the sacred spring of Zamzam was choked up with the bodies of the slain which were tumbled in: the door of the "House of God" was broken open, the veil which covered the House was torn down, and the 
sacred black stone was removed from the Ka'aba and carried away to the Qarmatian headquarters at Hajar. Never in the history of Islam has there been sacrilege at all comparable to this, and never before had the Qarmatians advertised so boldly their contempt for the Muslim religion. Begkem, the Emir of Baghdad, offered them a reward of 50,000 dinars to restore the sacred stone, but the offer was refused.

According to Ibn Athir, quoted by Ibn Khallikan (i. 427 , etc.) the Mahdi, then wrote to them from Kairawan: "By what you have done you have justified the charge of infidelity brought against our sect, and the title of 'impious' given to the missionaries acting for our dynasty; if you restore not what you have taken from the people of Mecca, the pilgrims and others, if you replace not the Black Stone and the veil of the Ka'aba, we shall renounce you in this world and the next." This letter was more effectual than Begkem's proffered reward, and the Qarmatians restored the Black Stone with the statement, " We took it by order, and by order we return it." It was restored either in Dhu 1-Kaada or Dhu 1-Hijja of 339. Of the year there seems no question, and Ibn Khallikan points out that the Mahdi died in 322. He suggests, therefore, that the letter and the Qarmatian reply were fabrications, presumably for the purpose of throwing the odium of sacrilege on the Mahdi. But it is not necessary to suppose that the Black Stone was returned immediately in response to the Mahdi's request. A more likely interpretation is given by Macdonald, who accepts the letter as genuine and comments: "When an enormous ransom was offered for the stone they (i.e., the Qarmatians) declined-they had orders not to send it back. Everyone understood that the orders were from Africa. So 'Ubayd Allah found it advisable to address them in a public letter, exhorting them to be better Muslims. The writing and reading of this letter must have been accompanied by mirth, at any rate no attention was paid to it by the Qarmatians. It was not till the time of the third Fatimid Khalifa that they were permitted to do business with that stone" (Macdonald: Muslim Theology, pp. 46-4i). This suggests a plausible explanation, that the letter was sent by the Mahdi, but was only intended to disclaim any responsibility for the 
taking of the stone on his part; that it was not intended to be heeded, and was not taken seriously, the stone being detained until long after the Mahdi's death. This theory would fit in with the policy of the Fatimids at Kairawan, which carefully avoided anything likely to offend the orthodox, and would dispose of Ibn Khallikan's objection, which is based on the supposition that the date of the return of the stone was shortly after the writing of the latter. The letter assumes that the Qarmatians and the Fatimids were members of the same sect. Undoubtedly they had been so originally, but later on they definitely separated, and we are not clear as to the time of this division. It seems probable that the external quasi-orthodoxy of the Fatimids in Africa was the cause of its separation from the Qarmatians, who had made more open profession of the destructive elements of their religion.

The Mahdi died in 322 (A.D. 933), and was succeeded by his son Abu 1-Kasim, who assumed the name of aì-Qa'im. 


\section{VI}

\section{THE SECOND FATIMID KHALIF, AL-QA'IM (A.H. $322-335=$ A.D. $933-946)$}

THE new Khalif, al-Qa'im, had already shown himself an efficient leader in the two expeditions against Egypt, and in the vigour with which he repressed the simmering revolts in Africa. His accession was marked by two expeditions; a naval attack on the south of France, the coast of Genoa and Calabria, which resulted in the bringing home of many slaves and plunder: and another attempt on Egypt, which, however, was promptly checked by the Ikhshid's brother, 'Ubayd Allah.

At the moment Egypt was too well administered to allow opportunity for invasion such as had taken place in $307-8$. The Ikhshid was doing his best to held Syria and to bolster up the tottering throne of the Khalifs, but had forces to spare for the protection of Egypt. It is true that he was defeated shortly afterwards by Ibn Raiq, who had seized Damascus and was compelled to pay tribute, but after two years' payment Ibn Raiq died (A.H. 326), and then the Ikhshid was able, not only to recover all that he had temporarily been compelled to yield, but was in a position to extend his dominions, and brought Syria under his control. Not long afterwards the Khalif entrusted him with the guardianship of Mecca and Madina. At that time the Ikhshid was the only loyal supporter on whom the Khalif could rely, chiefly, of course, because of his jealousy towards those who threatened the throne of Baghdad.

Unable to divert his subjects by the long hoped for conquest of Egypt, al-Qa'im had to meet more serious rebellions in the west than his father had experienced. The principal revolt took place amongst the Zenata tribe of Aures and Zab, south of the Katama territory, 


\section{FATIMID KHALIF, AL-QA'IM}

nearly all members of the Kharijite sect, led by a darwish named Abu Yazid, who assumed the title of " Sheikh of the true believers," but was better known as " the man with an ass." This movement was mainly of a nationalist character, and aimed at establishing a purely Berber state in which Arabs should have no place. The Berbers had won Spain, and had done most to place the Fatimids on the throne of Kairawan, but in both cases they seemed to have been cheated out of the fruits of their labours by wily Asiatics, and so the motive in this revolt was the assertion of their racial rights.

In 332 Abu Yazid marched northwards at the head of most of the Zenata tribe of the south, hereditary rivals of the Katama, and many other Berbers. In rapid succession he took Baghai, Tabassa, Mermajenna, and Laribus. The Fatimid forces tried to prevent his advance upon Baja, but were repulsed. It was the story of $\mathrm{Abu}$ 'Abdullah over again, but this time it was a Berber at the head of Berber tribes, and the religious motive assigned was the restoration of the primitive ideals of Islam, the democratic election of the Khalif, and all the reactionary programme of the Kharijites which was, and is, the most congenial to the nomadic tribes of Africa and Arabia. We have seen very much the same programme in the history of the Sanusi in recent times. The successful repulse of the Fatimid army made a great impression, and all the Zanata tribes of Zab, the Hwaras of the Aures, and many others, rallied round Abu Sazid. At the head of a large, but undisciplined force, he marched towards Kairawan : on the way he met a Fatimid army, but this time suffered defeat. It was, however, no more than a temporary check; he soon rallied, took Raqada, and then pressed on to Kairawan, defeated the forces of the Fatimid Khalif, and captured the city. Al-Qa'im was obliged to take refuge in al-Mahadiya, which $\mathrm{Abu}$ Yazid forthwith beseiged. At this juncture the Katama and Sanhaja tribes came in mass to relieve the city, and Abu Yazid's followers, demoralised by the steady resistance of the defenders, were obliged to retire. As they retreated al-Qa'im followed, and was soon able to recover the whole of Tunisia, but after an interval Abu Yaizd rallied and laid seige to the town of Susa. 
At this juncture al-Qa'im died, and was succeeded by his son, who took the name al-Mansur (the protected).

Al-Qa'im' had accompanied his father, the Mahdi, in his flight from Syria, and had proved himself a trusty and competent general before his accession to the throne. He figures in history solely as a fighting man : we hear nothing of any development either in the Isma'ilian sect or in the organization of the Fatamid state. 


\section{VII}

\section{THE THIRD FATIMID KHALIF, AL-MANSUR}

(A.H. $335-34^{2}=$ A.D. $946-953$ )

THE stability of the Fatimid Khalifate was problematical when al-Qa'im died at the height of Abu Yazid's rebellion. The first task of the new Khalif al-Mansur was to relieve Susa, and he was fortunate enough to inflict a severe defeat on Abu Yazid, and to drive him back to the mountains of Kiana in the extreme west of Ifrikiya. There a stubborn struggle followed which lasted a whole year, but was terminated by the final defeat and complete rout of the insurgent Berbers, Abu Yazid himself being mortally wounded in the final engagement and dying soon after.

This revolt, however, begins the decay of Fatimid authority in the west. The Zanata tribes of Maghrawa and $\mathrm{B}$. If rene were able to form a separate state in the neighbourhood of Tlemsen, whilst the Umayyads of Spain established a colony at Fez, where they placed the descendants of Musa ibn Abi 1-Afia and his followers. Syrian Arabs who had been invited to Spain but had become obnoxious, and whom it was advisable to segregate from the earlier settlers in Spain. Central Maghrab, roughly corresponding to the greater part of Algeria, was held by the Sanhaja tribe, steady allies and supporters of the Fatimid Khalifate, under the government of Ziri b. Menad, who built the town of Achir as his capital.

Such was the position when al-Mansur died in 342 and was succeeded by his son Ma'ad, who took the name of al-Mo'izz. Al-Mansur's reign had been occupied entirely in dealing with Abu Yazid's rebellion, and in the consolidation of the country after this rebellion had been put down. It cannot be said that he left the Fatimid state in a strengthened position 
when compared with conditions under the Mahdi, for already independent states had begun to be formed in the West, but he had dealt successfully with the emergency existing at the time of his accession.

The Fatimid state was essentially an hereditary one, for the Shi'ite theory implied the legitimate descent of the Imam. The recognition of Isma'il, the son of Ja'far, clearly showed that the father's claimed right of disposing of the succession was invalid in the eyes of the sect of Seveners. From that time the succession had been strictly hereditary. But the Fatimids, seated in power, borrowed the constitutional usage of the Khalifs of Baghdad, and secured the succession by obtaining formal recognition of the heir during their lifetime. Thus Ma'ad was formally recognised as next in succession on Monday, the 7 th of Dhu 1-Hijja 34I, and came to the throne in the following year. In the 'Abbasid Khalifate this recognition was a relic of the earlier election, and meant that the next Khalif was formally elected by the princes during his predecessor's lifetime, the orthodox Khalifate not being professedly hereditary. The case was otherwise with the Fatimids who were legitimist, and could only have as Imam the one chosen by God, and to whom alone the Divine Spirit could pass at the preceding Imam's death. No doubt the formal recognition during the father's lifewas adopted as a measure of precaution; theoretically it might be defended by the supposition that its point was the father's public recognition of his son and heir, but the real case seems to be that it was simply borrowed from the usages of the court of Baghdad, and marks a relaxation of the theocratic and sectarian character of the Fatimid state which is gradually inclining towards becoming a purely secular one, differing from the Baghdad Khalifate in little more than in that it professed Shi'ism as the established religion. 


\section{VIII}

\section{THE FOURTH FATIMID KHALIF, AL-MO`IZZ (A.H. $342-365=$ A.D. 953-975)}

THE new Fatimid Khalif was of a type somewhat different from his predecessors. Like them, indeed, he proved an able and efficient ruler, but unlike them he was a man of cultured tastes and of considerable literary ability. His heart was set on the conquest of Egypt, the great dream ever present before his father and grandfather, which seemed now coming within the bounds of possibility.

To understand this we must turn for a while to the course of events in Egypt. The Ikhshid Muhammad b. Tughj had died in 335 , and had been succeeded by his son Abu 1-Qasim Unjur, a child of I5 $^{5}$, who was kept in a state of pupilage by a black eunuch named Abu 1-Misk Kafur, i.e., "Camphor, the father of musk." This Kafur was an ungainly black slave, of ponderous bulk and mis-shapen legs, who had been púrchased as a boy of ten in the year 310 and sent one day with a present to the Ikhshid; the present was returned, but the messenger was retained. Little by little he rose in the service, first of the Ikhshid's household, then in that of the state, conciliating everyone by his pleasing manners and fair words, and was finally appointed by the Ikhshid atatek, or guardian, to his two sons. At the Ikhshid's death a riot broke out, and this Kafur put down with such tact that he was regarded with even greater favour and consideration by all the public officials. Soon afterwards news arrived that the Hamdanid Sayf ad-Dawla 'Ali had taken Damascus, and was marching upon Ramla. At once Kafur set out at the head of the army and checked 'Ali, returning home with considerable booty. This greatly increased his reputation, and, although holding no constitutional 
authority he was able to get all the business of the state into his hands, and was generally conceded the title of ustad or " tutor," a word often used in the same sense as patron in French, and under this title he was mentioned in the khutba or Friday prayer. As his ward Unjur grew older, however, a more or less veiled hostility arose between them, each on his guard against the other, until the titular prince died in 349 , not without suspicion of being poisoned by the ustad, although such suspicions were usual in every case where a death seemed to be timely : the oriental world has always had an obsession for poisoning.

Kafur was now strong enough to control the appointment of the next heir and, as Maqrizi expresses it, appointed the deceased prince's brother Abu 1-Hasan 'Ali to succeed him, paying him an annual pension of 400 , ooo dinars, and reserving the whole administration in his own hands. The new Emir, though 23 years of age, was kept shut up and was permitted to see no-one. However, the same strained feelings arose between him and the ustad as in the case of his brother, and when he died in 355 there were the same suspicions. For some time Egypt remained without a regular governor, - -it must be remembered that the Emir was theoretically no more than a viceroy appointed by the Khalif at Baghdad,-and all the power continued in Kafur's hands as he declined to proclaim Anujin's son, saying that he was too young to occupy the position of Emir. About a month after Abu 1-Hasan 'Ali's death he displayed a pelisse of honour sent from Baghdad and a charter nominating himself governor under the title of ustad, and on Tuesday, the loth of Safar 355 (Feb., 966), he began to wear the pelisse in public (Ibn Khall. ii. 524, etc.).

Before long the Khalif al-Mo'izz made another attempt upon Egypt, and his army advanced to the oases before the western frontier, but Kafur checked the advance and slew several of the invaders, but received at his court some of the Fatimid missionaries whom al-Mo'izz sent as envoys to invite Kafur to recognise his authority. The Ustad received them favourably, and most of his entourage and the chief officials gave their promises of homage to the Fatimid. It seems, indeed, that Kafur had formed the definite 
plan of transferring allegiance from the 'Abbasid Khalif to the Fatimid, or rather that such a transference should take place at the next vacancy in the governorship of Egypt.

Kafur never repeated the military enterprise or success of his two earlier expeditions, his defeat of the Hamdanid and his repulse of the Fatimid, if indeed this latter can be regarded as a success. He was unable to prevent the Qarmatians who had raided Syria in 352, from capturing the caravan of Egyptian pilgrims on their way to Mecca in 355 . Nor could he restrain a Nubian invasion into Egypt which plundered the more southern districts and took home much booty. Still more serious misfortunes which were not under his control were the two low Niles, producing famine and misery, and a severe fire which destroyed parts of Fustat, as well as an earthquake. On the whole the four years of Kafur's rule were a period of distress and discontent.

Yet many in after days looked back to those years as a kind of golden age. It was a period in which the later growth of Arabic literature was in full tide, that later literature which contrasted with the ancient Arabic poetry of the more strictly classical period, when both prose and poetry were manipulated mainly by men who were not Arabs by race, but obtained a greater technical skill than the earlier writers had achieved. To that later literature the negro ruler of Egypt showed himself a generous patron and his court was filled with poets, wits, and men of letters who were attracted to Egypt by the liberality of the black Maecenas. Like most of his race he was passionately fond of music; and the beautiful gardens which he laid out on the north of Fustat, gardens which the Fatimids incorporated in their royal city of Cairo, transmitted his name to succeeding generations. He was lavish in his expenditure, - the negro is always ostentatious, - and especially so on the daily provisions of his kitchen, but this was counted in his favour, for the Arabic tradition was that princes should dispense an open handed hospitality, and the Egyptians of ancient and modern times have had a strong inclination to appreciate feasting and the indulgence of the appetite. But most welcome of all to his table were poets and epigrammists, who rarely 
went away without some substantial rewards for their literary efforts. One poet was able to leave behind him a hundred suits of robes of honour, twice that number of vests, and five hundred turbans. Such literary courtiers naturally turned their genius to complimentary verses about their patron. One, playing upon his name Kafur or " camphro," composed verses on the fragrant scented gardens which he had laid out, and which long stood for the ideal gardens in the Egyptian mind: another explained in verse how the shocks of earthquake had been caused by the Egyptians dancing for delight as they contemplated Kafur's merits, an effusion which caused the delighted Ustad to throw him a purse containing a thousand dinars. Amonst his pensioners was the poet al-Mutanabbi, who had left the court of the Hamdanid Sayf ad-Dawla in anger at the smallness of his presents, and thought little of a prince who did not come up to his very high standard of generosity. At first Kafur used to smile graciously at him, but the poet wanted presents and not mere compliments. " When I went into Kafur's presence," he said, "with the intention of reciting verses to him, he alwavs laughed at seeing me and smiled in my face, but when I repeated to him these lines:-

' Since friendship has become a mere deception, I am repaid for my smiles with smiles; but when I choose a friend my mind misgives me, for I know he is but a man':

he never did so again as long as I remained with him. I was astonished at this proof of his sagacity and intelligence." He was very quickly dissatisfied with Kafur. " IThat I want," he said, "I declare not; thou art gifted with sagacity, and my silence is a sufficient explanation, nay a plain request." At length he left Kafur's court, dissatisfied at the liberal gifts he received because they were not ample enough, and revenged himself by writing satires on Kafur, such as :-

"Who could teach noble sentiments to this castrated negro?-his white masters?-or his ancestors who were hunted like wild beasts?"

The poet finally settled at the court of Adud ad-Dawla at Shiraz (Ibn Khall. ii. 524, sqq.).

But Kafur, though easy going and with many of the weaknesses of the negro, was a man who had the wit to 
acquire more than a superficial education by the right use of opportunities which were often available to the ambitious slave, and which indeed form one of the redeeming features of slavery as it existed in Muslim lands. Besides this he was a painstaking and efficient administrator, and a man of deep religious convictions.

In all Kafur ruled the country twenty-two years, part of the time as tutor to the two sons of the Ikhshih, part as independent viceroy in all but name. During the closing years of this period he became unpopular. Feeling had been strained by the famine due to the bad Niles, and the reports of the Qarmatians' advance into Syria bred disaffection amongst the Turkish and Greek mercenaries. On Tuesday, the 2oth Jumada I. 356 (May, 967), he died at the age of sixty, leaving property to the value of 700,000 dinars of gold, and goods, furniture, jewels, slaves, and animals valued at some 600,000 dinars.

Kafur's death left Egypt in a state of confusion. The court assembled to elect a governor; a significant mark of the times, for no reference was made to the Khalif at Baghdad, who was a mere phantom. The choice fell on Abu 1-Fawaris Ahmad, grandson of the Ikhshih Muhammad b. Tughj, who was a mere child. Soon after this, however, there arrived in Egypt Husayn, the son of 'Abdullah, the brother whom Muhammad had left in Syria in 32r. During the thirty years which had elapsed since then Ubayd and his son had had a chequered military career, and the son now arrived as a fugitive, fleeing from the Qarmatians. His arrival was welcome to the Turkish troops who forthwith elected him their general, and he at once assumed the supreme power. The use he made of this authority was to arrest the wazir Ibn al-Furat and torture him until he wrung from him a large sum of money with which he departed at once to Syria. During his brief stay in Egypt he had been guilty of other acts of cruelty and rapacity, and when a year later he was himself sent a prisoner to Egypt, there was a general feeling of satisfaction that he was himself treated with severity. His departure for Syria took place on the first of Rabic II. $35^{8}$ (Feb., 969). The rule of the Ikhshids, or at least their nominal authority, continued for five months 
more until the summer of the same year (Ibn Khall. Life of Tughj).

It was a time of acute disorder. Famine had followed the failure of the Nile, and plague had followed the famine. The soldiers had their pay diminished, their customary gratuities were in arrear, and they were in open mutiny, for there was no controlling hand to restrain them. The administration was in the hands of the wazir Ibn al-Furat, who had been plundered by 'Abdullah, and he was unable either to pay the troops or to relieve the distress of the people. It was clear that under these conditions the country would be in no condition to offer effective resistance to an invader, and this was the moment chosen by the Fatimid Khalif to make his attack.

For two years (356-357) al-Mo'izz had been making detailed preparations for the invasion of Egypt. In $35^{6}$ he had commenced constructing roads, digging wells along the roadside, and building rest-houses at regular intervals. At the same time he began collecting funds for the necessary expenses and paying substantial sums to the Katama leaders, who were thus enabled to arm and equip their followers. As we have already seen, there had been Fatimite missionaries for some time at work in Egypt, and al-Mo'izz had even made formal advances to Kafur and had been well received, and his proposals for coming to Egypt had been heard with politeness: he certainly had many strong adherents in high office in Egypt. Now the general disorder following the famine and plague, and the disorganization after Kafur's death seemed to furnish the right opportunity, just as all his preparations were mature.

An even more important task had been performed in bringing all North Africa into complete subordination. Cultured literary man as the Fatimid Khalif was, he was also a most efficient organizer, and was well served by officials whom he treated with generous confidence. The disciplining of Africa was a necessary preliminary to an expedition outside the bounds of the country, which might well be of protracted duration and uncertain issue. For this he had the assistance of an able general, Abu 1-Hasan Jawhar b. "Abdullah, commonly known as " Jawhar the Greek scribe," as he was a liberated slave trained as a secretary, whose father had 
been subject of the Byzantine Empire. Like Kafur he shows that the slave in Islam was not merely treated as a fellow man, but had a career of ambition open before him, in which his servile origin was no obstacle; even in modern times slaves have risen to high office, and have sometimes married princesses. There was no colour barrier nor any racial feeling : no reluctance was felt at white men being ruled by a negro ex-slave.

Marching to the Maghrab, Jawhar joined forces with the Sanhaja chieftain Ziri, who was one of the most faithful allies of the Fatimids (cf. p. 123), and together they advanced upon the Umayyad colonies at Fez and Sijilmasa. These they took and thus prevented the possibility of Spanish interference in Africa for the time. Continuing westwards they reduced the whole Maghrab to the coast. As a sign of the extent of the expedition fish were caught in the ocean, and sent in jars to the Khalif in company with the princes of $\mathrm{Fez}$ and Sijilmasa, who were conveyed in an iron cage. The only town left to the Umayyads was Sibta (Ceuta). The Idrisid princes of the far west, descendants of Hasan, the son of 'Ali, were put down, and thus their independent rule which had lasted just over two centuries came to an end. It was a more thorough reduction of the country than had ever been made previously, and when Jawhar returned to Kairawan al-Mo"izz was recognised as the unquestioned ruler of all North Africa.

The Khalif determined to entrust the invasion of Egypt to Jawhar, who had so clearly proved his efficiency in the reduction of the Maghrab, but just about this time Jawhar fell ill. Al-Mo'izz was not willing to replace him, and continued his preparations, assembling troops and supplies at Raqada: every dav he visited the general who, as soon as his health was sufficiently restored, the order to advance was given.

Jawhar was the commander of the Fatimid force, but with him was another who played an important part in the subsequent construction of the Fatimid state in Egypt. Yaqub b. Killis was a native of Baghdad, by origin and for many years by religion a Jew. His father sent him first to Syria, then to Egypt, where he became a chamberlain to Kafur, then received a seat on the privy council and acted as accountant and 
treasurer. He became a Muslim in 356. At Kafur's death he was arrested by his rival the wazir Ibn alFurat, but by bribing his gaolers he managed to escape and fled to Kairawan. The expedition against Egypt was already in full preparation, but he joined himself with Jawhar and proved a useful adviser. He was commonly regarded as the instigator of the enterprise, but this does not seem to be accurate.

Jawhar's start was made on the I $4^{\text {th }}$ of Rabi' II. $35^{8}$ (A.D. 969). Al-Mo'izz attended with his court to bid him farewell. During this meeting the general stood before the Khalif, who leaned down on his horse's neck and spoke to him privately for some time. The Khalif then ordered his sons to dismount and give Jawhar the salutation of departure; this obliged all the great officers of state to dismount also. Jawhar then kissed the hand of the Khalif and the hoof of his horse and, mounting at his master's command, gave the word for the whole force to march. When al-Mo'izz returned to his palace he sent as a present to Jawhar all the clothes he had been wearing at the farewell interview, save only his drawers and signet ring. At the same time he sent forward orders to Aflah, the governor of Barqa, that he should set out to meet Jawhar and kiss his hand. Aflah offered a gift of Ioo,ooo dinars to be permitted to escape this act of homage, but was obliged to submit (Ibn Khall. i. 341-2).

Jawhar first advanced upon Alexandria. The city capitulated on liberal terms; there was no pillage and no violence to any of the inhabitants, as Jawhar was able to restrain his well-paid army in admirable discipline.

The news of Jawhar's approach caused great dismay in Fustat. It was decided that the wazir Ibn al-Furat should write to him and ask for peace with security for the lives and property of the citizens. At the same time Abu Ja'far Muslim b. 'Ubayd Allah, an emir of high standing, and an acknowledged descendant of Husayn the son of 'Ali, was asked to go in person to plead with Jawhar, it being assumed that an 'Alid envoy would carry weight with the Shi'ites. Abu Ja'far consented on condition that a company of citizens went with him (id.).

The deputation set out on Monday, the I8th of Rajab 
358 (=18 June, 969) and met Jawhar at Taruja, a village not far from Alexandria. They delivered their appeal to him, and he immediately granted all their requests, and confirmed his promised by a written statement. With this the envoys returned to Fustat, where they arrived on the 7 th of Shaban. The wazir Ibn al-Furat rode out to meet them, read Jawhar's statement, and handed to each of his companions who had written to Jawhar asking for appointments under the new government his replies, which were in all cases favourable. Some time was spent then in discussion, but the informal gathering dispersed without agreeing to any uniform attitude towards the invaders. The city was still in great alarm, and the adherents of the Ikhshids, the officers who had served under Kafur and some of the army, determined to reject Jawhar's prooffered peace and to make armed resistance. Valuables were concealed, a camp was formed, and Nahrir ashShoizai was chosen general. Under his leadership the Egyptian army marched out to Giza and set companies to guard the bridges.

On the IIth of Shaban, Jawhar arrived, having been informed of the intended resistance. He took several prisoners and marched to Muniat as-Sayadin (the village of the fishermen) and seized the ford of Muniat Shalkan. At this some of the Egyptian troops passed over in boats and surrendered, but the men on the Fustat side put a guard at the ford. Then Jawhar stripped to his trousers, and at the head of his men waded into the river, and thus arrived at the other side where they attacked the defenders and killed a considerable number. Night had now approached, and under the cover of darkness the rest of the defenders fled from the city, carrying off from their houses whatever they could. A deputation of wives waited on Abu Ja'far asking him to write to Jawhar and obtain, if possible, a renewal of his previous offers of peace. Abu Ja'far wrote as requested : the Fatimid general readily assented, and issued an order to the troops forbidding pillage and violence. At this the city recovered its confidence, the bazars were re-opened, and commercial life went on its normal course (Ibn Khall. i. 343).

On Tuesday, the 17 th Shaban, by Jawhar's order, a deputation of leading officials, sharifs, the learned, and 
prominent citizens went out to Giza. By orders announced by a herald everyone except the wazir Ibn al-Furat and the Sharif Abu Ja'far, dismounted and saluted Jawhar in turn, the Fatimite general standing with the Sharif on his right hand, the Nazir on his left. After this ceremony was concluded the envoys returned to the city, and the troops commenced their entry with arms and baggage. After the "Asr or hour of mid-afternoon prayer Jawhar himself made his entry preceded by drums and flags; he wore a silk dress heavily embroidered with gold, and rode a cream coloured horse. He rode straight through the city with his men, and passing out on the north-east side pitched camp there.

Late in the evening in the camping ground he marked out a great square of $\mathrm{I}, 200$ yards base, and men were stationed, spade in hand, ready to start the foundations of this new city, or rather royal suburb, when the signal ivas given. The projected lines, all sketched out by al-Mo'izz himself beforehand, were marked with pegs, and bells were hung from connected ropes so that a signal might be given for the simultaneous turning of the first sod. Meanwhile the astrologers were busy calculating the propitious moment for the birth of the city. Unexpectedly, however, a raven settling down on one of the ropes set all the bells jingling, and the men at once thrust their spades into the soil. It was too late to check them, though the astrologers found that it was a most inauspicious moment as the planet al-Kahir (Mars) was in the ascendant. There was nothing for it but to accept the omen, and the city thus commenced was named al-Kahira (Cairo), or more fully al-Kahira al-Mahrusa (the guarded city of Mars). It was designed as a royal suburb to be entirely devoted to palaces and official buildings, inacressible to the general public, similar to the city of al-Mahammadiya outside Kairawan. In course of time, however, the main part of the population of Fustat migrated to Kahira, and it is now the most populous city in the whole of Africa.

Fustat, or Misr al-Atika, or simply Misr, was the old Arab city founded in A.H. 2 I soon after the conquest. In 133 the suburb of al-'Askar to the north-east was 
added, but this was simply cantonments for the government officials, and was not accessible to the ordinary citizens. Al-Qatai" " the wards," a kind of additional cantonments intended for the foreign mercenary troops, was added in 256 , but was partially destroyed by the later 'Abbasid governors and finally abandoned. AlKahira stood further to the north-east, and it was after the burning of Fustat in 564 that the population generally began to colonize this suburb.

When the people came out from the city next morning to Jawhar's camp they found, to their unbounded surprise, that the foundations of the new city had been dug during the night. For six days after the troops continued entering the old city, passing through, and going out to the new suburb where was Jawhar's camp. News of the successful occupation of Egypt was without delay sent to the Khalif, and with it were the heads of the Egyptians slain at the ford.

Jawhar now issued orders that all mention of the 'Abbasid Khalif at Baghdad in the Friday prayer must cease, and in place of his name the coinage must bear the inscription bi-smi mula'i l-Mo'iss, " in the name of my master al-Mo'izz." At the same time the preachers in the mosques were forbidden to wear the black garments usual under the 'Abbasids, and were ordered to use white, a similar order being issued to public officials generally. It was ordered that every Sunday a court should be held for the "Inspection of complaints," for the hearing of petitions against officials and against the administration, the Ka'id or military governor, i.e., Jawhar himself, being present as well as the Wazir, Qadi, and a number of men learned in the law, so that those who had complaints against officials which lay outside the scope of the ordinary law courts might obtain redress. The court did not try cases, but on hearing a complaint referred it to the proper qadi with orders to see that it received attention. The decision was then sent to the court of "Inspection of complaints," and written out in substance by a secretary, and then passed on to another secretary who put the summary in full legal form. This was taken to the Khalif who confirmed it, and this authoritative decision was then communicated to the petitioner, who had the 
whole protection of the state behind him in putting it into effect.

On Friday, the 8th of Dhu 1-Kaada, in the khutba, the words were added, " O my God, bless Muhammad the chosen, 'Ali the accepted, Fatima the pure, and al-Hasan and al-Husayn, the grandsons of the Apostle, whom thou hast freed from stain and thoroughly purified. O my God, bless the pure Imams, ancestors of the Commanders of the faithful "' (Ibn Khall. i. 344). This was at once a profession of Shi'ite faith, and an assertion of the claim of al-Mo'izz to be descended from the house of 'Ali. There is no sign that any appreciable number of the Egyptian-sbecame converts to Shi'ite views: for the most part these claims were regarded with complete apathy until the celebration of the great Shi'ite festival of the Muharram, when there was some rioting. The people at large acquiesced in the new rule without paying any attention to its religious claims.

On Friday, the r8th of Rabi' II. 359, the Ka'id Jawhar himself presided at the public prayers and sermon in the Old Mosque, that is the Mosque of 'Amr. The building then existing had been erected by 'Abdullah b. Tahir in $2 \mathrm{I} 2$, and is still standing. It escaped destruction when the city was burned, but suffered a disastrous restoration in A.D. I 798. At this service many soldiers were present. The preacher was 'Abdu s-Sami b. U'mar al-'Abbasi, who in the khutba made especial mention of the " people of the house," i.e., the family of 'Ali, and prayed for the Ka'id, although Jawhar did not approve of his own name being thus mentioned, saying that no authority for it had been given in the instructions he had received from alMo'izz. In the call to prayer the Shi'ite custom of adding the words " come to the excellent work" was adopted. In the month of Jumada I. this addition was made in the call to prayer at the Old Mosque, at which Jawhar was greatly pleased, and made a report of the circumstance to the Khalif (Ibn Khall. i. 344-5).

Meanwhile progress was being made with the building of al-Kahira. The new city was surrounded with a wall of large bricks, of which the last fragments were observed by Maqrizi in A.D. 1400. In the middle of the great enclosure was an open space, the Bayn al- 
Kasrayn, " between the two palaces," as it was afterwards called, large enough for Io, ooo troops to be paraded : a small portion of this open space remains as the Suq an-Nahhasin. On the east was the Khalif's palace; one corner of its site is now marked by the Khan al-Khalili, another by the Husanayn Mosque. The name of the square was of later date, and due to the fact that al-Mo'izz's successor built a lesser palace on its west side, at the beginning of the beautiful garden which Kafur had laid out, and which the Fatimid Khalifs maintained. A great thoroughfare led through the midst of Kahira from the Bab al-Zuwayla on the south side, communicating with the old city of Fustat, and passing through the Bayn al-Kasrayn to the Bab al-Futah, which led out to the open country on the north. To the north of the Khalif's palace lay the Wazir's official residence, and to the south the mosque of al-Azhar, which Jawhar commenced soon after the foundation of Kahira and finished on the 7 th of Ramadan, 36r. Although the existing building has been much modernised it retains enough of the older structure to show the typical character of Fatimid architecture. The horse shoe arch, commonly regarded as of Persian origin, seems to have been developed in Egypt, and appears first in the Nilometer and then in the mosque of Ibn Tulun : it had an Indian parentage, and was not introduced into Persia until it had already been employed in Egypt (Rivoira : Moslem Architecture, E.T. I 54, etc.), at least no dated example is found until later than the mosque of al-Azhar. The Fatimid style shows this horse-shoe arch combined with high imposts which occur in the mosque of Ziadat Allah in Kairawan (A.H. 816-837); " nor does it seem an unnatural conjecture that it was Jauhar, not only a distinguished general, but also a man of letters, and therefore of culture, who suggested the form to some Christian architect of Egypt: and that, under these circumstances, the designer of the building, wishing to endow it with some distinctive feature marking the accession of the new dynasty, modified the pointed arch of Tulun's time under the influence of the Indian 'cyma reversa' or ogee arch" (Rivoira : op. cit. I 57).

In general plan, style, the use of brick piers, etc.. the mosque of al-Azhar followed the model of the 
mosque of Ibn Tulun, and so was a development of Egyptian native taste. The minaret was of heavy square type with outside stairs which has always remained popular in western Islam.

The most novel feature introduced by the Fatimid architects was the pendentive, the pensile cusped framing arch over a recessed angle. This appears clearly in the interior of the dome of the mihrab in the mosque of al-Hakim, commenced in 380 but not completed until 404. But this reproduces the pendentive as it appears in the mosque of Cordova (A.H. 350-366) in the bay in the front of the mihrab, and had its precursor more than four centuries before in the church of St. Vitale at Ravenna.

It is impossible, therefore, to connect Fatimid architecture with Persia: obviously it was developed out of the older Egyptian Muslim style under the influence of western and European, i.e., Italo-Greek, models. As usual, art is a clear indication of the general line of culture contact and intellectual influences. Though Asiatic and Persian in origin the Fatimids were, by their heretical character, entirely cut off from the Islamic world in Asia, a severance which the Fatimid rule in Syria, being one of purely military occupation, did not bridge over. Isolated in art, it was isolated in philosophy and literature, although this isolation from the Muslim world at large was richly compensated by its close contact with Shi'ite circles, and by some contact with the Greek and Roman Empire along the shores of the Mediterranean.

The wall surrounding the whole city of Kahira was finished in 359. To its south-east lay the old city which remained the centre of commercial and non-official life until the end of the Fatimid dynasty, and to the west the suburbs of Maqs, which extended down to the river and remained the port of Cairo until the shifting of the Nile in the $13-14$ th cent. A.D. gave the opportunity for the building of Bulaq.

The first serious problem with which Jawhar had to deal was the famine due to the successive bad Niles. Fortunately al-Mo'izz had sent a number of ships laden with grain as soon as he heard that Jawhar had occupied the country, and this caused some temporary relief in the city, and showed the people that they had 
a ruler anxious to assist them. At the same time Jawhar established a public corn exchange under an inspector (muhtasib), who had to prevent hoarding and excessive prices, and several offending millers were flogged. Of course these primitive expedients produced no serious relief, although they evoked the sympathy of the people, and a state of famine continued until the end of 360 , and there were still cases of plague. In the following winter, i.e., in the early months of $36 \mathrm{r}$ (October, etc., of A.D. $97 \mathrm{I}$ ), the famine came to an end, and in the course of the next few months the country began to recover, and as a consequence the plague disappeared

In the year $36 \mathrm{I}$ an Ikhshid officer in the district of Bashmur revolted, but was put down, chased to Palestine, captured there, and put to death. So far there had been very little reluctance to the change of government, in this insignificant revolt as in the first efforts to oppose Jawhar it is only a few of the Ikhshid officials who seem to feel the slightest grievance.

Jawhar now felt anxious to raise the prestige of Egypt, which had suffered greatly since the death of the first Ikhshid governor. In 355 the Nubians had invaded the country, so now in 362 he sent an embassy to king George of Nubia, inviting him to become a Muslim and to pay tribute. The Nubians, it must be noted, remained Christians down to the I 4 th cent. A.D. The embassy was politely received, tribute was paid, but no further reference was made to religious differences.

Jawhar found that as ruler of Egypt he was necessarily involved in the politics of Syria, some portions of which had been, at least nominally, part of the Ikhshid dominions. Indeed, Egypt never has been free from Syrian connections, either in ancient, mediaeval, or modern history. At this time independent Shi'ite princes were ruling at Aleppo, and Husayn the Ikhshid. who had returned to Syria after plundering the Wazir Ibn al-Furat, held his own at Ramla. Against him Jawhar sent his lieutenant Ja'far b. Fellah, who attacked and defeated him. Husayn was brought a prisoner to Fustat, publicly exposed as a proof of the power of the Fatimids, and viewed with great satisfaction by the inhabitants of the Egyptian city who remembered his cruelties. He was then sent on to a 
prison in Ifrikiya, where he died in 371. After defeating Husayn, Ja'far marched north and occupied Damascus. But this brought the Fatimids into conflict with the Qarmatians, for Damascus had for some time past been paying tribute to the Qarmatian leader Hasan b. Ahmad, and this payment was now stopped. After the death of Abu Sa'id, the kabir of the Qarmatians, in 30I, as we have already noted, the leadership was held temporarily by Abu 1-Kasim Sa'id, and then passed to Abu Tahir Sulayman who attacked Mecca. Abu Tahir died in 332, as well as a third son of Abu Sa'id named Abu Mansur Ahmad. Then the eldest brother, Abu 1-Kasim, resumed the leadership. In 360, the date we have now reached, the chieftain was Hasan b. Ahmad (Abu 1-Feda, Ann. Moslem. ii. 325, 350, 509). It seems that at this time there had been a complete rupture between the Shi'ites of Africa and the Asiatic Qarmatians, though we are quite in the dark as to when or why this took place. It may have arisen from this attack upon the tribute paying city of Damascus, which the Qarmatians regarded as aggressive : or it may have had an earlier origin, perhaps in the relaxation of Isma'ilian doctrine and practice amongst the African Shi'ites when they accommodated themselves to the tone generally current at Kairawan. Now Hasan had no hesitation in proposing an alliance with the orthodox Khalif of Baghdad against the Fatimids, but this was rejected by the Khalif with contempt. The Shi'ite Buwayhid prince who was the real ruler of 'Irac, however, was more complaisant, and a third ally was found in the Hamdanid prince of Rabha on the Euphrates, whilst various Arab tribes, always ready to join in any fighting and usually as much an embarrassment to their allies as to their enemies, readily agreed to take part. Thus helped Hasan captured Damascus and celebrated his achievement by the public cursing of al-Mo'izz in the great Mosque. Theoretically, the Oarmatians professed to believe in the divine right of the Fatimid Imam, and so this cursing seems strange. It may be that the people of Damascus, who were fanatically anti-Shi'ite, were responsible, or it may be that the Qarmatian's no longer troubled to pretend an attachment to the reputed house of 'Ali, but displayed their total indifference to 
all religious considerations without reserve. After taking Damascus Hasan marched south rapidly and, avoiding Jaffa where Ja'far and his army were stationed, passed through Ramla and made a lightning descent on Egypt itself. He surprised Kulzum (Suez) and Farama (al-Arish), and thus commanded the whole Isthmus of Suez, whilst Tinnis declared in his favour. He then advanced into the country and encamped at 'Ayn Shams (Heliopolis), and threatened Cairo. Jawhar had commenced defensive measures as soon as he heard that Hasan had reached the Isthmus and had made a trench before the city. The real danger lay in the possible treachery of officials of the old régime, and a spy was told off to watch Ibn al-Furat. At the same time men were sent to Hasan's army who, under the pretence of being discontented citizens, made treacherous overtures to its officers. After some delay Hasan attempted to storm the trench, but was driven back with heavy losses, the most surprising incident being the unexpected courage shewn by the Egyptian volunteers who were enrolled in Jawhar's army. A number of Ikhshid officers who were serving with Hasan were taken prisoner, and Hasan was compelled to retire to Kulzum, leaving his baggage to be plundered by the Egyptians.

News of the attack on Egypt had been sent to alMo'izz, and soon after the defeat reinforcements arrived from Kairawan under Ibn 'Ammar. Thus supported Jawhar advanced on Tinnis, which was now penitent for its defection and was pardoned. A Qarmatian fleet which had sailed up the Nile to support Hasan fled hurriedly, and was obliged to abandon seven vessels and some 500 prisoners.

Jawhar had effectively repelled the Qarmatian invasion, and acted prudently in following up the retreating enemy and relieving Jaffa. Hasan fell back upon Damascus, but after some delay there began to recover and commenced preparations for a new attempt.

At this juncture Jawhar felt that the time had arrived when al-Mo'izz ought to be commanding in Egyptian in person, and wrote earnestly entreating him to come and take up the reins of government, and this appeal decided the Khalif to remove from Kairawan to Cairo. Early in 363 al-Mo'izz appointed Bolukkin b. Ziri 
of the Sanhaja tribe as deputy in If rikiya, advising him " never cease levying contributions on the nomadic Arabs, and keeping the sword on the (necks of the) Berbers; never appoint any of your own brothers or cousins to a place of authority, for they imagine that they have a better right than you to the power with which you are invested; and treat with favour the dwellers in towns" (Ibn Khall. i. 267).

Having thus provided for the government of Ifrikiya al-Mo'izz then set out. Passing by Qabus, Tripoli, Ajdabiya, and Barqa, he reached Alexandria in the course of the spring, and there received the Qadi of Fustat and other officials. At the beginning of the summer he encamped in the gardens of the monastery at Giza, and there received Jawhar who came out to welcome him on his arrival. After resting a short time he made his solemn entry into the capital. Although Fustat was decorated ready for his coming, he paid it no visit, but marched straight to his palace in Kahira where he took up his abode. In this solemn entry the coffins of the three Khalifs who had been his predecessors were carried in the first ranks, escorted by two state elephants, and the Khalif himself rode surrounded by his four sons and other kinsmen. He entered the roval city by the " gate of the arch," one of the two openings in the Bab az-Zuwayla. The other opening which no longer existed in Maqrizi's time was generally regarded as unlucky. This bab is now commonly regarded as the mysterious dwelling place of the head of all the darwishes who, wherever he may be, is supposed to be able to fly in spirit to this abode, and there the spirit is placated. The legends connected with this gate seem to have varied from age to age, but it has always been regarded as haunted by mysterious presences.

Soon after taking up his abode in the royal palace, on the great feast day which terminates the fast of Ramadan, al-Mo'izz conducted prayers in the newly finished mosque of al-Azhar which, it will be remembered, lay within the guarded precincts, and so was not accessible to the public. The mosque, commenced by Jawhar in 360 , had been completed in 361 . In 378 the following Khalif, al-'Aziz, devoted it especially to 
the learned, and from this it has gradually become the leading university of Islam.

But al-Mo'izz was not able to remain as a sacred character in the seclusion of the guarded city, although that perhaps was his first intention. The Qarmatians were still threatening. Al-Mo'izz wrote to Hasan proposing negotiations, but the Qarmati chief merely replied, "I have received thy letter, full of words, but empty of sense : I will bring my answer."

In the following spring the Qarmatians appeared again at 'Ayn Shams, and helped by Ikhshid partisans, spread far and wide through Egypt. Al-Mo'izz sent his son 'Abdullah with some 4,0oo men into Lower Egypt and he gained several minor advantages over some of the marauding bands of Qarmatians, but this did not prevent the main body from assembling before Jawhar's trench which they prepared to assault. By means of spies the Khalif managed to bribe the Arab tribe of B. Tayy, the strongest factor in Hasan's army, allies but not themselves of the Qarmatian sect, to desert, the price being 100,000 dinars. As the treasury did not contain sufficient gold these coins were specially struck of lead and gilt. In the next attack the B. Tayy rode away and Hasan was routed, his camp plundered, and some 1,500 of his irregular followers slain. The advantage was pressed home by the Egyptians who advanced into Syria, but after this defeat the Qarmatians began to fall to pieces as the result of internal disputes.

The defeat of the Qarmatians was followed by the appearance of a new danger in the person of the Turkish leader Haftakin. This man had been a slave in the service of the Buwayhid prince, Mo'izz ad-Dawla, and rose to a leading position in command of the Turkish mercenaries under his son Azz ad-Dawla Bakhtiar (Maq. ii. 9). In the course of a battle which took place outside Baghdad between the Turks and the Daylamites, Haftakin, though himself acting with exemplary courage, was deserted by most of his men and compelled to flee with a small body of some 400 followers. At first he took refuge at Rabha on the Euphrates, but afterwards moved to Syria. The Syrian Arabs were alarmed at his approach, and appealed for help to Ibn Ja'far, the Fatimite governor of Damascus, 
who was easily convinced that Haftakin was acting on behalf' of the 'Abbasid Khalif of Baghdad, and so took the field against him. But the Emir of Aleppo sent a force under the eunuch Bashara to the help of Haftakin, and as soon as this became known the Arabs deserted Ja'far and went home. Bashara then escorted Haftakin to Aleppo (Abu 1-Feda) or Emessa (Maqrizi), where the Emir received him well and bestowed on him many presents.

At Damascus Ja'far was faced with a discontented group of citizens, and they even formed themselves into armed bands under the leadership of one Ibn Maward. As soon as these men heard of Haftakin's arrival in Syria, they opened negotiations with him and invited him to Damascus, promising to join him in expelling the Fatimid garrison and to recognise him as emir. Damascus, it must be remembered, was fanatical in its hatred of the Shi'ites. Haftakin agreed to these proposals, and towards the end of Shaban 364 proceeded as far as Thaniyyat al-Okab on the road to Damascus.

At this juncture Ibn Ja'far heard that the Greeks were intending to make an attack upon Tripoli in Syria, and so marched his forces out of Damascus to intercept them. This gave Haftakin his opportunity, and he was able to enter Damascus without opposition. After a brief stay there he went down to Ba'albak to chastise the Arabs who had taken up arms to assist Ja'far against him, but was surprised by a large Greek force, which was pillaging Ba'albak and laying waste the surrounding country: he was only just able to escape before them and seek safety in Damascus whither the Greeks soon followed him. The citizens sent out an embassy to ask for terms, and were informed that the city would be spared in return for a substantial fine. Soon Haftakin went out to the Greels camp and explained that he was unable to raise the promised fine because of the obstacles put in his way by Ibn Maward and his partisans, the free militia of Damascus. As a result of this the Greek Emperor, John Tzimisces, sent officers into the city, who arrested Ibn Maward and brought him out a prisoner. By this means the city was cleared of its irregular forces and Haftakin took full possession, raising the sum of 30,000 pieces of gold 
as a fine with great rigour. He paid the sum to the Greeks, who forthwith retired to Beirut and thence to Tripoli.

Thus Haftakin became absolute master of Damascus, and formally recognised the suzerainty of the 'Abbasid Khalif of Baghdad. He was afraid, however, that the Fatimid Khalif would before long take steps to recover his hold over Syria, and so wrote to the Qarmatians at Lahsa, their headquarters in the Bahrayn, asking them to ally themselves with him against al-Mo'izz. They accepted these proposals and a large body of them arrived before Damascus in 365 , where they encamped for a few days; after resting and conferring with Haftakin they passed on to Ramla, where the Fatimid general Ibn Ja'far was in command, and at their approach he retired to Jaffa, and they occupied Ramla. Meanwhile Haftakin, as agreed with the Qarmatians, marched along the coast, and at Sa'ida (Sidon) engaged two subordinate Fatimite generals, Dhalim b. Marhub and Ibn ash-Sheikh, whom he defeated. Dhalim then withdrew to Tyre, and Haftakin had the hands of the slain of the Fatimite army cut off and sent as a trophy to Damascus (Maq. ii. 9).

Just about this time the Khalif al-Mo'izz died, his son 'Abdullah having pre-deceased him. He had spent only two years in Egypt but, besides the decisive repulse of the Qarmatians, he had established a government, which on the whole was a fair one and kept good order in the land. To avoid racial disputes, such as had disturbed Kairawan, he settled his African troops at al-Khandaq near 'Ayn Shams and, although they were allowed to visit Fustat freely during the day, all were required to leave the city before nightfall. In dealing with the inhabitants of Egypt both al-Mo'izz and Jawhar put aside all prejudices, whether of race or religion, and took a simply practical attitude, at heart no doubt regarding all religions as equally worthless. The Copts were as a rule far more efficient as clerks, accountants, and scribes, than their Muslim fellow countrymen, and they, as well as some Greek Christians, were largely employed in all the subordinate branches of the administration, and even to rise to some of the higher offices. As a practical measure this was 
thoroughly satisfactory, but the fact that the tax collectors and practically all the finance officials were Christians or Jews, caused the gradual evolution of a strong feeling of dislike against members of these two religions. Undoubtedly also the methods of oriental finance gave opportunity for much oppression and dishonesty, and the Copts and Jews were unable to avoid these temptations, so that much of the prejudice felt against them was justified. Although the employment of Christians and Jews in the civil service is more or less an established tradition in Muslim lands, it was carried much further by the Fatimids than had been usually the case.

Al-Mo'izz entrusted the task of organising a new system of taxation to the converted Jew, Ibn Killis, who had had experience of administrative work under Kafur, and to 'Asluj. The old system of farming out the taxes was abolished and the whole was centralised, whilst at the same time a new assessment of land and taxable sources was made. All arrears wese rigorously called up, but very careful consideration was given to every appeal and complaint. The whole system of taxation was strictly enforced, but efforts were made to protect the tax-paying community from unjust exactions. As a result the revenue of the state was considerably increased, the daily takings in the city of Fustat alone ranging between 50,000 and 120,000 dinars. At the same time, however, al-Mo'izz commenced an extravagant expenditure on the erection of the royal suburb of Kahira, and this was followed by ostentatious and luxurious outlay on an unprecedented scale, so that the actual financial position of the government was not much improved on the whole. A taste for display became a characteristic of the Fatimid dynasty, and this tended to exert a demoralising influence on the community generally by raising the general standard of expenditure. 


\section{IX}

\section{THE FIFTH FATIMID KHALIF, AL-'AZIZ (A.H. $365-386=$ A.D. $975-996)$}

AL-Mo'izz was succeeded by his son Nizar, who took the name al-Imam Nizar Abu Mansur al-'Aziz bi-llah, and so is generally known as al-'Aziz. Although his father's death took place in the early part of 365 , it was concealed for some time until it seemed that the succession was secure, and the formal proclamation was deferred until the Feast of Sacrifice on Thursday, the $4^{\text {th }}$ of Rabi' II. 365. The traditional picture of al'Aziz represents him as humane, generous, a fearless hunter, and a successful general. Like his father he had a strong taste for building, and erected a great mosque in Kahira, generally known as the Mosque of al-Hakim, as it was finished by his son Hakim, near the Bab al-Futuh : besides this he built the "Palace of gold" facing his father's palace across the great square in the midst of Kahira, also a mosque in the cemetery of al-Karafa, and a palace at 'Ayn Shams (Ibn Khall. iii. 525). These can hardly be called public buildings in the true sense as they were all connected with the royal court, and as such were within the precincts of the "guarded city" and inaccessible to the public generally. In person al-'Aziz was tall, broad shouldered, with reddish hair, and eyes large and of a dark blue colour: in Arab opinion there is something sinister in such hair and eyes. He was not only fond of sport, but had also a marked taste for literature, and was particularly adept at composing epigrams. According to Ibn Khillikan who, as a partisan of the 'Abbasids, delights in reporting anecdotes to the detriment of the Fatimid Khalifs, he once addressed a derisive and sarcastic letter to al-Hakim, the Umayyad of Spain, who replied, "You satirize us because you 
have heard of us; had we ever heard of you we should reply "' (Ibn Khall. iii. 525).

The Fatimid Khalifs were not able to maintain their somewhat dubious pedigree above the reach of criticism. In Egypt there were many undoubted descendants of 'Ali, and some of these, as well as other people, were strongly inclined to resent the Khalifs' pretensions. No serious credence can be given to the story that al-Mo'izz was examined on this subject at his first entry into Egypt, and simply displayed his sword as his title to the throne (cf. 49, above), but no doubt many criticisms were passed in private. One day, when al-'Aziz ascended the pulpit in the Old Mosque he found before him a paper on which was written: "We have heard a doubtful genealogy pro" claimed from the pulpit of the mosque: if what you " say be true, name your ancestors to the fifth degree. " If you wish to prove your assertion, give us your "genealogy, one that is as certain as that of at-Ta'i. "If not, leave your pedigree in the shade and enter " with us in the great family which includes all man" kind. The most ambitious vainly strive to have a "genealogy like that of the sons of Hashim" (Ibn Khall. iii. 525). The "sons of Hashim " means the 'Abbasids, of whom at-Ta'i was then the reigning Khalif. The incident seems probable enough as the Egyptians generally were not at all in sympathy with Shi'ite claims; it seems, however, that there was a growing feeling even amongst Fatimid supporters that the Khalif would do well to discard the Shi'ite religious theories which were now of no assistance to the dynasty, and that he would do better if he posed frankly as a secular ruler. Probably this feeling had commenced to form soon after the execution of Abu 'Abdullah in the time of the first Fatimid: we shall see it gathering force under the son of al-'Aziz, and finally deciding the Fatimids to cast aside all the quasi religious and mystical pretensions which had been adopted at the formation of the sect by 'Abdullah, the son of Maymun.

Like his father, al-'Aziz was favourably disposed towards the Copts and other Christians, but in his case a pro Christian attitude was emplasized by the fact that he had a Christian wife whose two brothers were, by the Khalif's influence, appointed Malkite patriarchs, 
-that is to say, patriarchs of the church in communion with the orthodox Greek Church as distinguished from the Jacobite body to which the Copts belonged,- the one at Alexandria, the other in Jerusalem. The Khalif's favour was extended to the Coptic Church as well as to the Malkite body to which his wife belonged, and permission was given to the Coptic patriarch Efraim to rebuild the ruinous church of Abu s-Seyfeyn in Fustat. A1-'Aziz exceeded his predecessors in the ostentatious display of wealth, introducing new fashions of Persian origin, such as turbans of cloth of gold, gold inlain armour, and other splendours which were copied by the courtiers and nobles. At one time he spent a sum nearly equivalent to $£$ i2, ooo on a magnificent silk curtain from Persia.

Al-Mo'izz had left his successor a difficult problem in Syria. From the first Syria was the hardest burden which the Fatimids had to assume by their entry into the heritage of Egypt, and it is worth remembering that, of the three pieces of advice which Ibn Killis gave to the Khalif as the great wazir was on his death bed, the two first were, try to keep peace with the Greeks, and " be content if the Hamdanids of Aleppo mention your name in the Friday prayer and put it on their coinage."' The ambition to control Syria has always been the fatal temptation of the sovereigns of Egypt, in the days of the ancient Pharaohs as at every period of subsequent history, and the great minister was undoubtedly wise in advising the Khalif not to seek more than a formal recognition of suzerainty. At this moment, however, it was no matter of choice. The Qarmatians had threatened the gates of Cairo, and were now in alliance with Haftakin, who had ejected the Fatimid governor from Damascus : it seemed that the prestige, and perhaps the existence of the Fatimids, depended on their dealing with Haftakin.

Al-'Aziz entrusted the problem of Syria to the general Jawhar who was put at the head of a large army. The news of his approach found the Qarmatians at Ramla, and Haftakin encamped before Acca. The Qarmatians fell into panic when they heard of Jawhar's coming, fled from Ramla and allowed him to take possession of the town. Some of the Oarmatians retired to their own territory of al-'Ahsa in the Bahrayn, whilst 
others dispersed in all directions. Haftakin heard of this and saw himself deprived of his allies, and so retired to Tiberias where he rallied round him some of the scattered Qarmatians and then, helped by his own Turkish levies, prepared to give battle to Jawhar. First he raised supplies from the Hauran and from Bathniyya, one of the districts near Damascus and then, having provisioned the city for a seige, determined to wait the Egyptian general there. Towards the end of the month of Dhu l-Kaada Jawhar arrived and pitched camp before Damascus, surrounding his camp with a deep trench and making regular openings for his men to pass in and out. Haftakin entrusted one Qassam Sharrab a leader of the local irregular force which had evidently been revived in the city, with the task of arranging sorties and attacks on Jawhar's camp, and these went on until the IIth of Rabi' II. of 366 , when the local captain became disheartened as these sorties did not produce any favourable results, and Haftakin himself was beginning to consider the expediency of attempting to escape from the city. Before abandoning Damascus, however, he made every effort to obtain assistance, and at last was cheered by the news that the Qarmatian Hasan b. Ahmad was marching to his relief. When Jawhar heard this he thought it prudent to propose terms to Haftakin, the more so because his own supplies were running short and, to Haftakin's great delight, proposed to retire if he would refrain from pursuit. As this offer was at once assented to, Jawhar withdrew on the 3 rd of Jumada I: and went to Tiberias. As soon as the Qarmatians heard of this they followed to Tiberias, but found that Jawhar had passed on to Ramla. They pursued as fast as they could, and a small engagement took place. The Qarmatian leader Hasan b. Ahmad died at Ramla, and the office of kabir passed to his cousin Ja'far, the army being under the command of Yusuf, the last survivor of the six sons of Abu Sa'id (Abu 1-Feda: Ann. Moslem, ii. 535). After this it became the custom for the Qarmatians to put their forces under the control of six sa'ids, who formed a kind of elective military council. Very soon after Hasan's death they quarrelled with Haftakin and deserted him. Although the retire- 
ment of the Qarmatians left Haftakin in a less favourable position he decided to give battle to Jawhar, with the result that he defeated him, and Jawhar was obliged to flee to Ascalon, leaving a vast booty in the victor's hands (Maqrizi, ii. 9-IO).

Elated by this success Haftakin advanced to besiege Ascalon, but the Khalif al-'Aziz had heard of the late reverse and prepared to march to his general's relief. The preparations in Egypt seem to have been delayed for some reason, and so Jawhar sent to Haftakin proposing terms of peace. It was agreed that Jawhar should pay a compensation to Haftakin and then both he and his men should be allowed to go away in peace, but should pass under Haftakin's sword. This was agreed and Haftakin's sword was suspended over one of the gates of Ascalon, and the Egyptian army moved out through this gate and marched homewards by the road through Ramla. On the way they met al-'Aziz marching to their relief, and the two forces joined together and turned back upon Haftakin. He was at Tiberias when he heard of this meeting and at once set out, and before long came into contact with the Fatimite army, with the result that the Turks were put to flight after an engagement lasting only a few minutes. This took place on Thursday, seven days before the end of the month of Muharram 368 . Haftakin's body was sought amongst the many slain but was not found: later on he was brought in a prisoner by some Arabs who had taken him in flight. He was led before al-'Aziz, who ordered him to be paraded through the troops, during which he had his beard pulled, and had to endure blows and insults of all sorts. The Fatimite then returned to Egypt carrying with it Haftakin and many other prisoners.

When the Khalif reached Cairo he treated Haftakin with every consideration, supplying him with garments and presents, and assigned him a residence. In after times Haftakin, admitted to the Fatimid court as an honoured guest, used to say : "I blush to mount my horse in the presence of our lord 'Aziz bi-llah, and dare not look at him because of the gifts and favours with which he overwhelms me." When al-'Aziz heard this he said to his uncle Haydara : "By God, my uncle. I love to see men covered with favours, shining with 
gold and silver and precious stones, and to think that all their fortune comes from me." The Khalif heard that some people found fault with his conduct towards Haftakin, and ordered him to be escorted through the city in magnificent apparel, and on his return presented him with a large sum of money, a number of robes of state, and ordered the chief men of the court to show him hospitality. After the courtiers had feasted him the Khalif asked him how he approved of their banquets, and Haftakin replied that they were magnificent and that his hosts had loaded him with presents and compliments. It was the Khalif's project to form a Turkish faction of military capacity which would counterpoise the weight of the Berber element which he regarded with some distrust. He put the Turks and Daylamites who were in Cairo as prisoners under Haftakin's command, and thus formed a bodyguard which was independent of the Berbers, on whom he and his predecessors had hitherto relied. Haftakin enjoyed the Khalif's favour until his death in 372 . Al-'Aziz suspected the wazir Ibn Killis of having caused him to be poisoned, as it was said that Haftakin had behaved scornfully towards him, and cast the wazir into prison, but after a short confinement the wazir was set at liberty as the Khalif found that he could not dispense with his services.

Ibn Killis served as wazir in all for fifteen years (d. 368 ), and it was largely due to him that the country enjoyed internal peace and that the public revenue was largely increased. For the next two years the wazir was the Christian 'Isa b. Nestorius, who was supported by harim influence. In fact the only efficient administrators were to be found amongst the non-Nluslims and renegades: the Turks and Berbers were all right as fighting men, but could never learn to act efficiently as civil servants. But these appointments were not popular, and evidences of resentment appear from time to time. When, towards the end of the reign, i preparations were being made against the Greeks, and a fleet of 600 (ships lay ready at Maqs to support the army in an expedition to Syria, eleven of these ships were set on fire, and popular feeling ascribed this disaster to the Greek inhabitants living in the neighbourhood, with the result that there was a riot in which many Greeks 
were murdered and their houses pillaged. It is not fair, however, to represent this as an anti-Christian movement, although no doubt most of those who suffered were Christians. The riot was soon put down, for al-'Aziz brought out his bodyguard of Turks and Berbers, and within six months the energy of Ibn Nestorius produced six new vessels of the newest type.

Al-'Aziz shared the besetting weakness of all the Fatimids in his uncontrolled love of ostentatious display. In his case this not only took the form of magnificent dresses and lavish generosity, but he showed a marked passion for rarities of every sort. At his table there were the most curious and foreign dainties, strange animals were imported to grace his public processions, and robes of costly and hitherto unknown materials were procured from the most distant lands. At the same time al-'Aziz was an expert in precious stones and articles of vertu, and formed a collection of such things in his palace. On the other hand he was a strict reformer in matters of finance, putting down the taking of bribes and presents with severity, and introducing the custom of paying every official and household servant a fixed salary.

Syria still remained subject to Fatimid rule, but was held only by force of arms. In 368 al-'Aziz judged it expedient to visit the country where hostile movements were taking place on the part both of the Turks and of the Greeks. At the beginning of the journey, however, he was taken ill at Bilbays. For some time he lay in a dubious state, then rallied, and then became worse again. On Sunday, the 23 rd of Ramadan, he rode to the bath, and thence to the lodgings of Barjawan his treasurer with whom he stayed, but next morning was very seriously worse. The complaint was stone with pains in the bowels. On the following Tuesday he felt that his end was near and sent for the Qadi Muhammad b. an-Numan, and the general Abu Muhammad alHasan Ibn 'Ammar, to whom he commended the care of his son, then only eleven years old. After this he sent for his son, al-Hakim, and of that interview alMusabbihi said: "In a conversation I had with al-Hakim, we happened to speak of the death of al'Aziz, on which he said to me: 'O Mukhtar, my father sent for me before he breathed his last, and I found 
him with nothing on his body but rags and bandages.' I kissed him, and he pressed me to his bosom, exclaiming: "How I grieve for thee, beloved of my heart,' and tears flowed from his eyes. He then said: 'Go, my master, and play, for I am very well.' I obeyed and began to amuse myself with sports such as are usual with boys, and soon after God took him to himself. Barjawan then hastened to me, and seeing me on the top of a sycamore tree, exclaimed: "Come down, my boy; may God protect you and us all.' When I descended he placed on my head the turban adorned with jewels, kissed the ground before me, and said: "Hail to the Commander of the faithful, with the mercy of God and his blessing.' He then led me out in that attire and showed me to all the people, who kissed the ground before me and saluted me with the title of Khalif "' (Ibn Khall. iii. 529).

Al-Musabbihi says that after this interview with his son he became worse. For some time he remained in his bath, and then as he left it, suddenly expired. The historian of Kairawan says that the physician prescribed a potion which was wrongly made up and that this was the cause of his death. 


\section{$\mathrm{X}$}

\section{THE SIXTH FATIMID KHALIF, AL-HAKIM (A.H. 386-4I I =A.D. 996-IO2 I)}

Al-Mansur Abu-'Ali al-Hakim bi-amri-llah (" . . . ruling by God's command "), commonly known as AlHakim, was only eleven years old when he was saluted as Khalif at Bilbays on Tuesday, the $23 \mathrm{rd}$ of Ramadan 386 (October, 996 A.D.). Next day he proceeded to Cairo with all the court. Before him went his father's body in a litter borne on a camel, the two feet protruding. The young prince was clothed in a woollen shirt split up the front and adorned with buttons and button holes, and on his head was the jewelled turban which served as the official diadem; in his hand he bore a lance and a sword depended from his neck (Maqrizi ii. 285). He reached Cairo and entered the palace a little time before the hour of evening prayer, and the following night was occupied with the funeral of the deceased Khalif. Ibn an-Numan washed his late master's body, which was then buried in a chamber of the palace beside the tomb of his predecessor, al-Mo'izz (Maqrizi loc. cit., Ibn Khallikan loc. cit.).

On Thursday morning the whole court attended early at the palace. A golden throne covered with cushions of cloth of gold was placed in the great portico which al-'Aziz had constructed in 369. Al-Hakim started out from the palace on horseback wearing the jewelled turban. At his approach all the courtiers kissed the earth, and then walked at his side or before and behind until he reached the portico, where he dismounted and took his seat on the throne, the courtiers taking their places according to rank, and each in turn did homage. Barjawan, the white eunuch whom al-'Aziz had appointed to act as Ustad or " tutor," administered the oath, and the young Khalif was proclaimed with the title al-Hakim bi-amri-llah. 
There is no doubt that al-'Aziz, in appointing Barjawan as tutor intended him to act as regent until the young prince was old enough to assume the power himself, although Ibn 'Ammar and the Qadi Muhammad b. Nu'man were associated with him as guardians. But at this point Ibn 'Ammar, the acknowledged leader of the Katama party in Cairo, seized the office of IV asita or chief minister, to which was united the office of sifara or secretary of state, ejecting Isa b. Nestorius, and assumed the title of Amin ad-Dawla or "the one trusted in the empire." This was the first time that the term " empire" was employed in the Fatimid state and, as De Sacy points out (Druszs i. cclxxxv.), its use shows the appearance of a new tendency. So far the Fatimids had been the leaders of a sect of which the Imam was supreme pontiff : circumstances had enabled the sect to establish a state, first in Ifrikiya, then in Egypt, but it retained, at least in theory, a quasireligious character, and its professed duty was to maintain the divine right of the Mahdi and his descendants. It seems, however, that by this time there were some who had out-grown this sectarian point of view and desired the Fatimid state to pose frankly as a secular power. The Berber tribe of Katama appears to have been the centre of this change of view; they considered no doubt that they had been the conquerors of Ifrikiya and of Egypt, and by their conquest had established a Berber monarchy : why should the fruits of this conquest be laid at the feet of an Arab dynasty whose supernatural claims they no longer believed?-the Fatimid Khalifs had given no evidence of miraculous powers, but were evidently ordinary human beings whose kingdom had been secured by the ready credulity of their forefathers. Ibn 'Ammar comes forward as the leader of what we may term the secular party, and his programme seems to have been to dispense with the religious claims of the Fatimids, and to treat Egypt and its subject provinces simply as a dawla or temporal kingdom. No doubt these views had been gathering force for some time past, and certainly al-Aziz had been more prominent as the secular ruler and had allowed the sectarian propaganda to drop into the background, but his death and the accession of a child Khalif offered exceptional opportunities for modifying 
the policy of the state. De Sacy suggests that Ibn 'Ammar's party was disposed to get rid of the young sovereign and to establish a purely Berber government, a suggestion which has every appearance of probability. With the disappearance of the divinely appointed Mahdi and the end of the Fatimid line the country would be set free from the peculiar religious views of the Isma'iliya, which were an actual barrier to the progress of the state and alienated from it the bulk of the subject population. It seems a very probable picture of the tendencies prevailing at the moment and rests upon rather more than simple conjecture, though it must be admitted that none of the native historians attach this deep significance to the introduction of the term dawla.

It is not necessary to suppose that Barjawan was a devout supporter of Isma'ilian views, but he certainly was the decided opponent of Ibn 'Ammar who had curtailed his power and thrust him into the background, leaving him to be no more than the private tutor of the young prince. By force of circumstances he was compelled to become the champion of the young Khalif, so that this first period of al-Hakim's reign centres in Barjawan's intrigues to get rid of Ibn 'Ammar.

Very early in al-Hakin's reign these came to Egypt as a refugee the eunuch Shakar, who had been a servant of the Buwayhid prince Adhad ad-Dawla, but who had been taken prisoner by the rival prince Sharif ad-Dawla, from whom he had escaped. He was a friend of Manjutakin, the governor of Syria, and Barjawan, having enlisted his support, used him as the medium of sending an appeal to Manjutakin to deliver him and the Khalif from the bondage in which they were kept by Ibn 'Ammar. Manjutakin, who was naturally inclined to be a partisan of the Turks and the Turkish mercenaries whom al-'Aziz had introduced into Egypt as a counterpoise against the influence of the Katama and other Berber tribes, readily espoused Barjawan's faction and essembled troops preparatory to an advance upon Egypt. As soon as Ibn 'Ammar heard of this he treated it as a revolt, and sent out an army under the command of Sulayman b. Ja'far b. Fallah, a Berber of the Katama tribe and one of his 
supporters to check the revolted Manjutakin. Thus the palace intrigue between Ibn 'Ammar and Barjawan was fought out by their respective supporters in Syria.

Sulayman met Manjutakin either at Ascalon or Ramla, and there he inflicted a defeat upon the Turks in which Manjutakin himself was taken prisoner and sent captive to Egypt. He was well received by Ibn 'Ammar, who wanted to see Berbers and Turks united in resistance to the established Khalifate, and perceived very clearly that his plans could not be successful unless he enlisted the sympathy of the Turkish faction which was very strong in Cairo.

After his victory over Manjutakin Sulayman was made governor of Syria and proceeded to Tiberias, sending his brother "Ali to act as his deputy in Damascus. But the citizens of Damascus, always turbulent and independent, refused to accept 'Ali as governor or to allow him to enter the city until they received a threatening letter from Sulayman which thoroughly frightened them and put an end to their opposition. "Ali entered Damascus in no pleasant mood, and made his irritation felt by turning his soldiers loose, so that many of the citizens were slain and some parts of the city burned, after which he withdrew and pitched camp outside. Not long afterwards Sulayman himself arrived and received the apologies and protestations of loyalty of the citizens and was pleased to express his pardon. It was his aim at this time to continue the policy of al-'Aziz and to hold the sea coast as a check upon the Greeks, and thus had no desire to be embroiled with a city in his rear which he left to be dealt with at a more convenient time. The Syrian Tripoli was the most important coast town held by the Muslims, and this he now handed over to his brother "Ali, dismissing the governor Jaysh, although he was a fellow Berber and a tribesman of the Katama, with the result that Jaysh went back to Egypt with a grievance and joined himself to Barjawan's faction.

Barjawan's intrigues had now so far succeeded that he had a strong following, and as most of Ibn 'Ammar's troops were absent in Syria it seemed a favourable moment to strike his rival. For some time there were street riots between Berbers and Turks, indeed, this seems to have been more or less the normal state of 
Cairo at the time, for in spite of the good treatment accorded to Manjutakin, the Turkish mercenaries were deeply jealous of the favour shown by Ibn 'Ammar to his fellow Berbers. When Barjawan felt that the time was ripe he secretly distributed largess amongst the Turks, and they made an open attack upon Ibn 'Ammar which compelled him to conceal himself and to retire from public life.

At Ibn 'Ammar's downfall, for this it actually was, Barjawan assumed the offices of Wasita and Sifara, thus becoming practically regent of the state, on 28 Ramadan 387 , after Ibn 'Ammar had held office for a little less than eleven months. He treated the fallen minister as a kind of usurper who had tried to make the: Khalif a prisoner and celebrated his own accession, or rather restoration to office-for he had certainly acted as chief minister for the first few days of al-Hakim's reign-as a vindication of the Khalif's rights. He brought forth al-Hakim in public, had him again proclaimed Khalif, and displayed him as sovereign.

But it was in Syria that the two factions were really fighting out their quarrel, and Barjawan's first act of policy was to write to the citizens of Damascus urging them to resist Sulayman, and assuring them of the support of the home government as the Katama faction had now fallen from power. Thus encouraged the people of Damascus pillaged Sulayman's goods, slew many of his men at arms, and expelled him from the city.

Neither faction at Cairo was strong enough to proceed to extremities, and Barjawan had reason to dread the return of the Berber troops from Syria. For a while Ibn 'Ammar was treated as a prisoner of state and confined to his house, but all his fiefs and sources of income were secured to him and, after an interval, he was allowed to go about as he pleased and to present himself at court.

In Syria a period of disorder followed the fall of Sulayman, and the Bedwin phylarch Mufarraj b. Daghtal b. Jarrah broke out in revolt, established his headquarters at Ramla, and made forays in the Bedwin fashion through the surrounding country. At the same time Tyre revolted under the leadership of a peasant named Olaka, and the Greeks, led by the Emperor Ducas, laid 
seige to Apamea. It seemed, therefore, that Barjawan's success involved the practical loss of control over the Asiatic provinces. But though Barjawan had encouraged the turbulence of the Damascenes for his own purpose, and had thus got rid of Ibn 'Ammar's chief supporter Sulayman, he bad no intention to lose hold of Syria permanently, and sent up Jaysh b. Samsama as governor: probably this appointment was Jaysh's stipulated fee for assisting Barjawan. At the head of a large force Jaysh proceeded to Ramla where he found Sulayman whom he made prisoner and sent to Egypt. He then sent a detachment under IIusayn b. 'Abdullah against Tyre, and proceeded himself against Mufarraj.

At Husayn's approach Olaka appealed for help to the Greek Emperor, and in response a fleet of Greek ships was sent to his assistance. These ships, however, were met off Tyre by an Egyptian fleet and defeated. The Tyrians, now thoroughly discouraged, made an unconditional surrender and Husayn entered their city, pillaged it, and sent Olaka a prisoner to Egypt where he was flayed and crucified.

Meanwhile Jaysh had been advancing against Mufarraj but, as he approached with so large an army, Mufarraj became frightened and fled. Jaysh did not pursue him but passed on to Damascus where the inhabitants received him with some anxiety, although in their recent revolt against Sulayman they had been acting, with the approval and encouracement of Barjawan's faction, and so in alliance with Jaysh. They remembered, however, that Jaysh was a Berber of the Katama, and that tribal prejudices were stronger than any temporary association in palace factions. As soon as Jaysh entered the city he made a reassuring speech to the people, and the citizens were fully convinced that he intended only friendly relations. At the moment he was most anxious to be free from any minor troubles with the cities of Syria in order that he might deal effectually with the Greek attempts upon the country which, for some years past, had been growing more serious. He proceeded therefore to Apamea, and before long joined issue with the Greek forces under Ducas, and received at their hands a severe defeat. Whilst the Muslims were in full flight and the Greeks were occupied in plundering their baggage, a young 
Kurd named Ahmad ibn 'Abdu-1-Haqq, with a small band of followers of the tribe of Bashara advanced to where the Emperor stood surrounded by officers amongst whom was his son. The Emperor paid no attention to the Kurd, supposing him to be one of the defeated enemy coming to make formal surrender, but as Ahmad drew near he fell upon the Emperor with his sword and killed him instantly. At this the Greeks were thrown into confusion, the Muslims rallied, and the conflict closed with a victory for the Muslims.

Jaysh, thus unexpectedly the victor, proceeded to Antioch, but did not think it worth while to spend time in a seige without which it would have been impossible to enter the city, and so taking what booty and prisoners he could get in the neighbourhood, he went back to Damascus. He was now free to give vent to his long standing grudge against that city. Refusing all invitations to enter within its walls he pitched camp outside, but continued his friendly attitude towards the citizens, and frequently inviting the leaders of the local bands, - whether they should be called militia or brigands is dubious, - entertained them in his tent. On these occasions the guests feasted with Jaysh and then, instead of having water brought round to wash their hands, they used to be conducted to a separate room and washed there. This went on for some time, and then one day the door of the room where they had retired was closed, the guests were trapped and led out one by one to execution. As soon as the citizens heard of this they were thrown into great alarm. Next day Jaysh entered the city, executed as many leaders of the local bands as he could find, seized many of the prominent citizens and sent them prisoners to Egypt, and then pillaged their houses.

Thus Syria was brought to a condition of comparative order. Meanwhile Barjawan had sent forces to reduce Barqa and the African Tripoli, and thus the whole Fatimid Empire was brought to subjection. The Katami Fahl b. Isma'il was appointed governor of Tyre, the eunuch Yanas was put in charge of Barqa, and the eunuch Maysur was given the African Tripoli, whilst the frontier posts of Gaza and Asqalon were entrusted to the eunuch Yaman. But more important than any of these arrangements was Barjawan's great 
achievement in sending an embassy to the Greek Emperor and concluding with him a truce for five years.

Although Barjawan remained for nearly three years regent of Egypt, Syria, North Africa, and the Hijaz, his position was far from secure. His danger came from an unexpected quarter; not from the Katama faction and Ibn 'Ammar, but from the young Khalif who was beginning to resent Barjawan's conduct as regent. According to one account the feeling was personal and largely due to Barjawan's manner towards his ward, whom he seems to have treated with contempt and active dislike, applying to him the nick-name of "lizard." For a long time al-Hakim nourished his resentment in secret and then, four days before the end of Rabi" II., in the year 390, he sent to him the message, "The little lizard has become a great dragon and wants you." Much alarmed, Barjawan presented himself before the $K$ halif, and was slain by Abu l-Fadl Raydan, the bearer of the royal parasol, who stabbed him in the belly with a knife (cf. Ibn Khallikan, i. 53). Whatever measure of truth there is in this account it probably hits off some salient features in the way that a caricature sometimes gives a truer portrait than a photograph. Undoubtedly alHakim was quick to feel resentment, many proofs of this appear in his later life; and undoubtedly there was already something uncanny in his actions and manners, the symptoms in all probability of incipient insanity; and no doubt interested persons were busy if fanning the smouldering embers of resentment. Other accounts, reported by Nowairi and Bar Hebraeus, the former always a most weighty authority for this period, represent al-Hakim as chafing at Barjawan's control, at his confinement to the precincts of the palace and at the prohibition against his riding abroad, the declared reason being the fear of assassination at the hands of the Katama partisans, which may have been not without good ground. According to these two historians the whole plot was due to the parasol bearer Raydan, who had become the Khalif's confidant, Barjawan being occupied with matters of state and wasting no time with the youth who was the titular sovereign and who, it may be supposed, was ai moody 
and unpleasing personage, and thus the parasol bearer was able to persuade his master that Barjawan was trying to emulate Kafur, and intended to make the Khalif a merely ornamental figure kept in the palace, and brought out from time to time to grace some state function. It lent colour to this, that Barjawan's mode of life was strangely reminiscent of Kafur; after he had secured the command of the government he had gradually relaxed his attention to public business, until at last his life was spent entirely in pleasure, but he never attained the literary interests of the former negro ustad.

Nowairi tells us that al-Hakim, influenced by the suggestions of Raydan, had consulted Husayn, the son of the great general Jawhar, and that he frankly advised him to get rid of Barjawan. Although the minister no longer troubled to supervise the Khalif's education, it was his custom to take him from time to time for a walk in the gardens which had been laid out by Kafur, the gardens of the Pearl Palace, as they were called. It was decided that some such occasion should be used to dispose of Barjawan, and so one day as he was thus walking with al-Hakim Raydan suddenly attacked him and drove a lance into his back, then al-Hakim's servants crowding round cut off his head.

Barjawan's assassination was followed by a riot. The people of Cairo were not insensible of the general security and peace which his rule had secured, and feared a return of disorder. But Nowairi tells us that the report went abroad that Ibn 'Ammar had made an attempt on the Khalif's life. This is likely enough, for Barjawan had constantly kept alive the idea that the Khalif lived in perpetual danger of Katama attacks. Other accounts attribute the riot to Barjawan's popularity and to resentment at his murder and fear of resulting relaxation of the strong hand which had guided the country into ways of peace and prosperity. This riot was al-Hakim's first lesson of the need of tact in dealing with his subjects. He was never lacking in personal courage, and on this occasion he went out to the people and declared, "I have been informed of an intrigue which Barjawan made against me, and for that I caused him to be executed. I beg 
you to take my part and not to be hard on: me, for I am yet a child," and he burst into tears. The " intrigue" thus referred to was no doubt the conspiracy which Raydan maintained that Barjawan had formed to treat the Khalif in the same way as Kafur had treated the later Ikhshid princes.

Although al-Hakim was now in the fifth year of his reign he had as yet taken no part in the government, which was of course the result of his tender years. It is obvious, however, that he had come under the influence of Barjawan and then of Rayad and Husayn, who had all endeavoured to develop his self-assertion for their own ends. As yet his personal character was quite unknown, and the expansion of his personality lies within the period following Barjawan's assassination.

Thus the death of Barjawan marks the beginning of the second period of al-Hakim's reign, during which he began to assert himself and to display his own character, although in this we see very distinct graduations which tend to produce marked differences of policy. The first phase covers the years 390-395, in which he shows marked peculiarities, and we note an increasing fanaticism in upholding Shi'ite views, but for the most part he is inclined to pleasure, and seems to have been popular. In 395-396 there comes a puritan reaction, associated with a time of distress and famine in Egypt, which becomes more pronounced as he has to meet revolt at home and hostile invasion from the west.

After Barjawan's death al-Hakim chose Husayn, the son of Jawhar, as his chief minister, the same adviser whom he had consulted about Barjawan, and who had advised his murder. Husayn received the title of Qa'id al-Quwwad, " general of generals," or Commander-in-Chief, and a Christian named Fahd acted as his lieutenant. Fahl b. Tamim was made governor of Damascus but, as he died shortly afterwards, he was replaced by 'Ali b. Fallah. An order was made very early in this period forbidding any person to address the Khalif as " our lord " or "our master," and requiring them to confine themselves to the simpler title "Commander of the Faithful," and this order was enforced with the penalty of death. 
Now al-Hakim, feeling himself free from restraint, began to show evidences of peculiarities which caused many of his day and many since to regard him as a person of disordered intellect. His first peculiarity was a preference for night over day. He began to hold meetings of the "council" by night, whether of the council of state or the religious assembly of the Isma'ilian sect does not seem quite clear, he rode abroad in the city by night, and by his orders the streets were brightly illuminated, the shops opened, and business and pleasure followed by artificial light. The citizens vied with one another in hanging out lights and illuminating their houses to win the Khalif's approval. This continued for about five years, during which alHakim seemed disposed to encourage every kind of pleasure, and every night saw both Cairo and the old city of Fustat refulgent with artificial illumination. In his conduct generally the Khalif was tolerant, as his predecessors had been, towards the Christians and Jews as well as towards the Muslims who did not embrace the peculiar tenets of the Shi'a sect. His mother was a Christian. Towards his officials his conduct was generous, and he seems to have been distinctly popular. Thus, when Jaysh died in 390 his son went to Cairo with a paper on which his father had written his will and a detailed statement of all his property : all this, he declared, belonged to the Khalif his master; his children had no rights. The property thus valued was estimated at 200,000 pieces of gold. The son brought all this before the Khalif, but alHakim said, "I have read your father's will and the statement of the money and goods of which he has disposed by his will : take it, and enjoy it in tranquility and for your happiness." Indeed, all through his career the chief charge made against him was his reckless generosity, which often reduced the government to serious inconvenience : it was, indeed, a species of megalomania.

No doubt the nocturnal festivities of Cairo, well suited to the pleasure loving character of the Egyptians, led to many abuses, and so in 391 a strict order was issued forbidding women to go out of doors by night, and a little later this was followed by a general order prohibiting the opening of the shops by night (Maq. ii. 
286). Al-Hakim himself continued his nocturnal tastes and nightly wanderings in the city until 393, when he entirely ceased riding about by night and forbade any person to be out after sunset.

In 393 al-Hakim began to show other curious developments in his conduct, the external signs, it would appear, of a growing disorder of the mind. We do not know what grounds Barjawan had for calling him a lizard; very possibly there was something furtive and uncanny in him even in his boyhood. In the early years following the death of Barjawan he seems to have been genial and generous, but all this changed in 393, when his character began to show a rigorous puritanism and signs of religious fanaticism, which indeed need be no sign of a disordered intellect, but which, suddenly developed, might very well accompany such a thing. It was in this year also that he began to be active as a mosque builder and as a generous benefactor of existing mosques, though this again is no evidence of disordered mentality. At the same time he became fanatical in his support of the peculiar tenets of the Shi'ite sect to which he belonged, and began to show great severities towards Christians and Jews, although in this last item he seems to have acted under the pressure of public opinion, which was very decidedly irritated by the favouritism which the Fatimids had so far shown to non-Muslims. But side by side with this sudden puritanism and fanaticism appeared a vein of capricious cruelty which has a very sinister bearing. Such cruelty begins to be prominent in 393 when many persons were put to death, some on religious grounds, others it would appear merely by a passing caprice of the Khalif. Amongst these was the Ustad Raydan, the royal parasol bearer who had counselled the murder of Barjawan.

In 394 the Chief Qadi Husarn b. Nu'man was deprived of his office and replaced by 'Abdu 1-Aziz b. Muhammad b. Numan, who had been acting as Inspector of Complaints. In every Muslim country the Qadi who administers the sacred law is a person of very great importance, but under the Fatimids the Chief Qadi very often also held the office of Chief Da'i or Supreme Missionary, as was the case with Husayn. If the two offices were held by different persons the 
Chief Da'i ranked next after the Chief Qadi, and wore a similar official costume. It was the duty of the Chief Da'i, who had under him twelve assistants a's well as subordinate da'is in the different provinces, to receive the conversions of those who joined the Isma'ilian fraternity, and to deliver regular courses of instruction to those who were members, according to their grades in the society. His official income was derived from a fee of three and a half pieces of silver from each member. In earlier times, as we have seen, the da'is were chosen from the most earnest proselytes, but at this period the office of Chief $\mathrm{Da}$ ' $\mathrm{C}$ was hereditary in the family of the B. 'Abdu 1-Kawi, and in them we may be disposed, perhaps, to recognise " the power behind the throne." Still it does not seem that this hereditary right was treated as essential for the office, but only that it was usually regarded as giving a normal qualification.

The appointment of a new Chief Da'i brings us to the period of al-Hakim's puritanism. It was a time of great dissatisfaction. Even a people so habitually patient as the Egyptians were beginning to feel irritation at the expense involved in the nightly illuminations so long continued. A more serious cause of discontent was that which usually lies behind every disaffection in Egypt, a failure of the inundation of the Nile. For three years in succession the Nile flood had been exceptionally low, and so food was scarce and dear.

In 395 , when a great number of people were executed, the ex-Qadi Husayn b. Nu'man was put to death and his body burned. We note elsewhere the peculiar proIsma'ilian legislation of 394 against various vegetables which were traditionally associated with persons who appeared in history as hostile to the house of 'Ali (cf. p. I4 I below). At the same time a prohibition was issued against the slaying of oxen, other than those injured or diseased, save at the Feast of Sacrifice (Maq. ii. 286, Ibn Khallik. iii. 45o), a prohibition perhaps connected with the scarcity due to the bad Niles.

We have already seen that strict laws against going out at night were made as the result, no doubt, of abuses arising from the nightly illuminations and merry-making. Now, in 395, more stringent regul- 
ations were made. It was enacted that no women were to appear in the street unveiled, and that no persons were to use the baths without wearing wrappers. In Jumada II. of this year, a general prohibition was issued against any persons going out of doors after sunset, so that the streets were deserted by night. In accordance with another law all vessels containing wine were seized, the vessels broken, and the wine poured out (Maq. ii. 286). Another law dealt with the dogs which roam about most eastern cities and who, in Muslim lands are savage because they lack human intercourse, for the religion of Islam has placed the dog and the pig apart as animals who are in all circumstances unclean, so that no one who has touched either of these is able to pray or eat without formal ablution. Now al-Hakim commenced a war of extermination against dogs, with the result that in Cairo many were slain and very few could be seen in the streets. Severus says that this rule was made because al-Hakim's ass had taken fright at a $\operatorname{dog}$ barking at it: in strict accuracy the Khalif had not at this time adopted the custom of riding an ass, but this is a minor detail.

Stricter rules also were made excluding ordinary civilians from Kahira, from which it appears that the seclusion of the guarded city had been somewhat relaxed. In future no one was to be allowed to ride into it, but must dismount and proceed on foot, and all those who let out asses for hire were to be excluded from its precincts, whilst no one was to be allowed to pass in front of the royal palace even on foot.

We must now turn to consider conditions in Syria, for it is always impossible to understand Egyptian history unless the course of events in Syria is kept in view. At the time of Barjawan's death Syria was under the governorship of Jaysh, but when he died in 390 it became necessary for al-Hakim to nominate a sucressor for this important post. He chose Fahl of the B. Tamim, but Fahl died after only a few months. The Khalif then appointed 'Ali b." Fallah of the Katama. In 392 the Hamdanid prince of Aleppo, Sa'id ad-Dawla, and his wife, were poisoned by his father-in-law Lu'lu', who desired to obtain the throne for himself. He did not seize the supreme power immediately, but proclaimed Sa'id's two sons 'Ali and 
Sharif as joint rulers, retaining the real control in his own hands. This continued for two years, then in 394 ine sent them together, with the whole of the harim of the Hamdanids to Cairo, and assumed to himself the office and title of Emir in conjunction with his son Mansur, and these two ruled as Emirs under the protection of the Fatimid Khalif until Lu'lu"s death in 399. Then Mansur became sole ruler under the title of Murtada l-Dawla which was conferred on him by alHakim, and he had the name of the Fatimid Khalif inserted in the Friday prayer and inscribed on the coinage so that by 399 Aleppo was fully admitted as a part of the Fatimid empire, having been a protected district for the previous five years, before which it had for forty years been included in the Byzantine Empire.

The first evidence of al-Hakim's strong religious interest appears in his diligence as a builder of mosques, and in the completion or adorement of those already erected.

A mosque near the Bab al-Futul, the second congregational mosque of Kahira, had been commenced by al-'Aziz and the Wazir Ibn Killis in 380 , and was sufficiently advanced to allow the Friday prayers to be held there in $38 \mathrm{I}$. In 394 al-Hakim added the minarets and the decorations so that Maqrizi describes him as reconstructing the building. The work was not conpleted until 404. At first known as the "New Mosque" or as al-Anwar " the brilliant," it afterwards generally bore the name of Hakim's Mosque. Desecrated by the Crusaders, severely injured by an earthquake in 703 , it was in a semi-ruinous condition by fire and neglect with its roof falling to pieces when Maqrizi wrote his description of it about A.H. 823 (=A.D. 1420 . Cf. Maqrizi ii. 277, sqq.). After even worse decay in later days it was temporarily converted in recent times to a museum of Arabic art, the collection being removed to its present quarters in 1903 . The mosque is now abandoned and in ruins. Its general plan follows that of the mosque of Ibn Tulun, a square courtyard surrounded with arcades, the centre open to the sky. A considerable part of the east liwan remains, with a few fragments of the north liwan, of the other two sides only portions of the exterior walls survive. Two 
towers can be seen standing at the ends of the west wall, but the open-work minarets which crown these towers are additions made some three centuries later and alien to the style prevailing in the time of the Fatimids.

In the year 393 al-Hakim also began to rebuild the mosque in the district of Rashida to the south of Katai" near the Mukattam hills, on a ground where a Christian church had once stood. The mosque had been built of brick; this al-Hakim destroyed and re-constructed on a larger scale and of more imposing appearance. It was known as the mosque of Rashida from its position, the ground being so called after a person of that name who had once been its owner. This mosque was commenced in Rabi" I. 393, and the position of the mihrab was carefully adjusted by the astronomer 'Ali b. Yunus. Two years later the Khalif made this mosque a present of carpets, curtains, and lamps.

Besides this building al-Hakim made many gifts to various mosques, especially to those he purchased for the special purposes of the Shi'ite sect, presenting them with copies of the Qur'an, silver lamps, curtains, Samanide mats, etc.

The earlier Fatimids in North Africa present rather a brutal appearance and, so far as we can see, their one ideal was the establishment of political power. But that was not the original character of the movement which had distinct intellectual tendencies, and to this earlier type al-Mo'izz had reverted. Since the dynasty had been established in Egypt the humane side had been more prominently in evidence, and especially in the encouragement of medicine and natural science. The Khalif al-Mo'izz employed the Jewish physician Musa b. al-Ghazzan and his two sons Ishaq and Isma' $\mathrm{il}$ : these were not only eminent practitioners but Musa was distinguished as a writer on the pharmacopia, and all three were regarded as leading authorities on medicine. Another distinguished physician was the Christian Eutychius or Sa'id h. Batriq, patriarch of the Malkite church of Alexandria who died in 328 (=A.D. 943), the author of a history of which an edition in Arabic and Latin was published at Oxford in 1654 .

Al-Hakim himself was anxious to encourage scholarship in accordance with the traditions of the sect of which he was the head. The mosque of al-'Azhar had 
been especially devoted to the learned by his father, and now in Jumada II. 395 he founded an academy on the lines of similar institutions already existing at Baghdad and elsewhere. This new foundation was named the Dar al-Hikma or " house of wisdom." To it were attached a number of professors, both of the traditional sciences and Qur'an and canon law, and also of the natural sciences. A library was connected with it and was filled with books transferred from the royal palace near by. All who came to it were supplied with ink, pens, paper, and rests for books.

It seems probable that the intellectual efforts of the Fatimids should be connected with the Ikhwanu s-Safa, " the brotherhood of purity" and with the Assassins. The former began as a kind of masonic society at Basra soon after the capture of Baghdad by the Buwayhids in 334. Undoubtedly it had some connection with the sect established by "Abdullah the son of Maymun, but it is not possible to specify accurately what that connection was. It may have been a more cultured offshoot, just as the Qarmatians were a cruder branch; but the more probable explanation is that it was a descendant of the movement which produced 'Abdullah, but free from the Shi'ite elements which he inherited from the sect founded by his father Maymun. To a large extent it seems that the "Brotherhood" displayed the true principles adopted by the Isma'ilians free from the Shi'ite ideas and free from the political opportunism which marked the development of the Fatimids in Africa and Egypt. To the Assassins we shall have occasion to return at a later stage. The " Brethren of purity" were disposed in four grades, the highest of which was composed of those who desired the union of their souls with the worldspirit, so that their final doctrine was a species of pantheism. They were a body of religious and ethical reformers, a purified and gentle society, at the opposite pole to the fierce Qarmatians. On the literary side they are best known as the producers of the fiftyone "Epistles of the Brethren of Purity," an encyclopaedia of philosophy and science as known in the Arabic speaking world of the fourth century. These "Epistles" were edited and translated by Prof. Dieterici between $185^{8}$ and 1879 , and show a general 
scheme of education in grammar, theology, philosophy, and physics, the latter including mineralogy, chemistry, botany, and zoology. It is in no sense an original work, but simply an encyclopaedic compilation of all the material then available.

The whole Fatimid movement took place in an atmosphere saturated with Hellenistic thought, and the revived study of the Greek material was the direct inspiration both of the Isma'ilian sect as organised bv "Abdullah and of the "Brethren." But the influence of these latter was checked by the strong tendency towards reaction in Muslim theology and thought generally which was gathering even in the fourth century in Asiatic Islam. The future of the philosophers lay in the far west: Ibn Sina (d. 428) was the last of the Muslim philosophers in the east, and he was associated with Shi'ite circles, whilst al-Farabi had lived under the shelter of the Shi'ite Hamdanids, and the "Brethren" flourished under the Buwayhids who also were Shi'ites. For the most part the study of Greek philosophy, therefore, progressed under Shi'ite influences.

The "House of Wisdom" continued until 513 when the reactionary wave of orthodoxy had reached even Fatimid Egypt, and in that year it was closed as a home of heresy by the Wazir Afdal. Four years later a new academy near the great palace was founded by the Mazir Ma'mun, but this adhered more strictly to the traditional lines of Muslim study.

In the line of philosophers strictly so-called, that is to say, of those who worked from the basis of Greek science, one is associated with al-Hakim and the Cairo of the Fatimids, namely, Ibn al-Haytsam, known to the mediaeval Latin writers as Mlahzen. He was born at Basra in 3.54, and became distinguished as a student of the Greek philosophers. At that time the path of philosophy was beset with many difficulties owing to the orthodox reaction.

Ibn Sina was a wanderer in many lands, and Ibn al-Haytsam found it more piudent to seek a refuge in Cairo where he made his home amongst the learned of the al-Azhar mosque. He died in 4,30 . ITe have a long list of the works he produced, all of the type usually associated with the Arabic philosophers, 
manuals, commentaries, and discussions of questions arising from the teaching of the ancients. In his case these deal chiefly with mathematics, physics, the Aristotelian logic, and the medical works of Galen. The Bodleian contains a MS. of his commentary on Euclid. To the mediaeval west he was best known as the author of a treatise on optics which was translated into Latin and used by Roger Bacon. Occasionally this optical work of "Alhazen" appears in the curricula of the mediaeval universities.

Various evidences of a fanatical spirit in maintaining the doctrines and usages of Shi'ism begin to appear in al-Hakim about 393. In Syria a person was arrested on the charge that he denied that any special devotion was due to "Ali. The offender was imprisoned by the authority of the Chief Qadi of Egypt who acted as pope over all the territories subject to Fatimid rule, and was examined by four jurists who did their best to persuade him to recognise the Imamate of 'Ali, but, as he remained stubborn, he was beheaded.

In Cairo thirteen persons were arrested for having observed the Salat ad-Duha or " mid-morning prayer," one of the voluntary observances sometimes added to the five canonical daily prayers, but disapproved by the Shi'ites. The offenders were paraded through the streets, beaten, and detained three days in prison.

In the month of Rabi' II. of this same year (393) a man named Aswad Hakami was punished for some offence of which the details are unknown, but which probably was a public championship of the three first Khalifs whom the Shi'ites regarded as usurpers. He was paraded through the city and a herald cried before him: "This is the reward of those who are the partisans of Abu Bakr, and Umar," after which he was beheaded (As-Suyuti History, chap. I., Qadir bi-llah).

In 395 al-Hakim re-enforced many old laws against Christians and Jews, and the decrees ordering the strict observance of these penal regulations contained many abusive expressions against Abu Bakr and Umar. A new decree of 395 forbade the use of malukhiya or "Jews' mallow" as food because it was traditionally stated to have been a favourite article of $\mathrm{Mu}$ 'awiya the opponent of "Ali. Similarly the use of jirjir (girgir) or "watercress " was forbidden because it had been intro- 
duced by Ayesha : and of mutawakkiiya, a herb named after the 'Abbasid Khalif Mutawakkil. The sale or making of beer $\left(f u q q a^{\prime}\right)$ was severely prohibited because it was especially disliked by 'Ali : it was forbidden to use dalinas, a species of small shell fish, for some reason not known: and very strict orders were made against the sale or use of any fish which had no scales.

In the same year a law was published that the noon prayer was to be said at the seventh hour and the afternoon prayer at the ninth, that is to say the modern way of counting the correct hours was to be observed instead of the traditional method of observing the sun. In these cases tradition allowed the noon prayer to be said as soon as the sun is actually seen to begin its decline from the meridian (Bukhari : Sahih ix. I I), and the afternoon prayer after it has declined (id. I3, I3A). Orthodox Islam allows the former at any time between noon and the hour when the shadow of a thing is equal to the thing itself in length, and the latter at any time between the moment of equal shadow and the sunset (cf. id.). The Fatimid Khalif now replaced these very primitive methods of reckoning, which are still in force, by the observance of fixed hours as marked by the dial.

In the month of Safar of 395 al-Hakim caused inscriptions cursing the three first Khalifs, the " usurpers,"' and certain others such as Talha, Zubayr, Mu'awiya, and Amru, all regarded as enemies by the Shi'ites, to be written up on the doors of the mosques and of shops, and on the guard houses and in the cemeteries, and compelled the people to display similar inscriptions in gold lettering and bright colours (cf. Maq. ii. 286, As-Suyuti : al-Qa'im. Ibn Khall. iii. 450). These were extremely offensive to the Sunnis or orthodox who formed the large majority of the people, indeed at the present day the attitude to be observed towards the first three Khalifs is the sorest point of difference between the Sunnis and Shi'ites, and even in recent years more than one Shi'ite has risked death for the sake of spitting on the tomb of 'Umar. At the same time efforts were made to induce citizens to join the Isma'ilian sect, and two days were set apart every week for the admission of those who desired to be initiated. On some of these occasions the crowds were 
so large that several people were crushed to death (Maq. ii. 286).

Those who were keen Shi'ites naturally were encouraged by this legislation to become somewhat aggressive in their attitude. When the caravan of African, that is to say Moroccan and Tunisian, pilgrims on their way home from Mecca passed through Egypt and rested at Cairo, some of the more ardent Shi'ites tried to induce them to utter curses against 'Umar and the other early Khalifs, and the refusal of the pilgrims to do so led to some disturbances.

At the beginning of the year 396 the usual Shi'ite feast of the Ashura commemorating the martyrdom of 'Ali and his sons, a regular occasion for an outbreak of Shi'ite fanaticism at the present day, was duly celebrated on the first ten days of Muharram. This time the offensive attitude of the Shi'ites caused a good deal of annoyance, and one man was arrested for shouting : "Such be the recompense of those who curse "Ayesha and her husband."' For this he was beheaded.

In 393 al-Hakim commenced the strict observance of the old laws, now long obsolete, against the Christians and Jews. We are left in no doubt as to the reason why these ancient penal laws were revived and strictly enforced. Maqrizi tells us that it was due to the arrogance and wealth of those Christians and Jews who had been unduly favoured by the Fatimids. The greater part of the civil service was filled by them, and some Christians, such as 'Isa b. Nestorius and Fahd b. Ibrahim, were then acting as ministers of state. To a large extent we may ascribe al-Hakim's treatment of Christians and Jews as due to the pressure of public opinion, and it is rather interesting to observe how such opinion was brought to bear upon a mediaeval Khalif.

One day as al-Hakim was riding through the streets the was confronted by a female guy made of paper bearing in her outstretched hand a document which Hakim took, and read: "In the name of him who has honoured the Jews in Manasseh, and the Christians in 'Isa b. Nestorius, and has dishonoured the Muslims in himself, deliver us from the evil state we are in, in good time" (Abu 1-Feda. Annal. Mosl. ii. 591).

Hakim's first step was to endeavour to bring pressure to bear upon his chief officials in order that by getting 
them to profess Islam he might remove the objection felt towards them. One of these was Fahd b. Ibrahim, a Christian who had been ra'is or lieutenant under the commander-in-chief Husayn b. Jawhar since 389 . He, however, proved stubborn in his adherence to the Christian religion and so was beheaded and his body burned, an act of severity which was not justified bv Muslim law. As soon as the execution was over Hakim sent for Fahd's children, assured them of his protection, and forbade any one to do them harm. Fahd was succeeded in his office by the Muslim 'Ali b. "Umar al-'Addas. Hakim then made a similar attempt to convert 'Isa b. Nestorius and with similar result, so 'Isa also was beheaded. Bar Hebraeus puts this event in the period $386-389$, but as Maqrizi mentions it just before his reference to the execution of Fahd it is more probably dated 393 .

Al-Hakim had ten of the chief Christian clerks, including Fahd, arrested. The first of these to be brought before him was Abu Najah, who was a member of the Greek Church. Hakim urged him to become a Muslim, and promised him rapid promotion and immediate rewards if he would do so. Abu Najah asked that he might be allowed a day's delay, and this was granted him. He then went home and, gathering together his kinsmen and friends, told them what had taken place, and assured them that he had asked for this delay, not because he was in any doubt as to what he would do, but in order to meet them and exhort them to remain steadfast in their faith in the persecution which he fore-saw was about to fall upon the church. He then entertained them all to a feast and next day presented himself before the Khalif. Al-Hakim asked him if he had made his choice : he replied that he had done so:- "And what is your intention?"- "It is to remain firm in my religion." Al-Hakim then tried promises and threats, but without result. He then had him stripped and scourged until he had received five hundred stripes, so that his flesh was torn and the blood flowed freely. As the torturers stopped al-Hakim ordered them to continue until the sufferer had received a thousand lashes. After three hundred more Abu Najah cried out that he was in thirst and, as this was reported to al-Hakim he ordered one of the men to give 
him a drink of water. But when the water was offered Abu Najah said: "Take away his water. I have no need of it, because Jesus Christ the true King has given me to drink,"' and then he died. When this was reported to Hakim he ordered the thousand strokes to be completed on the dead body.

Of the other eight clerks remaining after Fahd and Abu Najah, four remained firm and were executed, and four turned Muslim. Of these latter one died during the night after making his profession of faith, the other three remained conforming Muslims until the penal laws were relaxed in the latter part of Hakim's reign when they returned to the Christian Church, the Khalif protecting them from the legal penalties to which this exposed them.

Towards the end of 394 Hakim began collecting a large store of wood on Mokattam, and this was completed in Rabi' I. 395. A rumour went abroad that this was intended to provide a general holocaust of nonMuslim clerks and civil officials, and a panic took place amongst the Christians. On the $5^{\text {th }}$ of that month a large number of clerks assembled at the ar-Riahin and went in procession through the streets with lamentations and cries for mercy, and finally assembled before the palace imploring the Khalif's mercy. At the palace they were met by the Commander-in-Chief, Husayn b. Jawhar, who undertook to present their petition to the Khalif. Next day they returned and Husayn gave them letters of protection written out in three forms, one for Muslims, another for Christians, and another for Jews (cf. Maq. i. 286, sq.). Although it was the clerks employed in the public service who were chiefly concerned in this, there were also merchants and private citizens who had dealings with the court who joined in the appeal and received letters of protection. Maqrizi has preserved a specimen of these letters from which we gather that they were by way of licences of toleration granted, in the case of Muslims, to those who had not become members of the Fatimite sect. The example he gives reads: "In the name of God, etc . This letter is from the servant of God and his wali Mansur Abu 'Ali the Imam Hakim bi-amrillahi, Commander of the faithful, to the people of the mosque of 'Abdullah: You are amongst those who are in safety with the 
security of God, the King, the evident Truth, and with the security of our ancestor Muhammad, the seal of the prophets, and of our father 'Ali the best of his heirs, and of the line of the prophets, and of the people of the Mahdi our ancestor, may God be gracious to the Apostle and his envoy, and to all others of them; and the security of the Commander of the faithful is upon you yourselves, upon your kindred and property. Do not fear for yourselves, let no hand be raised against you save for the punishment of wrong-doing, or for a claim made and proved. Confidence must be given to this, and one must count on the accurate fulfilment of what is above, God willing. Written in the month of Jumada II. 395. Praise be to God, may he be gracious to Muhammad the chief of the apostles, to 'Ali the best of his successors, and to the Imams of the house of the Mahdi, kinsmen of the prophet, and may abundant peace be upon them " (Maq. i. 286). We note that Muhammad is described as "the seal of the prophets" quite in the orthodox way which gives no indication of the Fatimite teaching of a subsequent prophet of greater importance in Abdullah b. Maymun. The general tone is distinctly Shi'ite, but Fatimid only in the reference to the family of the Mahdi.

Was there any basis to the rumour that a general holocaust was intended? Such a thing seems almost incredible, but there are certain signs which point in its favour. Soon after the appeal made to the Khalif in Rabi' I. he made a huge bonfire of all the wood collected, and for this there was no obvious purpose, and it is certain that he had developed a tendency to use burning as a form of punishment. We are not prepared to say, therefore, that the rumours circulated about the store of wood on Mokattam were entirely baseless.

Al-Hakim was particularly severe upon the inferior servants of the court, and especially on the runners or footmen, many of whom were put to death whilst others obtained letters of protection. This may have been an instance of religious intolerance, or simply a case of the capricious cruelty which now began to appear in Hakim's conduct and contributed so much to the theory that he was suffering from a disordered mind. 
In 395 the old penal laws dating from the year 36 were re-enforced against Christians and Jews. Both were required to wear a distinctive dress, the Christians to have turbans of black or dark blue, a custom which the Christians seem to have adopted voluntarily in the first place, and which the Coptic clergy retain to the present day, the Jews to wear yellow turbans: the women of both religions were forbidden to wear the waist sash which was a characteristic part of female attire, and the men were required to adopt it. At the same time it was forbidden to sell slaves to Christians or Jews.

The citizens of Fustat, sorely tried by the scarcity and dearness of food resulting from the bad Niles, groaned in secret over the caprices and severities of their ruler, but did not yet venture to express their dissatisfaction openly. It was otherwise with the free Arab tribes settled in the country, and in 395 the B. Qurra in Lower Egypt broke out in open rebellion. AlHakim had no great trouble in punishing these rebels but his severity in doing so, although it checked the movement, only left them ready to take up arms again on a more promising opportunity, and for this they had not long to wait.

A serious revolt took place in North Africa in 396, which before long seemed to threaten the very existence of the Fatimid Khalifate. In its first inception this revolt connected with far off Spain. There the Umayyads had been reigning since 138 , but were now in their decline. The supreme power at this time had passed into the hands of the Wazir Mansur ibn Abi 'Amir, who treated the Khalif of Cordova very much in the same way as Kafur had treated the later Ikhshids, but, more cruel and unscrupulous, was steadily getting rid of every one who stood in the way of his ambition. Many of the Umayyad kindred were put to death, whilst others left the country. Amongst these latter was one commonly known as Abu Raqwa, " the man with the leather bottle," because he carried a bottle like that used by the travelling darwishes. As a darwish he journeyed to Egypt, thence to Mecca, Yemen, and Syria, everywhere observing the possibilities of forming a party to support the claims of the Ummayyad family and the evidences of discontent and probabilities of 
stirring up civil strife. In all his wanderings, however, he met with no success: the Umayyads had long passed out of the main current of Islamic life, and it did not seem that their name could anywhere be used as a rallying cry for the dissatisfied; there was no religious attachment to the Umayyads like there was to the "Alids. At last he came back to Egypt at the time when the B. Qorra were smarting under the severe chastisement they had received from Hakim, and this seemed to him to offer some promise. Passing westwards he took refuge amongst the Berber tribe of Zanata where he obtained great esteem for his piety, acting as Imam in the services of the mosque and teaching the Qur'an to the children. It is perhaps as well to note that "Imam " in this connection means no more than customary leader in prayer; it has nothing in common with the "Imam " as understood by the Shi'ites, save that both imply the general idea of religious teacher. At length he managed to get a following, and proclaimed himself as Emir under the title of "he who is sent by the order of God" and " he who has victory over the enemies of God," both titles common enough amongst the Shi'ites but strange as applied to an Umayyad. His supporters were chiefly drawn from the Zanata, but before long he was joined also by other Berber tribes and by the B. Qorra.

At the head of a considerable army of the usual undisciplined Berber type Abu Raqwa advanced eastwards and took Barqa where he was careful to prevent all pillage and violence, and thus proclaimed that he was not a mere leader of tribes on the war path, but aimed at establishing an orderly government. At the fall of Barqa Hakim saw that the rebellion had to be taken seriously, and sent out an army under the command of Inal. This Egyptian force had to cross a considerable stretch of desert before it could reach Barqa, and Abu Raqwa sent a rapidly moving body of cavalry across the route to fill in the wells, and then waited at the end furthest from Egypt. At length Inal's force appeared, exhausted and thirsty from its desert march, and the engagement which followed left the advantage with $\mathrm{Abu}$ Raqwa. Before the action commenced a number of the Katama tribesmen serving with the Egyptians deserted and joined the enemy, induced to do so by 
disgust with the conduct and now notorious cruelties of Hakim. When they presented themselves before Abu Raqwa their first act was to intercede with him on behalf of their fellow tribesmen still serving in the Fatimid army, and as he promised them a favourable reception they called out to them and they deserted also. After this Abu Raqwa joined battle and inflicted a serious defeat on Inal. The news of this disaster caused great alarm in Cairo; there was an immediate rise in the prices of provisions, and preparations were made for another expedition to North Africa.

After his success Abu Raqwa made his residence at Barqa and seemed disposed to establish a kingdom in Ifrikiya. Before long, however, he received letters from several leading men in Egypt, including Husayn $b$. Jawhar who was Hakim's Commander-in-Chief, begging him to invade Egypt and assuring him of a welcome and substantial support. This, more than anything else, shows to what an extent the strange conduct of Hakim had now alienated his subjects and even those who, like Husayn, were his chief ministers and were, or had been, his personal friends. If we suppose that, by this time, Hakim had given unmistakable signs of disordered intellect we shall find in that a reasonable explanation of the desire for some one to come and deliver the country from what threatened to be a serious danger.

In response to this invitation Abu Raqwa started his advance into Egypt. The news of his undertaking threw the country into great alarm. The Druze books describe Hakim himself as completely unmoved, but other writers speak of him as seriously frightened and even planning to retire to Syria if all came to the worst. Meanwhile he sent to Syria for the Hamdanid armies, and put the general Fadl b. Salih in command of the native forces. With these Syrians and such other levies as he could raise Fadl went out and encamped at Gizeh, waiting for the invaders. At their arrival Fadl did not give battle, but manoeuvred so as to evade them, and by his position at Gizeh prevented them from being able to make a crossing of the river as that would have exposed them to his attack whilst going across. Meanwhile he managed to open up correspondence with some of the subordinate officers, amongst them with a 
certain captain of the B. Qorra named Mahdi, who agreed to keep him informed of all Abu Raqwa's plans. After some delay the invaders advanced direct upon the Fatimid general who was unable to evade the movement, and so an engagement was forced near Kum Sharik. It was not decisive, but it was very severe, and caused Fadl to determine not to give battle again if he could possibly avoid doing so. Owing to his severe losses he was compelled to retire, but still lay between Abu Raqwa and the river so as to be able to make a flank attack if the Berbers tried to cross.

Abu Raqwa and his men, however, were perfectly confident that success was assured, and made plans for their future policy as conquerors. They decided to settle in Egypt and rule that country and the adjacent North Africa, leaving Syria to the Arabs. This scheme repeated the old plan of a purely Berber state in Africa with the Arabs excluded and sent back to their own country. Fadl received full information as to these projects. But there was treachery in his own army also: the Arab leaders brought from Syria had been tampered with by Abu Raqwa's agents who tried to persuade them that they were making a mistake in fighting for the Fatimid state, and that it would be more satisfactory to divide its territories between them, the Africans under Abu Raqwa taking Egypt, the Asiatic Arabs taking Syria. It was agreed therefore that Abu Raqwa should make a night attack on Fadl's army and, as soon as the attack commenced, the Syrian leaders were to march their men over to the enemy and thus an easy victory would be assured. But Fadl was fully informed of this plan, and the evening before the projected attack he invited the Arab leaders to dine with him. When the dinner was over and the guests wished to retire he detained them and, on one pretext or another, kept them near him until the enemy attacked. Even then he still detained them and sent orders to the Syrians to engage their opponents, and the Syrians, ignorant of the private plans of their leaders, did so. The followers of Abu Raqwa were surprised at the unexpected resistance and were finally driven off.

Meanwhile Hakim succeeded in raising reinforcements of 4,000 horsemen, which he tried to send across the river to Fadl. Abu Raqwa heard of this and deter- 
mined to intercept them, setting out so quickly that Mahdi was unable to send a message to Fadl until he was already on the way. When the message reached Fadl it was too late, he could no longer get into a position to protect the new force from the fierce onset of the Berbers, and about a thousand of them were slain. The news of this misfortune, which Fadl contrived to conceal from his men for a time, caused great alarm in the city: the people were seized with panic, they feared an immediate assault, they were too much alarmed to remain in their houses and camped for the night in the streets.

Even yet the way to the river was not clear, for a considerable force remained ready to attack the Berbers if they tried to get down to the ford, and Abu Raqwa found it impossible to get to grips with them. So the Berbers were moved nearer and took up their position before the pyramids. Fadl followed at a distance. Then Abu Raqwa thought that he could force an engagement by leading him into an ambush. He passed on, therefore, towards the Fayyum, and at a place called Sabkha stationed a body of men in concealment and sent another company back towards Fadl. This body made a perfunctory attack and then turned to flight so as to draw the pursuers to the place of ambush. Unfortunately the whole plan had not been clearly explained to the men beforehand, and when those in ambush saw the others in flight they thought there had been a real defeat and, coming out of concealment, joined their retreat. "This change in the arranged programme threw Abu Raqwa's men into confusion, and Fadl profiting by the disorder fell upon them and inflicted a severe defeat. This took place on the 3 rd of Dhu 1-Hijja in 396. As a result Fadl was able to send to Cairo 6, ooo heads of enemy slain and Ioo prisoners.

This severe engagement was decisive, although Abu Raqwa himself escaped and fled, first to Upper Egypt, then to Nubia. Here he went to Hisnaljebel where the Nubian king lay ill, and pretended to be an ambassador sent by the Khalif Hakim. Owing to the king's illness he was not able to see him and thus, ostensibly waiting for an interview, he was able to live for some time in security. Fadl had followed close behind to the Nubian frontier and managed to find out where he was. As 
soon as he knew this he sent a messenger to the governor of the palace informing him of the facts, and the governor had Abu Raqwa kept under close observation. In due course the king died and his son ordered the fugitive to be conducted across the frontier, and so he was taken across and conducted to Fadl's camp. The Fatimid general received him with every courtesy and, fully supposing that Fadl's conduct represented the attitude of the Khalif the prisoner, as he was in spite of polite treatment, wrote a letter to al-Hakim appealing to his generosity and begging that he might be pardoned for his rebellion with protestations of penitence.

The letter was duly sent and Fadl marched down towards Cairo with his prisoner who was still treated with every consideration. Then they had passed Gizeh and were about to enter Fustat, on Saturday the 27 th Jumada II. 397, orders were received by Fadl from the Khalif that Abu Raqwa was to enter the city riding on a camel, wearing Abzari's turban, and with Abzari and his monkey mounted behind. Abzari's turban was one of many gaudy colours which it was customary for those condemned to death to wear on their final parade to the place of execution, and the monkey was specially trained to strike with a whip across the face of a criminal set in front of him. For this performance Abzari was to receive 500 pieces of gold and ten pieces of cloth.

Thus Abu Raqwa entered Fustat in the midst of the army, preceded by fifteen elephants. The whole city was adorned as for a public holiday, and the population lined the streets to see Abu Raqwa paraded until he was brought to a balcony where al-Hakim was seated. The Khalif then pronounced on him the sentence that he was to be conducted to a piece of elevated ground before the mosque of Raydan and there beheaded. But when they reached the place of execution and the camel knelt for Abu Raqwa to dismount it was found that he was already dead. The body was stretched out, and the head cut off and carried to the Khalif.

This success raised Fadl's reputation, and for a time al-Hakim showed great appreciation of his services. Then the general fell ill the Khalif visited him several times, and when he recovered he presented him with 
gifts of large estates. Two years later, however, Fadl was put to death.

Severus of Ashmunayn relates an anecdote about alHakim which is commonly supposed to refer to Fadl, but it is not certain that it does so refer, and many things related by Severus seem to be open to question. According to this anecdote a certain favourite, who may have been Fadl or may not, once entered al-Hakim's presence and found him with a comely child whom he had bought for Ioo pieces of gold. He had just cut the child's throat, and had opened the body and taken out the liver and entrails which he was cutting up as the visitor entered. At the sight the onlooker could not repress an involuntary movement of repulsion and hastily withdrew. He knew quite well that his discovery and expression of disapproval meant his execution, and at once went home, put his affairs in order, and waited for his summons. Before long a messenger from the palace arrived, and the minister who had seen too much was led away and put to death. Whether Fadl was the hero of this anecdote, or whether the story has any basis at all, remains uncertain, but it is known that he was executed by the Khalif's orders.

Abu Raqwa's rebellion certainly makes an important turning-point in Hakim's reign. After it he made certain concessions to prevailing Muslim opinion, that is to say he relaxed some of his Shi'ite prejudices and left off some of the practices, such as the cursing of the early Khalifs, which were most offensive to his orthodox subjects, but at the same time he increased in severity towards the Christians and Jews who were generally hated as forming the greater part of the civil officials and tax-collectors.

As might be expected the rebellion was followed by several changes in the personnel of the court. The Commander-in-Chief, Husayn b. Jawhar, was deprived of his office on the Ioth of Shaban 398, ordered to remain in his house, and forbidden to take part in the public processions which accompanied the Khalif on his visits to the principal mosques: but shortly afterwards he was pardoned and ordered to resume his place in these functions. As we have seen, it was Husayn who took part in the invitation to Abu Raqwa. Whether this was known at the time to the Khalif or 
not does not appear, but it is very probable that he had reasons for suspecting his fidelity. The office of Commander-in-Chief was given to Salih Rudbari b. Ali.

On the I6th of Rejeb 398 the Chief Qadi and Da'i 'Abdu 1-'Aziz also was deprived of office, perhaps here again there was reason to suspect correspondence with the enemy, and his place given to Malik b. Sa'id alFaraqi. About three years later, as we shall see, both Husayn and 'Abdu 1-'Aziz were so much alarmed that they fled the country, but afterwards returned and were put to death in 40I. A change was made also in the important governorship of Damascus to which 'Ali b. Falah was appointed in 398 .

We may trace a connection between the anxiety caused by Abu Raqwa's revolt, complicated by growing dissatisfaction amongst the people, with Hakim's abandonment of his more aggressive Shi'ite attitude and partial return to Sunni practice. In 397 he ordered all the inscriptions reviling the early Khalifs to be effaced, and all persons who cursed them were punished by flogging and paraded through the streets in disgrace (Maq ii. 286, Ibn Khall. iii. 450). This year (397) he sent a white veil to cover the "House of God" at Mecca, white being more or less the official colour of the Fatimids. Perhaps this more orthodox attitude should be connected with his severer treatment of the Christians which dates from 398, and both were bids for popularity.

The year 398 had a particularly bad Nile, the river rising only sixteen yards and sixteen fingers of the seventeenth yard, with the result that there was a great rise in prices and consequent hardship. Complaint was made to the Khalif that the dearness of corn was largely caused by dealers hoarding supplies so as to force an increase, and al-IIakim announced that he would ride through the city himself and make enquiry, and would behead anyone he found with a hoard of corn. Next day he rode from his palace and passed through Fustat and out to the mosque of Rashida, his attendants entering houses and searching for stores of corn. None, however, were found, and the result of this was that popular feeling was pacified and the idea that the scarcity was artificially produced removed. In 399 the 
Nile suffered an unexpected check and there was increased anxiety. Twice the Khalif conducted public prayers for a good Nile. Several taxes were remitted, but bread became so dear that it could be obtained only with the greatest difficulty. On the $4^{\text {th }}$ of the Egyptian month of Tot (circ. Ist September) the canal was opened, but the river had then risen only 15 yards. On the $9^{\text {th }}$ of Muharram, the middle of Tot, the waters began to go down, the total rise having reached only 16 yards : as a result food became even dearer and the famine was followed by plague.

It was no doubt as an act of mourning that Hakim issued orders forbidding the holding of pleasure parties, excursions, or concerts on the river or its banks.

Although al-Hakim, by ordering the removal of the imprecatory inscriptions against the early Khalifs had done something to conciliate public opinion, he continued to enforce strictly the regulations against wine, beer, and the various kinds of food disapproved by the Shi'ites, and many fishmongers were arrested for selling fish without scales. Indeed the city was thrown into consternation by the extreme severity with which these and other rules were enforced. It was in this year (399) that the general Fadl was executed, and many other persons were punished by having their hands cut off. A decree published this year allowed the fast of the month of Ramadan to finish at the date as obtained by astronomical calculations, without waiting for the actual appearance of the new moon, a Fatimid novelty which was regarded with disapproval and is still not admitted by the orthodox. New regulations allowed the use of the Shi'ite formula in the call to prayer, or the Sunni call at the muezzin's discretion; no complaint was to be made in either case. No one was to utter any imprecation against the early Khalifs, and if any one liked to use the reverent formula "God have mercy on them " in using their names, thus treating them as saints, they were allowed to do so: if on the other hand they chose to use the more honourable formula "God be gracious to him " after the name of " $\mathrm{Ali}$, there was full liberty to do so. Every Muslim was free to follow Sunni or Shi'ite usage as he preferred (Ibn Khall. iii. $45 \mathrm{I})$.

Al-Hakin's more definite anti-Christian and anti- 
Jewish policy began in 398 . In that year he seized the property of the churches and placed it under the control of the state treasury. He forbade the public processions which had generally been observed at the feast of Hosannas (Palm Sunday), at the feast of the Cross, and at the Epiphany. By his orders a large number of crosses were publicly burned before the doors of the Old Mosque, and orders were sent out that the same was to be done in the provinces. In some of the churches little mosques were constructed, and from these the usual call to prayer was given. Severus tells us that the use of bells was now prohibited.

The churches on the road to Maqs were destroyed, as well as the Coptic church of al-Maghitha in the Street of Rome, and all their contents were seized. Many other churches were pillaged and destroyed, the sacred vessels, furniture, and goods being handed over to Muslims, and the vessels often sold in the public markets. Amongst these were the churches at Rashida outside Fustat and the convent of Dayr al-Kasr on Mokattam, all these being given over to the people who plundered them.

Various persons sent in petitions to search churches and monasteries in the provinces for hoarded wealth, and received permission to do so (cf. Maq. Hist. of Copts). It is clear that this kind of persecution was generally popular, at least in its earlier stages, for it was generally believed that the Christians had used their opportunities as tax collectors to defraud the country to a serious extent. This no doubt contained a measure of truth, although the Fatimid government kept a closer and more careful control over its officials than has always been done by oriental powers. But it must be noted that resentment was felt towards the Christians and Jews, not for their religious beliefs, but because they were revenue officials.

In 400 Salih b. "Ali Rudbari was deprived of his office as chief minister and replaced by Mansur $b$. 'Abdun, a Christian clerk, for at no time did the persecution take such a form as to prevent the advancement of Christians and Jews to high and responsible offices in the state. The new minister was hated by the nobles who made accusations against him and brought forward 
his religion as one of the grounds of attack. This caused a brief but severe outburst against the Christian officials. Many of them were scourged to death and their bodies thrown to the dogs, and Mansur himself was beaten and left for dead, but as his friends stood round they perceived that there were signs of life in him, so they took him up and carried him home. After some time he recovered and went back without remark to his duties. Such a state of affairs seems to us almost incredible, for his duties were practically those of a prime minister, and that he should have been thus scourged, left to the dogs, as was the intention, and then when he was well enough go back to the highest office in the state without any particular remark seems to present al-Hakim's court rather in the light of $d$ lunatic asylum : practically it was very near that, for it can hardly be doubted that the Khalif at this time was definitely insane.

Orders were sent to Jerusalem for the destruction of the church of al-Qayama " the resurrection," the most famous and honoured sanctuary of Christendom. In accordance with these orders it was plundered and then pulled down, an act which produced a deep feeling of anger in the Christian community generally, as well as amongst the subjects of the Greek Empire as amongst those who lived in Hakim's dominions. Indirectly it caused the Christian world to form an idea of Islam as a persecuting power, and so paved the way to the Crusades. The cause of the destruction of this sanctuary is said to have been a malicious report which alleged that the Christians practised a fraud in connection with the "holy fire" given out at Easter in that church. This blessing and distribution of new fire is a prominent part of the Easter Eve ceremonies of the Greek and of the Gallic churches, and from the latter afterwards passed into the Roman rite where it originally had no place. A common but apparently unauthorised superstition amongst the Greeks represents this " new fire" as distributed in the Church of the Resurrection at Jerusalem as sent down from heaven, and this superstition was already in existence in the davs of Hakim. A certain chaplain of the church, suffering from some grievance, declared to the Muslim authorities that the canons of the church prac- 
tised a fraud to play upon this superstition. He said that they used to anoint the iron chain by which the great lamp was suspended in the chapel of the Holy Sepulchre, and that after the Muslim governor had closed and sealed the door of the church, as was the custom, they used to get at the chain from the roof and so the fire was passed along the anointed surface and reached the wick of the lamp which was thus lighted, whilst the chaplains sang Kyrie eleison and wept, and pretended that the fire came down from heaven, thus confirming the Christians in their religious errors (Bar Hebraeus: Chron., pp. 2 I 5 sqq.).

Severus attributes the outbreak of this persecution to a monk named John whom the Patriarch steadily refused to ordain bishop and who, on this account, made his complaint to the Khalif. He waylaid Hakim as he was walking on the Mokattam hills and called on him for assistance, at the same time presenting a vetition in which he said: "You are the ruler of this country, but the Christians have a king who is more powerful than you by reason of the immense wealth he has acquired. He sells bishoprics for money and acts in a way displeasing to God." Influenced by this petition Hakim ordered the churches to be closed and the Patriarch to be brought before him. The Patriarch Zacharias was a man far advanced in years and now, by the Khalif's order, was cast into prison. The very day after the Patriarch's arrest Hakim sent the letter to the governor in Jerusalem ordering the destruction of the Church of the Resurrection, the clerk who prepared the letter being a Christian named Ibn Sharkin.

Shortly after this Hakim sent out notices to all the provinces that churches were to be destroyed and their gold and silver vessels confiscated, that all bishops were to be arrested, and that no one was to buy from or sell to Christians. At this many Christians conformed to Islam, whilst in most places they left off the distinctive outward signs of their religion as laid down in the revived penal laws, and popular usage evidently connived at this.

The Patriarch remained three months in prison; each day he was threatened with burning or being cast to wild beasts if he did not conform to Islam, whilst he was promised that if he did conform he would be made 
Chief Qadi and covered with honours, but neither threat nor promises made any impression on him. His gaoler visited him frequently and treated him roughly, but this he bore with patience and resignation. A Muslim fellow-prisoner tried to persuade him to conform, but he only replied, "All my confidence is in God who is almighty; it is He who will help me", (Severus).

A certain Christian who had been collector of taxes was in the same prison suffering the penalty for a deficit of 3,000 pieces of gold in his accounts. This prisoner was a friend of a noble Arab of the B. Qorra tribe, named Mahdi b. Mokrab, perhaps the same who had assisted Fadl at the time of Abu Raqwa's revolt, and he stood high in the Khalif's favour. One day he visited his Christian friend and promised to ask the Khalif for his release. The prisoner said, "I should not be willing to go out of this and leave here the Patriarch, the old man whom you see." Mahdi enquired why the Patriarch was in prison, and when he heard the reason he judged that it would not be prudent to speak about him by name to Hakim, but he asked the Khalif to grant the liberty of all those who were detained in that prison. The Khalif consented and so the Patriarch was set free and went to Fustat, a thing which was the cause of great joy to all the Christians. But as his freedom had been granted only by an oversight it was judged expedient for him to go away and hide himself, so he retired to the valley of Habib where he lived in retirement for nine years. In that particular part the churches had not been destroyed. Officials and workmen had been sent to do so, but they were afraid of the Bedwin of the desert near and retired without doing anything.

The Khalif issued orders forbidding the Christians to observe the " Feast of Baptism," i.e., the Epiphany, on the banks of the Nile, and prohibited the games and amusements which usually accompanied the celebration of that feast. He also forbade the observance of the "Feast of Hosannas," i.e., Palm Sunday, and the Feast of the Cross in the autumn. At that time it was customary for Muslims and even the Khalifs themselves, to take part in the public festivities with which the Christians celebrated their greater festivals. 
The destruction of churches was general during the course of this persecution, especially in the year 403 . By 405 some 30,000 had been pillaged and pulled down in Syria and Egypt, and many of the Jewish synagogues were treated in a similar manner. Very often mosques were erected on their sites. The great church of the Mu'allaqa was taken from the Christians, and the Muslim call to prayer was made in the Church of Shenuda in Fustat. In many places people presented petitions asking permission to seize one of the churches or monasteries, and these petitions were invariably granted. The furniture of the churches and their vessels of gold and silver were confiscated and sold in the markets, the price obtained being paid into the treasury or given to some of the Khalif's retainers. A special board was established to deal with the confiscated property and the goods belonging to those who had been put to death.

We turn now to Hakim's dealings with the Muslims during the year 400 . In the earlier part of the year many persons who had been detected in possession of beer, malukhia, etc., were arrested and beaten. There was a growing disquiet at Hakim's severity, and a large number of people thought it well to take out letters of protection. Panic seized Husayn b. Jawhar the exCommander in Chief, 'Abdu 1-'Aziz b. Nu'man, and Abu 1-Kasam Husayn b. Maghrabi, and they fled the country. The laws against intoxicating drinks were executed with great rigour, and a number of eunuchs, clerks, and footmen were put to death. In the month of Shawal Salih b. 'Ali Rudhari was put to death. On the igth of this same month an order was published dispensing with the payment of the fifth levied on the Shi'ites, of the sum paid at the end of Ramadan as alms, and of the nejw'a, or "voluntary contribution," all sums collected from the Isma'ilian sect. About the same time the "conferences of wisdom," the regular meetings of the sect which were held in the palace, were discontinued. This seems like an anti-Shi'ite change of attitude on the Khalif's part, but the only reasonable explanation of the numerous and arbitrary developments which took place about this time is that which commended itself to many contemporary ob- 
servers, namely, that the Khalif was insane, and the disorder of his mind was growing worse.

Later in the year Hakim abandoned the enforcement of several distinctively Shi'ite usages. He ordered the restoration of the formula known as the tethwih in the call to prayer; the muezzins were forbidden to add "Come to the most excellent work" to the call, and were ordered party badges. Permission was given for the use of the salat ad-Duha or voluntary forenoon prayer which had been strictly forbidden in 393, and also for the use of the prayer known as kunut. In the course of the year Hakim presented lamps and a large candelabrum to the Mosque of Rashida.

The result of these events was that Hakim fell into ill repute with the Shi'ites who had come to Cairo from many parts, and now found themselves in a town veering round to orthodox Muslim customs. Other events, however, quickly made him even more obnoxious to the orthodox. He had sent officials to Madina to open the house which had formerly belonged to Ja'far as-Sadiq and to bring away whatever might be found there. When the house was opened the officials found in it a Qur'an, a bed, and some furniture, and the $D a^{\prime} i$ Khatkin, who superintended the opening, carried away these articles, and at the same time helped themselves to the taxes which the sharifs paid. Khatkin then returned to Egypt accompanied by a large number of sharifs, all descendants of 'Ali, who were led to expect generous treatment from Hakim. But when they reached the Khalif's presence he gave them only a very small part of the money Khatkin had brought back and kept the bulk for himself, saying that he deserved it more than they did, as he, the true heir of 'Ali, was the head of the sharifs. The sharifs at this left Cairo and returned to Madina cursing him (Abu 1-Mahasin).

Hakim then decided to remove the bodies of the two first Khalifs, Abu Bakr and Umar, who were buried at Madina. His envoys bribed an 'Alid who lived in a house close by the burial place, and with his help they began digging a passage through to the tombs. But a violent storm arose which so terrified the citizens that many of them sought refuge in the holy place where the Prophet and the early Khalifs were buried. The 
storm still continued until at last the 'Alid who had assisted Hakim's envoys himself became alarmed, and revealed the project on which they were engaged to the governor who had him punished, and provided that the plan should not be carried out (Mirkhond on the authority of the Istidkar of the Qadi Ahmad Damagini).

On the whole Hakim seems at this time to have been endeavouring to conciliate Sunni opinion, perhaps he had even intended to honour Abu Bakr and 'Umar by shrines in one or other of the burial places of Cairo. Certainly he was trying to please the Sunnis when, in this same year (400), he founded a college for instruction in the Malikite system of jurisprudence, the form of canon law in vogue before the arrival of the Fatimids, and the one to which the Egyptians were most attached. He presented the college with a library, and appointed Abu Bakr Antaki as its principal, and bestowed robes of honour on the principal and the lecturers whom he welcomed at court. For three years Hakim continued to favour the Sunnis, and then he suddenly changed his attitude. In the following year indeed the pro-Sunni decrees began to be modified. On the I2th of Rabi" II. 40I the call to prayer was again ordered to be made in the Shi'ite form, the tethwib, and the words "Prayer is better than sleep" were again forbidden, and the formula " Come to the excellent work" was restored. The fore-noon voluntary praver was prohibited and so the Tarawih. When Hakim found that the latter form had been used in the Old Mosque in spite of his prohibition during the whole of Ramadan he had the leader of the prayer put to death. At the same time the "Conferences of wisdom" were restored in the palace, and the various subscriptions due from the initiated of the Isma'ilian sect were again collected. It is impossible to follow anything like policy or purpose in these incessant changes; it can only be supposed that the Khalif's mental malady was getting worse.

In the following year (4OI) new laws were published forbidding all pleasure parties on the banks of the canal and requiring all doors and windows opening on the canal to be kept closed: other laws forbade music, games, or meetings for pleasure at Sahra: and others 
forbidding loose entertainments anywhere or the sale of singing girls.

Changes in the personnel of the administration now begin to become more numerous and capricious. At the beginning of 401 the chief minister, Mansur $b$. Abdun, the one who had once been scourged and left for dead, was deprived of his office, and later in the year was put to death and his goods confiscated. $\mathrm{He}$ was replaced by Ahmad b. Muhammad Kashuri, who was beheaded after ten days. The next minister was the clerk Zara, son of Isa b. Nestorius. Husayn b. Jawhar and 'Abdu 1-'Aziz b. Numan, who had fled the country in the previous year were invited to return and were received with honour; only to be put to death and have their goods confiscated a few months later. The third fugitive, Abu 1-Kasam Husayn, had gone to Syria and declined to come back. IVe shall find him a little later stirring up trouble for Hakim.

Turning to Syrian affairs we find similar rapid and frequent changes. In $400 \mathrm{Abu}$ 1-Jaysh Hamid b. Masham was replaced by Muhammad b. Nazae as governor of Damascus. In for Lu'lu' b. Abdullah was appointed governor, reaching Damascus in the month of Jumada II. On the Ioth of Dhu 1-Hijja at the "Feast of Sacrifice" he was replaced by Dhu 1-Karnayn.

The most important event of for was the revolt of Hasan b. Mufarraj b. Daghfal b. Jarrah Taiy (cf. year 387 ). He was persuaded to this by Husayn, the one of the three who fled from Egypt in 399 and was not willing to return. His two sons and two brothers had been put to death at the request of the minister, Mansur b. Abdun, his mortal enemy, and it was this which had alarmed him and caused his flight in the first place. He took refuge with Hasan, and used every persuasion to induce him to revolt. The rebel faction was headed by Hasan's father Mufarraj, and was joined by a number of Arabs, and very soon by the whole of the tribes of the Hijaz under the leadership of the Sultan of Mecca, Husayn b. Ja'far. Hakim sent Yarakhtakin to Aleppo with a large army to put down this movement. As soon as he arrived in Syria Mufarraj and his son became extremely anxious but, between Gaza and Ascalon they managed to get him into an ambush, and 
in the ensuing battle the Fatimid general was slain. The rebels then besieged Ramla and, as new recruits pressed in every day, they soon took it. Hakim sent them letters of remonstrance, but these were disregarded, and they invited the Sultan of Mecca to assume the Khalifate. This he was perfectly ready to do and, leaving a deputy in the city, joined the army of Mufarraj, and was saluted "Commander of the Faithful.',

But Hakim wrote again to Hasan and Mufarraj promising them estates and other gifts if they would cease from rebellion, so they resolved to abandon the newiy proclaimed Khalif and returned to their allegiance. The result of this was a violent dispute between them and the man they had just invited to be Khalif. In the end he left them and returned to Mecca, taking Husayn Maghrabi with him. Not long afterwards Hakim sent an army under Ja'far b. Fallah to Syria, and expelled Hasan and his followers from Ramla. For two years Hasan remained in exile then, at the intercession of his father Mufarraj, Hakim pardoned him and gave him an estate in Egypt. Ultimately Mufarraj was poisoned by the Khalif's orders. The anti-Khalifate of Mecca continued until 403, when the prince requested to be reconciled to Hakim, and when this was granted put Hakim's name on his coinage and inserted it in the khutba.

In 40I Karwash b. Mukallad, chief of the Arabs of Okayl, revolted against the 'Abbasid Khalif and transferred his allegiance to Hakim. whose name was inserted in the khutba in Mosul, Anbar, Madayn, and other towns. In Mosul the form commenced: "Praise be to God, by whose light the shadows of tyranny have been scattered, by whose greatness the foundations of the heresy of the enemies of ' $\mathrm{Ali}$ have been rooted up, by whose power the sun of truth has risen in the west (i.e., in Africa)." Baha d-Dawla, the 'Abbasid Khalif's guardian, ordered the Emir al-Joyush to march against Karwash, who at once sent his apologies to the Khalif of Baghdad, and the recognition of the rival Fatimid Khalif ceased.

Next year (402) Hakim made more rigorous decrees against beer, vegetables disapproved by the Shi'ites, and the use of fish without scales. He further forbade 
women to go to funerals or to visit the cemeteries. He strictly suppressed the playing of chess, and caused chess-boards to be burned. Gathering the fishermen together he exacted from them a pledge that they would not take any fish without scales, and further threatened them with death if they were found selling any such.

He had already forbidden the use of beer, and the usual law against wine was strictly enforced. Now he forbade the sale of dried raisins because they were used by some for the making of wine: he forbade their importation into the country, and ordered all found in stores to be destroyed, in consequence of which some 2,340 boxes of dried raisins were burned, the value being put at 500 pieces of gold. He next forbade the sale of fresh grapes exceeding four pounds at a time; in anv case grapes were not to be exposed for sale in the markets, and strict prohibition was made against squeezing out the juice. Very many grapes found on sale were confiscated, and either trodden in the street or thrown into the Nile. The vines at Gizeh were cut down and oxen employed to tread the fruit into the mire. Orders were issued that the same was to be done throughout the provinces. But honey as well as grapes can be used in preparing fermented liquor, so the Khalif's seal was affixed to the stores of honey at Gizeh, and some 5,05I jars of honey were broken and their contents poured into the Nile, as well as $5^{\mathrm{I}}$ cruises of date honey. The sale of fresh dates was then forbidden, and many dates were collected and burned (Maq. ii. 287, Ibn Khall. iii. 450).

A curious story is told by Severus of Ashmunayn in connection with these laws of 402. A certain merchant had all his money invested in the prohibited fruit, and lost everything by the seizure and destruction of his goods. He appeared before the Qadi and summoned Hakim to appear and make good the destruction caused by his officials. The Khalif appeared to answer the charge preferred against him, the Qadi treating him like any other citizen against whom complaint had been made. The merchant asked for compensation to the amount of $\mathrm{I}, \mathrm{ooo}$ pieces of gold. Hakim in his defence says that the fruits destroyed were intended to be used in the preparation of drinks forbidden by the law of the Qur'an, but that if the merchant will swear that 
they were not intended for this purpose but only to be eaten he was willing to pay their price. The merchant refuses to take the oath until the Khalif actually produced the money before the Qadi. Hakim ordered the money to be brought into court, and when it is produced the merchant swore that the fruit was intended only for eating. He then received the money and gave the Khalif a formal receipt. He then demanded letters of protection from the Khalif that he might not incur any retaliation for his suit, and these were given. When the case was concluded the Qadi, who had up to this point treated both parties as ordinary suitors, rose from his seat and gave the Khalif the salute customary at court. Hakim admired the Qadi's conduct, and made him valuable presents in recognition of his treatment of the case.

This year the 'Abbasid Khalif assembled the leading 'Alids and several prominent canonists at Baghdad, and prepared a manifesto against the 'Alid claims of the Fatimid Khalifs. To this we have already referred (cf. p. 48 supra): how much weight should be attached to it is doubtful, for the motives and pressure brought to bear are obvious. We know, however, that Hakim was greatly annoyed by it.

We have come now to the year 403, another bad year of great scarcity and famine. Early in the year (on the 2nd of Rabi' I) the minister, Zara b. Isa b. Nestorius, was put to death and his place given, twentyseven days later, to Husayn b. Taher al-il azzan, who received the title of Emir al-Umara " Prince of the empire." This Husayn began to make a careful survey of the income and expenditure of the state, and expressed his plain opinion that Hakim's constant and lavish presents were unwise, some measure of economy was urgently called for. It seems that these acts of generosity had now become excessive. In after years the sacred books of the Druses in praising Hakim lay especial emphasis on his unexampled generosity in presenting not only honours and titles but also pensions, estates, fiefs, etc. upon all his friends (cf. de Sacy: Chrestom. ii. 69-7o). The Emir even suspended payment of the orders brought to the treasury bearing the Khalif's seal, and addressed a remonstrance to the sovereign. Hakim replied in a tune of kindly remon- 
strance urging the treasurer to pay the orders. The Emir did so, but sends in a full statement of the sums paid and of the gifts made to strangers.

Extravagance was the besetting fault of all the Fatimids, but it reached its extreme in Hakim. Whilst he was alienating large portions of the public property which was not, of course, distinguished from his own private possessions, he was also making lavish gifts to the mosques of Fustat and Cairo. In Jumada II. of this year he resolved to furnish the mosque which he had completed in Cairo and which bears the name of Hakim's Mosque. A preliminary estimate of the cost of the lamps, chains, mats, etc. came to 5,00o pieces of gold. Early in Ramadan he presented a tannur or large candelabrum to the Old Mosque in Fustat. This tannur weighed I00,000 drams and had I,200 lights. It was carried to the mosque to the sound of drums and trumpets and with cries of tehlil (" there is no power or might but in God ") and takbir ("God is great "), the procession being led by the Ka'id (Commander-inChief). When they came near the mosque it was found necessary to remove the mastabas or stone benches outside the houses on the way, and to dig up the roads to enable the tannur to be brought to the door, and then the upper part of the door had to be removed by masons to get the lamp in. The Khalif presented the mosque at the same time with 1,290 copies of the Qur'an, some of which were written in letters of gold.

At the beginning of his reign Hakim had forbidden the use of the honorific titles customarily applied to the Fatimid Khalifs. He now forbade the custom of kissing the ground before him, and of kissing his hand or stirrup. These customs, he stated, were imitated from the Byzantine court and so not seemly for Muslims. In salutation he desired the use of the simple formula : "Hail to the Commander of the faithful; may the mercy and blessing of God be on him.' Never in speech or in writing might the formula be used, " God be propitious to him," as this was applied to the patriarchs and saints. In writing petitions, etc., the formula should be, " May the peace of God, his abundant favour and blessing, rest upon the Commander of the faithful." Similar forms, and no others, were to be used in praying for the Khalif: in the 
khutba the form approved was, "O God, be propitious to Muhammad thy chosen; grant peace to 'Ali the first of believers, whom thou hast honoured with thy bounty: $O$ God grant peace to the princes of the believers, the fathers of the Commander of the faithful : $\mathrm{O}$ God, may thy most excellent peace rest on thy servant and vicar" (Maq. ii. 288, Ibn Khall. iii. 45I).

At the palace the use of cymbals and trumpets when the guard made the rounds was forbidden, all was to be done without music. A new seal was engraved for the use of the Khalif bearing the inscription, "By the help of God most high and beneficent, the Imam 'Ali will be victorious" (Maq. id.).

Various events of passing interest are associated with the month of Jumada II. of this year, the month, it will be remembered, in which the Emir of Mecca abandoned his claim to the $\mathrm{K}$ halifate and was reconciled to Hakim. On the very day on which the Emir's envoy was received Hakim commenced building an observatory at Karafa. This observatory was never finished. It should be noted in passing that various occasional references in the historians justify us in regarding Hakim as greatly interested in astrology as well as in other branches of natural science, and in this he was true to the Fatimid tradition. After receiving the submission of the Emir of Mecca Hakim wrote a letter to the Sultan, Mahmud of Ghazna, the great champion of orthodoxy, asking for his allegiance. It could hardly be expected that Mahmud would tolerate or recognise any Shi'ite, least of all the head of the Fatimid dy nasty. On receiving the letter the Sultan tore it in pieces and spat on the fragments, afterwards sending them to the 'Abbasid Khalif al-Qadir.

It was perhaps in this year, as De Sacy thinks, although Abu 1-Mahsin refers to 400, the Tarikh Jafari to 404 , that a crowd of men, presumably Shi'ites, came to the palace demanding justice against the Egyptians. It seems that, as Hakim was now passing through an orthodox phase and, as we have seen, had abandoned some of his pro-Shi'ite legislation, the orthodox Egyptians had been teasing the Shi'ites and paying them back for the insults they had ventured upon in the time of their ascendancy. They were not able to obtain an interview with the Khalif, but were told to come 
again next day. Some go away, but many pass the whole night before the palce. Next day the clamours recommenced, until at length the Ka'id appeared and ordered them to withdraw. They then went to the Qadi who assured them that he had no power of dealing with their complaints, and they left his court cursing the " Companions," that is to say, the early Khalifs who, though regarded by the Shi'ites as usurpers and enemies of 'Ali, were admittedly companions of the Prophet (Maq. ii. 288).

This was followed by an order strictly forbidding any persons to curse the "Companions," and before long several persons were punished for this offence. One day Hakim saw such curses written up on a public inn, no doubt so written at the time when he had commanderl the putting up of inscriptions of this sort. These he ordered to be effaced and sent officials through the streets reading out an order that all such inscriptions on inns, shops, streets, etc. must be removed, and great care was taken to see that the order was carried out. All this was a bid for popularity with the orthodox, and this year he made a further bid by assigning property for the support of the indigent, and for the doctors in the various mosques and the muezzins.

It was in Ramadan of 403 that Hakim showed the zenith of his passing orthodexy. Each Friday duriny this month he attended the Mosque of Rashida clad simply, with a turban without jewel and having a sword adorned only with bands of silver, and himself led the public prayers. During his progress to and from the mosque any person who desired to do so was free to approach him, and he took the memoranda and petitions which they presented him, conversing with the petitioners. On Friday the ioth he did thus, clothed plainly in a garment of white wool and riding to the mosque on an ass. On the 27 th of Ramadan he went to the Old Mosque and made there the khutba and led the Friday prayer, a thing which no Fatimid had done before. This visit was made without any display; there was no cortège or led horses, save only ten horses whose saddles and bridles were plainly adorned with silver; over his head was borne a plain white parasol without the usual gold fringe; there was no jewel in his turban, and the pulpit in the mosque was without 
hangings. The same simplicity was observed at the Feast of Sacritice, at which the victims were slain by the heir, 'Abdu r-Rahim (Maq. ii. 288). The ceremonial thus cibserved at the close of Ramadan was to a large extent of Shi'ite origin, but it was a concession to the feeings of the people that the Old Mosque was used. It will be remembered that it was during this month that Hakim presented the great tannur to the same mosque.

The persecution of Christians and Jews continued, and even became more severe, during this year (404). The order that Christians should wear black robes and turbans was renewed; they had to bear crosses of wood a yard long and a yard wide, and to carry them so that they could be seen. This was done to many Christians wearing small crosses as ornaments, and often carrying them beneath the outer garment. Jews received similar orders as to the billets of wood which served as their distunctive badge. According to Severus both cross and billet had to be marked with a lead seal bearing the Khalif's name: this no doubt means that those of the proper size and material received this seal as a mark that they were approved. Both Christians and Jews were forbidden to ride horses; the mules and asses which they used must have plain saddles of wood and stirrups of sycamore wood without any ornament. Neither were allowed to have Muslim servants or to buy a slave of either sex. Muslim owners of riding animals were forbidden to let on hire to Christians or Jews, and Muslim sailors similarly were forbidden to take them in their boats. Both Christians and Jews were forbidden to wear rings on their right hand. All these orders were proclaimed in the streets of Fustat and Kahira, and great pains were taken to see that they were rigorously enforced. Many Christians turned Muslim in order to avoid these vexations (Maq. loc cit.).

It is not easy to date precisely all the anti-Christian and anti-Jewish legislation. It is certain that it commenced in 393 and came to an end in 405, that for the most part it increased in severity up to 403 , and then slightly relaxed, but there are various divergences of detail in the accounts as to the actual orders enforced in each of the intervening years.

De Sacy thinks that it was about this time (404) that 
the conference of the Christians and Jews with Hakim to which reference is made in the books of the Druses, took place. One day as the Khalif was walking at Karafa, in the cemetery Kibab attair, a band of representatives of the two persecuted religions waited upon him. He permitted them to speak with him and assured them that they might talk freely without fear. They pointed out to him that his conduct towards them was very different from that of the Prophet and of his early successors; they asked how he could justify his policy which was so opposed to the compacts which had been made with them. Hakim asked them to retire and meet him again in the same place the following night, to bring their learned men with them, and assured them again of his protection under which they might speak freely. Next night Hakim relates to them the conferences which the Prophet had with Christians and Jews in his day, conferences which were designed to bring about their conversion but which failed in this result; for four hundred years Islam has been available, and the reasons brought forward by the Prophet had been under consideration : now you are offered the choice of Islam again after all this delay, if you do not now accept the punishment can be no longer postponed. The representatives admit the truth of this and retire from Hakim's presence. It is very doubtful, however, whether we can regard this description as given in the sacred books of the Druses as in any way belonging to serious history.

The Khalif this year gave permission to the Christians who wished to do so to emigrate to the land of the Greeks, or to Nubia, or Abyssinia, permission which had previously not been conceded, and many did thus emigrate. De Sacy connects the incident which we have related above with this permission to emigrate.

Although Hakim had been, and still continued. devoted to the study of astrology, he now made a decree against the astrologers who are to be banished. Many of these astrologers went to the Qadi and entered into a solemn undertaking not to practise their art, and on the strength of this promise were allowed to remain. Maqrizi notes it as a strange thing that after this decree one could no longer see astrologers in the streets. Perquisition was made and any of these found were 
brought before the Qadi and expelled from the country. The same treatment was meted out to professional musicians (Maq. ii. 288, Ibn Khall. iii. 450).

A general report began to circulate in the course of this year that Hakim intended to have a great massacre of many people, and the report, though vague, was readily believed, with the result that multitudes fled from Cairo, so that the markets were suspended and all business came to an end for the time (Maq. ii. 288).

On the I2th of Rabi' I. 'Abdu r-Rahim, who had killed the victims at the preceding Feast of Sacrifice and was a great grandson of the Mlahdi who had been the first Fatimid Khalif, was publicly declared heir to the throne to the exclusion of the Khalif's infant son. Orders were given that he was to be saluted in the form : "Hail to the cousin of the Commander of the faithful, the designated successor of the sovereign of the Muslims." His name was placed on the coinage, he received apartments in the royal palace, his name was inserted in the khutba, and he acted as the Khalif's deputy in all business of state. Business was at this time little regarded by Hakim, who spent much of his time riding about in the city and in the country round, sometimes by day, often also by night.

In the following month he cut off the hands of the Ka'id's secretary, Abu 1-Kasim Jarjarai. This secretary had been in the service of the Princess Hakim's sister, but fearing that this was a dangerous place had left her for the service of the Ka'id. The Princess desired to know the reason of this change, and the secretary sent her a letter in which he made reference to a certain matter which he had discovered,-probably Hakim's intention to change the succession-and this letter the Princess, fearing a trap, showed to the Khalif, at which he was very greatly annoyed. 'Ayn had been Ka'id (Commander-in-Chief) since 402, and had had one of his hands cut off in $40 \mathrm{I}$, and now on the 3rd of Jumada I. Hakim cut off his remaining hand, after which he sent him a present of 5, ooo pieces of gold and 25 horses; on the $13^{\text {th }}$ of the same month he had his tongue cut out and then sent other gifts, but after this the Ka'id died. Very many were put to death about this time, for the Khalif seemed to be suffering 
from an insane impulse to torture and slay; so great was the alarm that many fled from the city.

Since 4co the Khalif had been showing favour to the orthodox, but in the course of this year he changed his attitude, ceased to make gifts to the mosques, to the muezzins, doctors, etc., and disbanded the college which he had founded for teaching the Malikite canon law. More than this he treated the lecturers with great severity, and put to death Abu Bakr Antaki, the principal, and one of his assistants.

Either in this year or in 405 Hakim made very strict rules about women. He forbade them to go about the streets at all. The baths used by women were closed; boot-makers were forbidden to make outdoor boots for women, and so some of the boot-makers' shops were closed entirely. Women were forbidden to look out of doors or windows, or to go out on terraces. These laws continued in force until the close of the reign. A case occurred in which some old women who lived by spinning and selling their work to the merchants were neither able to dispose of it to their customers nor go out to buy provisions, and remained inside until their bodies, which showed that they had died of starvation. were found by the neighbours. Then this was reported to the Khalif he conceded that merchants who bought or sold with women might go to the doors of their houses and the women might pass out goods of money and receive its exchange, provided they did not show their faces or hands to the merchant or any passer-by in the street.

One day Hakim was passing the "Golden Baths" and heard a great deal of noise within. On making enquiry he found that there were women inside. $\mathrm{He}$ ordered the doors and windows to be walled up and left the inmates to perish of hunger. The pretext given for these new regulations was the libertinage of the Egyptian women. Hakim employed many harim spies, and by means of these old women he heard of various assignations and intrigues. On several occasions he sent a eunuch with a guard of soldiers to wait in concealment at the place of assignation, and when the woman appeared had her seized and thrown into the Nile. On other occasions he sent guards to private houses to demand by name women whose conduct had 
been unfavourably reported, and they were disposed of in the same manner. It seems almost impossible to excuse Hakim's conduct at this period by the supposition that he was an earnest but fanatical puritan : the frequency of new regulations, the constant changes in so many details, and the capricious character of his conduct all tend to make the theory of so many contemporaries that he was insane the more plausible.

In Syria the prestige of Egypt increased. Mansur, the son of Lu'lu' at Aleppo, had to ask Hakim's help against Abu 1-Hayja, the grandson of Sayf ad-Dawla, and this was given. In Ramadan of this year (404) Hakim issued a charter granting to Mansur Aleppo and its dependencies which were thus held as tributary to Egypt.

Early in 405 the Chief Qadi, Malik b. Sa'id al-Faraki, was put to death after holding office for six years, nine months and ten days. His income was estimated at I5, ooo pieces of gold. In Jumada the chief minister, Husayn b. Taher, was put to death and replaced by the two brothers, 'Abdu r-Rahim and Husayn, sons of Abu Sa'id. After holding office for sixty-two days they were put to death and replaced by Fadl b. Ja'far, who held office only five days and was put to death; then 'Ali b. Ja'far b. Fallah. Maqrizi mentions no other holder, but it does not follow that 'Ali held the post to the end of the reign as, for some reason, he omits all mention of Hakim's later years : no doubt the reason is to be found in his unwillingness to treat the closing phase of Hakim's strange career, and to these last years he makes no reference in any part of his work.

The Chief Qadi was replaced by Ahmad b. Muhammad ibn Abi l-Awwam, who retained his office until 413 , the year following the close of Hakim's reign.

Hakim now increased his habit of riding out. $\mathrm{He}$ began to use asses in preference to horses, and went out clothed plainly in black, wearing on his head a little linen cap without a turban. Orders were given that when he went out the officials were to remain in their offices arid not form an escort as had been the custom. As the year went on he went out more and more frequently until he was usualiy out six or seven times a day, sometimes riding on his ass, sometimes borne in a litter, and sometimes going in a boat on the 
Nile. He became more lavish than ever with his gifts, and presented estates to the owners of boats, to subordinate officials of various kinds, and to the Arab tribesmen of the B. Qorra. Amongst the gifts he made to these latter was the overlordship of the city of Alexandria and its suburbs.

In Syria Saktekin Shams ad-Dawla was made governor of Damascus, and this office he held until 408. He was a tyrannical and cruel man. Towards the end of his career he built the "New Bridge " below the citadel at Damascus, intending himself to be the first to cross it. One day when it was nearing completion he saw a horseman riding across the bridge. In great anger he sends down a messenger to arrest him. But the strange horseman turned out to be a messenger from Egypt with orders for his deposition from office.

At Aleppo Murtada ad-Dawla raised up many enemies. The Arabs of the B. Kalab tribe took up arms against him; he pretended to agree to their terms and invited them into the city to a feast : as soon as they entered he had the gates shut, arrested the chief men, and slew about one thousand. This took place in 402. Salih b. Merdas, one of the chief men who had been imprisoned, filed through his irons and escaped in this year, 405. When he is at large he ravages the whole country, and when Murtada goes out to check him he is himself taken prisoner by the Arab. Salih, however, really desired peace, and agreed to liberate Murtada for a ransom of 15 ,000 pieces of gold, 120 , 000 pounds of silver, and 500 pieces of stuff, the freedom of the women and others of his tribe who were still in prison, the equal division of the towns and lands of Aleppo between himself and Murtada, and the gift of Murtada's daughter in marriage. These extraordinary conditions were granted and Murtada was set free. But then he proved unwilling to divide the lands and towns of his principality or to give his daughter in marriage, so Salih makes war again and blockades Aleppo and starves it into unconditional surrender.

In 406 a quarrel sprúng up between Murtada and Fatah Kalai who was the governor of the citadel. Murtada considered that he had been instrumental in fom'enting Salih's rebellion. Finally Fatah openly revolted against Murtada and sent him the message, 
" Go out of Aleppo, or I give the citadel to Salih." Soon after this, as Murtada was in his palace near the gate Bab al-Jinan, he heard drums and trumpets and cried out: "Hakim, O Mansur: Salih, O Mansur, believing that the citadel was in the hands of the Arab chieftain: so greatly was he frightened that, without enquiring what was the real cause of the drums and trumpets, he fled out of the city with his family and escaped to Antioch, where he was given an asylum by the Greek Emperor. As soon as Fatah heard of his flight he proclaimed Hakim as sovereign over Aleppo, made terms with Salih and gave him half the revenues of the city and its suburbs, and presented to him the ladies of Murtada's harim whom he had not taken with him in his flight. Salih sent all Murtada's wives and the other ladies to Antioch, retaining only Murtada's daughter whom he married.

Fatah wrote an account of these events to Hakim, and the Khalif was very well pleased that he was now not merely suzerain over the ruler of Aleppo but the actual owner of the city. He conferred the title of Mubarak ad-Dawla wa-Saidha on Fatah. In the following year (407) Hakim wrote to the ciizens of Aleppo abolishing the imposts and various iaxes which had been paid. Fatah was given all the goods which had belonged to Murtada and was sent as governor to Tyre, after handing over the citadel of Aleppo to the Emir 'Aziz ad-Dawla, an Armenian slave who had belonged to Manjutakin. On this slave Hakim conferred the title Emir ul-Umara or "Supreme Prince," and presented him with a pelisse of honour, several horses with harness adorned with gold, and a sword of state. Later on the Emir revolted against Hakim.

Meanwhile very curious events were taking place in Egypt. In the course of 407 (though al-Magin says 408), a Persian da' $i$ named Muhammad b. Isma'il Darazi arrived in Egypt, a Batinite who believed in the transmigration of souls, and hoped to find at the Fatimid court a congenial atmosphere for his mystic creed. He attached himself to the Khalif, over whom he soon began to have great influence, and from whom he received many gifts and favours. In due course he succeeded in persuading the prince that he was an in- 
carnation of the deity, and wrote a book in which he taught that the Divine Spirit which God had breathed into Adam had passed on in due succession from prophet to prophet, through the Imam 'Ali, until at length it found its abode in the Imam Hakim. So great was his influence over the Khalif that much of the public business was given into his hands, and all who desired to approach the Khalif had to pay court to the $d a^{\prime} i$. The heir elect seems to have fallen into disfavour about this time. He was sent away from Cairo but given the important post of governor of Damascus. After he had been in Syria for some time he was suddenly attacked by a band of men who, after slaying several of his companions, put him in a box and carried him to Egypt. There he was released and, a little later, was sent back to Damascus. No explanation of this strange event is suggested, but it was generally believed that he was thus treated by the Khalif's orders.

Amongst some of the more advanced Shi'ites many were found to follow the new doctrines of Darazi, and the $d a^{6} i$ accompanied by a band of followers went down to the Old Mosque where he read from the book he had written. According to an account given by alMasin, a Turk, shocked at the blasphemies which occurred in this reading, fell upon Darazi and killed him, after which his house was pillaged, and a tumult followed which lasted for three days. The Turk was arrested and put in prison, and was then brought to trial on another charge for which he was executed. For a long time the Turk's grave was visited by the orthodox who regarded him as a martyr. But this account is not strictly correct, for Darazi was not killed at that time. According to Abu 1-Mahsin, the most weighty authority, Hakim did not openly endorse Darazi's teaching; when the tumult arose in the mosque Darazi escaped and received money from Hakim, and with this retired to Syria where he preached in the mountainous parts where the people were very ignorant, and amongst them he obtained many disciples and founded a sect, the Druses, which still exists in the Lebanon. In religion these Druses hold a kind of pantheism, which in many respects verges upon agnosticism, but has a pure morality, in spite of the many charges which have been made 
against this as against every other religion which keeps its creed a secret from the outside world.

About the same time, or perhaps a little after, a Persian from Farghana named Hasan al-Akhram, also appears as using his influence to persuade Hakim of his deity, or to develop the ideas which Darazi had already instilled into him. This man formed a party on the conventional lines of the extremer Shi'ites, entirely discarding all the traditional observances of the Muslim religion. One day he went with a hand of fifty followers to the Old Mosque, where he found the Qadi sitting and hearing cases. After treating the bystanders roughly, they present a question to the Qadi, beginning their words with the form " In the name of Hakim, the merciful, the compassionate," applying to him the terms usually applied to God. The Qadi raised his voice and protests against this with great indignation. The people were so angry at the blasphemy that they fell upon Akhram and his followers : of the latter several were killed, but Akhram escaped.

The most famous of these du'at, who at this time advocated the deification of Hakim, was Hamza b. 'Ali b. Ahmad Hadi, a native of Zawzan in Persia. The Druses regard him as their founder, and date their years from the "Era of Hamza," which is placed in A.H. 408. It seems that his teaching was earlier than that of Ahmad the Qadi (405), and so probably he was in private conference with Hakim from somewhere about 405 until he made public declaration of his doctrine in 408. He dwelt in the Mosque of $\mathrm{Bir}$ at Mantarea, originally the tomb of an 'Alid who had been put to death in 145, afterwards known as the Mosque of Tibr after a minister who served under Kafur, and was one of those who had tried to resist the entry of Jawhar. He preached and invited the people to accept the teaching already expounded by Darazi, and sent out missionaries of his doctrines to various parts of Egypt and Syria. Hakim was greatly influenced by Hamza, and was induced by him to discard all the outward observances of Islam, ceasing to visit the mosques, or to take part in prayer. Under the pretext that the Arabs were a danger to travellers he suppressed the pilgrimage to Mecca and ceased to send the veil to the "House of God," all of which caused 
great disgust to the orthodox. Hamza and twelve of his disciples, the traditional number of the Shi'ite nakibs, were in constant attendance on Hakim. It seems that Hamza was the real founder and teacher of Hakim's deity, and that Darazi was one of his converts. But the details of the formation of this sectarian development during the years 405-408 are full of obscurities : it does not seem safe to follow the sacred books of the Druses who idealised the whole matter. We do not find ourselves on solid ground until 408, when the claims of Hakim to deity were publicly proclaimed and admitted by the Khalif himself. It is said (by Severus) that Hakim claimed to have a knowledge of secret things, and tried to support this claim by evidence which he gleaned from his spies. But Severus' evidence must be regarded with some suspicion: a Syrian Christian he heard of the events in Egypt only at second hand, and is very obviously influenced by strong prejudices. He refers to this claimed omniscience of Hakim the incident of the letter which read: "We have endured injustice and tyranny, but we are not willing to endure impiety and folly. If thou knowest hidden things, say the name of him who wrote this letter," an incident which seems to belong to the early days of the Khalif al-Mahdi in Kairawan. Severus further tells us that when Hakim's name was mentioned in the khutba all present rose out of respect; but in Fustat the people made a prostration at this name. He is referring, no doubt, to reported conduct of Hamza's followers. He says further that there were some people who, when Hakim appeared in the streets, used to prostrate themselves on the ground and cry out: "O thou only one, thou alone, thou who givest life and death": this is exactly what might be expected of the extremer Shi'ites, and is in no way incredible. At this time all persecution of Christians and Jews entirely ceased; obviously the Khalif no longer regarded Islam as in any way superior to those other religions. Persons who had turned Muslims were permitted to return to their former beliefs icontrary to Muslim law they were protected from all punishment, but it is obvious that at this juncture Muslim! law was not in any sense observed in the Fatimid state. Severus tells us that some Christians and Jews came to the 
Khalif and said: "My God, I desire to return to my former religion" : and Hakim replied : "Do as seems good to you." According to the books of the Druses : "Although it is a precept to make war with the unbelievers, our lord has abolished this precept so far as concerns Jews and Christians." The Druses refer this to the era of Hamza, i.e., 408 A.H., but Severus puts it in the year 736 of the " era of the Martyrs," that is A.H $4 \mathrm{II}$, the closing year of Hakim's reign, and dates the beginning of the persecution of Christians from 402 , taking the destruction of the great Church in Jerusalem as the beginning of the persecution, that is to say, the beginning of the time when active steps were taken which reached to Syria as well as Egypt, and in this agrees with Abu 1-Mahisin, but Maqrizi puts the destruction of the Church of the Resurrection in 400 so that the end of the persecution, which lasted nine years, would come in 408-409, when Hakim had assented to the public declaration of his deity which seems to be the more probable date.

Towards the end of the nine years of persecution it was reported to Hakim that some converts from Christianity had been celebrating the rites of their former religion privately in houses, but he took no steps to punish them, and this emboldens others to do likewise. If this was so it would seem that there was no formal decree of toleration but simply that the penal regulations were permitted to sink into oblivion. Then some attended on the Khalif and asked permission to revert to their former religion. Hakim asked where were their girdles, crosses, and other badges?-they produced them from under their clothes. The Khalif made no rebuke but told them that they could do as they pleased, and sent them with an attendant to the office where they obtained letters of protection. After this many unwilling converts did the same, until most of those who had changed their religion from fear had returned to their former faith.

The monk Yamin next procured the exiled Patriarch Zacharias an interview with the Khalif, which took place in the monastery of St. Mercurius at Sahran. In the course of this interview Hakim gave permission to the Christians to re-open their churches, to restore those which had been destroyed, to recover building 
material removed at the time when churches were being demolished, and to regain possession of gardens and property attached to the churches and monasteries. The Christians were no longer required to wear distinctive badges, or rather the disuse of those badges was tacitly condoned, and were allowed to sound bells. Ibn Khallikan refers this toleration to $4 \mathrm{II}$, which agrees with Severus and with Bar Hebraeus, who speaks of this change as taking place shortly before Hakim' was killed, and adds that at this time many of the Christians who had gone abroad returned to Egypt. Probably breaches of the persecuting laws began to be condoned in 408 or soon after, and these increased gradually as it was seen that they could be made with impunity.

Meanwhile the extremes to which the followers of Hamza were prepared to go also increased. Some of the courtiers on entering the Khalif's presence saluted him, "Hail to thee, only and unique one, hail to thee who givest life and death, who bestowest wealth and poverty." Having in view the peculiar religious tendencies of the extremer Shi'ite sects, it must not surprise us that there were some apparently sincere in their acceptation of the divine character of the Imam, although the bulk of the people remained sober and orthodox Muslims. One of the adherents of Hamza's doctrines who was at Mecca struck his lance on the sacred Black Stone and said: "Why, O foolish ones, do you adore and kiss that which cannot be of any use to you nor injure you, whilst you neglect him who is in Egypt, who giveth life and death?"

Ibn Khallikan tells us that one day a Qur'an reader was reading at court the verse: "And they will notI swear by the Lord-they will not believe, until they have set thee up as judge between them on points where they differ" (Qur. iv. 68), pointing the while towards the Khalif. Ibn al-Mushajjar, a devout man who was present, then recited the verse: "O men, a parable is set forth to you, wherefore hearken to it. Verily, they on whom ye call beside God, cannot create a fly, though they assemble for it; and if the fly carry off aught from them, they cannot take it away from it. Weak the suppliant and the supplicated" (Qur. xxii. 72). At this the Khalif changed countenance; to Ibn 
al-Mushajjar he presented roo dinars, to the reader he gave nothing. But afterwards a friend said to Ibn Mushajjar: "You know al-Hakim's character, and are aware of his frequent prevarications : take heed lest he conceive a hatred for you and punish you later. You would then have much to suffer from him. My advice is that you get out of his sight." Ibn al-Mushajjar took this advice seriously and set out on the pilgrimage to Mecca, but was ship-wrecked and drowned.

The years 408 to 4 II were entirely abnormal in the history of Egypt. It has been suggested that the entire change in Hakim's conduct during these years was due to his being now initiated into the higher grades of the Isma'ilian sect, and thus he was now disposed to disregard all forms of religion. But it seems to be very dubious how far the regular Isma'ilian system had remained in vigour in Fatimid Egypt. The state was professedly Shi'ite, the Chief $\mathrm{Da} i \mathrm{i}$ held the regular conferences required by the rules of the brotherhood, and undoubtedly initiates were admitted: but since the sojourn in Egypt it rather seems that the sect as a religious organization had greatly weakened, save in the one respect that it was regarded with loyalty by the extremer Shi'ites in Persia, and that from Persia more especially there was a constant stream of pilgrims, enthusiastic sectaries whose enthusiasm was, if anything, a source of embarrassment to the Egyptian government, whose interests were now plainly political. Hamza, Darazi, and, later on, the originators of the sect of Assassins, were all Persian Shi'ites who came to visit Egypt. It seems more probable that Hakim's new attitude was entirely due to the influence of these Persian visitors.

In the year 409 Hakin was riding in the streets and saw what he supposed to be a woman standing in the street, a plain breach of the regulations in force. At once Hakim rode over to her and found that she was holding out a petition in her hand. He ordered one of his attendants to take the paper and arrest the woman. When they laid hands on her it turned out that it was only a guy of paper, and the document she held out was full of charges against the chastity of the Princess Hakim's sister. Hakim went home in a towering rage. He abused his sister for giving ground for such re- 


\section{FATIMID KHALIF, AL-HAKIM}

flections to be made on her honour, and spoke to her many harsh words. More than once before this he had treated her harshly when she had ventured to remonstrate with him on his various cruelties, but this was an attack graver than he had ever made previously.

Next day Hakim turned loose his mercenaries, Arabs, Berbers, Greeks, and negroes, upon the city. For three days they broke open houses, pillaged, slew those who resisted them, violated women, and carried off maidens of the best families, and burned a great part of Fustat. Each day Hakim rode out to the cemetery of Karafa and looked down on the suffering city. Many of the citizens came around him to implore mercy, but he remained unmoved and gave no sign of hearing them. On the fourth day the Sherifs assembled in the mosques lifting Qur'ans to heaven and implored divine assistance. So piteous was the condition of the people that many of the Turkish guards were moved and took their part, and in this they were soon joined by the Berbers, both doing their best to restrain the bestial ferocity of the negroes, until the whole place was raging in civil war. At length some of the Turks went to Hakim, and in no measured terms called on him to interfere and stop this terrible state of affairs. Hakim replied quite cooly deploring the excesses of the soldiery, and agreeing with the Turks that it ought to be stopped. He then rode down into the city on his ass and stopped the conflict. After that he called the Turks and Berbers round him, expressed the greatest regret for the suffering which the city had had to undergo, protested that he did not at all desire such an unhappy event, and that it could not be avoided, and published a general amnesty. As soon as things settled down it was found that about a third of the city had been burned, and about a half pillaged. The citizens had much trouble in recovering their ravished wives, daughters, and sisters, most of whom had been dishonoured by the negro soldiers. Some of the women had committed suicide to avoid this shame. Many of the citizens went to Hakim and asked him to get back their women for them. Hakim told them to ransom them from their captors and promised to reinbursbe any sums which were laid out in this manner. One of the townsmen reproached him very harshly for this great 
disgrace to a Muslim community, and expressed the hope that the women of the Khalif's own family would suffer the same as their wives and daughters. Hakim bore this reproach patiently and made a mild reply.

Although this atrocious deed had made Hakim feel that he had revenged himself on those who had reflected on his sister, he had by no means forgiven her. After upbraiding her in no measured terms he informed her that he would send some women to examine her and find if she really were a virgin or not. The Asiatic historians who make most reference to the Princess describe her as a woman of the noblest character and of the highest chastity, and represent this as a deliberate and insane insult offered by her brother. It is not at all clear that this is a true estimate. Later on we find her as a woman of undoubted ability, but unscrupulous character. At the same time it is extremely probable that the members of Hakim's family had graver reasons for alarm than anyone else, if indeed it be true that he was now showing plain signs of a disordered brain. At any rate when Hakim made this threat: she was greatly alarmed; it may be that she feared such an examination, or it may be that she deeply resented the insult. In her alarm she went to Yusuf b. Dawivas ad-Dawla. Although one of the great nobles of Egypt Yusuf abstained from attending the court and had so abstained for some time, being thoroughly alarmed at Hakim's conduct, and was careful to meet the Khalif only at public functions which he could not avoid. One time Hakim at such a parade asked him to visit him in his palace, but Yusuf did not make the desired visit. The next time they met in public Hakim reproached him for this, and Yusuf replied plainly that he would rather not go to the palace; if Hakim had any evil intention towards him he would rather wait at home to be summoned to death than to go to the palace, be killed there, and thrown to the dogs. At this reply Hakim only laughed, but Yusuf had serious fears that sooner or later the Khalif would have his revenge, and probably a cruel one.

The Princess sent to Yusuf and asked for an interview with him at night. This was arranged and she went to Yusuf's house and explained to him the great dangers threatening them both. The best thing to do 
would be to arrange Hakim's death : "You," she said, " will be made general of the armies, minister of the empire, and guardian of the young prince. I shall live quietly in my palace as befits my sex and take no part in business." Some reports say that she also promised to marry Yusuf. To all this Yusuf agreed. She asked him to supply two absolutely trusty men, and these he provides. A plan of assassination was agreed upon, and the two cut-throats were presented by her with a Maghrabi dagger each. With reference to this account, which is given by Bar Hebraeus, and outlined by alMakini, Maqrizi says : "No credit should be given to what the Asiatic writers say in their books, that this prince perished by the plots of his sister. But God alone knows the whole truth" (Maq. ii. 289). It is important to note that Severus of Ashmunayn, who wrote only thirty years after these events, makes no mention of the Princess in this connection, though his tendency is to repeat all gossip unfavourable to the Fatimids : he simply states that the details of Hakim's disappearance were unknown.

According to Ibn Khallikan, Hakim went out late in the night of 27 th Shawal 4II, and spent the whole night going about on the Mokattam hill. At daybreak he was near the tomb of Fokkai, and thence went east to Hulwan, about five miles from Cairo, accompanied by two attendants. He then met a company of Arabs, nine in number, who had a request to make of him. He told them to go to the palace, and sent one of his attendants with them. For some time he continued with the second attendant, then told him to go back also. At that time he was still near the tomb of Fokkai. The second attendant returned to the palace and left the Khalif alone on Mokattam. Next morning he did not return, and for three days no sign of him was seen; then, on Sunday, the and of Dhu $1-\mathrm{Za}^{\prime} \mathrm{da}$, the eunuch Nesim, who was the chamberlain, and a number of other officials, went out on the hills to make a search. At length they reached the monastery known as Dayr al-Kosayr, and near there they found Hakim's ass with its saddle on but its legs hacked off. Following the footsteps of the ass, which were accompanied by the footprints of two men they came to a hollow where they found the Khalif's clothes with marks of cuts, but 
the buttons not undone. No body was ever found. It was assumed that Hakim had been murdered, and' that his arms had been cut off before the clothes were removed. After the discovery of the ass and of the clothes had been reported, the Princess considered it expedient to have Hakim's infant son proclaimed Khalif, thus avoiding the claims of 'Abdu r-Rahim, the heir designated by Hakim, and it seems that the main evidence for her supposed complicity with the murder rests on this act which assumed that he must be dead, though it is difficult to see how she could have acted differently under the circumstances.

Al-Mahisin is reported as saying that Hakim went out, and that after sending back Nesim and his squire, he had as companions only a page and young slave: at the time he was filled with apprehensions as he knew from his horoscope that the night was one of greot peril to him. When he was on Mokattam he said: "We belong to God and return him ": then clapping his hands together he added, "Thou hast appeared then, O dismal sign," referring to the star whose appearance he took as the warning of his death. Going along the hillside he met ten men of the B. Qorra who had a request to make to him, and said that they had often waited in vain at his palace door. Hakim orders them to be paid 10,000 pieces of silver from the treasury, and directs his page to go with them and draw the money for them. They objected that it might be that the Khalif was angry with them for interrupting his walk, and that perhaps the order in the page's hand might privately direct that they were to be put to punishment, so they requested that he would also give them a safe conduct, and this the Khalif gave. Hakim and the young slave then go on and enter a valley where the two men sent by Yusuf are lying in ambush. They came out and fell upon him just as the day was dawning. At their appearance he cried out, "Wretches, what do you want?" They cut off his two arms, open his stomach, and tear out the entrails, and wrap the body in a robe. They then slew the slave, cut the traces of the ass, and carried off the body to Yusuf. He took it to the Princess, who made presents to him and to the two murderers. She then sent for the wazir, revealed to him what had happened, and made him 
promise secrecy. She persuaded him to write to 'Abdu r-Rahim at Damascus, and at the same time sent an officer named 'Ali b. Dawud to Ferma to seize 'Abdu r-Rahim on his way to Egypt and carry him to Tannis; and also she sent instructions to the governor of Tannis. Next day it was observed that Hakim did not return. Abu Arus would not allow the gates of Kahira to be opened, stating that the Khalif had ordered them to be closed the day before, and no search was made until the following day. The Princess had conferences with the chiefs of the Katama tribe and other leading persons and, with the help of lavish presents, induced them to recognise Hakim's son as his successor, although they had already given formal recognition to 'Abdu r-Rahim. On the seventh day she dressed the child in rich robes and sent for Yusuf, whom she declared to be ustad or guardian. Then the child was taken out in state, the wazir proclaimed him as Khalif, and he was generally recognised.

The facts of Hakim's disappearance were never fully known. One report, as we have seen, was that he was murdered. Of the murder Maqrizi gives another account which exculpates the Princess. He says: "Masihi relates that in the year 415 a man of the family of Husayn was arrested after raising up rebellion in the southern part of Upper Egypt. This man confessed that it was he who had killed Hakim. $\mathrm{He}$ said that there were four accomplices of the crime, and that they afterwards fled to different parts. He showed a piece of the skin of Hakim's head and a fragment of the piece of cotton with which he had been clothed. He was asked why he had killed him. He replied: "Out of zeal for the glory of God and of Islam." Further questioned as to the way in which he had committed the crime, he drew out a dagger and striking it to his breast he cried, as he fell dead, "That is the way I killed him." His head was cut off and sent to the Khalif with all that was found in him " (Maq. ii. 290).

The Druses of course believe that he disappeared like others of the Imams before him, going away in sorrow from a world which was not worthy of his pure doctrine and that he lives still in concealment to reveal himself in due time when the world is ready for him. 
Other persons believed that he had hidden himself because he was disgusted at the state of affairs and weary of the throne, and was living contentedly in obscurity. Bar Hebraeus tells us of a widespread belief in Egypt that Hakim had been recognised as a Christian monk at Sketis. Severus says that for sixteen years there were constant rumours of his return. A certain proselyte from Christianity named Sherut claimed to be the Khalif and called himself Abu 1-'Arab. In voice and appearance he very closely resembled Hakim and had many followers. About 427 he was in Lower Egypt, and a certain Arab who believed in him provided him with a tent where he lived for some time. Very often he used to give the Arab rich presents of clothes and arms, but himself lived in the strictest simplicity. At last the government heard of him and he fled, after some twenty years personation of the exKhalif. Abu 1-Feda tells us of a pretender named Sikkin who revolted in 434, and was seized and hanged (Annal. Moslem iii. II9). De Sacy thinks that this Sikkin was the same as the Sherut of Severus. Strangely enough every one of these claimants found enthusiastic supporters, as though Hakim had been the most popular of all the Khalifs of Egypt. 


\section{$\mathrm{X}$}

THE SEVENTH FATIMID KHALIF, AZ-ZAHIR (A.H $4 \mathrm{II}-427=$ A.D. $\quad \mathrm{IO} 2 \mathrm{I},-\mathrm{IO} 35)$

ON the "Day of Sacrifice," 4II, seven days after Hakim's disappearance, his son Abu 1-Hasan 'Ali azZahir li-'izazi-dini-llah (" the triumphant in strengthening God's religion"), then a boy of sixteen years of age, was recognised as Khalif. The heir designated by Hakim, 'Abdu r-Rahim, was still in Damascus, but the Princess wrote to him ordering his immediate return to Egypt. Instead of obeying this summons he declared himself the independent ruler of Damascus, and made himself popular amongst the citizens by repealing the many vexatious regulations which Hakim had put in force. But this popularity did not last long : he soon made himself odious by his avarice and grasping extortions, and craftily utilising this, and the discontent of the soldiers who did not receive the gratuities which they expected, the Princess contrived to gain a party of supporters, and by their help had him arrested and sent in chains to Egypt where he was imprisoned for some four years, then fell ill and died, perhaps poisoned, three days before the Princess herself died.

For the first four years of az-Zahir's reign the whole power was in the hands of his aunt, the Princess Royal. According to Ibn Khallikan the Princess sent for Yusuf b. Dawwas, the noble who the Syrian writers describe as having conspired with her to arrange the murder of Hakim, and made him a present of a hundred slaves. After the wazir had gone home she sent the eunuch Nesim after these slaves, and conveyed her orders to them that it was their duty to slay Yusuf, as he was the person responsible for the late Khalif's assassination. In consequence of this Yusuf was put to death. Soon afterwards the Princess contrived the 
death of two of the wazirs who succeeded him, and throughout the whole four years of her rule she showed herself cruel and vindictive. She died in 416 , and the chief control then passed into the hands of a committee of three sheikhs who paid a daily visit to the Khalif, but excluded him from all participation in the administration.

'The year of the Princess' death saw the beginning of a terrible famine in Egypt as the result of a series of bad Niles, and the resultant distress lasted all througin 416 and 417 . In many cases the starving villages took to brigandage, an evil to which the country is always more or less exposed. Sometimes outbreaks are due, as in this case, to dire distress and consequent recklessness; sometimes it means the revival of ancient feuds between village and village, or family and family, so that it is no more than an outlet for intermittent intertribal feuds and private quarrels between villages or families; but in time of distress these become more acrimonious and turn against strangers and travellers. Even the pilgrims on their way through Egypt were attacked. Regulations were passed to prevent the slaughter of cattle for fear that they would be exterminated altogether; camels were scaice as many were killed because it was impossible to provide them with food, and poultry could hardly be procured. Crowds assembled before the palace crying, "Hunger, hunger. $\mathrm{O}$ Commander of the faithful, it was not thus under thy father and grandfather."' Then the slaves, starving and miserable, revolted and swelled the numbers of brigands on the roads. In many places the citizens formed themselves into "Committees of safety," and the government allowed them to arm and slay revolted slaves in self defence. The state treasury was practically empty, for it was impossible to collect taxes, and even the palace slaves and officials were in a starving condition. The misery reached its height in 418 when 'Ali b. Ahmad al-Jarjarai, the same whose hands had been cut off by Hakim, was appointed wazir. As the rear began (in the early part of February) the conditions were such that barricades were erected across the streets of Cairo to keep out the brigands and slaves, and the wazir himself was for some time a prisoner in his official palace. Later in the 
year, however, there was a good inundation, and this restored plenty, so that in 4I9 the country was once more under normal conditions and order was restored.

A curious event of 416 was a persecution of the Malikite school of jurists. At that time the Maliki system was the prevailing school of thought in orthodox Egypt, though now it is for the most part confined to Upper Egypt, the Shafi'i system replacing it in Lower Egypt. Neither of these, of course, was acceptable to the Shi'ites, who demanded that the problems of canon law should be treated according to the teaching of Ja'far as-Sadiq (cf. p. 96 above). Hakim had, in 400 , founded and endowed a college for instruction in the Malikite system, but in 404 it was suppressed and its head was put to death. Nothing of this sort was attempted now, but all the canonists of the Maliki school were banished from Egypt. No doubt they were regarded as leaders of the Sunni element as against the Shi'ite Khalifate.

In 418 when there was every prospect of a return to prosperity as the result of an abundant Nile, the Khalif was able to make a satisfactory treaty with the Greek Emperor, Constantine III. It was agreed that the Fatimid Khalif should be prayed for in the khutba in every mosque in the Byzantine dominions, and permission was given for the restoration of the mosque at Constantinople, which had been destroyed in retaliation for the destruction of the Church of the Resurrection in Jerusalem; whilst, on the other side, the Khalif agreed to permit the rebuilding of the Church at Jerusalem. This freed the Khalifate from one source of anxiety.

At the time of az-Zahir's accession the authority of the Fatimids was hardly recognised in Syria, but this was soon altered by the ability and enterprise of Anushtegin ad-Dizbiri, who was the governor of Caesarea. His first important action was against Salih b. Mirdas, the Arab chieftain who had taken Aleppo from Murtada and had now established himself as an independent prince. In 420 Anushtakin met him at al-Ochuwana, a village near Tiberias, and defeated and killed him. He had next to deal with Hasan b. Mufarraj, who was once more in revolt. This he did so effectually that Hasan was obliged to flee and take 
refuge amongst the Greeks. It is worth noting that the old mischief maker, Husayn al-Maghrabi, who had fled from Egypt in 40o, ended a career of great vicessitudes in 418 . After the failure of the revolt under Hakim he had gone to the court of the Daylamite prince Baha ad-Dawla, and stayed with his wazir Fakhr al-Mulk. But the Khalif of Baghdad suspected him of being a Fatimite spy, and ordered Fakhr to get rid of him. Fakhr, however, pleaded on his behalf, and at length obtained the Khalif's favour for the fugitive who was kindly received in Baghdad.

During the latter part of az-Zahir's reign Fatimid influence had become supreme in Palestine and Syria, save only in the few northern districts which remained subject to the Greek Empire. It seemed indeed to be the triumph of the Fatimids, but the appearance was fallacious. The Fatimid Empire in Asia was held together only by the genius of Anushtegin, who was able to avail himself of the favourable conditions which preceded the great Turkish storm, which was even then gathering in the east.

It was the policy of the Princess Royal and of the committee which held supreme power after her death to keep the Khalif in the background, and exclude him from all real part in the work of government. It was as well, perhaps, that his freedom was rather circumscribed for, as he grew up, he gave signs of a cruel temperament which in some directions surpassed that of his father. He was wholly occupied with the pursuit of pleasure, finding his interest in the company of singing girls, buffoons, and others of like kind, and showed no desire to take part in public affairs. In 424 he invited the palace girls to the number of some 2,660 to a festival: when they came to the feast they were led to one of the mosques and taken inside; the doors were then bricked up and the unfortunate girls were left to starve. For six months the mosque was left unopened and the bodies unburied. Many other instances of wanton cruelty are related of him.

In 427 az-Zahir fell sick of the plague, and as he, grew worse he was taken to the "Garden of the Strand" at Maqs, then the port of Cairo, where he died on the isth of Shaban, leaving the Khalifate to his son alMustansir, then a child seven years of age. 


\section{I}

\section{THE EIGHTH FATIMID KHALIF, AL-MUSTANSIR$$
\text { (A.H. } 427-487=\text { A.D. } 1035-1095)
$$

ABU Tamin al-Mustansir bi-llah (" the seeker of aid from God ") was proclaimed Khalif at his father's

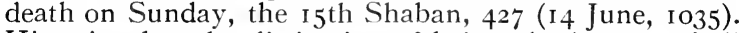
His reign has the distinction of being the longest of all the Khalifates either in Egypt or elsewhere.

Again we find the influence of a woman of the royal family predominant in the state, this time of a black ex-slave woman. In Cairo there were two Jewish merchants, Abu Sa'd Abrahim and his brother Abu Nasr Sa'd ad-Dahir, sons of Sahl. The Khalif azZahir had bought a black Sudani slave girl from Sa'd ad-Dahir, and she was the mother of al-Mustansir. During the earlier years of the reign the influence behind the throne was in the hands of the Sudani Queen Mother and her former master, the Jewish slave merchant. This influence was restrained so long as the wazir al-Jarjarai lived, but all check upon it came to an end at his death in 436 .

The old faction fights between Turks and Berbers had now long passed away. Under Hakim we have seen the formation of new parties, Turks and negroes, rival groups of mercenaries in the Khalif's employ; the Arabs and Berbers, so far as they were not absorbed in the mass of the population, joining with the Turks in opposition to the negro regiments. The Queen Mother, herself a Sudani negress, threw the whole weight of her influence on the side of the black troops.

The period of al-Jarjarai's administration was one of prosperity in Egypt and, for the most part, of success in Syria. Syrian affairs mainly centre round Aleppo 
where Hakim had appointed 'Aziz ad-Dawla governor in 406, but his subsequent conduct was far from pleasing to the Khalif. After renewing the fortifications and making his own treaty with the Greeks, he commenced striking an independent coinage and then ceased to pay tribute to Egypt. Indeed, at the time of his disappearance Hakim was actually preparing an army to send against Aleppo. 'Aziz ad-Dawla, however, managed to make peace with az-Zahir and the Princess Royal, and nothing of importance transpired until his murder in $4 \mathrm{I} 3$ which popular opinion ascribed to Badr the governor of the citadel. No doubt Badr expected that getting rid of ad-Dawla would leave him supreme in the city, but next year he was expelled by the Fatimid government and two entirely independent governors were appointed, one for the city, the other for the citadel.

Within the next few months a formidable rising took place in which all the Arab tribes of Syria joined. They acted in three bodies, one led by Salih b. Mirdas, who thought this a good opportunity of recovering his former fief, attacked Aleppo; a second led by the old agitator Hasan b. Mufarraj overran Palestine; and a third under Sinan moved against Damascus. The Khalif sent his general Anushtakin to deal with these revolts, but he received a serious check, and Salih, after taking possession of Aleppo, passed on to Hims, Ba'albek, and Sidon, so that in 4I6 the Fatimid power in Syria had almost passed away. In 420 Anushtakin reinforcements had recovered possession of Damascus. Advancing against Salih he had an engagement at Uqhuwana in which Salih fell, although Asushtakin was not able to press on to Aleppo. The government of the city was now divided between Salih's two sons, Mu'izz ad-Dawla taking the citadel, his brother Shibl ad-Dawla holding the city. After a short time, however, Shibl ad-Dawla took command of the citadel as well, compensating his brother with possessions outside the city. After this he commenced a series of successful raids against the Greeks, and was able to inflict a defeat upon the governor of Antioch. These raids became so serious that the Greek Emperor made an expedition against Aleppo, but was defeated by Shibl ad-Dawla and forced to retreat. 
When al-Mustansir succeeded to the Fatimid throne in 427 Shibl ad-Dawla thought it prudent to conciliate him by large gifts of booty won from the Greeks, and the Khalif confirmed him as governor of Aleppo. Two years later Anushtakin considered that the time had come to make another attempt on Aleppo, and advanced against the city with a large army. Shibl ad-Dawla went out against him, and a battle took place near the Orontes in the month of Shaban 429, in which the forces of Aleppo were defeated, Shibl ad-Dawla slain, and his brother $\mathrm{Mu}^{\prime} \mathrm{izz}$ ad-Dawla compelled to flee. After this Mu'izz ad-Dawla went to 'Iraq, leaving deputies in charge of Aleppo under whose rule the city quickly fell into a state of anarchy, so that Anushtakin was able to take possession and appoint his own governors, and thus Aleppo once more became part of the Fatimid empire.

This was the zenith of the Fatimid power in Syria and was mainly due to the capacity of Anushtakin, and after this the Fatimid Empire began a rapid decline. Anushtakin had himself aroused the jealousy and suspicion of the wazir al-Jarjarai, and had to meet his most serious opposition from the court at Cairo. Ill-advised by his wazir, al-Muntasir granted Aleppo as a fief to Mu'izz ad-Dawla, and Anushtakin was compelled to conduct him to the city to be invested. On the way Anushtakin, already ill and much mortified by the deliberate destruction of the work he had so efficiently executed, died (A.H. 433), and his successor Nasir adDawla, whom we shall see afterwards as a sinister character in Egypt, placed Mu'izz ad-Dawla in possession of the city.

To survey briefly the subsequent history of Aleppo which now ceased to be of primary importance to Egyptian history : Mu'izz ad-Dawla was confirmed in his appointment by the Khalif in 436 , and at the same time made good terms with the Greek Empress Theodora, and with the Saljuk Tughril Beg who was Sultan at the court of the 'Abbasid Khalif. In 449 he exchanged Aleppo for Bairut, 'Akka, and Jubail, being replaced by two Fatimid governors at Aleppo. In $45^{2}$ Mahmud, his nephew, tried to seize the city and succeeded in occupying it for a short time, after which it was re-taken by Mu'izz ad-Dawla, who then held it 
until his death in 453. Before he expired he appointed his brother 'Atiya as his successor, but Mahmud made war against his uncle and, helped by the Greeks, recovered Aleppo in 457. Soon after this, as Mahmud was convinced that the Fatimid rule in Syria was in its final decay, he made his submission to the Khalif of Baghdad and his Sultan Alp Arslan. This change was unpopular in Aleppo where the people were attached to the Shi'ite sect; there was no open resistance but clearly expressed discontent. The worshippers stripped the great mosque of its prayer mats, saying that these had been bought or given for Shi'ite services; let those who wished to pray in the Sunni fashion buy others for themselves.

The wazir al-Jarjarai died in 436 , the year following the death of Anushtakin. His disappearance opened the way to an increase of faction fighting and court intrigue in Cairo. The next wazir was Ibn al-Anbari, who soon provoked the enmity of the Queen Mother. It seems that Abu Nasr, Sa'd ad-Dahir's brother, was insulted by one of the wazir's servants, and when Abu Nasr complained he only obtained a rough answer from the wazir. By the plots of S'ad ad-Dahir and harim influence, Ibn al-Anbari was deposed and replaced by the renegade Jew, Abu Mansur Sadaqa, in whom the Queen expected to find a docile instrument. But Abu Sa'd continued his intrigues against Ibn al-Anbari, and finally secured his execution in 440. But this proved his undoing, for Sadaqa began to fear that the same fate might lie in store for him also, so he bribed the Turkish guard to assassinate Abu Sa'd, and Abu Nasr was put to death on the same day. In retaliation the Queen Mother procured the assassination of Sadaqa. The next wazir was a mere creature of the Queen and imported more negro troops in large numbers to counterbalance the Turkish guard, whilst the Khalif and his supporters brought in more Turks and had the wazir murdered. The next wazir held office only three months and then was deposed. For the six years following $(436-4+2)$ the domestic politics of Egypt centered entirely in the struggle between the Turkish mercenaries and the negro troops.

Then in 442 there came forward once more a capable wazir in the humble fisherman's son al-Yazuri, as his 
name denotes a native of the coast village of Yazur, near Jaffa, and he held office more or less firmly for a period of eight years.

There can be no doubt that he was a perfectly earnest reformer, so far as his knowledge extended, and that some of his experiments were rash and unsuccessful does not detract from his personal sincerity. One of his first measures was to sell the government stores of corn at the lowest current prices, thus bringing down the price of corn throughout the country and forcing the merchants to put their stock upon the market at prices which suited the people. Incidentally this involved a severe loss to the revenue, and, a more serious result, there was nothing available when soon afterwards a bad Nile produced general scarcity, so the country had again an experience of famine and then of plague. In these circumstances he appealed to the Greek Emperor, Constantine Monomachos, and arrangements were made for a supply of some two million bushels which eased the situation. For several seasons when the Niles were bad this assistance continued until Constantine died in 44i. The next Greek ruler, the Empress Theodora, tried to drive a harder bargain and stiplated for a full alliance, defensive and offensive, as the price. To this the wazir was not willing to agree, for shortage in Egypt might not happen every year, whilst such an alliance would be permanent. As a result the supplies were stopped and minor hostilities took place in the neighbourhood of Antioch. The stoppage was not of great importance as next year there was an exceptionally good Nile and Egypt was filled with abundance. Taught by experience the wazir bought freely and laid up stores for next year's possible requirements. At the same time he took active measures to prevent money-lenders seizing the standing crops or merchants buying the unreaped corn as it stood at a low figure, and so protected the thriftless people from the wrongs which had most preyed upon them in the past.

In his dealings with the Copts he was harsh. Again as in the anti-Christian legislation of Hakim we observe the great unpopularity of those who were hereditary tax-collectors and who were suspected, no doubt with excellent reason, of defrauding the revenue. The 
strict organization introduced under the first Fatimid Khalif had been allowed to grow slack, its continuance meant constant effort and unceasing supervision, and this sustained effort hardly lies within the oriental character. As wazir Yazuri himself amassed great wealth, far beyond what could possibly have come to him from the regular emoluments of his office: a certain amount of perquisites, of a kind which the western would be inclined to describe as bribery, is known and tolerated in oriental administration and Yazuri, a minister who must be regarded as a good and beneficent ruler in spite of this, was not the one to take a high ground of morality in such matters. He imprisoned the Patriarch Christodoulos whom he accused of persuading the Nubian king to withhold tribute, $\mathbf{a}$ charge which does not seem to have had any foundation; then laid heavy fines on the whole Coptic community, no less a sum than 7o, ooo dinars, and closed churches until none were left in use, and imprisoned the bishops, all it would appear in the attempt to make the Copts pay up the fine or, as Yazuri would no doubt have described it, to disgorge some part of their plunder filched from the public revenue. It does not seem that there was any sectarian motive or feeling in these measures, although they are sometimes made to figure as religious persecution.

In $45^{\circ}$ Yazuri died, poisoned by order of the Queen Mother with the consent of the Khalif. The ostensible charge was that he had been detected in treasonable correspondence with the court of Baghdad, but the real reason seems to have been that his inordinate wealth, which could only have been attained by defrauding the public revenue on a gigantic scale, had awakened jealousy and suspicion.

It is interesting to turn aside for a moment to the Persian poet Nasir-i-Khusraw, who visited Cairo in the years just preceding the ministry of Yazuri and who left a most graphic account of the wealth and splendour of the Fatimid court and the prosperity of Cairo even at that period of comparative disorder. In the eyes of this traveller, familiar with the most prosperous and cultured cities of Persia and 'Iraq, the magnificence of Cairo and its court seemed astonishing, and exactly the same impression was made years afterwards, after the 
Fatimids had long passed the zenith of their glory, on the Crusaders from the west. Under Fatimid rule, apparently, Cairo surpassed all the cities of the then known world in its luxury, magnificence, and wealth. As we have already noted ostentatious display was the besetting fault of the whole Fatimid dynasty, but this, it must be remembered, is usually popular in oriental circles. Nasir-i-Khusraw was a devout Isma'ilian and regarded Cairo as the metropolis of his religion and the Khalif as the true Imam, religious beliefs which he expresses freely in his works. He was a secretary under the government in Khurasan until he experienced a conversion to the religious life and, resigning his office, became first a pilgrim and then a da' $i$ of the Isma'ilian sect. In his best known work the Safarnama he describes how, after he had turned to religion, he set out for Mecca in 437 , and relates the experiences of his journey. He reached Mecca in 439 and returned thence to Damascus, then went to Jerusalem, and then by land to Cairo where he remained two or three years, and during his stay was initiated into the higher grades of the Isma'ilian fraternity. As his work was intended for general reading he is cautious in referring to the more intimate matters of religion, but makes it quite clear that he believes in the allegorical interpretation of the Qur'an, that he accepts the Fatimid Khalif as the true Imam, and adheres whole-heartedly to the doctrines of the Fatimite sect. He gives a most glowing description, not only of the splendours of the Cairene court, but of the extraordinary wealth and prosperity of the bazars and their merchants, and this at a time (circ. 440) which we generally regard as one of the less fortunate periods of Fatimid rule. It is particularly interesting to note his observations on the Egyptian army at the time when its factions were at the bottom of all the domestic troubles of Cairo. He estimates the whole army as about 215,000 men. Of the cavalry 35,000 came from North Africa, Berbers and Arabs, 50,000 were Arabs from the Hijaz, and 30,000 were of mixed composition. Of the infantry, where the racial elements are more significant, 20,000 were black troops raised in North Africa, 30,00o were Ethiopians by which we must understand Nubians, Sudanis, etc. Io,00o were Syrians, Turks and Kurds, 
30,0oo were slaves presumably from central Africa for the most part, and Io,ooo are described as the "palace guard," which seems to have been a kind of foreign legion of adventurers from various parts of Africa, Asia, and Europe. IVe shall have to return again to Nasir-i-Khusraw, for after leaving Cairo he became a $d a^{\prime} i$ of the Isma'ilians in western Asia, and indirectly played an important part in the formation of the offshoot of the Isma'ilians, which afterwards became notorious as the "Assassins,"

Yazuri's wazirate saw a great limitation of Fatimid control over North Africa, where in 443 Ifrikiya definitely repudiated the Shi'ite doctrines. At that time the ruler of Ifrikiva settled now at the town of Mahadiya which had replaced Kairawan, was Mu'izz al-Himyari as-Sanhaji, the hereditary chieftain of one of the more prominent Berber tribes, and more or less hereditary governor of If rikiya. Hakim had conferred on him robes of state with the title Sharaf ad-Dawla (" nobleness of the empire") in 407. Up to this time the Hanifite system of canon law had prevailed through North Africa, for the Shi'ite attempt to introduce the system ascribed to Ja'far as-Sadiq seems to have been a failure, but Mu'izz introduced the Malikite jurisprudence throughout his governorate; this, it will be remembered, was the system banned by the Khalif azZahir in Egypt, and by thus acting Mo'izz showed very plainly his entire disregard of the Fatimid who claimed to be his suzerain. Now, in 43.3, Mu'izz formally repudiated Fatimid authority, omitting the name of Mustansir from the khutba, and replacing it with the name of the 'Abbasid Khalif of Baghdad. At this Mustansir wrote: "Thou hast not trod in the steps of thy forefathers, showing us obedience and fidelity?"'-but Mu'izz replied: "My father and forefathers were kings in Maghrab before thy predecessors obtained possession of that country. Our family rendered them services not to be rewarded by any rank which thou canst give. IThen people attempted to degrade them, they exalted themselves by means of their swords." Thus the Fatimids lost what had been the earliest part of their dominions in Africa, although the loss was not without its benefit, for Ifrikiva had always been a course of trouble and of little real profit. 
The defection of Ifrikiya was not followed in all parts of North Africa. There were still devoted Shi'ites in those parts, and they revolted from Mo'izz when the Fatimid sent the Arab tribe of Hilal to win back the country. The Arabs succeeded in recovering Barqa and Tripoli, but were unable to advance further west. At the same time various independent states, for the most part professing to be Shi'ite, arose in Maghrab.

In $44^{8}$ the Turk, Tughril Beg, was recognised in Baghdad as the Sultan and lieutenant of the Thalif. The Saljuq Turks were strictly orthodox, and indeed at this time recognised themselves as the champions of orthodoxy. When, two years later, the general of the troops in Bagindad, a Turk named Arslan al-Basasiri, revolted against the Khalif al-Ka'im and expelled him from Baghdad, he put the seal on his revolt by causing the khutba to be said throughout Mesopotamia in the name of the Fatimid al-Mustansir, and sent him his protestation of allegiance. The expelled 'Abbasic Khalif took refuge with the Emir of the Arabs and stayed with him one year, and then the Saljuq Tughril Beg came to his relief, and having attacked and slain al-Basasiri, reinstated the 'Abbasid in Baghdad. The Khalif made his entry into the city exactly one year after his expulsion, so that Fatimid al-Mustansir had just one year's nominal recognition in Mesopotamia, but this cannot be seriously regarded as an extension of the Fatimid dominion.

The proclamation of the Fatimid Khalifate in Baghdad and the exile of the 'Abbasid Khalif from his capital raised unduly high expectations in Egypt. The more so as the official robe and jewelled turban of the Baghdad Khalif, as well as the iron lectern, were carried off to Cairo, and remained there until the fall of the Fatimids. A1-Mustansir was confident that these symbols would be soon followed by the "Abbasid in person, and laid out a large sum, stated to be no less than two million dinars, in preparing the second palace which stood facing his own dwelling across the great square in Kahira for the occupation, as he hoped, of his illustrious captive.

In fact, however, the Fatimid Khalifate had already passed its happiest hours and was rapidly approaching 
its decline. The Arabs still held Tripoli and Barqa as subjects of Egypt, but this was the western limit of Fatamid rule and the death of Anushtakin had practically ended its authority in Syria.

Just about this time, however, there was a temporary restoration of Fatimid authority in the Hijaz, and this not due to a rebel like al-Basasiri, but to the work of a devout and earnest Shi'ite. Abu 1-Hasan 'Ali b. Muhammad b. 'Ali as-Sulaihi was the son of a Qadi of Yemen, a strict and orthodox Sunni. The son, however, came under the influence of an Isma'ilian missionary named "Amir b. 'Abdullah az-Zawwahi who, concealing his Shi'ite opinions, was received into great favour by the Qadi, but in private intercourse with the son taught him the Fatimid system of canon law and the tawil or allegorical interpretation of the Qur'an. For fifteen years as-Sulaihi acted as guide to the Meccan pilgrims along the road between as-Sarat and Taif, then in 429 he broke out in revolt against the established government and, at the head of sixty followers, whom he bound by oath, seized upon Mount Mashar. Secretly he supported the Khalifate of Mustansir, but this he concealed for fear of Najah, the chieftain of the Tihama. In 452 he presented Najah with a beautiful female slave who, acting under his directions, poisoned $\mathrm{Najah}$ and then released from all need of concealment openly proclaimed the Fatimid Imamate. Three years later we find him the master of all Yemen, having his headquarters at Sana'a, and for nearly twenty years the khutba in the cities of Yemen, and for part of that time also in the holy cities of the Hijaz made mention of the name of the Khalif alMustansir.

After the death of Najah he offered to give the chieftainship of the Tihama to anyone who would pay him Ioo,ooo dinars of gold. The sum was at once paid by his wife on behalf of her brother Asaad b. Shihab. "Where didst thou get this, mistress?" asked asSulaih. "From God," she replied, "God is bounteous without measure to whom he will (Qur. ii. 208)." Perceiving that the money came from his own treasury as-Sulaihi smiled and took it saying, "Here is our money returned to us " (Qur. xii. 65).

In 473 he made the pilgrimage to Mecca, taking with 
him his wife and all the princes whom he thought at ail likely to revolt during his absence. Having appointed his son al-Malik al-Mukarram as his deputy at home he set out with 2,00o horsemen and encamped outside al-Mahjam. Whilst there he was sought out and found by Sa'id, the son of the poisoned Najah, who had been roving about the country but had managed to evade the soldiers of as-Sulaihi. At the very moment when Sa'id entered as-Sulaihi's tent 5, ooo horsemen were out in search of him. Entering his enemy's tent Sa'id at once cut off his head and then, escaping, went out and joined himself to the horsemen who were searching for him; he announced to them as-Sulaihi's death, declared who he was himself, claiming to be one of their own race and simply acting to avenge his father's death. At once the horsemen placed themselves under his command, and returning to the camp fell upon asSulaihi's guards and defeated them. As-Sulaihi's head was placed on the top of his own state umbrella and carried round to the chanting of the verse, " $\mathrm{O}$ God, possessor of all power, thou givest power to whom thou wilt, and from whom thou wilt thou takest it away. Thou raisest up whom thou wilt, and whom thou wilt thou dost abase. In thy hand is good; for thou art over all things potent", (Qur. iii. 25). Thus asSulaihi's kingdom came to an end and with it ceased the recognition of the Fatimid Khalif in Arabia (Ibn Khall. 5I2, etc.).

Thus, from time to time, Muntasir received temporary recognition in various unexpected quarters and seemed to bulk more prominently than any of the preceding Fatimid Khalifs in the history of Islam, but meanwhile his kingdom was on the decline and in Egypt was in evil condition, indeed the period $45^{\circ}$ to 466 shows the nadir of their authority in Egypt itself.

The death of Yazuri in 450 was a very serious loss as it once more liberated the factions and forces of disorder, the evil influence being the Turkish general Nasir ad-Dawla, the same who had succeeded Anushtakin in Syria. After the murder of Yazuri there were forty different wazirs in the space of nine years, many of these being put to death at the end of their term of office, although about this time the more humane practice came into force of appointing the deposed 
minister to some minor post, very often some provincial government, from which it was quite possible for him to rise to the wazirate again. None of these was a man of any great weight or marked personality, so that the Khalif fell entirely into the hands of mere court flatterers, altogether obscure and incompetent persons, and himself developed a childish and petulant attitude. He was especially annoyed at the frequent interference of the Queen Mother in the affairs of the state, but had not the strength or courage to check her.

The faction fights between the Turkish mercenaries and the negro troops became more constant and violent under this weak and incompetent rule. At length in $45+$ the Turks, led by Nasir ad-Dawla the Commanderin-Chief, drove the negro regiments out of Cairo and chased them to Upper Egypt where they were kept, although for some years they made regular attempts to recover their footing in Lower Egy pt. The victorious Turks dominated Cairo, held the successive wazirs in subjection, treated the Khalif with contempt, and used their power to deplete the treasury by increasing their pay to nearly twenty times its former figure. At last Nasir ad-Dawla's tyranny made him offensive even to his own officers, and gave the Khalif the opportunity of getting rid of him in 462 . Though deposed in Cairo he was able to hold his own in Alexandria where he had the support of the B. Qorra Arabs and the Lawata Berbers. Thus the Arab and Berber tribes under Nasir, helped by some of the Turkish mercenaries, were in command of Alexandria and a considerable portion of Lower Egypt, whilst the expelled negro troops were in possession of Upper Egypt, the Khalif's authority being limited to Cairo and its immediate vicinity. Added to this was the fact that beginning with $45^{8}$ there had been a series of bad Niles followed by a famine of seven years duration (459-465), whose later period was aggravated by Cairo being practically isolated by the rebel forces to the north and to the south, the Berbers in Lower Egypt deliberately aggravating the distress by ravaging the country, destroying the embankments and canals, and seeking every way to reduce the capital and the neighbouring districts by sheer starvation. In the city a house could be bought for 20 pounds of flour, an egg was sold for 
a dinar, a cake of bread for fifteen dinars, and even horses, mules, cats, and dogs were sold at high prices for food. In the Khalif's own stable where there had been 10,000 animals there were now only three thin horses, and his escort fainted from hunger as it accompanied him through the streets. Many great princes and ex-officials of the court gladly filled menial offices in the few houses where food was still found, and sought employment as grooms, sweepers, and attendants in the baths. Of all the Fatimids Mustansir had at one time enjoyed the largest revenues and in 442 he had inherited the almost incredible wealth of two aged ladies descended from his ancestor Mo'izz. But most of this had long since been plundered by the Turkish guard, and now he also was reduced to dire poverty. The Queen Mother and other ladies of the Khalif's family made good their escape and took refuge in Baghdad. At length the people of Cairo were reduced to feeding on human flesh, which was even sold publicly in the markets. Wayfarers were waylaid in the lonelier streets, or caught by hooks let down from the windows, and devoured. As an inevitable result of this protracted famine plague broke out, whole districts were absolutely denuded of population, and house after house lay empty.

Meanwhile the Turkish mercenaries had drained the treasury, the works of art and valuables of all sorts in the palace were sold to satisfy their demands; often they themselves were the purchasers at merely nominal prices and sold the articles again at a profit. Emeralds valued at 300,000 dinars were bought by one Turkish general for 500 dinars, and in one fortnight of the year 460 articles to the value of $30,000,000$ dinars were sold off to provide pay for the Turks. But this selling of the valuable collections accumulated in the palace was as nothing compared to the damage done wantonly by sheer mischief or unintentionally by carelessness. The precious library which had been rendered available to the public and was one of the objects for which many visited Cairo was scattered, the books were torn up, thrown away, or used to light fires.

At length, after the Queen and her daughters had left Cairo, the Turks began fighting amongst themselves. Nasir ad-Dawla attacked the city which was 
defended by the rival faction of the Turkish guard and, after burning part of Fustat and defeating the defenders, entered as a conqueror. When he reached the palace he found the Khalif lodged in rooms which had been stripped bare, waited on by only three slaves, and subsisting on two loaves which were sent him daily by the charitable daughters of Ibn Babshad the grammarian.

After this victory over the unhappy city Nasir adDawla became so over-bearing and tyrannical in his conduct that he provoked even his own followers, and so at length he was assassinated in 466. But this only left the city in a worse condition than ever, for it was now at the mercy of the various Turkish factions which behaved no better than troops of brigands.

At this desperate juncture al-Mustansir was roused to action and wrote to the Armenian Badr al-Jamali, who had once been purchased as a slave by Ibn 'Ammar and was now acting as governor of Tyre, begging him to come to the rescue. Badr replied that he would do so if he were allowed to bring his own army with him and were given a free hand." This was granted, and soon Badr was on his way. With courage quickened by the approach of rescue the Khalif ventured to arrest Ildeguz, the Turkish governor of Cairo, and thus put some check on the military tyranny. At his arrival Badr was well received by the Turkish mercenaries who had no idea that he had been invited by the Khalif. His first act was to invite the Turkish leaders to a conference: each of his own chief officers was told off to deal with one of these leaders and, at a given signal, each slaughtered the man who had been designated. Badr then set himself to restore order in Cairo, and this he did efficiently but with the severity rendered necessary by the desperate condition of the city, and thus re-established the Khalif as master. The grateful prince could not do too much to show his appreciation of these services, and $\mathrm{Badr}$ was created wazir of the sword and of the pen, i.e., chief minister of affairs military and civil, Chief Qadi and Chief $D a^{6} i$. After reducing Cairo to complete order he proceeded with his troops through Lower Egypt, putting down brigandage and disorder until he reached Alexandria where he had some resistance to overcome, but in due 
course that also was reduced. The settlement of Cairo and Lower Egypt occupied the greater part of 467 : then in 468 he proceeded to Upper Egypt and succeeded in disbanding the black troops which held out there, and reduced those parts also to good order. Thus, once more, Egypt was under an efficient and firm government. It is true that his efforts were greatly assisted by the fact that the year 466 saw an exceptionally good Nile, so that prosperity and abundance .once more reigned through the land. It is interesting to note that the Khalif set himself to the formation of a new library at Cairo as one of his first tasks; it helps us to realize that the Shi'ites were then as always the friends of learning.

Meanwhile difficult problems had arisen in Syria. The Saljuq Turks, who were now dominant in Baghdad, were fanatically orthodox and set themselves deliberately to root out the Fatimids from Islam. In $46 \mathrm{r}$, during the period of disorder in Egypt, they had gained possession of Jerusalem, and in 466 they took Damascus which never again acknowledged a Fatimid ruler. The Saljuq general Atsiz then planned an expedition against Egypt itself, and as this threat came just at the moment when Badr was setting himself to the task of restoring order in Egypt he was not in a position to attempt an expedition against the Saljuk Turks. Ships were made ready to remove the court to Alexandria, and messengers were sent out to attempt to bribe the Turkish general to retire. In fact Atsiz was not well supported and felt himself not in a position to press forward, so that this danger was averted. As soon as Badr had reduced Lower Egypt he sent an expedition to recover Palestine and Syria, and his army was able to gain possession of Jerusalem, where Atsiz had been governor since 468 . Hard pressed by the Egyptians Atsiz appealed for help to the Saljuq general Tutush who had entered Syria with large reinforcements, and at length evacuated from Jerusalem and marched out to join with him. He met Tutush at Damascus, but the Saljuq Commander-in-Chief severely rebuked Atsiz for quitting Jerusalem and arrested and executed him (A.H. 47I), and then himself took possession of the whole of Syria. In 478 Tutush, now 'Abbasid viceroy in Syria took Aleppo, but soon after 
this he found himself opposed by his nephew Barkyaruk, with whom he was compelled to wage war for some time until he was slain in battle by his nephew's forces in 488. Taking advantage of this civil war Badr made another attempt upon Damascus, but this was unsuccessful, although the Egyptians recovered Tyre and Akka. Shortly after this success, in $48 \pi$, , Badr died and was succeeded as wazir by his son Abu l-Kasim Shahanshah, commonly known as al-Afdal; and the wazir's death was soon followed by that of the Khalif Mustansir.

The rule of Badr was especially associated with a great development of building, and especially with the construction of new walls and gates round Cairo. In this work Badr employed Syrian architects who introduced Byzantine styles of architecture and of fortification, and made a greater use of stone in place of the brick which predominated in the older constructions. The existing gates known respectively as the Bab anNasr, the Bab al-Futuh, and the Bab az-Zuwayla, are specimens of Badr's work, and show an almost purely Byzantine style in marked contrast to the native Egyptian work, and so the outpost tower called by the unintelligible name of the Burg adh-Dhiffir. All these formed part of the south boundary of the ancient Kahira, but are now included within the area of the modern city. To the same period belongs the restoration of the Nilometer in the island of Roda (A.H. 485).

In 483 Badr made a new assessment and return of taxation for Egypt and Syria. Under his rule the annual revenue had risen from 2,000,000 dinars to $3,100,000$, and peace and prosperity reigned in all the land of Egypt, though war prevailed in Syria, the mark of the first waves of Saljuq invasion.

Before closing the narrative of the reign of Mustansir we must take note of a visit to Egypt paid by a Persian missionary in $47 \mathrm{I}$, closely connected with the visit of Nasir-i-Khusraw some years before, and important in its bearing upon events which followed soon after Mustansir's death.

This Persian missionary, Hasan-i-Sabbah by name, was born in Qum whither his father had removed from Kufa. Like his father he was a Shi 'ite of the "Twelver" sect, but came under the influence of Nasir-i-Khusraw 
who was an active propagandist, although at the time Isma'ilian doctrines were not making much progress in Asia. After considerable hestitation he became a proselyte of the Isma'ilians and took the oath of allegiance to the Fatimid Khalif. In 464 he came under the notice of the overseer of the mission work in the district (bahr, literally, "sea ") of Isfahan, and was advised by him to make a pilgrimage to Egypt. After spending two years as assistant to the overseer of Isfahan he set out in $47 \mathrm{I}$ and reached Cairo in 467 where he was well received by the Chief $D a^{\prime} i$ and other leading persons, but was not allowed to have an interview with the Khalif. At the time, it appears, the court was divided into two factions over the question of the succession, the one party holding to the Khalif's elder son Nizar, the other to a younger son named Mustali. In one place Nasir-i-Khusraw says that the Khalif told him that his elder son Nizar was to be his heir, and the succession of the older son would be in accordance with the doctrines of the sect as already proved by their adherence to Isma'il, the son of Ja'far as-Sadiq. But Badr and the chief officials were on the side of the younger son Mustali, and it was probably the knowledge that the Persian visitor was opposed to them on this question which stood in the way of a personal interview with Mustansir. After eighteen months in Egypt Hasan-i-Sabbah was forced to leave because, according to his own statement, he had provoked the suspicion of Badr. So in 472 he embarked at Alexandria. His ship was wrecked on the coast of Syria, and after much wandering the at length made his way overland to Isfahan where he arrived in 473. At once he commenced propaganda amongst the Isma'ilians in favour of Nizar as the chosen heir to the Imamate. In this work he was successful, and in 483 he obtained possession of the castle of Alamut (" the eagle's teaching ") which he made the headquarters of his branch of the Isma'ilian sect. As supporters of the claims of Nizar the members of this branch were known as "Nizarites," but later the name of "Assassins" became their commoner designation. This term represents the Arabic Hashishi, that is to say, user of Indian hemp or the "Faqir's herb" (cannabis Indica), as this was used as a means of intoxication and exaltation to 
arouse the members of the sect charged with peculiarly difficult duties. In a later chapter (cf. pp. 213, etc.) we shall see that these duties, the acts which are now especially associated with the term assassin, were performed by quite subordinate members of the sect; but these members entrusted with the performance of deeds of violence and daring were prepared by being worked up into a frenzy by the use of this drug whose peculiar influences are well known in the east. From 473 to the date of Mustansir's death in 487 these "Assassins" were occupied in preaching the claims of the prince Nizar to the Imamate, but they did not definitely separate from the Isma'ilian body or from their allegiance to the Fatimid Khalif until, at Mustansir's death, the elder son Nizar was formally excluded from the succession, so that our further consideration of the sect is best deferred to the next reign. A large literature exists on the history of the Assassins. The most important authority is the "Adventures of our master" (i.e., of Hasan-i-Sabbah), a lost work included amongst the books in the great library at Alamut and examined by 'Ata Malik Juwayni before it was burned with other heretical works, and from it he makes important citations.

The longest Khalifate of Muslim history closed with the death of Mustansir on the r 8 th of Dhu 1-Hijja, 487 (A.D. I094), and at once the wazir al-Afdal announced the accession of the younger son al-Mustali. 


\section{XIII}

\section{THE NINTH FATIMID KHALIF, AL-MUSTALI (A.H. $487-495=$ A.D. $1094-\mathrm{IIOI}$ )}

As soon as al-Mustansir was dead the wazir al-Afdal al-Juyush entered the palace and placed Abu 1-Kasim Ahmad al-Mustali, a youth of eighteen years of age and the youngest son of the late Khalif on the throne. At the same time he sent for the other sons of Mustansir who were near at hand, Nizar the eldest son, and his brothers 'Abdullah and Isma'il, bidding them come quickly. As soon as they entered the room where the wazir awaited them and saw their youngest brother enthroned they were filled with indignation, and when al-Afdal bade them do homage to Mustali as the new Khalif, Nizar burst out, "I would rather be cut in pieces than do homage to one younger than myself, and moreover I possess a document in the handwriting of my father by which he names me successor, and I shall go and bring it." At this he went out, presumably to get the document, but as he did not return the wazir sent after him, and it was found that he had left the city. Very soon afterwards he appeared at Alexandria, supported by his brother 'Abdullah and an emir named Ibn Massal, and there he assumed the title of Khalif with the surname of al-Mustafa li-dinillah (" the chosen for God's religion'), and received the oath of allegiance from the Alexandrians. He promised Nasir ad-Dawla Iftikin, the Turkish governor of Alexandria, that he should be wazir. As we have already seen, there was a party ready to support Nizar even before Mustansir's death, and his claims seemed to have fair prospects of success. No doubt we may say that the sectarian supporters of the Fatimid Imamate were with him, whilst al-Afdal headed the secularist party: but there would, no doubt, be many aggrieved with the existing administration, and even perhaps remnants of those whom al-Afdal's father had suppressed with such severity, who were ready to throw in their lot with the opposition to the wazir's nominee in Cairo. 
In 488 al-Afdal found it necessary to take the field against Nizar and his followers, but suffered a sharp repulse in the first engagement. Encouraged by this the Nizarites laid waste the country north of Cairo. Again al-Afdal prepared his forces and marched this time to Alexandria and laid siege to it. During this siege Ibn Massal had a dream in which he seemed to be riding on horseback and al-Afdal was following him on foot. He consulted an astrologer as to the meaning of this dream, and was informed that it signified the ultimate success of al-Afdal, for those who walk the earth are those who will possess it. Ibn Massal took this very seriously and thought it prudent to leave Nizar's party, so he departed and retired to Lukk near Barqa. This defection marked the turning point of Nizar's career for, after losing Ibn Massal and his men, his fortunes gradually declined. Convinced that resistance could not endure for long he sent out and asked al-Afdal if he would spare his life if he submitted. Receiving a favourable answer the gates of Alexandria were opened to the wazir who took possession of the city and, after putting an end to all resistance, returned to Cairo with Nizar and 'Abdullah. Nizar's subsequent life is totally unknown. He was either imprisoned in absolute secrecy, or put to death: stories were told of both these ends, but nothing was ever known for certain. A certain Muhammad afterwards claimed to be Nizar's son, and had a following in Yemen : he was brought to Cairo and crucified in 523 . In all probability he was an imposter.

The suppression of Nizar and his partisans meant the triumph of al-Afdal, and during the rest of Mustali's reign the Khalif was entirely without authority in the state, and came out only as required at public functions.

The suppression of Nizar involved a definite separation between the Fatimids of Cairo and their court on the one side and the Asiatic adherents of Nizar's Imamate on the other, and so from 488 onwards the Assassins formed a distinct sect, as much opposed to the Fatimids and their followers as to the orthodox Muslims. The founder, Hasan-i-Sabbah, had now fully organised that sect on lines which were in general outline imitated from the traditional system of the Isma'ilians, but differed in detail. There were grades 
and successive stages of initiation, and the real beliefs of the higher grades were of the same pantheisticagnostic type as in the Isma'ilian body, and similarly the members of those upper grades were keen students of the science and philosophy which had been derived from Hellenistic tradition. When the headquarters of the sect at Alamut were finally taken they were found to contain a vast library as well as an observatory and a collection of scientific instruments. In fact we may say with confidence that the Assassins represent the highest level of scholarship and research in contemporary Asiatic Islam, if we can indeed regard them as within the Islamic fold; an island of culture and learning in the midst of reactionary orthodoxy and actual ignorance, the result of the submerging of Asiatic Islam beneath the flood of Turkish invasion. Far away in the west a purer culture was beginning to dawn in Muslim Spain, but in Asia philosophy and science were being rapidly obscured by the reactionary flood.

As organised by Hasan-i-Sabbah the Assassins appear in six grades. The highest of these was filled by the "Chief Da'i" who recognised the Imam alone as superior on earth. So long as Mustansir lived he was regarded as the true Imam; after his death Nizar was his successor, and later on we find the Chief Da'i claiming descent from Nizar, but this was as yet in the future. It was the same development as that which we have already observed in the history of the Shi'ite sect founded by 'Abdullah b. Maymun. Amongst outsiders the Chief $\mathrm{Da}^{\text {' }} \mathrm{i}$ commonly went by the name of "Sheikh of the mountain," i.e., of the mountain stronghold of Alamut which formed the headquarters of the sect, and this is reproduced as " the old man of the mountain" in the records of the Crusaders. Under the Chief Da'i were the "Senior Missionaries" (da'ii-kabir), each supervising a diocese or bahr (" sea "), and under these were the ordinary missionaries. Thus far the organization merely reproduced that already prevalent in the Isma'ilian propaganda. Beneath the missionaries were the ordinary members in two main grades known respectively as "companions" (rafiq) and "adherents" (lasiq), the former more fully initiated in the batimite or allegorical interpretations of 
doctrine than the latter. The sixth grade, theoretically the lowest, was peculiar to the Assassin sect, and consisted of " devoted ones" (fida'i) who do not seem to have been initiated, but were bound to a blind and unquestioning obedience which has its parallel in the discipline of the various darwish orders, but was here carried to exceptional extremes. These fida is were carefully trained and were especially practised in the use of various forms of disguise, after all only a more perfect refinement of the methods originally evolved by the Hashimite missionaries; but these were not disguised for the purpose of acting more efficiently as missionaries and for penetrating different communities as teachers, but solely for the purpose of carrying out the specific orders of the Chief $\mathrm{Da}^{\prime} \mathrm{i}$, and thus formed a most formidable branch of what soon became an exceptionally powerful secret society. In many cases the acts entrusted to the fida $a^{\prime}$ is were acts of murder, and it is from this that the name of "assassin" has received its peculiar meaning in most of the languages of Western Europe. The fida $i$, trained to the use of disguise, sometimes as a servant, or as a merchant, or darwish, or as a Christian monk, was able to penetrate into almost any society and to strike down suddenly the victim marked out; and counted it a triumphant success if this act involved his own death as well. A deliberate effort was made to surround the sect with an atmosphere of terror; a Muslim prince would be struck down whilst he was acting as leader at prayer, or a Crusading knight as he was attending high mass at the head of his troops, or if there was not actual murder, a leader might wake up in his tent to find a message from the Assassins pinned by a dagger to the ground beside his couch, or a doctor of the law would find a similar message between the pages of the text book from which he was lecturing. All this was developed more elaborately as time went on, but already in the days of Mustali the sect had rendered itself prominent by getting rid of some leading men whom it regarded as its enemies, such as in 485 Nidhamu 1-Mulk the great wazir of the Saljuq sultans, in 49r 'Abdu r-Rahman as-Samayrami the wazir of Barkiyaruq's mother, and in 494 Unru Bulka, the rival of Nidhamu 1-Mulk and the emir of greater influence in 
Isfahan. The higher members of the sect were domiciled at Alamut, or in some one or other of the various mountain fortresses they secured in Northern Persia and afterwards in Syria, but adherents were found everywhere scattered through western Asia. In its development the sect of Assassins was almost entirely Asiatic, but as professed adherents of Nizar the eldest son of Mustansir, the Assassins were, at least nominally, of Egyptian origin.

So far the danger most threatening to the Fatimids had been the advance of the Saljuq Turks, pledged to the destruction of the Isma'ilian heresy, from the east : but in the fourth year of Mustali's reign a new danger appeared. This was the appearance of the Franks embarked on the First Crusade, who reached Syria in the year 490, when the Saljuq influence was already on the decline. The great Saljuq leader Tutush had died in the preceding year, and his two sons at once became rivals, the one, Duqaq, established at Damascus, the other, Rudwan, at Aleppo. Rudwan was anxious to obtain Fatimid assistance and inserted Mustali's name in the khutba, but the Fatimid state regarded the Saljuqs with dread and suspicion, and was disposed to welcome the Franks as possible allies against the Turks. Jerusalem remained in Saljuq hands under the control of the sons of Ortuk b. Aksab who had governed in the name of Tutush, and they formed an outpost of the Saljuq empire which the Fatimid government regarded as its chief enemy in the east.

The Crusaders professed to be the champions of the Christian religion and declared their aim as being the deliverance of the sacred sites from the occupation of the Muslims. Before reaching Syria, however, they had made it plain that this was not to be understood in a literal sense, for they had shown marked hostility towards the Greek Church, and throughout the whole of their career they were the uncompromising enemies of all the eastern churches. No doubt this can be partly explained by a total lack of understanding or sympathy towards religious bodies whose general customs and external organisation, and more particularly whose liturgy, differed so markedly from the forms developed in the west; but the fact remains that their fellow Christians in the east soon came to regard the 
Crusaders with as much dislike as the Muslims. This antagonism towards the Greek and eastern churches generally was fully defined before their arrival in Syria. But in fact they were not even the champions of Latin Christianity. Some, no doubt, were sincere in their desire to rescue the Holy Land from non-Christian occupation, but for the most part they were adventurers desirous of carving out principalities in lands which they were well aware were much richer and more prosperous than their own countries in the west. From their own point of view the time at which this Crusade arrived was exceptionally promising: the Saljuq power was broken and there was a temporary lull in the migration of the virile and warlike Turkish races westwards, whilst the Muslim community was divided between 'Abbasids and Fatimids beyond the possibility of united resistance. Twenty years earlier, or fifty years later they would certainly not have been able to establish themselves in Palestine, but just at the moment circumstances were favourable.

Arriving in Syria in A.H. 490 the Crusaders under Baldwin (or Bardawil as he appears in the Arabic writers) took the city of Edessa and then proceeded to lay seige to Antioch which fell into their hands on the I6th of Rajab 49I (20th June, I098). News of their arrival and first successes had early reached Egypt, and al-Afdal prepared to welcome them as likely auxiliaries against the Turks : it seemed fully possible that the Franks and Fatimids might divide Western Asia between them, and such indeed would have been feasible. Under this impression al-Afdal sent an army into Palestine and wrested Jerusalem from Sokman the son of Ortuk, who held it as a part of the Saljuq empire, at the same time sending forward an embassy to the Franks welcoming them and asking to make an alliance with them. The Franks absolutely rejected these proposals and declined to accept any friendly overtures from Muslims. Very soon they proceeded to attack Jerusalem, and in the month of Shaban, 492, took it, plundering the mosques, slaughtering the Muslim population, and showing themselves hostile to orthodox and Shi'ite alike. This disillusioned al-Afdal and made it clear to him that it was impossible to expect any sort of alliance with the new-comers. After 
taking Jerusalem and expelling the Fatimid government the Franks elected Godfrey king of Jerusalem, a rank which he held until the following year, and during this time he did his best to introduce western customs and jurisprudence in the city as well as the Latin rite in the churches.

In the following year (493) the Franks attacked the Egyptian army before Ascalon, which now remained the only important possession of the Fatimids in Palestine. Before the battle the wazir sent an envoy with a flag of truce, but this the Franks disregarded and made an assault upon those who, according to the customary usages of war, should have been sacred. In the ordinary way such attacks made in disregard of a flag of truce, reported in practically every war, ought not to be treated too seriously by the historian : it is almost impossible, even in the best disciplined army, to make sure that no abuse of this kind shall ever occur, but in the case of the Crusaders there seems to have been a deliberate intention to treat the Muslims as outside the ordinary conventions which were more or less observed amongst Christian nations: although it must be remembered that we are dealing with times before the rise of chivalry and the humaner attitude which characterised mediaeval warfare, all more fully developed after contact with the Muslims who did much to refine Frankish manners and usages; and, moreover, the very mixed multitude loosely held together in the Crusading ranks was undisciplined even beyond the wont of those days. In the succeeding engagement the Franks defeated al-Afdal and his forces, and he was compelled to embark for Egypt. Ascalon, however, was not taken as the citizens, alarmed by the recent savagery of the Franks in Jerusalem and perceiving that they were, for the most part, simply out for booty, bribed them to leave the city alone.

Two years later (495) the Franks gained another victory over the Egyptians near Jaffa and began seriously to consider the prospect of invading Egypt.

At this juncture al-Mustali died. At the moment, fortunately, the wazir al-Afdal was in Egypt, and on the day of his death proclaimed his son al-Amir Khalif in his place. 


\section{XIV}

\section{THE TENTH FATIMID KHALIF, AL-AMIR (A.H. $495-524=$ IIOI-II3I A.D.)}

At Mustali's death al-Afdal at once proclaimed Abu "Ali al-Mansur al-Amir bi-ahkami-llah (" the ruler by the decress of God"), then only in his fifth year, as Khalif, retaining the government in his own hands as had now become the established custom at the Fatimid court. Al-Afdal was an able and efficient ruler, whilst the young Khalif was of the type so common in oriental courts, a mere votary of pleasure and an idler. The wazir restrained the indulgence of his tastes and kept him closely confined in the palace. Al-Amir does not seem to have been at all aggrieved at being excluded from the government, but he certainly chafed at the restrictions which the wazir considered suitable to apply to his pleasures.

The centre of interest still lies in the Crusaders who had now established a firm hold in Palestine and were threatening Egypt. In 497 they took possession of Akka (Acre), and this increased the anxiety felt in the Fatimid court. In the same vear al-Afdal sent his son in command of an army to Palestine, and he was successful in inflicting a severe defeat on the Franks: many were put to flight, and Baldwin, who had succeeded Godfrey as king of Jerusalem, was compelled to hide in a haystack. The Egyptians then advanced and took Ramla and, after slaying a large number of the vanquished, sent three hundred knights prisoners to Egypt. Later in the year both sides were re-inforced, the Egyptians receiving an accession of four thousand cavalry as well as the support of a fleet, but no decisive step was taken and no progress inade on either side. At this time nearly all Palestine was in the hands of the Franks save the coast towns, and the struggle 
centered round Ramla. The Fatimids had the advantage of an alliance with Tughtegin, the Saljuq governor of Damascus, for the Turks had at last perceived that it was necessary for all Muslim powers to unite against those who had proved to be a common enemy. A battle took place between Ascalon and Jaffa, but without any important result.

Nothing of marked importance took place during the next three years, but in 502 the Franks succeeded in taking the important coast town of Tripolis on Monday, the I Ith of Dhu 1-Hijja. When they entered the town they plundered and slaughtered indiscriminately and seized many of the inhabitants for slaves; they destroyed the library of the college and tortured their prisoners in a barbarous manner. The Egyptian wazir had sent an army to the relief of the town, but it arrived too late to be of any service.

After the fall of Tripolis the Muslim forces centered at Tyre. In the following year (503) the Franks took Bairut, and in the year after Sidon, so that the Fatimid possessions were reduced to a precarious hold on Ramla.

Thus affairs stayed for some six years, then in 5 II Baldwin attempted the invasion of Egypt. He took Farama, burning the mosques, houses, and suburbs, and then advanced to Tinnis. Near this town he was taken ill, and shortly afterwards died at al-Arish. At his death the projected invasion was abandoned and the Frankish army retired, bearing with it the king of Jerusalem's body which was ultimately buried in the Church of the Resurrection.

Egypt had practically lost all hold upon Palestine, but yet the threatening horde of Franks was held off from Egypt itself, and this check was in no small degree creditable to the wazir al-Afdal, who meanwhile maintained a firm though not absolutely pure government at home. But gradually the Khalif became more and more restive under the severe tutelage of his wazir, and always there were intrigues of the aggrieved and the ambitions to urge him on, as well as the ever present influence of the harim which, in almost all oriental countries, is the centre of intrigues against the established powers. In 515 the Khalif began to plot definitely against his wazir, and one day as al-Afdal rode out towards the Nile he was attacked and severely 
wounded, so that he was carried home to die. The Khalif visited him on his death-bed and expressed great sympathy and regret for the accident which had befallen him, an accident whose real nature was perfectly well known to both : as soon as the wazir breathed his last the Khalif commenced plundering his house which was the depository of enormous wealth, and this occupied him forty days (Ibn Khall. i. 6r4, cf. Jamal ad-Din).

After al-Afdal's death al-Amir appointed Muhammad b. Abi Shujaa b. al-Bataihi al-Ma'mun as wazir. This new officer was a capable financier but harsh and tyrannical, and restrained the Khalif more rigorously than his predecessor had done. He was the builder of the "grey mosque" (Jami' al-Akmar), so called from its being one of the earliest buildings in which stone was used almost exclusively, and completed the " Mosque of the Elephant" (Jami" al-Fil) which had been commenced by al-Afdal in 498. He held office until 5 I 8 when he was arrested and his property confiscated. Three years later, in $52 \mathrm{r}$, he and five of his brothers, as well as the pretender who claimed to be Nizar's son, were put to death.

After the fall of Ibn al-Bataihi the Khalif determined to act as his own wazir, and in this was assisted by the Christian monk Abu Najah b. Kanna, who undertook the department of finance. The monk's method was to farm out the taxes to Christian collectors for a net sum of roo,ooo dinars, which he paid in to the treasury. But Abu Najah made himself extremely offensive by his arrogant airs and by being the scape-goat of the harsh exactions of the collectors, the inevitable result of this system, and after a brief try the Khalif was persuaded to depose him, and he was flogged to death. Al-Amir continued, however, to act as his own wazir until his death in 524, and this made his office universally detested and justifies the custom of appointing a wazir or deputy on whom the odium of the harsher details of the executive should lie, and against whom there might be, at least in theory, an appeal to the throne. Indeed, during these years 5 I9 to 524 the Khalif seems to have been more heartily hated than any other of his dynasty before or after. At length the end came in 524 by the hands of Isma'ilian Assassins who 
had undertaken the duty of ridding the country of the tyrant. On Tuesday, the 3rd of Dhu 1-Qa'dah, the Khalif proceeded to Fustat and thence to the island of Roda, where he had built a pleasure house for a favourite Baidawi concubirie. "Some persons who had plotted his death were lying there concealed with their arms ready; it being agreed among them that they should kill him as he was going up the lane through which he had to pass in order to reach the top of the hill. As he was going by them, they sprang out and fell upon him with their swords. He had then crossed the bridge and had no other escort than a few pages, courtiers, and attendants. They bore him in a boat across the Nile, and brought him still living into Cairo. The same night he was taken to the castle and there he died, leaving no posterity .... al-Amir's conduct was detestable: oppressed the people, seized on their wealth and shed their blood: he committed with pleasure every excess which should be avoided, and regarded forbidden enjoyment as the sweetest. The people were delighted at his death " (Ibn Khall. ii. 457 ).

During the latter part of al-Amir's reign the Franks continued to consolidate their kingdom in Palestine. On Monday, the 22nd of Jumada II. 5 r8, they took Tyre, and only Ascalon remained to the Fatimids of their former possessions in Asia. About this time the Franks began to strike their own coinage, after issuing coins in the name of the Fatimid Khalif for three years. 


\section{XV}

\section{THE ELEVENTH FATIMID KHALIF, AL-HAFIZ (A.H. $524-544=$ A.D. II $3 \mathrm{I}-\mathrm{I} 149$.}

THE Khalif al-Amir left no son, but at the time of his death one of his wives was pregnant, and it was possible that she might give birth to an heir. Under these circumstances Abu 1-Maymun 'Abdu 1-Hamid alHafiz li-dini-llah (" the guardian of the religion of God "), son of Muhammad, one of the brothers of Mustali, and consequently cousin to the late Khalif, was declared regent, and as such received the oath of allegiance from the citizens of Cairo on the very day of al-Amir's murder, and on the same day the wazir Abu 'Ali Ahmad, son of al-Afdal, received the oath of allegiance from the troops. The regent al-Hafiz expressed his confidence that the child about to be borne to the deceased Khalif would be a son, "No Imam of this family," he said, "dies without leaving a male child to whom he transmits the Imamate by special declaration" (Ibn Khall. 430). Although the late Khalif's cousin was thus declared formal regent the wazir Ahmad put him in confinement and took the whole power into his own hands, and this received the ready acquiescence of the court and of the troops and people, for everyone regarded the late experiment of the Khalif acting as his own wazir as disastrous. The new wazir ruled justly and well, and restored to each the property which had been confiscated by al-Amir, so that as a ruler he was greatly esteemed.

In other respects, however, his conduct throws a strange light on the conditions prevailing in the Fatimid state at this period. The Fatimids claimed to be not only rulers of Egypt, but the legitimate Khalifs in true descent from the Prophet, and also Imams divinely appointed as guides and teachers of 
Islam. The whole Fatimid state was bound up with this religious theory, although it was one which did not command the sympathy of the bulk of the subject population, and a distinct tendency had more than once appeared to discard it for frankly secular claims. Under the wazir Ahmad this theory on which the Fatimid claim rested was formally discarded by the government. Ahmad himself was a Shi'ite, but of the sect of the "Twelvers" and so a follower, not of the Fatimid Imam under whom he held office, but of the hidden and unrevealed Imam who, under the name of Muhammad al-Muntazir, had disappeared in 26o. For the present, therefore, the Friday prayer in the mosques was offered for the invisible "al-Ka'im," and his name appeared on the coinage. To us such a condition seems almost incredible, even though during the time the titular head was merely regent and not fully recognised as Khalif. When al-Amir's wife was delivered her child was a daughter, but for all that al-Hafiz remained simply regent until 526 .

Dissatisfied with his dubious position and the restrictions imposed by the wazir Hafiz plotted against him, and Ahmad was assissinated in the "Great Garden " as he was on his way to play polo on the 15th of Muharram 526 (Dec., II3I). At his death Hafiz received the oath of allegiance as Khalif, and was acclaimed by his bodyguard, the "Young Guard," although his reign is usually dated from the date of his cousin's death. At this time al-Hafiz was fifty-seven years of age.

$\mathrm{He}$ appointed as wazir an Armenian named Yanis who had been a slave of al-Afdal, one of the Armenian mercenaries whom he had brought from Syria. Yanis turned out to be a severe and hard ruler, and in the following year he was poisoned by the Khalif's order. In spite of the warning of al-Amir's reign al-Hafiz then resolved to act as his own wazir, and in this he did well and was generally regarded with respect and attachment. His court was, however, divided into factions as the result of quarrels about the heirship between his two sons Hasan and Fa'iz, each supported by one of the two great bodies of negro mercenaries, the elder Hasan by the Rayhaniya regiment, the younger by the Juyushiya. At length these quarrels 
resulted in open warfare, and the victorious Juyushiya to the number of 10,000 assembled before the royal palace and demanded the head of the prince Hasan. The Khalif was not in a position to refuse this demand and sent for one of the court physicians, a Jew named Abu Mansur, and asked him to poison Hasan, but the Jew prudently declined the dangerous task. He then sent for a Christian plysician named Ibn Kirfa who performed it, and the dead prince's head was given to the rebels. But the Khalif never forgave Ibn Kirfa for what he had done, and before long an excuse was found to imprison the Christian physician, and in due course he was executed.

After their successful revolt the troops elected as wazir the Armenian Bahram. But he very soon made himself unpopular by showing marked favouritism towards his fellow countrymen who, for the most part, had entered the country in the company of the Armenian Badr al-Jamali. As a result he was deposed and most of the Armenians expelled from the country. Bahram ended his life as a monk.

In 532 Rudwan was appointed wazir and was the first official in Egypt to assume the title of "king." But he held office only for a few months, and in 534 was cast into prison.

Meanwhile the Franks had met with several checks. The Turks under Zengi defeated them at Atharib in 525 , and in 539 took Edessa from them. Thus the Franks began to be threatened from the north-east, and their opponents were consciously making plans for their final subjugation or expulsion. In 541 Zengi died and was succeeded by his son Nur ad-Din, who becomes the decisive factor in the affairs of western Asia and Egypt within the course of the next few years. At this time the Franks were distinctly on the decline, and the hopes built on the foundation of Jerusalem and other Latin kingdoms in Palestine and Syria were not being realised. The West began to feel that the First Crusade had failed in its effort, and so the Second Crusade, mainly the work of St. Bernard whose aims and intentions were above question, set out in 542 and attacked Damascus in the following year, the Crusaders then marching on Jerusalem. But the Second Crusade 
was an immediate and marked failure. Conditions were greatly changed from what they had been when the former Crusade arrived: there was now a strong Turkish power in Syria, and this was inclined and prepared to be aggressive. The Second Crusade was necessarily a failure. The only important result of Frankish invasion was the kingdom of Jerusalem which had been the work of the First Crusade.

At this period of Egyptian history we are able to avail ourselves of the very interesting record which Osama has left of his own experiences in Syria and Egypt, a record which has been rendered accessible in the French translation of Derenbourg (Vie d'Ousama Paris, I 886-93). Osama left Damascus in 538 and went to Cairo, where he was well received by al-Hafiz, who gave him a robe of honour and a house and other gifts. So long as Hafiz ruled Osama took no part in the public affairs of Egypt, but has left observations upon the course of events, but in the next reign he comes forward prominently as an adviser, and usually as an adviser of evil.

When the ex-wazir Rudwan had been ten years in prison he contrived to bore his way out through the prison walls by the help, it is said, of a rusty nail, and, joined by many of his friends, went to Gizeh intending to seize the wazirate by force. There was a great ferment in Cairo; many persons went out to join themselves with him, whilst the Khalif's guards prepared for defence. At the head of a large band of followers he forced his way across the Nile, defeated the Khalif's army, and marched into Cairo where he made his headquarters in the Grey Mosque. There he was joined by many of the emirs who brought supplies of men, arms, and money. The Khalif assembled his negro troops treated them to wine and then, in a half intoxicated state, they marched out and demanded the head of Rudwan. A great tumult ensued in which the emirs, frightened by the apparent ferocity of the negro guard, left Rudwan, and his supporters were scattered. Rudwan himself was alarmed and went out of the mosque intending to escape, but his horse which should have been at the gate was missing. A young guard offered his horse, and as the ex-wazir approached to avail himself of this offer, he cut him down. Very 
soon the negroes came up and finished him, then " the people of Misr share the morsels of his flesh which they eat to give themselves courage" (Derenburg: Vie d'Ousama, p. 212).

This took place in 543 and led to a period of general disorder, for the negro troops called out by the Khalif soon passed beyond his control, the streets became unsafe, and faction fights between the Rayhamites who were loyal to the Khalif and the Juyushites, Alexandrians, and Farhites once more broke out just as sixteen years before. Again the Juyushites were victorious, greatly to the annoyance of al-Hafiz who determined to revenge himself upon them. But this resolve he was not able to carry out as he died in 544 .

Al-Hafiz was an old man at the time of his decease, fully seventy-six years, and for some time had been in failing health suffering from colic. It is said that Shirmah the Daylamite, or else Musa an-Nasran, made for him a drum of seven metals, each welded at the moment when the appropriate planet was in the ascendant, and that this drum when beaten relieved the wind from which the Khalif suffered. After his death this drum was preserved in the treasury, but was incautiously tapped by a Turkish soldier at the time of Sala d-Din's conquest, and that he, astonished at the surprising result produced, dropped it and it broke to pieces.

The writer Abu Salih describes Hafiz as particularly well disposed towards the Christians, and especially fond of visiting the gardens of some of the monasteries near Cairo, where he showed his goodwill by many gifts and acts of kindness. He even visited the Christian churches, but was careful to enter backwards lest the stooping necessitated by the low door-days might appear to be an act of reverence to the cross which stood within. 


\section{XVI}

\section{THE TWELFTH FATIMID KHALIF, AZ-ZAFIR (A.H. $543-549=$ A.D. I I $49-$ I I 54 )}

At the death of Hafiz in October, II 49 , i.e., A.H. 543, his youngest son Abu Mansur Isma'il az-Zafir li-'Adai dini-llah " "the conqueror of the enemies of God's religion ") was proclaimed Khalif in accordance with the late sovereign's orders. The new Khalif was then only sixteen years of age, frivolous in his tastes, and much given to the society of concubines and to listening to vocal music. One of his first acts was to select Najm ad-Din b. Masal as his chief minister, thus displacing the Emir Sayf ad-Din Abu 1-Hasan 'Ali asSallar, whom he sent to a provincial administration. This new minister Ibn Masal was a native of Lukk, near Barqa, where he and his father had been horse breakers and falconers.

But Ibn Sallar was not disposed to take his deposition from office tamely, and soon assembled a band of armed supporters to help him to recover the wazirate. When the news of this revolt was brought to Cairo the Khalif assembled a council of all the emirs of the state and discussed with them the measures necessary to be taken. All professed unqualified loyalty to the Khalif's nominee Ibn Masal, until a certain aged emir proposed that, if this profession represented their real attitude, they should join in passing a decree of death against the ex-wazir Ibn Sallar. This they unanimously refused to do. "Very well," said the old emir, "then act accordingly." At this the council broke up, all the emirs leaving the city and joining themselves to the party of Ibn as-Sallar. The Khalif gave large sums of money to his nominee Ibn Masal, but it was impossible to raise any supporters in Cairo. Meanwhile Ibn as-Sallar was gathering his forces at Alexandria 
and advanced along the left side of the Nile until he reached Giza on the I $4^{\text {th }}$ of Ramadan, 544, and the following day entered Cairo without meeting with any resistance and established himself in the official residence of the wazir, taking over the control of the affairs of state. At Ibn as-Sallar's advance Ibn Masal fled, having held office only fifty days, and went to the Hawf east of the capital where, with the help of the funds supplied by the Khalif, he raised a force of supporters. As soon as he was firmly established in Cairo Ibn asSallar went out to deal with his rival, but Ibn Masal evaded him and took refuge in Upper Egypt whither Ibn as-Sellar followed him. A pitched battle took place at Dilas, south of IVasta, in which Ibn Masal was killed, his forces scattered, and his head cut off to be carried to Cairo as a trophy. Thus Ibn as-Sellar was left without rival, and the Khalif was compelled most reluctantly to recognise him as wazir. Naturally the young sovereign had no love towards such a minister, and almost immediately began to make plots to rid himself of him.

Although wazir under a Fatimid Khalif, Ibn asSallar was strictly orthodox and gave the whole of his patronage to orthodox teachers of the Shafi'ite school. This position in Alexandria gained him many adherents, and their attachment was still more secured by his foundation of a Shafi'ite college there. He continued the same attitude after his assumption of office at Cairo, so that he was regarded by the people of Egypt as an orthodox champion against the heretical Khalifate. By nature he was cruel and vindictive. An anecdote is related of him that when he was in the army in the days before he held office he had to apply to Ibn Masum, the Secretary of IVar, for help to defray extraordinary expenses incurred by him in the administration of the province of Gharbiya, as the result of which he found himself heavily in debi. The Secretary only replied: "By God, thy discourse entereth not my ear," and Ibn as-Sallar left his presence full of indignation. Long afterwards, when he had risen to a high position, he made search for Ibn Masum, who hid himself fearing retaliation from the one whom he had treated contemptuously as a petitioner. At last the Secretary was found and brought before the wazir 
who had him lain on a board and a nail driven through his ear, Ibn as-Sallar asking him at each cry he uttered, "Doth my discourse yet enter thy ear or not?" (Ibn Khall. ii. 35I).

In the plots against the wazir, az-Zafir's chief confidant was a young man of his own age Nasir ad-Din Nasir, the son of the general 'Abbas who, next to the wazir, was the most powerful man in Egypt. About this time 'Abbas was setting out with an armyl against the Franks taking with him his son Nasir. For a moment we must pause to consider the position of this son, the favourite of the young Khalif. Many years before, in 503 Bullara, the wife of Abu l-Futuh had come to Egypt with a child 'Abbas. Some time afterwards the wazir as-Sallar married her, and in due course his step-son 'Abbas grew up and became a general in the Egyptian army, and had a son, Nasir, who was brought up by his grand-mother in the house of Ibn as-Sallar. Now this youth went with the army which Ibn as-Sallar was sending against the Franks in the company of his father and the Syrian Osama. At Bilbays, on the point of quitting the land of Egypt, 'Abbas can only talk about the delightful climate of Egypt, its many beauties, and regret that he is being exiled to the comparatively unattractive land of Syria. But Osama interrupted his discourse and asked him why, if he liked Egypt so much, did he not get rid of the wazir Ibn as-Sallar and take the wazirship himself, then he would be settled in Egypt permanently. 'Abbas gave serious attention to these proposals and brought in his son Nasir, and the project was discussed by the three, the father 'Abbas presumably being well aware of his son's plotting with the Khalif against the wazir who had sheltered that son in his home and was the husband of his grand-mother. It was finally agreed that Nasir should go back to Cairo and murder the wazir. He, as an inmate of the house, would be the best able to get into his presence and do the deed without premature discovery. So the army remained at Bilbays and Nasir returned. The wazir's house was guarded, but Nasir was well aware of the minister's habits and went direct to the harim which was in a detached building. He had brought a small body of men with him, and together they went through the 
grounds to the harim, where Nasir found the wazir asleep and murdered him. As soon as the guards learned what had happened they broke out in disorder and began to search for the assassins, but Nasir and his men had made good their escape, and the household guards seem to have lacked any one to direct their plans, now the master was dead. This murder took place on the 6th of Muharram, 548 .

As soon as the news was brought to 'Abbas he returned with his forces to Cairo where he soon restored order, and was without delay invested with the office of wazir. The change does not seem to have aroused any other feelings than relief amonst the people at large, for Ibn as-Sallar had been a harsh and cruel ruler, and many had suffered for suspected partisanship with the defeated Ibn Masal. Early in his period of office he had suppressed the Khalif's bodyguard of young men, and put most of them to death, and this had been the inauguration of an almost constant series of executions.

Thus 'Abbas was made wazir, but this appointment resulted in the Khalif's own assassination within the next few months. In the circumstances which led to this it is clear that the chief factor was a close friendship between the Khalif and the wazir's son Nasir, and with this was the evil influence of Osama. It is said that the Khalif made overtures to Nasir to slay his father 'Abbas, presumably intending to make the son wazir in his place; but the details of this are obscure and seem to be very much open to question. It is, however, clear that Osama took a leading part in stirring up the feelings of 'Abbas and his son and inducing them to proceed to this murder, and it is he who definitely states that the Khalif had made overtures to Nasir to assassinate his father, and it seems likely that he says this to excuse his own bad advice.

Both the Khalif and Nasir were of exceptional beauty, of about the same age, and living in close intimacy, - so close as to provoke the scandalous comments of censorious tongues. It seems that Osama was the first to draw attention to these evil rumours. The Khalif had presented Nasir with the fief of Qaliub immediately north of Cairo, and in the presence of his father and Osama Nasir announced this in the 
words, "Our master has given me the province of Qaliub" : at which Osama remarked, "That is not splendid as a wedding gift." This remark sounded offensive to 'Abbas and his son, and in consequence they decided to slay the Khalif. Osama gives the further account that Ibn Munqidh said to 'Abbas : "How can you endure the evil reports I hear about your son?" “"What are they ?" asked 'Abbas. Osama then interposed: "People say that az-Zafir has commerce with thy son and suspect the Khalif of doing with him what one does with women." 'Abbas was aroused and asked indignantly, " But what can I do?" Ibn Munqidh replied, " Assassinate the Khalif, then the dishonour will be purged from thee." Ibn Khallikan (i. 222), in his life of az-Zafir, states that 'Abbas said to his son, "You are ruining your reputation by keeping company with az-Zafir; your familiarity with him is the subject of public talk; kill him then, for it is thus that thou wilt vindicate thy honour from these foul suspicions."

When Nasir had made up his mind to the murder he invited the Khalif to visit him in his house in the Armourers' Market, and there he concealed a band of confederates. On Thursday, the last day of Muharram, 549 (I5th April, I I54), the Khalif went privately with a single black slave to Nasir's house and there the conspirators fell upon him, slew him, and buried his body beneath the floor of the room; according to Osama they slew the black slave at the same time, but this does not seem to have been the case as we find the slave afterwards showing the place where the body was buried. The same night Nasir went to his father and informed him of what he had done.

Next morning 'Abbas went to the palace and asked for the Khalif with whom, he said, he had important business. The household slaves went in search of him but could not find him either in his own rooms or in the harim, and brought the wazir word that they were unable to find where he was. At this 'Abbas, who had remained at the palace gate, dismounted and went into the palace with a band of trusty followers and asked for the Khalif's two brothers, Jibrila and Yusuf, who were soon brought. According to one account he bade one or the other then assume the Khalifate as the 
state could not go on without a head, but they declined. "For," they said, "we have no share in the government, az-Zafir's father disinherited us when he passed it to az-Zafir : after him it is to his son that the authority belongs" (Osama, op. cit.). According to the much more likely account given by Ibn Khallikan 'Abbas asked the two brothers where az-Zafir was, and they replied that he ought rather to ask his son, thus making it clear that they knew whither he had gone the night before. At once he declared, "These two are his murderers," and at his command they were beheaded. 'Abbas then sent for the late Khalif's son al-Fa'iz, then aged five (or two) years, set him on his shoulder and sent for the emirs. Is soon as they had assembled he said, "Here is the son of your master : his uncles have murdered his father, and I put them to death as you may perceive. What is essential now is, that the authority of this infant should be fully recognised." The emirs reply, "We hear and obey." They then gave a great shout which so troubled the infant on the wazir's shoulder that he was ever afterwards subject to fits of trembling (Ibn Khall. ii. 425-6). 'Abbas then took charge of the government, but subsequent events rather belong to the reign of al-Fa'iz.

Az-Zafir was only twenty-two years of age at his death. His tastes had been frivolous, and it would not seem that there was much reason to regret him, but the circumstances of his murder and the general detestation of 'Abbas threw round his memory a halo of lovalty. He was the founder of a mosque known as the az-Zafiri mosque, near the Bab Zawila. 


\section{XVII}

\section{THE THIRTEENTH FATIMID KHALIF, AL-FA'IZ.$$
\text { (A.H. } 549-555=\text { A.D. II } 54-\text { II6o.) }
$$

IN spite of 'Abbas' attempt to throw the guilt of the Khalif's murder upon his two brothers, it was well known both in the palace and in the city that the wazir was the culprit, and both were aroused to the deepest indignation. The emirs in the palace almost at once began to conspire against the wazir, and decided to appeal to as-Salih b. Ruzzik the Armenian, who was then governor of Munya Bani Kharib in Upper Egypt. The letter they sent was coloured black as a sign of their deep mourning, and with it they sent their hair cut off, the ancient Arab symbol of dire distress. As soon as as-Salih received this message he assembled the soldiers who were with him, and read the letter to them asking whether they were ready to support him. They all declared their readiness to follow his lead in avenging the Khalif's murder and in liberating the young successor from the baleful influence which at present overshadowed the throne. With his men asSalih then marched to Cairo. As he approached the city all the emirs and their henchmen came out to join him as well as many of the citizens, so that 'Abbas found himself deserted. At this 'Abbas took to flight, accompanied by his son Nasir and the evil counsellor Osama, and betook himself to Syria.

As-Salih was thus able to enter Cairo without opposition, which he did on the I th of Rabi' I. 549 (May, II 54), and took charge of the government. Guided by the young eunuch who had been present at the murder of az-Zafir he went to Nasir's house and lifted up the stone under which lay the body of the late Khalif. This he removed and buried in the midst of a whole city in mourning. Az-Zafir's sister wrote a 
letter to the Franks at Ascalon, a town which they had captured in 548 when the army setting out from Egypt under 'Abbas failed to appear, and offered them a reward of 60,000 dinars for 'Abbas and his son. This reward induced the knights Templars to go out and stop 'Abbas on his way to take refuge with the Turks in the north: an engagement ensued in which 'Abbas was killed and Nasir taken prisoner. The prisoner was put into an iron cage and sent with an escort and an accredited envoy to Cairo, and the promised reward was at once paid. Nasir's ears and nose were cut off and he was paraded through the city and then crucified at the Bab Zawila, after which his body was burned (on the Ioth Muharram 55I=March, I156 A.D.). Osama who really was the prime instigator of the mischief escaped any punishment.

In the year of Fa'iz's accession (549) the Turks under Nur ad-Din took Damascus and thus began pressing on the Franks from the north. The Egyptian wazir was very anxious to enter into alliance with Nur ad-Din and employed Osama as an intermediary, sending to the Turkish Sultan flattering messages, volumes of his own poetry, and the promise of substantial assistance. But in spite of all these efforts Nur ad-Din, who was extremely cautious and deeply suspicious of the Egyptians, as well, no doubt, as unsympathetic towards the Shi'ite sect. The Egyptian advances received their best endorsement from a victory gained by the Fatimid general Dirgham over the Franks in 553, but even then Nur ad-Din hesitated and would not enter into any definite engagement. This was undoubtedly a mistake, for united action between the Turks and Egyptians would probably have definitely cleared out the Frank settlers, and any further effectual Frankish invasion was impossible in the face of the Turkish power now firmly established in the north.

In 555 the Khalif al-Fa'iz died (on Friday, i $7^{\text {th }}$ Rajab=July, I I6o) whilst in an epileptic fit. 


\section{XVIII}

THE FOURTEENTH FATIMID KHALIF, AL-'ADID

(A.H. $556-567=$ A.D. II60-II I I)

AT the death of al-Fa'iz at the age of eleven years his cousin Abu Muhammad 'Abdullah al-'Adid, son of Jibril, one of the murdered brothers of az-Zafir, and then a child of nine, was proclaimed Khalif. He was treated simply as a prisoner of state, as indeed had been the case with his predecessor, and the government was entirely in the hands of the wazir as-Salih. But as-Salih was not a good ruler; he forestalled provisions and artificially raised prices, levied frequent fines, and managed to contrive the execution of various of the great officers of state whose property was forthwith confiscated. Indeed his besetting sin was avarice, and the resources of the country were greatly exhausted by his constant speculations. At length, in 559, " seduced by long prosperity, he neglected the precautions of prudence" (Ibn Khall. 336), and plots were formed against him. These plots received the support of the Khalif, which means in plain words that they were the result of harim intrigue as is the case with the majority of plots in oriental courts, and the Khalif's guard was told off to act as executioners. One day an attempt was made, but one of the guard accidentally locked a door he was trying to open, and so the attempt failed. A few days later another attempt was made, this time with more success, and the wazir was severely wounded. His attendants managed to kill the attackers and carried the wounded wazir to his palace, where he died on Monday, the igth Ramadan, 559 (Sept., I161). The Khalif visited him on his death-bed, and he gave the sovereign the final messages of his office: he regretted most that he had not succeeded in taking Jerusalem 
and expelling the Franks, as they formed the most serious problem before the country: and he warned his son to beware of Shawar, the governor of Upper Egypt, for he was the most dangerous and unscrupulous rival to the wazir.

As-Sailh was succeeded in office by his son Abu Shuja al-'Adil Ruzzik, but within a year he was deposed and executed by Shawar, whose ambition had been rightly gauged by as-Salih. But Shawar, who was an Arab by birth, was distinctly unpopular, and within a few months he was driven out by Dirgham, who was the favourite of the soldiery and commanded the Barqiya brigade. Expelled from Egypt Shawar went to Damascus and opens negotiations with Nur ad-Din: he represented to him that Egypt was inadequately defended, that it would be an easy conquest, and that the union of the Muslim world would be the best means of effectually getting rid of the Franks, all the arguments already urged by as-Salih with the added attractive detail of conquest instead of alliance. But Nur ad-Din was ever extremely cautious, and moreover he distrusted what he saw of Shawar, who was very evidently a wily and treacherous man, but the ideas suggested seem to have sunk into his mind. Meanwhile circumstances began to force the Egyptian question on Nur ad-Din's attention by making it more or less inevitable that Egypt must fall into the hands either of the Nur ad-Din, or else into those of the Frankish king of Jerusalem. It seems that a subsidy had been paid by the Fatimids to the Franks, though when this began is not recorded. Lane-Poole says that it " must have been recently instituted, for IbnRuzzik, who died in I 6 I, assuredly would have paid no such subsidy to the 'infidels.' Probably Shawar began the payment in $\mathbf{1} 162$, but the fact cannot be proved " (Egypt in the Mid. Ages, p. 177, note). At any rate Dirgham, seeking for increased popularity and confident in the military resources of his country and in the decadence of the Franks, stopped this payment to Amalric, who was at this time king of Jerusalem. As a result Amalric invaded Egypt in the following year $(560)$. Dirgham went out to meet the invaders and was severely defeated at Bilbays. But it was then the time of the Nile inundation, and Dirgham had the 
dykes cut so that the whole country was very soon under water. This made the Franks ready to listen to some sort of compromise, and they accepted such payment as Dirgham offered and withdrew to Palestine. Shortly after their retirement Dirgham was informed of Shawar's intrigues at Damascus, and he at once perceived that his wisest plan was to conclude an alliance with Amalric so that he could count on Frankish help against a Turkish invasion. No doubt this project was known to Nur ad-Din, although Amalric's recent attempt was enough to force his hand, and he decided to take Shawar's advice and send an expedition into Egypt. At the head of the army despatched by Nur ad-Din was the Turkish general Shirkuh, with his nephew Salah ad-Din (Saladin), as his lieutenant, and with him was Shawar as guide and adviser.

Dirgham held Bilbays against the Turks, but was defeated, though able to re-assemble his forces for the defence of Cairo. Shirkuh was able to gain possession of Fustat, but the fortified Kahira was held by Dirgham and he was able to resist all the Turkish attacks made upon it. Then Dirgham, who relied most on the popularity he enjoyed amongst the soldiers, sorely pressed for funds, laid hands on the waqf or " pious bequests," a comprehensive term which in a Muslim land includes all property left in trust for religious and allied purposes, the salaries of the mosque officials, the alms bequeathed for distribution amongst the widows and orphans and pilgrims, the lands left for the upkeep of the mosques and schools, even the copies of Qur'ans presented to a mosque for the use of worshippers and teachers contain on the fly-leaf an inscription declaring them waqf for such and such a mosque; indeed the term includes everything held in trust for religious, charitable, or educational purposes, and in a country like Egypt this implies a very vast total, to-day administered under the supervision of a important department of the state. The actual seizure of this property by Dirgham, an act almost without precedent in Islam, caused a general revulsion of feeling amongst soldiers and people and practically ruined Dirgham's cause at once. The army deserted him and the Khalif followed their lead; only a body- 
guard of 500 men was left to the wazir. Conscious of his mistake Dirgham sought too late to try to repair it. For hours he stood in the great square before the Khalif's palace with his faithful bodyguard and called out like a petitioner for the Khalif's pardon and help, but without any reply being sent out to him. Then he noticed that even as he stood there his men were gradually stealing away from him, until at last only thirty were left. Suddenly a cry was raised that the besiegers had broken through the fortifications and had entered the royal city, which indeed was the case, the Turkish host riding in by the Bab al-Qantara leading from Jawhar's bridge over the canal into Kafur's garden, and at this news Dirgham turned away and rode out through the Bab az-Zuwila on the south. But this road took him through part of the old city and he was recognised by the citizens, pulled from his horse, and beheaded. His head was paraded through the streets and reviled by all, for the mediaeval Muslim had no sympathy with ecclesiastical disendowment, whilst the body was left lying on the ground until it was eaten by the city dogs.

The expedition, though led by Shirkuh, had professedly been to restore Shawar to the wazirate, and now established in office Shawar only desired to get rid of the Turks. He kept Shirkuh out of the royal city, entirely refused to allow him any share in the results of the conquest, and declined to pay the expected indemnity. He felt, no doubt, that the decisive factor had been the revolt against Dirgham rather than the help of the Turks. But Shirkuh was not a likely person to suffer this conduct with impunity, and sent his nephew Saladin to occupy Bilbays and thus hold the Sharqiya or eastern province, one of the four great divisions of Egypt, the other three being Gharbiya or the western province, Qus or Upper Egypt, and Alexandria or Lower Egypt. This move on the part of Shirkuh moved Shawar to appeal to Amalric, and an army of Franks marched down to besiege Bilbays. The siege lasted three months and then Amalric was obliged to retire and call an armistice as the Turkish hosts of Nur ad-Din were proceeding south to the relief of Saladin. It was agreed that the body of Syrians occupying Bilbays should be allowed to evacuate 
without interference, and they marched out between the armies of the Egyptians and the Franks. For the moment matters had produced a stale-mate, but Shirkuh was fully convinced that Egypt could be conquered without much difficulty, and that this would be the right way to check the Franks effectually. Nur ad-Din, with characteristic caution, hesitated over so great an undertaking which would necessitate the employment of his forces in the far south and leave the Frankish kingdom of Jerusalem between his capital and the bulk of his army, but the project was warmly espoused by the Khalif of Baghdad, and at length Nur ad-Din acquiesced and a new expedition started from Damascus in the early part of 562 .

This new force was under the command of Shirkuh who had his nephew Saladin with him as before, but this time he was free from the presence of the treacherous Shawar. They took the desert route so as to avoid the Franks by a long detour and thus reached the Nile at Atfih some forty miles south of Cairo, the ancient Aphroditopolis just north of Wasta, and there crossed the river and commenced the journey down along the west side. Hardly had Shirkuh crossed than the Franks who had heard of the expedition and followed close after appeared on the other side of the Nile and, not venturing to cross in face of the enemy marched along the east side, the two armies keeping pace one with the other, the river between. Both pushed on to Cairo where Amalric encamped near Fustat, Shirkuh at Gizeh. The Frankish king took advantage of these circumstances to insist on a clearer understanding with Shawar, and to see that the terms of the agreement made with him were duly ratified by the Khalif. It was contrary to all precedent for a foreign and nonMuslim prince to pay a personal visit to the Imam, but Amalric insisted, and at length the wazir assented. IVilliam of Tyre has left a graphic description of that visit, and of the astonishing splendours of the palace to which Amalric and his companions were admitted. There he had an interview with the Khalif, a young Egyptian of dark colour, the terms of the treaty were recited, that Egypt was to pay 200,000 pieces of gold at once, and 200,000 pieces later, whilst Amalric on his side was to expel the Syrians. Both parties 
assented and then Amalric held out his right hand to grasp that of the Khalif whilst a shudder passed round the court at this apparent profanity. After a brief hesitation the Khalif also held out his hand covered with a glove. But Amalric exclaimed that as an honest man he preferred to take the prince's bare hand; at this again the court suffered a shock of horror, but the Khalif drew off his glove and grasped the rough hand of the Frankish king.

Amalric desired now to come to grips with the Syrians immediately and began constructing a bridge of boats across the Nile, but this was easily prevented by the Syrians. Amalric then marched his men by night down the river to where it divided at the commencement of the Delta, and there he managed to cross without great difficulty, appearing next morning on the west or left side. $\mathrm{At}_{\mathrm{t}}$ once Shirkuh began retreating southwards towards Upper Egypt closely followed by the Franks. Amalric overtook the enemy at al-Babayn near Oshmunayn about ten miles south of Minia, and there Shirkuh halted and made ready for battle. In the middle he placed his baggage and on the flank he stationed Salah ad-Din with orders to retreat as soon as the Franks commenced the attack, so that they might be drawn off and the Egyptians dealt with alone whilst the Franks were separated from them. These tactics were followed, and whilst Saladin was leading away the Franks and skilfully evading them, the Egyptians were completely routed by the main body of Syrians. As soon as the Franks perceived that their allies were defeated they began to retreat and abandoned their baggage to the Syrians, so this was a definite victory for Shirkuh.

The Syrian leader now began marching back along the left bank of the river but did not continue to follow that route, breaking westwards along the desert route to Alexandria which in due time he reached and took, appointing Saladin governor and leaving an adequate body to support him whilst he retired towards Upper Egypt which he began to lay waste. The Franks had followed as soon as they could, and the allied Franks and Egyptians laid siege to Alexandria. For some time Saladin defended the city with vigour, but the citizens of Alexandria were very soon in revolt against the 
military occupation and the inconveniences inevitable from a state of siege. Alexandria was then, as now, a cosmopolitan town, largely Levantine in population, and essentially a community of merchants, the type least likely to be patient in enduring the restrictions and dangers of a siege. When their discontent broke out in open revolt Salah ad-Din sent to his uncle Shirkuh for relief, and in response he laid siege to Cairo. The news of this counter move induced Amalric to raise the siege of Alexandria and march to the relief of Cairo, first making terms with Salah ad-Din. It is very difficult to discover the real nature of the terms under which Alexandria was abandoned by the Franks as both sides claimed that the operations ended in a victory for themselves. It seems clear that Alexandria was handed over to Shawar which was a score for the Franks: at the same time Amalric paid 50,000 pieces of gold. So far it probably was a bargain struck between the two forces in which we may regard the city as ransomed for 50,00o pieces of gold. But it seems that the Franks left a garrison there and increased the subsidy paid by the Egyptians to roo,ooo pieces of gold: No doubt the right interpretation is that, after the bargain had been made between Amalric and Saladin, the Syrians made these new terms with Shawar to his disadvantage.

After this, in the latter part of the year, Shirkuh retired to Damascus. This seems to suggest that the Turks and Syrians had abandoned the projected conquest of Egypt. But Amalric saw quite clearly that the possession of Egypt was the crucial point in the struggle between the Franks and the Muslims, and himself planned to steal a march on Nur ad-Din and conquer Egypt for himself. With this end in view the raised new forces and again entered Egypt in 564, taking Bilbays and slaughtering the inhabitants. This was a more serious danger to the Egyptians than anything which had happened before, and at once the grouping of parties was changed by new alliances. Now Shawar made alliance with Nur ad-Din and invited the Turkish-Syrian army to come to the rescue. Before any result could be arranged the Franks had pressed on and were threatening Cairo. To save the city from falling into the hands of the enemy the 
Egyptians determined to set fire to the ancient Fustat and abandon it, the newer Kahira was strongly fortified and could hold out on its own account. This plan was carried ont. For fifty-four days the fire raged in Fustat abandoned by all its population, and nothing lay before the invaders but charred ruins and the Old Mosque, and a few other buildings which more or less resisted the conflagration.

Meanwhile Amalric obtained possession of the country and encamped before Cairo. The crafty Shawar managed to deceive him and induced him to consider suggested terms which served to delay operations whilst Shirkuh was collecting a new force and preparing to come to the relief of the Egyptians, nor was Amalric undeceived until Shirkuh arrived and joined the Egyptians. At this the Franks retired and Shirkuh entered Cairo and then made camp outside. Day by day visits of compliment were exchanged between Shawar and the Turkish leader, but Shawar constantly postponed the payment of the money expected and promised for Shirkuh's help and, judging from his knowledge of the man Shirkuh was convinced that he was trying to play off the Frank and the Syrian against one another. At a conference of his generals Shirkuh announced that it was of primary importance to put an end to this state of affairs and recommended that Shawar should be seized and held prisoner. No one was ready to take the first step in the execution of this proposal until Saladin volunteered to do it with his own hands. Soon afterwards Shawar was seen coming with a train of attendants to pay one of his customary visits. Salah ad-Din with his guard rode out to meet him, and as they rode side by side he suddenly grasped Shawar's collar and pulled him off his horse, at the same time ordering his men to fall on the attendants of the wazir. Shawar was then taken to a tent and held prisoner. For some time Shirkuh was doubtful what the result of this measure would be, then an embassy came from the Khalif bringing the official pelisse, the outward badge of the wazirate, to Shirkuh and asking for the head of Shawar. This was equivalent to appointing Shirkuh as ruler of Egypt, and was a final and definite step in ending the independent existence of the Fatimid Khalifate and estab- 
lishing the suzerainty of Nur ad-Din, whose servant Shirkuh was. On WVednesday, the I 7 th of Rabi' II. 565, Shirkuh was formally invested as wazir, and aroused popular enthusiasm by permitting a general looting of Shawar's palace. Shirkuh, however, held office only two months and died on Saturday, 28th of Jumada II., being succeeded in his office by his nephew Saladin. Soon afterwards Aiyub, Saladin's father arrived in Egypt, and his son offered to resign his appointment to his father, but Aiyub refused to accept this sacrifice and urged his son to continue in the exercise of the functions which he had receivedi as the most trusty and efficient lieutenant of his uncle Shirkuh.

Two years later $(567)$ a message was received from Nur ad-Din ordering the khutba in Egypt to be changed and the name of the 'Abbasid Khalif to be used in place of the Fatimid. Saladin hesitated fearing a revolt of the people at this termination of the Egyptian Khalifate and proclamation of their being incorporated in the Khalifate of Baghdad. But fresh orders from Damascus insisted. In Cairo there was much reluctance amongst Saladin's officers to venture on this change, but at length a Persian visitor named al-Amir al-Aahin offered to ascend the pulpit next Friday and pronounce the new khutba, and this was accepted. On the following Friday the Persian did so, and no single word of protest was uttered: the Fatimid dynasty fell without being the object of more than private comment, and Egypt acquiesced in the change without discussion or even taking any particular notice. At the moment the Khalif al-'Adid was ill and confined to his rooms. The members of Saladin's suite debated whether he ought to be informed of the change, but it was agreed that if he recovered it would then be time enough to tell him, and if he did not recover he might as well die in peace without knowing that his dynasty had fallen. Shortly afterwards he died in this peaceful ignorance.

This surprisingly commonplace end of the Fatimids is a striking comment on their history. As organised by 'Abdullah b. Maymun the Isma'ilian sect was a secret society, and this society had established an empire in which it ruled over subjects who, though loyal to their rulers as political sovereigns, were totally 
out of sympathy with the society's known or supposed aims. So far as these had become prominent from time to time they had only produced difficulties and friction, most pronounced in the incidents connected with alHakim; the wiser and saner advisers of the throne undoubtedly made it their aim to push the sectarian element into the background, or get rid of it altogether. Yet all through the history of Egypt, at least up to the time of al-Mustansir, that sectarian element was very distinctly present and the Fatimid Khalif as the pontiff of the Isma'ilians was visited by pilgrims from Persia, Arabia, and other parts. As a sectarian movement the Fatimid adventure had two off-shoots which are still to some extent living forces. The Druses of the Lebanon still form a vigorous and flourishing community of no small political importance. Their religious tenets have been long a secret, though many details have leaked forth; but now there is a " modernist" party, chiefly of the younger men, amongst the Druses, and these desire to reveal their religious beliefs more fully feeling that secrecy has only tended to misrepresentation of their community, and believing that the moral ideals which they hold together with their combination of agnostic and pantheistic doctrine furnishes a religious system likely to gain many converts at the present time. How far these modernists will succeed in divulging their beliefs, and how far their movement will receive the sympathy of the heads of the sect remains to be seen. It is understood that Dr. Bliss of Beirut will be the probable intermediary of communication with the western world if this disclosure takes place.

The second important off-shoot is that of the Assassins. The Syrian branch of the Assassins was completely exterminated, and the great headquarters at Alamut was destroyed by the Turks, but besides these two greater branches there were many minor groups of the sect which have lived out a secluded existence scattered in various parts of central Asia and India, and undoubtedly exist at the present day. As late as 1866 an English judge in Bombay was calied upon to decide a succession case according to the jurisprudence of the Assassins. Prof. Browne states, "remnants of the sect, as I was informed by a very intelligent and 
observant Babi dervish of Kirman, of whom I saw a great deal when I was in Cairo in the early part of the year 1903, still exist in Persia, while in India (under the name of 'Khojas' or 'Khwajas') and Chitral (under the name of 'Mullas '), as well as in Zanzibar, Syria, and elsewhere, they still enjoy a certain influence and importance, though it requires a great effort of imagination to associate their present pontiff, the genial and polished Agha Khan, with the once redoubtable Grand Masters of Alamut and the "Old Man of the Mountain '- 'Le Vieux' of Marco Polo's quaint narrative", (Browne : Literary Hist. of Persia, p. 460).

As a political force the Fatimids rapidly vanished. In the great struggle between Franks and Turks they had for a while hindered the co-operation of the Muslims under Turkish leadership, and perhaps had contributed to the weakness which had allowed the establishment of a Frankish kingdom in Jerusalem, though this weakness would be sufficiently explained by the fact that the earlier Turkish migration westwards had just ceased, and the greater movement which followed had not yet begun. When Saladin swept aside the remnants of the Fatimid Khalifate it disappeared without leaving any appreciable mark on contemporary history.

On the religious history of Islam the Fatimids left even less impression. They were entirely excluded from the theological life of the Muslim community, save that they probably contributed to the strong disfavour with which the orthodox regarded philosophical and scientific studies as these took a suspected colour by reason of the sympathy with which the Shi'ites generally, and the Isma'ilians in particular had regarded them. 


\section{XIX}

\section{THE FATIMID KHALIFATE IN ITS RELATION TO GENERAL HISTORY}

A FEW words may be added to define more plainly the part taken by the Fatimid Khalifate in the general course of history. So long as the Fatimite movement merely took the form of a sectarian body in Asia it had hardly more than a local interest, and even the formation of a Fatimid Khalifateat Kairawan does no more than illustrate the disintegration of the empire of the Khalifs of Baghdad. But the conquest of Egypt brought the Fatimids into relation with a wider world and induced them, unwisely no doubt, to venture on the conquest of Syria. It is a question how far the power ruling in Egypt ever can be free from Syria: the ancient Pharaohs were drawn into Egyptian expeditions, and the two lands have been closely involved one with the other ever since: nearly always Syria has proved the grave in which the prospects and hopes of Egypt have been buried. In the days of the Fatimids Syria was the battle ground of the Near East, and every country from Byzantium to the Oxus was more or less drawn into the conflicts there, whilst in the later part of the period the whole of Christendom, except Spain, was involved: and every power of East or West found there either severe loss or total ruin. The whole course of the history of the 9-12th centuries of the Christian era shows the gradual sucking in of Muslim and Christian powers to this maelstrom, and in every case with disastrous results.

The whole period of the Fatimid Khalifate, from the first formation of the parent sect or conspiracy to the final downfall before Salah ad-Din, may be divided conveniently into three periods; (i) the rise of the Isma'ilian sect and the establishment of a Khalifate 
claiming Fatimid descent at Kairawan, (ii) the conquest of Egypt and the period of more or less prosperous rule over Egypt and Syria, and (iii) the period of decay under the attacks of the Saljuq Turks and the Crusaders to its final downfall.

(i) The Formation of the Fatimid Khalifate. (A.H. $260-356=$ A.D. $873-966$.)

This was the period during which the Isma'ilian sect was founded, spread to North Africa, and a Khalifate was established at Kairawan. It was a time during which the Khalifate of Baghdad was passing through a course of rapid decay : under no other circumstances would such progress on the part of the Isma'ilis have been possible. The Khalif Harunu r-Rashid died in I93 $(=808)$ whilst actually proceeding against a rebellious son in Khurasan. His death was followed by a civil war at the end of which his rebellious son was established as Khalif, but soon afterwards in $205(=820)$ Khurasan was practically lost to the Khalifate and passed into the hands of the independent dynasty of the Tahirites, who ruled nominally in the Khalif's name but paid him no obedience. Tahir himself was an Arab, but his supporters were mainly Persians, and this begins the period of Persian political supremacy which lasted until the rise of the Turks in the middle of the 4 th cent. The Saffarids who ruled in Khurasan from 260 to 290 A.H. were purely Persian, and the Samanids who arose in 288 and ruled until 400 . All these maintained themselves in the east, but in 320 (=932) the Buwayhids, a Daylamite tribe from the shores of the Caspian Sea came down into the very heart of the Khalifate, and from 344 until 447 controlled Baghdad, holding the Khalif as an ornamental figure to adorn the pageant of state. Not only were these Buwayhids Persians but, like the Saffarids and Samanids, they were Shi'ites, not themselves recognising the Khalif as the true ruler of Islam, but using him simply as a tool to give effect to their rule over those who did. This was the golden period of Arabic philosophy and literature.

In North Africa the Aghlabid dynasty of Zairawan went down before the followers of the Fatimid Mahdi, who increased in power and prosperity until they conquered Egypt in 356. Only in the far West the rival 
Khalifate of Cordova held its own, minor independent states were formed in the further parts of North Africa, and in Sicily a popular movement declared for the orthodox Khalif of Baghdad.

During all this time Islam hardly enters into the political history of Europe, save in Spain. The Byzantine Empire held its own owing to the weakness of Islam: the Latin Empire was in process of disintregation and new states were being formed in the west. Almost contemporaneously two sturdy races begin to appear at points far removed, the Turks who are gradually filtering across the Oxus into Persia and becoming Muslims, and the Northmen who are settling on the sea-board of the North- II est of Europe and becoming Christians.

(ii) The Golden Age of the Fatimids. (A.H. 356-469 =A.D. $966-$ I076.)

During the period of the decay of the Abbasid Khalifate the Fatimids were able to seize an important part of the Abbasid dominions and make themselves rulers of Palestine and Syria, with more or less intermittent control over Arabia. At this time the three leading powers in the Near East were the Khalifate of Baghdad, the Fatimid Khalifate of Egypt, and the Byzantine Empire, but of these-three the Fatimid Khalifate of Egypt, and the Byzantine Empire, but of these three the Fatimid Khalifate was the most vigorous and aggressive. Under Karl the Great the II estern Empire had assumed a kind of protectorate over the Christians in Palestine, but in Fatimid times this had become obsolete. The two rival Khalifates were separated by a wide gulf of religious difference, how wide cannot be appreciated without following the history of the formation and development of the Fatimid Khalifate. Both made overtures to the Greeks, but the relations of Byzantium with the Muslim world generally turned on questions connected with Fatimid rule: Fatimids and Greeks faced one another in North West Syria, and it was only in Sicily that the Greeks had to deal with the Baghdad Khalifate. Before the beginning of this period Crete which had fallen into the hands of the Muslims in A.D. 825, was recovered (in A.D. 96I): Sicily, conquered by the Muslims between A.D. 827 and 878 , remained in their hands but, 
after the Fatimid conquest of North Africa it revolted and gave in its allegiance to the Khalifate of Baghdad. North Africa was divided amongst various Muslim groups, and Spain was fully occupied with its own problems. In A.D. I038 Byzantium lost control over North Syria, so that on the whole the Greeks were receding before the Muslirns. In A.D. IO29 (=A.H. 419) there was, however, a modus vi vendi reached between the Fatimids and the Greeks by which, in return for help during famine, the Muslims were allowed to have a mosque in Constantinople provided prayer was offered there for the Fatimid Khalif, and, apparently, the Christians were allowed freedom to visit Jerusalem. The persecution of Christians under Hakim had culminated in the destruction of the church of the Holy Sepulchre in A.D. I O09, but this was re-built soon afterwards : the persecution was an isolated incident : in Muslim lands generally neither Christians nor Jews suffered any serious disabilities, the penal laws were long obsolete, and the only penalty enforced was against a Muslim who became a convert to another religion. An additional tax had to be paid by non-Muslims, but this was in lieu of military service from which they were exempt.

The real stirring of history lay in the extreme east and west, in the rise of the Turks and of the Normans, both gradually converging upon western Asia and at the close of this period are both approaching Syria, bringing even greater disasters to their co-religionists than to those whom they regarded as their foes. During the period under present consideration both were already in this arena in small numbers, employed as mercenaries by all the three Near Eastern powers, Turkish soldiers of fortune serving under the Khalifs of Baghdad and under the Fatimids of Egypt, Northmen serving in the employ of the Emperors of Byzantium, but neither Turks nor Northmen had as yet moved in in sufficiently large numbers to become independent factors in politics.

The first assertion of the Turks appears in the career of Mahmud of Ghazna. Turkish soldiers had been employed by the Samanide of Khurasan, and one of these, Alptekin, was made governor of Khurasan, but at a disputed succession in the house of Samani he 
unfortunately took the side of the candidate who proved unsuccessful and so had to flee the country. With a body of followers he established himself in the mountain fortress of Ghazna (in A.H. 350=A.D. 96I), and there he and his son Sebektakin held their own, nominally as vassals of the Samanids, really as an independent brigand state. The third ruler of Ghazna, Mahmud, declared himself independent in $390(=999)$, and received investiture directly from the Khalif of Baghdad, assuming the title of Sultan, a title which he was the first to introduce into the community of Islam. Mahmud of Ghazna is one of the brilliant figures of history, but one whose importance can easily be over-estimated. In a series of twelve expeditions to India he won both fame and booty, but was not in any real sense a conqueror of India. In A.H. 407 (=AD.D I016) he extended his power northwards to the shores of the Caspian Sea, and here before long he was brought into contact with other kinsmen of his own, Turk-sliving across the Oxus, and it was the advance of these Turks led by the Saljuq tribe which, in his son's days, cut off the Sultanate of Ghazna from Persia and the West and compelled the Ghazni dynasty to turn its attention eastwards. This led to the foundation of a Muslim state in India which, under the successive rule of Turks, Afghans, and Mongols, had a continuous existence to the time of the Indian Mutiny in the 19th cent. Although Mahmud and his followers were Turks he gave the civil administration mainly into the hands of Persian officials, and thus Persian became the court language of Muslim India, though Arabic was sometimes employed in important charters, -both foreign languages to rulers and subjects; and thus, when the native Hindi began to be used as a literary medium it appeared as a language which, though thoroughly Hindi in structure and grammar, had a vocabulary full of Persian and Arabic words, and in this form is known as Urdu or Hindustani. Thus Indian history, through the pushing eastwards of the Ghazni Turks by the advance of the Saljuqs, connects with the history of the West.

The Persian dynasties of the Saffarids, Samanids, and Daylamites were Shi'ite in religion, but the Turks were Sunni, that is to say "orthodox" in the sense 
of adhering to the traditional school which was in communion with the official Khalifate of Baghdad, so that when they came westwards they came as its champions, in contrast to the Normans who were unfriendly towards the Greek Church.

The Saljuq Turks migrated from Turkistan to Balkh about 345 (=A.D. 956), and there accepted Islam. They settled on the farther side of the Oxus about 20 parasangs from the town of Balkh, and there they were found by Mahmud of Ghazna. He removed then to the near side of the Oxus and distributed them through the province of Khurasan where, as they were broken up into small groups, they were harshly treated, and plundered until a body of 2,00o fugitives fled to Ispahan for protection. The governor there wished to employ them in the army, but Mahmud sent orders that they were to be imprisoned and their property confiscated, and followed up these orders by sending a force to scatter them. After this they took to brigandage under a leader named Tughril, and finally were pardoned by Mahmud on condition that they reduced the whole province of Khurasan to obedience to him. This work they took in hand but, in the days of Masud, the successor of Mahmud, they were able to establish their own independence and compelled the Sultan of Ghazna to abandon all control over Persia and turn his attention eastwards (Ibn Khall. iii. 224-226x).

The Saljuqs were now so prominent that al-Qa'im the Khalif of Baghdad sent to Tughril as a loyal Sunni to deliver him from the tyranny of the Buwayhids. In response Tughril marched to Baghdad and formalls restored the temporal power of the Khalif in 447 (=A.D. I055), though this soon meant simply that the Khalif was under the guardianship of a Saljaq Turik instead of a Daylamite Buwayhid; though there was this much gain, that the Saljuqs were theoretically orthodox supporters of the Abbasid Khalifate.

The Saljuqs were now established as the champions and defenders of the Baghdad Khalifate. Under Tughril's successor, Alp Arslan, they came into direct conflict with both the Fatimids and the Greeks. By 457 (=A.D. 1068) they were in possession of Georgia and Armenia, and had become a very serious and pressing menace to the Byzantine Empire. A few 
years later the Emperor Romanus IV. was totally defeated by them in 460 (=A.D. IO7I), and all Asia Minor lay open to the Turks, though the Saljuq position there was insecure until they took Antioch from the Greeks. Alp Arslan was succeeded by Malak $k$ Shah who, in the course of $467-477$ (=A.D. 1074-1084) established the Saljuq power in Asia Minor, and in 469 conquered Jerusalem from the Fatimids, so that practically the Saljuq Sultan, theoretically the Commander-in-Chief serving under the Khalif of Baghdad, was the master of all Western Asia. This brings us to the close of the second period and to the end of the golden age of the Fatimids.

Meanwhile in the West the Normans, destined to be the protagonists of the Saljuq Turks, were becoming a leading power in another way. In Io38 we find them serving in Sicily, in 1040 they were conquering Apulis, and soon afterwards they began minor encroachments on the Byzantine Empire. Their chief settlement, Normandy, dates from $9 \mathrm{I} I$, and it is significant that this was one year after the foundation of the Abbey of Cluny, from which proceeded a religious reformation which found its warmest supporters in the Normans. When Pope Leo IX. made an expedition against the Normans in Apulia and was defeated by them, his greatest surprise came in finding his victorious enemies ready to pay him a reverent loyalty far beyond anything he had previously experienced. The recently converted Normans were no less definite in their orthodoxy as Christians than the recently converted Saljuqs in their orthodoxy as Muslims.

It is, no doubt, impossible to regard the Crusades as entirely religious in their spirit and character, but it is equally impossible to ignore the fact that religious motives played a very large part in their history. We may venture to say that they commenced under the influence of the Cluniac reformation, and that most of those who took part in the First Crusade, if they had any regard for religion at all, accepted the Cluniac standards: whilst the Second Crusade was still more definitely associated with the Cistercian order, itself an after-math of the Cluniac reformation. The attitude of the Latin clergy towards the Greek Church was exactly the same as that of the Cistercian missionaries towards 
the native Keltic clergy of Ireland a few years later: wherever religion enters into the programme of the Crusaders it is always treated according to Cluniac standards, and everything is disapproved which does not conform to those standards. The Normans and Burgundians formed the most loyal contingent of those who contended for Cluniac ideals, and they, the Normans especially, formed the real nucieus of the First Crusade. The Crusading movement cannot be separated from the Cluniac reformation.

In referring to the Cluniacs we do not confine the term to those who were actually monks in the Abbey of Cluny, nor even to those in the priories which were in obedience to Cluny, but extend it to all those portions of the Latin Church which followed the leadership of Cluny in the way of church reform and saw the ideal Christianity in the Cluniac programme, an ideal of which we have the fullest expression in the writings of S. Peter Damian. These reformers were loyal to the Papacy, but to an idealised Papacy reconstructed on Cluniac lines; they were outspoken in their criticism of the actual Papacy and its entourage as it existed in the Ioth cent. Incidentally Rome ceased to be the chief place of pilgrimage, not because there was any repugnance felt towards Rome or the Papal court, but because, in conformity with the spirit of Clung, a greater emphasis was laid upon the suffering Christ, and thus greater prominence was given to the sites connected with the Passion: thus Palestine tended to become a "Holy Land," and Jerusalem itself the chief object of the pilgrim's devotion. Thus, early in the IIth century, the thoughts of the leading and most vigorous element in the Latin Church began to turn towards Jerusalem and predisposed men to regard the liberation of the holy sites of Palestine from infidel rule as a work of piety.

In 1074 Pope Gregory VII., himself a product of the Cluniac movement, laid a programme of reform before a council assembled at Rome; the liberation of Jerusalem did not actually figure in this programme, but later in the same year (on Dec. 7) we find it expressed in a letter to Henry IV. (cf. Gregor. Pp. VII. Epist. II. 3 I, in Jaffe: Mon. Greg., pp. I 4415 , but a previous suggestion had been made by Silvester II. as far back 
as 999). No doubt the news of the Saljuq advance into Asia Minor had something to do with his proposal, the report of vast numbers of " Christians living beyond the seas " slain by " the pagans " so that the Christian community was reduced to nothing (id. p. I45), but the chief point was that Gregory and his party looked at the world through a Cluniac medium and so to them Palestine was the " Holy Land," and it was a terrible thought that the sacred sites of Christ's passion were in the hands of unbelievers. The violent storms aroused by the reforming programme of 1074, however, prevented any action being taken in this direction.

(iii) Third Period. Fatimid decline. (A.H. 469-564 =A.D. $1076-1168$.)

When Urban II. became Pope in 1087 events had moved forward with startling rapidity. In 1076 Jerusalem had fallen into the hands of the Saljuqs, and the Byzantine Empire was practically deprived of all its Asiatic possessions, so that both Egypt and Byzantium were at bay. In this desperate crisis the Greeks made an appeal to the West, and this was laid before two councils assembled in the year 1095, the one at Piacenza in March, the other at Clermont-Ferrand in November. and from these councils proceeded the First Crusade.

At the moment the three great powers in the Near East were the Byzantine Empire, the Fatimid Khalifate, and the Saljuq Sultanate, but of these the two former were on the defensive and steadily losing ground; the Fatimids had just suffered the loss of Jerusalem, the Greeks had lost North-IVest Syria and practically all of Asia Minor. The Saljuqs were the leading military power and held the Khalifate of Baghdad absolutely in subjection, but they already showed signs of decline, their empire was beginning to be divided amongst provincial rulers known as atabegs, and these were getting to be more or less independent of the central authority : it was the old story of the Khalifate over again. Both in Cairo and in Baghdad the real power was in the hands of the wazir or prime minister.

In 1097 the First Crusade came east: its advent was hailed by Byzantium and by the Fatimids, both believing that it would prove a check to the Saljuqs. The Greeks were the first to be undeceived, and soon found that the Crusaders were extremely undesirable neigh- 
bours. The Fatimids were anxious to join in alliance with the Crusading forces but wanted to recover Jerusalem. It was a purely religious motive which prevented this, - the Crusaders were unwilling to leave the Holy Sepulchre in Muslim hands.

So far as the history of Western Asia is concerned the Crusaders produced very great results, but these were purely destructive in character. They checked the Saljuqs and effectively broke their power, though that power had already commenced its decline before the Crusaders' arrival: but this only made way for a new Kurdish power. The Crusades as a religious war provoked an anti-Crusading movement, quite distinctlv religious in its character, on the Muslim side,-a Holv War to resist the champions of the Cross. The first mover in this was Zengi atabeg of Mosul, and it was continued by his son Nur ad-Din. In the employ of these atabegs of Mosul was a Kurdish soldier named Ayyub who, at the death of Zengi in 54I (=A.D. I146) moved to Damascus, and eight years later became governor of the city. From him were descended the Ayyubites, Shirkuh and his nephew Salah ad-Din, the instruments by which the Fatimid Khalifate was finally destroyed. It was not the rise of a new power but merely the development of one of the minor local states formed from the disintegrating Saljuq empire.

The immediate result of the Crusades lay in the formation of Latin states in Palestine and Syria, at Jerusalem, Edessa, and Antioch, and in the final exclusion of the Fatimids from Syria, but none of these states had any stable foundation. Only in quite minor issues can we find any permanent traces of the Crusaders' presence in Asia. In the East their memory lives as a legend of tyranny and religious intolerance, whilst a few Arab tribes preserve a tradition of Crusading blood. In the West it may be possible to argue that only the Carmelite Friars show any enduring trace of the Crusades : almost every influence which has been traced to the Crusades seems to have been due to intercourse between Muslim and Christian in Spain, or to Frederick II. in Naples and Sicily,-though, of course, it might be argued that Frederick himself was a product of the Crusading age : yet it must be remembered that Frederick came more under the influence of Jews and 
Muslims expelled from Spain by the intolerance of the Muwahhid rulers.

The work of Salah ad-Din who put an end to the Fatimid Khalifate of Egypt and to the Latin kingdom of Jerusalem, restored the semblance of authority to the 'Abbasid Khalifate of Baghdad, but the following period $567-656$ (=A.D. II 7 I-I 258 ) saw no real reconstruction of the Khalifate : existing conditions were merely bolstered up whilst internal decay proceeded on its course. In $656\left(=\right.$ A.D. $\left.125^{8}\right)$ the Khalif finally went down before the Mongol invasion which was simply destructive in its results. It was not until two centuries later that the Ottoman Turks sweeping westwards evolved a new order from these elements of decay and founded an empire which has lasted some 500 years, receiving from the last exiled representative of the 'Abbasids such title as he could give to the historic Khalifate, and practically re-organising the Sunni Muslim world on strictly orthodox and traditional lines so that, in spite of occasional dissentients, it generally won the esteem and loyalty of the world of Islam. 


\section{$\mathrm{XX}$.}

\section{THE LATER HISTORY OF THE ISMA'ILIAN SECT}

THE Fatimid Khalifate had its origin in a religious sect which professed to represent the true Islam tranmitted through a line of seven Imams who alone understood the real meaning of the religion proclaimed by the Prophet Muhammad: the first of these was the Prophet's son-in-law 'Ali, and the last Isma'il the son of Ja'far as-Sadiq or his son Muhammad, with whom, according to the earlier teaching, the line ended as the Imam passed into concealment, the leaders of the sect keeping the teaching alive and preparing the way for his return to the visible world. At a later date the leaders claimed themselves to be the Imam's descendants, the "concealment" being no more than a hiding from the persecuting Khalifs of Baghdad, and so they were the continuers of the sacred tradition, and on this claim rested the Khalifate of Kairawan and of Egypt. It is, of course, extremely difficult to make anything like a fair estimate of the religious work and influence connected with such a movement, and especially because it professed to cover its religious teaching with a veil of secrecy, and also because, during the duration of the Fatimid Khalifate in Egypt, the historians are almost exclusively occupied with recording the political activities of the rulers and make only occasional and allusive references to the sect as a religious body. It seems possible to distinguish three different elements in the sect, (i) the philosophical element which is one of the results of Greek philosophy and especially of the teaching of Aristotle as interpreted by the neo-Platonists and represented in an oriental dress after passing through a Syrian and Persian medium. Such teaching is traditionally associated with Ja'far as-Sadiq, and 
seems to have been the real doctrine of the sect at its first formation, but that was revealed only to the initiated, and apparently it was never checked or restated in the light of the more accurate study of the text of Aristotle which was the work of the "philosophers " of the fourth century A.H. (ii) The definitely Shi' $i$ doctrine of the incarnation of the divine spirit in the Imam passed on by transmigration from 'Ali to his descendants. And (iii) the purely political element which cared nothing about philosophical speculation or Shi' $i$ doctrine, but saw in the sect promising elements of a conspiracy against the 'Abbasid Khalifate. But it does not seem true to say that the whole movement was wholly political, as though there were no realit; in the attachment to philosophical or Shi'ite ideas.

When the Isma'ilian sect emerged first into the open arena in the Qarmatian rising the doctrinal element, especially (i), had effectively undermined all adherence to orthodox Islam; how long the Qarmatians remained attached to Shi'ite claims we do not know, but they do not seem to have attached much importance to them. In history the Qarmatians appear as simply anti-Muslim and offensively irreligious: they give evidence of no ideals whatever beyond the ordinary aspirations of brigands, though we must bear in mind that only account of them is such as their enemies have given us. In fact they seem to have been simply a robber band released from all pretence of religious beliefs and inspired by a hatred of Islam due, no doubt, to oppression at the hands of Muslim rulers.

The Khalifate at Kairawan and Cairo presents a much better test of the religious tendencies of the Isma'ilian sect. In this case the sectarian leaders established a strong government and, on the whole, ruled well. The government was founded by those who seem to have believed sincerely in the Fatimid claims, but the great majority of the subject population had no sympathies in that direction : they were quite willing to be ruled by Shi'ites, but had no inclination to turn Shi'ite themselves. The extravagant claims of incarnation etc. which made so strong an appeal to the Persians found the Berbers and Egyptians irresponsive. The Isma'ilians made an attempt to press them into their sect when first the Mahdi was established at 
Kairawan, but this policy was soon abandoned and very rarely tried again, though it seems that the regular meetings of the sect and the instructions given by the du'at were continued until some time after the reign of Hakim. For the most part the Fatimids were quite content with political power and did not interfere with the religious convictions of the people. The condition seems to have been that the Isma'ilians formed a kind of free-masonry which was, to some extent, the " power behind the throne," though it was by no means necessary for the officers of state to be members of that brotherhood themselves, and in later times, when the wazirs were practically independent princes, cases occur in which the official government is actually unfriendly towards it. In the later part of the Fatimid period the only mark which distinguished its rule from that of the orthodox Khalif at Baghdad seems to have been that the khutba before the Friday sermon was said in the name of the Fatimid, and that of the 'Abbasid was not mentioned. The whole sectarian teaching seems to have evaporated steadily in an Egyptian atmosphere which was one of steady indifference. The philosophical teaching which had been the first object of the sect, died away in Asia, and was then transmitted to Spain which formed a kind of orbis ulterior of Islam, leaping over Egypt altogether, as though its premature development in the Isma'ilian sect had inoculated the Fatimite community against it. The characteristically Persian doctrines of incarnation and transmigration took no hold in Egypt or Ilfrikiya : when they were vigorously preached by Persians in Hakim's time they only provoked a riot.

We can hardly treat religion as a matter of race, for there seems no good evidence for extending hereditv so as to include matters of cultural development: culture, which includes religion, is transmitted by contact not by descent, it is learned not inherited : and it is very doubtful how far psychological pre-dispositions can be inherited. But culture exists in different areas with distinctive characteristics so that it is not easy for persons of one culture-area to appreciate the outlook of those of another, although there is a constant culture-drift passing between the two. In North Africa there is a tendency to pay exaggerated 
honour, which might be described as actual worship, to the murabits or saints, but it is quite independent of the incarnation theories which prevail in Persia and India, and so we may say that this, the characteristic tenet of the Isma'ilis as Shi'ites, found itself in Egypt and North Africa in an unsympathetic atmosphere, and was gradually starved out. Perhaps we may take the accession of al-Hafiz in A.H 524=A.D. I I 3 I, when the wazir in office was antagonistic to the Isma'ili doctrines, as the probable date by which the doctrines of the Isma'ili sect had ceased to have any meaning in Egypt, and consequently that in which the parent Isma'ili sect was practically obsolete. Whatever may have been the sincerity of its first founders, of those whom we credit with a desire to spread the philosophical theories learned from Greek philosophers and formed into a body of doctrine subversive of the traditional teaching of Islam, or of those who were attached to the incarnation theories of the Persians, it is clear that the purely political element finally gained the upper hand, and in due time discarded all the religious and philosophical thought which, from their point of view, had outlived its utility. In Fatimid Egypt the sect was rather like a free-masonry under royal patronage, and when this patronage came to an end the sect died a natural death. That the teaching of Duruzi and Hamza in the reign of Hakim met with such violent opposition is convincing that Shi'i teachings were uncongenial to the Egyptians, though it does seem that under Fatimid rule Cairo was much frequented by Persian visitors and pilgrims.

The subsequent influence of the Isma'ili sect shows itself in off-shoots which do not connect with Egypt or North Africa. So far as we know the first Isma ili propaganda in India took place about A.H. 460=A.D. 1067, about the time when the Fatimid Khalifate in Egypt was just coming to the end of its flourishing period. At that time a missionary named 'Abdullah came from Yemen and preached in North-West India, and is claimed as the founder of a sect known as the Bohras which is found scattered through many of the trading centres of the Bombay presidency, though some attribute its foundation to a later teacher, the Mullah 'Ali. Many of the Bohras, however, have become Sunni (cf. 
Nur Allah ash-Shushtari, quoted in Arnold: Preaching of Islam, pp. 275-7).

The Khojah sect proper was founded by a da'i named Nur ad-Din who was sent from Alamut about A.H. 495 (=A.D. IIOI), or perhaps later, and so is an off-shoot of the Assassins (cf. p. 214 supra), Nur ad-Din changed his name to the Hindu Nur Satagar and made many converts from the lower castes of Gujerat. About A.D. I 430 the head of this Khojah sect was Pir Sadr ad-Din who adapted its teachings to suit Hindu ideas; according to him Muhammad was Brahma, Ali was Krisna in his tenth incarnation (avater), thus accepting the previous nine incarnations of Hindu mythology and adding this extra one as an adaptation to Shi'ite ideas, and Adam was Siva. This Hindu rendering of Isma'ilian ideas was detailed in a book which he produced and called the Dasavatar, which serves as the sacred book of the modern Khojahs and is read beside any member of the sect on his death-bed. In this semiHindu teaching it is difficult to trace any real continuity with historic Islam, and it is rather grotesque to find that the members of the sect, numerous in the chief trading towns of western India, have in recent years taken a leading part in Islamic agitations against British rule.

These Indian Khojahs represent the Assassin branch of the Fatimite wing, but there are other representatives of the same branch scattered all over the Muslim world, though nowhere forming an established community quite in the same way as in West India. The Bohras, or such of them as have not turned Sunni, represent the older parent stock of the Isma'ilians. The Druzes of Mount Lebanon maintain the off-shoot formed during the later years of al-Hakim, and these show a clear continuity than any other relic of the sect which set the Fatimid Khalifate upon the throne of Egypt. 


\section{BIBLIOGRAPHY}

(A). Original authorities accessible in translations or extracts.

Abraham the Syrian.

Leroy: Histoire d'Abraham le Syrien patriarche copte d'Alexandrie. (In "Revue de l'Orient Chrétien" : igog, pp. 380 sqq.)

Ibn Adhari (d. 662).

Histoire del'Afrique et del'Espagne. Dozy. Leide. 1848 .

Ahmad b. Yahya al-Baladuri.

Liber expugnationis regionum. Lugd. Batav. $1863^{-6}$ (in 3 parts).

Arib b. Sa'd of Cordoba (circ. 366).

Nicholson : Account of the establishment of the Fatemite dynasty (translation), Tubingen and Bristol, 1840. (The history goes down to the end of al-Muqtadir's reign, A.H. 320.)

Edition in Arabic, by de Goeje. (Supplement to Tabari's history.)

Ibn al-Athir ("Ali b. Muhammad).

Dozy : Hist. Abbadidarum, vol. ii.

Jornberg: Ibn-el-Athir's Chronika. Lund. $185 \mathrm{I}$.

Baha ad-Din (Muhammad b. Husayn).

Vita Saladini. Ed. Schultens. Lugd. Batav. I732. Eutychius.

In Migne, Patrologia Graeca, vol. ci. pp. 889, etc.

Edit. in Corpus Script. Christ. Orientalium, vol. i. 1906 -vol. ii. Igog. Ed. Cheiko and Carra de Vaux.

Abu 1-Feda (Isma'il b. 'Ali, king of Hamat in 743, died 749). Wrote Tarikh Mukhtasir. Ed. Constantinople, 2 vols. A.H. 1329. Text and Latin trans. by Reiske: Annales Moslemici, 5 vols, Copenhagen, A.D. 1 $789-1794$.

Also Taqwimu 1-Buldan, ed. with Lat. trans., Graevius, I650. Republished, ed. Hudson, Oxford, I7 12.

Fihrist. The Fihrist of Muhammad b. Ishaq an-Nadim.

Ed. Fluegel, Leipzig, 187 . Written circ. 378 (=A.D. 988), invaluable for earlier Shi'ite history. Many authors such as Akhu Muhsin, Ibn Razzam, etc., are known only by citations in the Fihrist.

Gregory Bar Hebraeus or Abu 1-Faraj.

d. A.D. 1286 . His great history was planned in three parts, of which part i. " the history of the dynasties" deals with political history. Syriac text edited by Bedjan, Paris, I 890 . The Arabic translation by the 
author is enriched with matter which does not occur in the Syriac, ed. Pococke, Oxford, 1663; Arabic text Beirut, 1890.

Al-Kairawani. Muhammad b. Ali r-Rayni al-Kairawani.

Ed. Pellisier et Rèmusat, Sciences hist. et géogr. vii.

Paris, 1845. (Explorat. scientifique de l'Algérie.)

Kamal ad-Din.

History of Aleppo. Ed. and trans. as "Regnum Saad aldawlae." G. W. Freytag, Bonn, 1820.

Ibn Khaldun, Wali ad-Din Abu Zayd Abdu r-Rahman ibn Khaldun.

d. 809. Ed. Bulaq, $1284(=1867)$ in 7 vols. Prolegomena, text and French tr. in vols. 16-2 I of Notices et extraits des manuscrits de la bib. nat.

De Slane, Histoire des Berbères, Alger, $185^{1-2}$.

Noel des Vergers, Hist. de l'Afrique, Paris, 1841.

Jornberg: Ibn Khaldunnarr de expedit. Francorum in terras Islamismo subjectas. Upsala. 1840. (Text and Latin trans.)

Ibn Khallikan. Shams ad-Din Abu 1-Abbas.

d. 68I. Wrote Wafiat ul-Aiyan (Biographical Dictionary), strongly anti-Fatimid. Ed. Wüstenfeld, Gottingen, 1835. Eng. Trans. (cited in references) by De Slane, $1835-40$.

Khandemir (Khwand Amir).

Persian. Ed. (with German tr.) Die Geschichte

Tabaristans, etc., St. Petersburg, 1850.

Abu 1-Mahasin.

d. 875. Ed. J. D. Carlyle, Maured Allatafet Jemaleddim. Cambridge, 1792 (very defective).

Annals, ed. T. G. J. Juynboll, Leiden, 186r.

Al-Makini.

d. 672. Ed. Erpenius, Historia Saracenica, Lugd. Batav, 1625 .

Maqrizi, Ahmah b. 'Ali b. 'Abdu 1-Qadir al-Maqrizi (dz. $845)$.

Chief authority for the history and antiquities of Cairo. Favourably disposed towards the Fatimid Khalifs from whom he claimed descent.

Ed. Bulaq, A.H. 1270. Portions translated in De Sacy's Chrestomathie. Part by Bouriant (but nothing relating to the Fatimids as yet reached in this translation. Pub. 1895, etc. in progress). Ed. Wiet, Cairo, 1911, etc. (a corrected text).

Wuestenfeld: Macrizi's Geschichte der Copten. (Text and trans.) 1845 . 
Nasir-i-Khusraw.

Sefer Nameh, Rélation du voyage de Nasir i Khosrau, ed. and tr. C. Schefer, Paris, I88I.

An-Nuwairi, Ahmad b. 'Abdu 1-Wahhab. (d. 733).

Only portions accessible, no full text published.

Dozy, Historia Abbadidarum, ii. 1846.

Dozy, Historia Siciliae, Arabice et Latine, 1790.

Hist. de la Sicilie, trad. par J. J. A. Caussin, Paris, Osama.

year $x(1802)$.

Derenbourg, Vie d'Ousâma, Paris, 1886.

(Contains Osama's own memoirs: invaluable for the reign of az-Zafir and the history immediately following.) al-Qalqashandi.

Al-Kalkashandi, tr. Wüstenfeld, Die Geographie, etc.

Gottingen, 1879 .

(B). Modern Writers.

De Goeje: Mémoires sur les Carmathes du Bahrain et les Fatimides. Leide, i 886.

Dozy: Essai sur 1-histoire de 1'Islamisme. Leide, I879.

Dussand, R. : Histoire et réligion des Nosairis. Paris, 1900. Guyard: Fragments relatifs á la doctrine des Ismaélis. Paris, 1874 .

Von Kremer: Kulturgeschichte des Orients unter den Chalifen. $1875-7$.

Lane Pooles: Story of Cairo. Lond., I906.

,, History of Egypt. Middle Ages. Lond. New ed. 1914.

Moslem Dynasties. I 894.

", Art of the Saracens in Egypt. 1886.

,, Coinage of Egypt A.H. 358-922. (Vol. ii. of Catal. of Brit. Mus. Oriental Coins). 1892.

Mann, J. : The Jews in Egypt and Palestine under the Fatimid Caliphs. Oxford, 1920.

Qatremere: Sur la dynastie des Khalifes Fatimites. (Journal asiat. for August, ${ }_{1} 836$. 3rd series, No. 2.)

Ravaisse : Essai sur l'histoire etc. d'aprés Makrizi.

Rivoira : Moslem architecture. Eng. trans. Oxford, 1918.

De Sacy: Exposé de la religion des Druzes. Paris, 1838 ( 2 vols.).

De Sacy: Chrestomathie (vols. i. and ii.).

Wuestenfeld: Geschichte d. Fatimiden Chalifen. Göttingen, $188 \mathrm{I}$.

(A series of extracts, not a connected history.)

Wuestenfeld : El-Macrizi's Abhandlung. 1847 .

Zaydam, G. : Umayyads and Abbasids. Lond., 1907. 


\section{INDEX}

$\mathbf{A}$

'Abbas, 229

-wazir, 230

Abdan, 45

'Abdullah, founder (or reformer) of Isma'ilite sect, 16, 17, 21, 32

'Abdullah b. Essaig, minister to the Aghlabids, 66

Abu'Abdullah, missionary in $\mathrm{N}$. Africa, 57 sqq.

一suspected, 69

-executed, $7 \mathbf{I}$

Abu Khatam's sect, 48

Abu Najah, the monk and minister of finance, 220

Abu Raqwa, Umayyad claimant in -invades Egypt 149 sqq.

N. Africa, 147 sqq.

-defeated, ${ }^{5} \mathbf{I}$

-death, ${ }^{152}$

Aghlabid dynasty in N. Africa, 59,247

Ahmad, son of Abdullah, 33

Ahmah, wazir to al-Hafiz, 222223

Al-Adid, 235

Al-Afdal, $216-220$

Al-Amir, Khalif, 218

-assassinated, 220-221

Al-'Aziz, Khalif, I 5 sqq.

-death, I 2 I-122

Aleppo, 175, 176, I95

Al-Fa'iz, Khalif, 233

Al-Hafiz, Khalif, 222

Al-Hakim, Khalif, 121, 123 sqq.

-peculiarities, 133

-mosques, $137-8$

-disappears, 185 sqq.

-reports that he is still alive, 188 'Ali, 4, 5

'Ali Allahi, 16

'Alid lines of descent, 5, 11

Al-Jarjarai, 193, 196

Al-Mahadiya founded, 77

Al-Mansur, Khalif, 90, 91

Al-Mo'izz, Khalif, 93 sqq.

-goes to Egypt, 109 -his rule in Egypt, 113

Al-Mustali, Khalif, 210 sqq.

Al-Mustansir, Khalif, 88

Al-Qa'im, Khalif, 88

Al-Y̌Yzuri, 196, 197, 198, 200, 203

Amalric, 239-242

Anustakin, 191-196

Arab race, 1

Armenians in Egypt, 206, 223-224

As-Salih, 233, 235-236

Assassins, sect of, 209, 210 sqq., 244-245

Az-Zafir, Khalif, 227

Az-Zahir, Khalif, 189

\section{B}

Babists, ${ }^{5} 5$

Badr the Armenian, 206, 208

Bahrayn taken by the Qarmatians, 49-50

Baldwin, 218-219

Barjawan, 124, 126, 130

- assassinated, I3 I

Barqa taken by Abu Raqwa, 148 149

Batinite doctrines, $7,12,176$

Berbers, 55-56, 7t sqq.

B. Qorra, $147-148$

Buraniyya sect, 48

Byzantium, treaty with, 191

\section{C}

Cairo founded, 102 sqq., 114

Christians, 2, 116, 141, 143-145, $155^{-1} 5^{8}, 170,1799^{-1} 80$, $197^{-198}$, 226

-allowed to emigrate, 171

Cluniac movement, 252-254

" Companions" cursed, 142

-cursing stopped, 154, 169

Crusades, 216-218, 224, 236, 238 $239,241,255$ 
D

Da'i or'missionary of Shi'ite sect, 6,7

- arguments used by Isma'ilian da'i, 21 sqq.

-Chief Da'i, 135

Darazi, Persian teacher who visited Egvpt, 176

Daylamites, 83

Daysan, 18

Dirgham, 236, 238

Druses, 43, 178-179, I87, 244

\section{E}

Egypt attacked, 78, 94

-Shi'ites in, 79

- disorder in Egypt, 97-98

-invaded by the Fatimids, 99 sqq.

\section{F}

Fadl, general under al-Hakim, $149,15^{2-1} 53$

Famine in Esypt, 190, 204-205

Fatimid claims, 34 sqq. ; cf. "Alid lines of descent

-claims ridiculed, 116

-manifesto against, 166

Fatimid architecture, I 06

-decline of Fatimids, 254

- end of Fatimid rule, $243-245$

Forbidden vegetables, $141-142,164$

Fustat, 102

-fired by al-Hakim, 183

\section{$\mathrm{H}$}

Haftakin, I I I sqq.

-prisoner, I 19

Hamdan, 39, 40, 43

Hamza, $178,179,181$

Hasan al Akhram, iz 8

Hasan b. Mufarraj revolts, 163

Hasan-i-Sabbah visits Egypt, 208 sqq., 2 I 2

Hasan Qarmatian leader, 47

Hashimites, 5

$\mathrm{Hijaz}$, recognition of Fatimids in, 202-203

“House of Wisdom," 139-140

Husayn Ahwazi, 39

Husayn b. Jawhar, I3I, 132, 153160
Ibn al-Muqaffa', 18

Ibn 'Ammar, 124

-downfall, 126-127

Ibn Hawshab, 5I sqq.

Ibn Killis the Jew, 99, I14, I 20

Ibn Nestorius, 120

Ibn Sallar wazir, 227

-revolts, 227-229

-murdered, 229-230

Idrisids, 76,99

Ikhshids, $81,83,93,107$

Ikhwanu s-Safa, 139

Isma'il, 9

Isma'ilian sect, I 2 sqq., 29

-doctrine, $257-25^{8}$

-offshoots, 212,260 sqq.

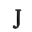

Ja'far as-Sadiq, I6, 37, 45, I6I, 257

Jawhar, 98

-invades Egypt, 99 sqq.

Jerusalem, church of the Resurrection destroyed, I 57

- city taken by the Turks, 207

-by the Crusaders, 2 I 6

-kingdom of, 216, 255

"Jewish legend," 34, 47, 68

Jews, 2, $155^{-160, ~ 170, ~ 179-1 ~} 80$

\section{K}

Kafur, 93 sqq.

-a patron of literature, 95

Kahira, cf. Cairo

Kairawan, $61,64,76,85$

Khalifs of, 74 sqq.

Kasam, 47

Katama tribe, 57

Kaysanite sect, 5

Khalif, title of, 3

Kharijites, 56,75

-revolt of, $88-89$

" King " as title of the wazir, 224

L

Legitimist ideas of the Persians, $3,14,15$

Licence issued by ad-Hakim to non-Muslims, I 45 
Madina officials sent to remove articles from, I6 I

Maghrab, 55

Mahmud of Ghazna, I68, 249-250

Mani, 19

Mansuri sect, 7

Marcion, 19

Maymun, 18,20

Muslim expansion, 2

\section{$\mathrm{N}$}

Nasir ad-Dawla, 204-205

Nasir ad-Din, 229

- murders az-Zafir, 230-232

Nasir-i-Khusraw visits Egypt, 198 sqq., 209

Nizar's revolt, 2 I 1-212

Vorth Africa, $5^{2}$ sqq.

- deserts the Fatimids, 200-201

Nuwayri's account of oath taken by Isma'ilis, 30

\section{$\mathrm{O}$}

Okayl Arabs revolt, 164

Oman resists the Qarmatians, $5^{\circ}$ Osama, 225 sqq., 230

\section{$\mathrm{P}$}

Patriarch imprisoned by al-Hakim, ${ }_{1} 5^{8}$

-released, I $80-18$ I

Persians, 3, 7

Princess Royal al-Hakim's sister, I $82-184$, i 89

Palestine and Syria lost to the Fatimids, 219

\section{Q}

Qadi, office of, 134

R

Raq̨ada, 64

-taken by Abu 'Abdullah, 67, 69

Rudwan, 224-225
Sab'iya, Isma'ilian sect, 10, 17

-grades, 21 sqq.

Saladin, $238-239,243,256$

Saljuq Turks, 201, 207, 215, 219, 25I, 254

Seveners," cf. Sab“iya

Shawar, 236-243

Shi'ites, 4, 16

-sects, 6; cf. Isma'ilians

-claims, 42

Shirkub, 236, 238, 239, 24I

Sicily revolts, 77

Syria, 102, 117, 126-127, 129, $136,163,174,175,191-195,234$

- lost to the Fatimids, 219

\section{$\mathrm{T}$}

Tekin, 79 sqq.

Transmigration, 14

Tripoli, 77

Turks; cf. Saljuq

"Twelvers," io

\section{U}

'Ubayd Allah, 33, 6r sqq.

- journey to N. Africa, 62

-imprisoned, 62

-liberated, 67 sqq.

W

Wine, laws against, 165

\section{Y}

Yahya's sect, 48

Yemen, Isma'ilians in, $\mathbf{5}$ sqq.

Yusuf, 184

\section{Z}

Zaqrima, 46

Ziadat Allah, 6o, 62 sqq. 







\title{
PLEASE DO NOT REMOVE CARDS OR SLIPS FROM THIS POCKET
}

\author{
UNIVERSITY OF TORONTO LIBRARY
}




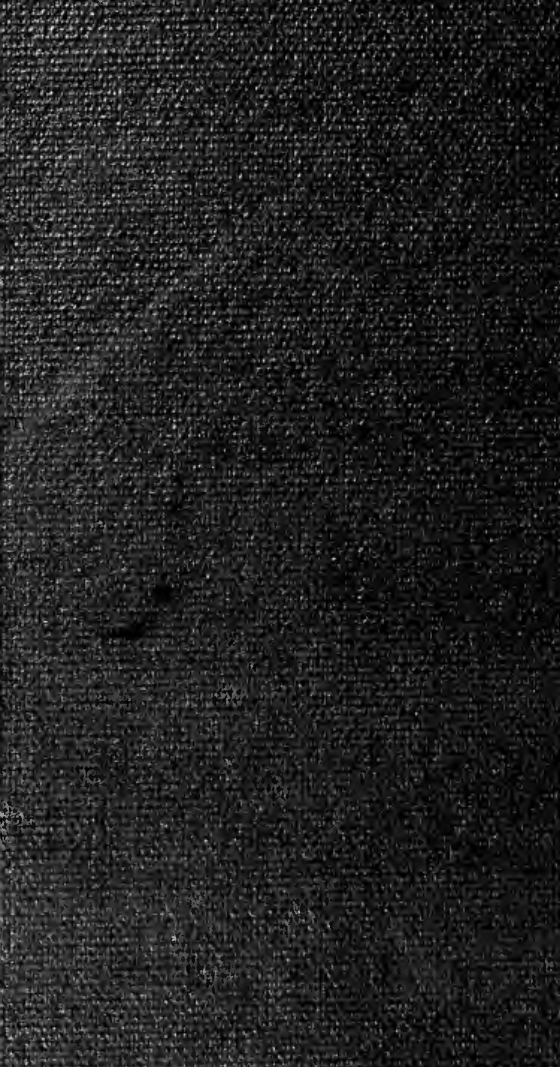

15.

15.

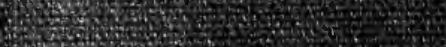
5.

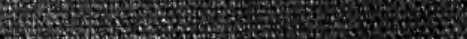

30.0.

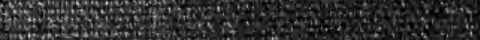

T25050

(2)

150.

1.5.

H.

25t Het Non

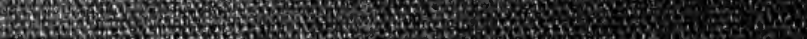

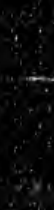

